\title{
ANÁLISE DE RUPTURA DE TALUDE EM SOLO NÃO SATURADO
}

\author{
José Antonio Cancino Calle
}

Dissertação apresentada à Escola de Engenharia de São Carlos da Universidade de São Paulo, como parte dos requisitos para obtenção do título de Mestre em Geotecnia.

ORIENTADOR: Prof. Dr. Orencio Monje Vilar

São Carlos

2000 


\section{FOLHA DE APROVAÇÃO}

Autor:

Título:
Dissertação defendida e aprovada em 1
pela comissão julgadora:

(Assinatura)
(Nome/Instituição)

\section{(Assinatura)}

(Nome/Instituição)

(Assinatura)

(Nome/Instituição)

Coordenador da Área

Presidente da CPG 
Aos meus pais,

José Cancino e Luz Calle 


\section{AGRADECIMENTOS}

Pelas valiosas contribuições técnicas e o auxilio fornecido para a elaboração deste trabalho, expresso minha profunda gratidão aos seguintes profissionais:

Ao Prof. Dr. Orencio Monje Vilar;

Ao Prof. Dr. Carlos Angelo Cintra;

À Coordenadoria de Aperfeiçoamento de Pessoal de Nível Superior - CAPES;

A todos os docentes do Departamento de Geotecnia;

Ao Engenheiro Dr. Herivelto M. dos Santos;

Aos técnicos do Departamento de Geotecnia, Srs. José Luís Guerra e Oscar dos Santos;

Aos Profs. Calixtro Yanqui Murillo e Juan Barahona Meza - Escuela profesional de Ingeniería Civil, Universidad Nacional de San Agustín de Arequipa del Perú;

A meu irmão Carlos Tapia Calle;

Aos colegas e funcionários deste Departamento.

Pela oportunidade de realizar o curso de Pós Graduação, meu profundo reconhecimento à comissão da Pós Graduação da Escola de Engenharia de São Carlos - USP 


\section{SUMÁRIO}

LISTA DE FIGURAS

LISTA DE TABELAS $v i$

LISTA DE ABREVIATURAS E SIGLAS viii

LISTA DE SÍMBOLOS ix

RESUMO xii

ABSTRACT xiii

1 INTRODUÇÃO 1

\section{REVISÃO BIBLIOGRÁFICA}

2.1 SOLOS NÃO SATURADOS 4

2.1.1 POTENCIAL DA ÁGUA DO SOLO _ 5

2.1.1.1 POTENCIAL MATRICIAL $\left(\psi_{\mathrm{M}}\right) \_6$

2.1.1.2 POTENCIAL OSMÓTICO $\left(\psi_{0}\right)$ _ 6

2.1.1.3 POTENCIAL GRAVITACIONAL $\left(\psi_{\mathrm{Z}}\right) \_6$

2.1.1.4 POTENCIAL PNEUMÁTICO $\left(\psi_{\mathrm{pn}}\right) \longrightarrow 7$

2.1.1.5 POTENCIAL TOTAL__ 7

2.1.2 CURVA DE RETENÇÃO DA ÁGUA DO SOLO___ 9

2.1.3 RELAÇÕES EMPÍRICAS PARA DEFINIR A CURVA DE RETENÇÃO DE ÁGUA NO SOLO 13

2.1.4 MEDIÇÃO DA SUCÇÃO DO SOLO __ 14

2.1.4.1 MEDIDA DA SUCÇÃO TOTAL __ 14

2.1.4.2 MEDIDA DA SUCÇÃO MATRICIAL__ 17

2.1.5 CONDUTIVIDADE HIDRÁULICA _ 19

2.1.5.1 CONDUTIVIDADE HIDRÁULICA SATURADA_ 20

2.1.5.2 CONDUTIVIDADE HIDRÁULICA NÃO SATURADA ___ 21

2.1.5.3 COEFICIENTE DE CONDUTIVIDADE HIDRÁULICA SATURADA E NÃO SATURADA A PARTIR DE TÉCNICAS DE ENSAIO DE CAMPO 23 
2.1.6 RESISTÊNCIA AO CISALHAMENTO EM SOLO NÃO SATURADO _ 30

2.1.6.1 INTRODUÇÃO__ 30

2.1.6.2 RESISTÊNCIA AO CISALHAMENTO EM SOLO NÃO SATURADO__ 30

2.1.6.3 ENSAIO DE COMPRESSÃO TRIAXIAL COM CONTROLE DE SUCÇÃO MATRICIAL 36

2.2 ENGENHARIA GEOTÉCNICA EM SOLOS RESIDUAIS 38

2.2.1 INTRODUÇÃO 38

2.2.2 SOLO RESIDUAL 39

2.2.2.1 DEFINIÇÃO 39

2.2.2.2 CARACTERÍSTICAS ESPECIAIS DOS SOLOS RESIDUAIS 40

2.2.2.3 PERFIL DE INTEMPERIZAÇÃO 40

2.2.3 ESTABILIDADE DE TALUDES EM SOLO RESIDUAL 43

2.2.3.1 PRECIPITAÇÃO INTENSA E PROLONGADA 44

2.2.3.2 INTERFERÊNCIA HUMANA 47

2.2.4 RELAÇÃO ENTRE PRECIPITAÇÃO E ESCORREGAMENTO 49

2.2.5 ANÁLISE DE ESTABILIDADE DE TALUDES 50

2.2.5.1 ANÁLISE DE TALUDES POR MÉTODOS TRADICIONAIS__ 50

2.2.5.2 MÉTODOS DE PROJETO SEMI EMPÍRICO __ 52

2.2.5.3 MÉTODOS POR AVALIAÇÃO DO TERRENO__ 53

2.2.6 INSTRUMENTAÇÃO EM TALUDES__ 54

2.3 RETRO-ANÁLISE _ 57

2.3.1 TÉCNICAS DE RETRO-ANÁLISE _ 59

2.3.1.1 MÉTODOS ANALÍTICOS _ 59

2.3.1.2 MÉTODOS OBSERVACIONAIS___ 63

3 MATERIAIS E MÉTODOS___ 68

3.1 CARACTERÍSTICAS GERAIS DO TALUDE ESTUDADO __ 68

3.2 RECONHECIMENTO GEOTECNICO __ 71

3.3 COLETA DE AMOSTRAS DEFORMADAS E INDEFORMADAS EM CAMPO___ 72

3.4 ENSAIOS DE CARACTERIZAÇÃO___ 72

3.5 OBTENÇÃO DA CURVA DE RETENÇÃO DA ÁGUA DO SOLO__ 72

3.6 CONTROLE DE SUCÇÃO MATRICIAL EM CAMPO ___ 73

3.7 OBTENÇÃO DA CURVA DE CONDUTIVIDADE HIDRÁULICA NÃO SATURADA _ 73 
3.8 ENSAIOS DE COMPRESSÃO TRIAXIAL 76

3.8.1 ENSAIOS TRIAXIAIS CONVENCIONAIS_ 76

3.8.2 ENSAIOS TRIAXIAIS COM CONTROLE DE SUCÇÃO MATRICIAL__ 80

3.9 ANÁLISE DE RUPTURA___ 82

$4 \quad$ RESULTADOS OBTIDOS___ 86

4.1 RECONHECIMENTO GEOTÉCNICO ___ 86

4.2 ENSAIOS DE CARACTERIZAÇÃO____ 87

4.3 CURVA DE RETENÇÃO DA ÁGUA DO SOLO ___ 88

4.4 MEDIDA DE SUCÇÃO MATRICIAL NO CAMPO __ 90

4.5 CONDUTIVIDADE HIDRÁULICA SATURADA _ 91

4.6 CURVA DE CONDUTIVIDADE HIDRÁULICA NÃO SATURADA ___ 91

4.7 ENSAIOS DE COMPRESSÃO TRIAXIAL__ 93

4.7.1 ENSAIOS TRIAXIAIS CONVENCIONAIS.___ 93

4.7.2 ENSAIOS TRIAXIAIS COM CONTROLE DE SUCÇÃO MATRICIAL__ 98

5 ANÁLISE DE RUPTURA 102

5.1 PERFIL DE SUCÇÃO MATRICIAL INICIAL “IN SITU” _ 102

5.2 ANÁLISE DE ESTABILIDADE PARA AS CONDIÇÕES INICIAIS ___ 103

5.3 DEFINIÇÃO DA SUPERFÍCIE DE RUPTURA CONSIDERANDO-SE A FENDA DE TRAÇÃO__ 104

5.4 INFLUÊNCIA DA PRECIPITAÇÃO NO AVANÇO DA FRENTE DE UMEDECIMENTO. 105

5.5 FATORES DE SEGURANÇA OBTIDOS COM OS PARÂMETROS DOS ENSAIOS CD E UU. 112

5.6 ANÁLISE DE RUPTURA___ 122

5.7 ANÁLISE DE RUPTURA SEGUNDO OS ÁBACOS DE HOEK (1972) ___ 124

5.8 VARIAÇÃO DO FATOR DE SEGURANÇA COM O TEMPO DE PRECIPITAÇÃO, VÁLIDO PARA TALUDE HOMOGÊNEO COM i=63,9e H=15,22m 125

6 CONCLUSÕES__ 127

ANEXOS 129

ANEXO A - SONDAGENS S1 e S2. 130 
ANEXO B - ENSAIOS COM PAPEL FILTRO.

ANEXO C - ENSAIOS COM A CÂMARA DE PRESSÃO. 137

ANEXO D - PLANILHAS DO ENSAIO DE CAMPO COM O PERMEÂMETRO DE GUELPH. 139

ANEXO E - CARACTERÍSTICAS DOS CORPOS DE PROVA DOS ENSAIOS TRIAXIAIS REALIZADOS.

142 


\section{LISTA DE FIGURAS}

\section{CAPÍTULO II}

FIGURA 2.1 - Esquema ilustrativo da definição de potencial total da água no solo.

FIGURA 2.2- Água de um solo não saturado sujeita a capilaridade e absorção que combinadas produzem um potencial matricial (Hillel, 1971).

FIGURA 2.3- Esquema ilustrativo da definição de sucção: Corresponde a $u_{a}$ - $u_{w}$ de sorte a não haver fluxo através da membrana semi-permeável. Comumente $u_{a}=$ Patm 8

FIGURA 2.4-Representação dos conceitos de sucção matricial, osmótico e total. 8

FIGURA 2.5- Curva característica de solos argilosos e arenosos (Hillel, 1971). 9

FIGURA 2.6- Curvas características por umedecimento e secagem (Hillel, 1971). 10

FIGURA 2.7 - Efeito da estrutura do solo na curva de retenção. 11

FIGURA 2.8- Curvas características obtidas para diferentes tipos de solos (Koorevar et al., 1983)... 11

FIGURA 2.9- Efeito "Ink Bottle”. 12

FIGURA 2.10- Caracterização da curva de retenção segundo Fredlund \& Xing (1994).

FIGURA 2.11- Esquema de um Psicrômetro. 15

FIGURA 2.12- Funil de placa porosa (Reichardt, 1985). 17

FIGURA 2.13-Câmara de pressão (Reichardt, 1985). 18

FIGURA 2.14- Esquema do Permeâmetro Guelph. 24

FIGURA 2.15- Gráfico do fator de forma " $C^{\prime \prime}$. 26

FIGURA 2.16- Bulbo saturado e não saturado ao redor do furo de sondagem durante o ensaio a carga constante. 26

FIGURA 2.17- Representação gráfica da expressão de Fredlund et al. (1978). 32

FIGURA 2.18- Variação da coesão e do angulo de atrito interno em função da sucção matricial (Delage et al., 1987). 33 
FIGURA 2.19- a)Resistência ao cisalhamento $x$ tensão normal para diferentes valores de sucção matricial b)Resistência ao cisalhamento $x$ sucção matricial para diferentes valores de tensão normal, Escario \& Saez (1986)

FIGURA 2.20- Variações de c e ф com a sucção para dois solos distintos. Escario \& Jucá (1989)..... 35

FIGURA 2.21- Perfil de intemperização típica para rocha ígnea intrusiva ou metamórfica. Deere \& Patton, 1971. 42

FIGURA 2.22- Avanço da frente de umedecimento causada pela infiltração da água (Lumb, 1975)... 45

FIGURA 2.23- Efeito da infiltração da água de chuva (acima) e duração da precipitação (abaixo) versus o fator de segurança (Boonsinsuk \& Yong, 1982).

FIGURA 2.24- a) Seção do bloco mostrando a geologia de Bethlehem, b) medidas de ensaios de Vane em siltito intemperizado (Blight et al, 1970).

FIGURA 2.26- Correlação entre a altura do talude e angulo para xisto argiloso, Lane (1961)........... 54

FIGURA 2.27 - Instrumentação de um talude em solo residual Singapura, Leong et al (1998)........... 56

FIGURA 2.28- Relação entre análise comum e retro-análise (Sakurai, 1993).................................... 57

FIGURA 2.29- comparação entre a) Analise comum e b) Retro-análise (Sakurai, 1993)..................... 57

FIGURA 2.30 - Retro-análise para solos saturados ou secos.

FIGURA 2.31- Curvas para projeto de taludes, com fator de segurança igual a 1,10 em ardósias e quartzitos (Fonte: Rana \& Bullock, 1969).

FIGURA 2.32- Curvas médias representativas de inclinações versus alturas de taludes (Fonte: Lutton, 1970).

FIGURA 2.33- Gráfico de variação de inclinação versus altura de taludes (Barton, 1971).

FIGURA 2.34- Ábaco de ruptura circular (Fonte: Hoek, 1972).

FIGURA 2.35- Funções (X,Y) para acompanhamento do ábaco de ruptura circular (Fonte: Hoek, 1972).

\section{CAPÍTULO III}

FIGURA 3.1 - Elementos do talude em análise: a) Vista tridimensional; b) Perfil do escorregamento.69

FIGURA 3.2- Vista do talude escorregado. 70

FIGURA 3.3- Vista do escorregamento panorâmico. 70

FIGURA 3.4- Detalhe da fenda encontrada em campo. 71

FIGURA 3.5- Detalhe de um escorregamento superficial. 71

FIGURA 3.6 - Câmaras de pressão usadas para determinar a curva de retenção. 73 
FIGURA 3.7 - Ensaios realizados com o Permeâmetro Guelph no local AI1.

FIGURA 3.8- Ponteira de água do Permeâmetro Guelph a) Permeâmetro sem saída de água; b) Permeâmetro com saída de água.

FIGURA 3.9 - Ensaio de compressão triaxial convencional.

FIGURA 3.10 - Ensaio de compressão triaxial com a câmara de Bishop Wesley (GDS). 78

FIGURA 3.11 - Atuadores de pressão/volume utilizados na realização de ensaios do tipo tensão controlada. 79

FIGURA 3.12 - Representação esquemática da prensa Bishop Wesley utilizada. 79

FIGURA 3.13- Prensa triaxial tipo Bishop Wesley utilizada para a realização de ensaios com controle de sucção matricial.

FIGURA 3.14 - Forças atuando numa fatia de uma massa escorregada.

\section{CAPÍTULO IV}

FIGURA 4.1 - Perfil provável do solo no talude.

FIGURA 4.2 - Limites de consistência e umidade da sondagem S1.

FIGURA 4.3-Curva de retenção local de amostragem AII.

FIGURA 4.4 - Curva de retenção local de amostragem AI2.

FIGURA 4.5 - Curva de retenção local de amostragem AI3.

FIGURA 4.6 - Leituras de sucção matricial nos tensiômetros 1 e 2, período 1999/2000. 90

FIGURA 4.7 - Função Condutividade Hidráulica não Saturada $(\alpha=0.014)$. 92

FIGURA 4.8 - Curvas tensão - deformação e variação volumétrica - deformação (topo-AIl).

FIGURA 4.9 - Curvas tensão - deformação e variação volumétrica - deformação (base-AI2). 94

FIGURA 4.10 - Envoltórias de resistência dos ensaios CD para as amostras do topo e base respectivamente.

FIGURA 4.11 - Curvas tensão - deformação do ensaio não drenados (UU) na umidade natural. ....... 96

FIGURA 4.12- Envoltórias de resistência dos ensaios UU para amostras do topo e base respectivamente.

FIGURA 4.13 - Diagramas tensão-deformação para sucções matriciais de 50 e $100 \mathrm{kPa}$. 98

FIGURA 4.14 - Diagrama tensão-deformação para sucções matriciais de 30, 75, 150 e 300kPa..... 99

FIGURA 4.15 - Envoltórias de resistência não saturada para sucções de 50 e $100 \mathrm{kPa}$. 99 
FIGURA 4.16 - Envoltória de resistência não saturada com controle de sucção matricial, círculos de

Mohr. 100

FIGURA 4.17- Envoltória de resistência não saturada com controle de sucção matricial. 101

CAPÍTULO V

FIGURA 5.1 - Perfil de sucção matricial inicial adotado. 103

FIGURA 5.2 - Fator de segurança em condições iniciais sem consideração da fenda. 104

FIGURA 5.3 - Definição da superfície de ruptura considerando fenda de tração. 105

FIGURA 5.4 - Variação da frente de umedecimento ocasionada por uma precipitação de 20mm/h. . 106

FIGURA 5.5 - Variação da frente de umedecimento ocasionada por uma precipitação de 70mm/h. . 107

FIGURA 5.6 - Sucção no solo em kPa após 3 h de uma precipitação de $20 \mathrm{~mm} / \mathrm{h}$. 108

FIGURA 5.7 - Sucção no solo em kPa após $25 \mathrm{~h}$ de uma precipitação de $20 \mathrm{~mm} / \mathrm{h}$ 109

FIGURA 5.8 - Sucção no solo em kPa após 3 h de uma precipitação de $70 \mathrm{~mm} / \mathrm{h}$. 110

FIGURA 5.9 - Sucção no solo em kPa após $15 \mathrm{~h}$ de uma precipitação de $70 \mathrm{~mm} / \mathrm{h}$. 111

FIGURA 5.10 - Superfície de ruptura para o caso b-1. 113

FIGURA 5.11 - Superfície de ruptura para o caso b-2. 114

FIGURA 5.12 - Superfície de ruptura para o caso b-3...... 114

FIGURA 5.13 - Superfície de ruptura para o caso b-4.............................................................. 115

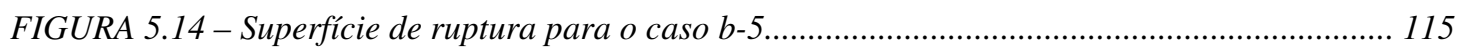

FIGURA 5.15 - Superfície de ruptura para o caso b-6................................................................. 116

FIGURA 5.16 - Superfície de ruptura para o caso b-7................................................................... 116

FIGURA 5.17 - Perfil do talude considerando-se os dois solos encontrados na sondagem. ............... 117

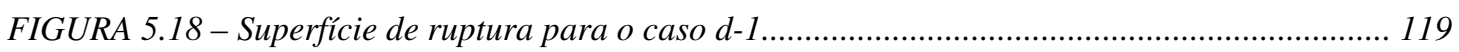

FIGURA 5.19 - Superficie de ruptura para o caso d-2.............................................................. 119

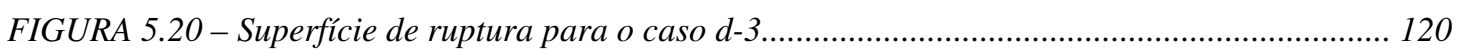

FIGURA 5.21 - Superfície de ruptura para o caso d-4............................................................... 120

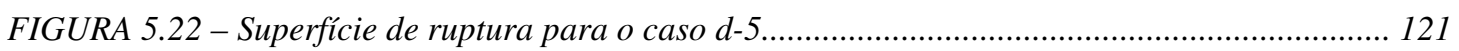

FIGURA 5.23 - Superficie de ruptura para o caso d-6................................................................. 121

FIGURA 5.24 - Superficie de ruptura para o caso d-7.................................................................... 122 
FIGURA 5.25 - Retroanálise considerando-se uma precipitação de 20mm/h e o FS=1, para o talude com $i=63,9^{\circ}$ e $H=15,2 m$ 123

FIGURA 5.26 - Retroanálise considerando-se uma precipitação de 70mm/h e o FS=1, para o talude com $i=63,9^{\circ}$ e $H=15,2 m$ 124

FIGURA 5.27 - Retro-análise segundo ábacos de Hoek(1972). 125

FIGURA 5.28 - Variação do fator de segurança com o tempo de precipitação para $\phi^{b}=20$ e precipitação de $20 \mathrm{~mm} / \mathrm{h}$. 126

FIGURA 5.29 - Variação do fator de segurança com o tempo de precipitação para $\phi \phi^{b}=20$ e precipitação de $70 \mathrm{~mm} / \mathrm{h}$. 


\section{LISTA DE TABELAS}

CAPÍTULO II

TABELA 2.1 - Correlações para determinação da sucção matricial com o método do papel filtro....... 16

TABELA 2.2- Métodos para a medida de suç̧ão (Vilar, 1997).

TABELA 2.3- tipos de Permeâmetros (Daniel \& Stephen, 1994).

TABELA 2.4 - Relações empíricas para determinação da condutividade hidráulica não saturada.......22

TABELA 2.5 - Parâmetros $\alpha$ sugeridos por ELRICK et al (1989).

TABELA 2.6- Características das pedras porosas usadas por Bishop et al (1960).

TABELA 2.7- Ensaios Triaxiais para solos não saturados.

CAPÍTULO III

TABELA 3.1 - Condições do ensaio CD, saturado por contra pressão 77

TABELA 3.2 - Condições do ensaio UU, rápido, em umidade natural. .77

TABELA 3.3- Condições de ensaio dos corpos de prova em ensaios triaxiais com controle de sucção matricial.

\section{CAPÍTULO IV}

TABELA 4.1 - Ensaios de caracterização dos blocos indeformados coletados do topo e da base do talude.

TABELA 4.2 - Parâmetros da equação de Van Genutchen (1980).

TABELA 4.3 - Quadro comparativo da sucção medida por tensiômetro e papel filtro.

TABELA 4.4 - Características do corpo de prova do ensaio de permeabilidade. 91

TABELA 4.5 - Parâmetros da condutividade hidráulica não saturada do topo do talude. 92

TABELA 4.6 - Ensaios triaxiais com controle de sucção matricial. 100 


\section{CAPÍTULO V}

TABELA 5.1 - Fatores de segurança considerando-se a superfície de ruptura assumida para o talude formado por um solo.

TABELA 5.2 - Fatores de segurança considerando-se a superfície de ruptura fornecida para um único solo.

TABELA 5.3 - Fatores de segurança considerando-se a superfície de ruptura assumida para dois solos.. 118

TABELA 5.4 - Fatores de segurança considerando-se a superfície de ruptura fornecida para dois solos.

ANEXOS

TABELA B1 - Ensaio de papel filtro, local AI1.

TABELA B2 - Ensaio de papel filtro, local AI2.

TABELA B3 - Ensaio de papel filtro, local AI3

TABELA C1 - Condições iniciais antes do ensaio com a câmara de pressão, local AIl. 138

TABELA C2 - Resultados obtidos, local AI1. 138

TABELA C3 - Condições iniciais antes do ensaio com a câmara de pressão, local AI3. 138

TABELA C4 - Resultados obtidos, local AI3. 138 


\section{LISTA DE ABREVIATURAS E SIGLAS}

S - sondagem

AD - amostra deformada

AI - amostra indeformada

$\mathrm{T}$ - tensiômetro

CP - câmara de pressão ou corpo de prova nos anexos

FS - fator de segurança

$\mathrm{P}_{\mathrm{atm}}{ }^{-}$pressão atmosférica

SPT - Standard Penetration Test

NBR - Norma Brasileira Registrada

ASTM American Society for Testing and Materials

ABGE Associação Brasileira de Geologia de Engenharia

IPT - Instituto de Pesquisa Tecnológicas

DAEE Departamento de Águas e Energia Elétrica

IBGE Instituto Brasileiro de Geografia e Estatística 


\section{LISTA DE SÍMBOLOS}

$\alpha$ - parâmetro de ajuste da curva ou sorção no cálculo da curva de retenção e condutividade hidráulica não saturada, e também, ângulo entre a tangente ao centro da base de cada fatia e a horizontal quando utilizado o método de Bishop na determinação da estabilidade de taludes

$\beta$ - $\quad$ largura da fatia

$\in$ - função erro

$\lambda$ - parâmetro de ajuste, depende do tipo de solo

$\psi$ - potencial total ou sucção total

$\psi_{\mathrm{a}}$ - $\quad$ sucção matricial que corresponde à entrada de ar

$\psi_{M^{-}} \quad$ potencial matricial ou sucção matricial equivalente a sucção total $(\psi)$ no presente trabalho

$\psi_{\mathrm{O}}$ - $\quad$ potencial osmótico ou sucção osmótica

$\psi_{\mathrm{P}}$ - $\quad$ potencial de pressão

$\psi_{\mathrm{pn}}{ }^{-} \quad$ potencial pneumático

$\psi_{\mathrm{r}}$ - $\quad$ sucção matricial que corresponde à umidade volumétrica residual

$\psi_{\text {aev }}$ - sucção matricial no "air entry"

$\psi_{1}$ - $\quad$ sucção matricial residual

$\theta^{\prime}{ }_{s}$ - umidade volumétrica de saturação para curva obtida pelo processo de secagem

$\theta_{\mathrm{r}}-\quad$ umidade volumétrica residual

$\theta_{\mathrm{s}}$ - umidade volumétrica de saturação para curva obtida pelo processo de umedecimento

$\sigma$ - $\quad$ tensão normal

$\phi$ - $\quad$ ângulo de atrito do solo

$\phi^{\mathrm{b}}$ - $\quad$ ângulo de atrito do solo em relação a sucção

$\phi_{\mathrm{gm}}-\quad$ potencial matricial de fluxo

$\rho_{\mathrm{w}}$ - massa específica de água

$\rho$ - $\quad$ massa específica do solo

$\rho_{\mathrm{s}}$ - massa específica de sólidos 
$\rho_{\mathrm{d}}-\quad$ massa específica seca

$\tau$ - $\quad$ resistência ao cisalhamento

$\psi_{Z^{-}} \quad$ potencial gravitacional

Х - $\quad$ parâmetro que depende do grau de saturação

$\mathrm{a}, \mathrm{b}$ - constantes

a - raio no furo do solo no ensaio com o permeâmetro de Guelph ou distância perpendicular da força externa de água " $\mathrm{A}$ " ao centro de momentos quando utilizado o método de Bishop.

$a_{\mathrm{r}}$ - valor aproximado da sucção matricial de entrada de ar

C, c - fator de forma na determinação da condutividade hidráulica não saturada e coesão total nos ensaios de compressão triaxial

$c^{\prime}$ - $\quad$ coesão efetiva

e - $\quad 2,71828$

E - força normal horizontal entre fatias

f - $\quad$ braço da força normal " $N$ " ao centro de momentos ou centro de rotação

h, $\mathrm{H}$ - altura de carga

$\mathrm{H}$ - $\quad$ altura do talude

$\mathrm{h}$ - $\quad$ espessura do avanço da infiltração da água de chuva num tempo qualquer, quando utilizada a fórmula de Lumb(1975)

$\Delta \mathrm{h}$ - $\quad$ perda de carga

i - inclinação do talude

K - coeficiente de condutividade hidráulica

$\mathrm{K}_{\mathrm{s}}$ - $\quad$ coeficiente de condutividade hidráulica saturada

$K(\theta)$ - coeficiente de condutividade hidráulica não saturada

$\mathrm{K}_{\mathrm{r}}$ - $\quad$ coeficiente de condutividade relativa

$\mathrm{K}_{1}$ - coeficiente de condutividade hidráulica para $\psi=\psi_{1}$

L - comprimento do solo

n,m - parâmetros de ajuste na determinação da condutividade hidráulica e curva de retenção

$\mathrm{n}$ - $\quad$ porosidade

$\mathrm{N}$ - força normal total na base da fatia

Q - vazão

Pe - Pressão externa equivalente a pressão atmosférica

pF - $\quad$ logaritmo de pressão expresso em centímetros de água

$\mathrm{R}, \mathrm{r}$ - constante universal dos gases, $8,31432 \mathrm{~J} / \mathrm{molK}$ ou raio da superfície de ruptura circular quando utilizado o método de Bishop. 
$\mathrm{S}_{\mathrm{r}}$ - $\quad$ grau de saturação

$\mathrm{S}_{\mathrm{ru}}$ - grau de saturação residual

$\mathrm{S}_{\mathrm{e}}$ - $\quad$ Saturação efetiva

$\mathrm{S}_{\mathrm{f}}, \mathrm{S}_{\mathrm{o}}$ - Graus de saturação final e inicial

$\mathrm{S}_{\mathrm{rs}}$ - $\quad$ saturação de campo

$\mathrm{S}_{\mathrm{m}}$ - força de cisalhamento mobilizada

$\mathrm{T}$ - temperatura

T2, T6, T10, T11, T12, T13 - nome adotado para os corpos de prova utilizados nos ensaios realizados com a câmara de pressão

$\mathrm{t}$ - $\quad$ tempo

$\mathrm{u}_{\mathrm{A}}{ }^{-} \quad$ pressão no ponto $\mathrm{A}$

$\mathrm{u}_{\mathrm{a}}$ - pressão de ar

$\mathrm{u}_{\mathrm{B}}$ - $\quad$ pressão no ponto $\mathrm{B}$

$\mathrm{u}_{\mathrm{v}}$ - pressão parcial do vapor de água dos poros

$\mathrm{u}_{\mathrm{vo}}$ - pressão de saturação do vapor de água a mesma temperatura de $\mathrm{u}_{\mathrm{v}}$

$\mathrm{u}_{\mathrm{w}}$ - pressão de água

$\mathrm{u}_{\mathrm{i}}$ - $\quad$ quantidade calculada

$\mathrm{u}_{\mathrm{i}}{ }^{*}$ - $\quad$ quantidade medida

v - velocidade de descarga

$\mathrm{V}$ - volume total

$\mathrm{V}_{\mathrm{w}}-\quad$ volume de água

$\mathrm{w}_{\mathrm{p}}$ - umidade do papel filtro

$\mathrm{W}_{\mathrm{v}}$ - massa molecular do vapor de água, $18,016 \mathrm{~kg} / \mathrm{molK}$

$\mathrm{W}_{\mathrm{r}}-\quad$ teor de umidade residual

$\mathrm{W}_{\mathrm{s}}$ - teor de umidade saturado

$\mathrm{w}_{\mathrm{o}}$ - $\quad$ teor de umidade inicial

$\mathrm{w}_{\mathrm{f}}$ - teor de umidade final

W - peso da fatia de largura $b$ e altura $h$

x - distância horizontal do ponto de aplicação do peso de cada fatia ao centro de momentos

Z - coordenada de posição 


\section{RESUMO}

CANCINO CALlE, J. A. (2000). Análise de ruptura de talude em solo não saturado. São

Carlos, 2000. 156p Dissertação (Mestrado) - Escola de Engenharia de São Carlos, Universidade de São Paulo.

Apresenta-se neste trabalho uma análise de ruptura de um talude em solo não saturado. O talude, com cerca de $15 \mathrm{~m}$ de altura, é composto de areia fina a média argilosa, com grau de saturação da ordem de 55\% e SPT variando entre 4 golpes no topo a 13 golpes na base. Determinaram-se as seguintes propriedades do solo: Resistência, condutividade hidráulica saturada e não saturada e curva de retenção, além de medir-se a sucção matricial em campo ao longo do ano. Efetuaram-se análises paramétricas para avaliar o efeito da precipitação na mudança do perfil de sucção matricial do terreno e suas implicações na resistência e, por extensão, na estabilidade do talude. Construíram-se, também, ábacos que incluem o efeito da variação da sucção matricial, utilizáveis para taludes com características semelhantes ao talude estudado. Verificou-se que para as condições do talude natural, no auge da estação seca, as sucções matriciais são de tal magnitude que fornecem estabilidade ao talude. À medida que ocorrem precipitações, as sucções matriciais reduzem-se e o fator de segurança do talude diminui, o que justifica a ruptura ocorrida.

Palavras-chave: retro-análise; solo não saturado; estabilidade de taludes; sucção matricial; resistência. 


\begin{abstract}
CANCINO CALLE, J. A. (2000). Slope back analysis in unsatured soils. São Carlos, 2000.

156p Dissertação (Mestrado) - Escola de Engenharia de São Carlos, Universidade de São Paulo.

In this article is showing an slope back analysis in unsaturated soil. The slope, with about $15 \mathrm{~m}$ of height, it is composed of a fine to medium clayey sand, with degree of saturation of the order of 55\% and SPT varying among 4 blows in the top to 13 blows in the base. The following properties of the soil were determined: Resistance, saturated and unsaturated conductivity and it curves of retention, besides measuring the suction along the year. Parametric analyses were made to evaluate the effect of the precipitation in the changes of the ground matricial suction profile and its implications in the resistance and, by extension, in the slope stability. They were also made, some abaci that include the effect of the matricial suction variation, usable for slopes with similar characteristics to the studied slope. It was verified that for the conditions of the natural slope, next to the peak of the dry station, the matricial suction is of such magnitude that it supply stability to the slope. In the successive events of precipitations the matricials suctions is reduced and the slope security factor decreases, that justifies the happened rupture.
\end{abstract}

Keywords: back analysis; unsatured soils; slope stability; suction; shear strength. 


\section{INTRODUÇÃO}

O engenheiro geotécnico se defronta, com frequiência, com diversos problemas associados à estabilidade de taludes. Uma primeira classificação abrangente dos diferentes tipos de taludes, permite enquadrá-los, do ponto de vista genérico, de acordo com o maciço em que se inserem. Tem-se assim os maciços naturais e os artificiais. Os maciços artificiais têm uma composição conhecida, podendo-se mesmo especificar as características de colocação dos diferentes materiais componentes, de sorte a tirar melhor partido das propriedades de cada um deles, como ocorre, por exemplo, num maciço construído para uma barragem de terra.

Em contrapartida, taludes ocorrentes em maciços naturais são o resultado da combinação de diversos fatores de natureza geológica e ambiental. Estes contribuem para conferir ao maciço determinadas características que podem ser alteradas ao longo dos anos pela contínua atuação ou pela alteração dos fatores citados ou pela intervenção humana. Diferentemente, dos maciços artificiais, o nível de detalhe em que se pode conhecer a constituição, as características e as propriedades de engenharia desses maciços depende muito de um minucioso programa de investigação e, mesmo assim, certas particularidades determinantes de seu comportamento podem passar desapercebidas.

Os processos de instabilização de taludes são muitos e variados. Neste particular, pode-se citar a ocorrência de eventos catastróficos, como deslizamentos e corridas de lama, que podem atingir grandes áreas, até pequenas manifestações de erosão superficial, com desprezíveis conseqüências para o entorno ou para vidas humanas. A análise de cada um desses processos demanda a consideração dos diversos condicionantes e de suas importâncias relativas.

Os deslizamentos de terras encontram-se entre os processos de instabilização mais estudados na literatura geotécnica. Na verificação de um talude sujeito à deslizamento empregam-se, com muita frequiência, métodos de análise que se apoiam na teoria do equilíbrio limite. Essa análise passa pela comparação, ao longo de uma superfície de ruptura arbitrada, entre a resistência disponível e a resistência necessária para manter um certo grau de estabilidade, comumente expressos através de um fator de segurança. 
Uma das importantes ferramentas de análise em Geotecnia é o método observacional, através do qual é possível inferir comportamentos e estendê-los à obras semelhantes. Dentro desse espírito é possível definir determinado aspecto de projeto, como, por exemplo, a relação entre inclinação e altura para taludes construídos em uma certa região, com características geológico geotécnicas relativamente homogêneas, a partir da consideração dos taludes estáveis e das rupturas ocorridas em taludes já construídos nessa formação.

Por outro lado, as rupturas em engenharia, à parte seu caráter catastrófico, se constituem em importante fonte de análise de hipóteses de projeto, de modelos de cálculo e dos parâmetros do material em estudo. Pode-se conciliar nessa análise, além do aspecto analítico envolvido no projeto a própria observação de campo e as informações por ela propiciadas.

As rupturas ocorridas podem ser estudadas por retro-análises que, no caso de taludes, envolvem comumente a determinação da superfície de ruptura, dos elementos geométricos do talude, da determinação das características de fluxo subterrâneo e superficial e da observação de particularidades, como trincas de tração, dentre outros fatores. Isto possibilita a determinação de parâmetros de resistência, ou de possíveis relações entre eles, de sorte a terse uma avaliação mais realista dessas propriedades, o que é extremamente útil quando se trabalha com materiais naturais, como é o objeto da Geotecnia.

Em regiões de clima tropical, a atuação intensa dos processos de intemperização dá origem a espessos perfis de solos residuais, muitas vezes recobertos por camadas de materiais transportadas, tais como colúvios. Taludes de corte nessas regiões apresentam feições singulares, com ampla variedade de ocorrência de materiais, com distintas propriedades, que poderão variar tanto em profundidade, quanto lateralmente.

Com muita freqüência, maciços de solos residuais encontram-se não saturados até profundidades consideráveis. Neste caso, um fator complicante da retro-análise é o fato de que a resistência do solo pode variar sazonalmente, em função das flutuações de umidade e, por extensão, da sucção matricial. A Mecânica dos Solos Não Saturados, ainda de aplicação incipiente na prática geotécnica, oferece alternativas de análise para algumas das questões presentes na estabilidade de taludes em solos não saturados, como a infiltração de água da chuva e a influência da sucção matricial na envoltória de resistência, por exemplo.

A proposta deste trabalho é avaliar uma ruptura de talude em solo na Rodovia São Carlos - Ribeirão Preto (São Paulo), empregando conceitos da Mecânica dos Solos Não Saturados. A pesquisa envolveu uma parte de investigação de campo, através de sondagens de simples reconhecimento, com medidas de SPT, de medidas de sucção matricial ao longo de um ano, da medida da condutividade hidráulica e da retirada de amostras deformadas e 
indeformadas, além de determinar-se a geometria do talude e da ruptura e observar-se as particularidades ocorrentes no talude.

Em conjunto com os trabalhos de campo, realizou-se uma investigação laboratorial que consistiu na execução de ensaios de caracterização, de permeabilidade, de resistência ao cisalhamento (solo saturado e não saturado) e da determinação da curva de retenção de água.

De posse esses dados, passou-se à fase de análise que consistiu na avaliação das condições iniciais de sucção matricial e sua variação como resultado de precipitações pluviométricas, procedendo-se, concomitantemente, a análises de estabilidade, de sorte a verificar diferentes aspectos que poderiam condicionar a ruptura de talude em questão. 


\section{REVISÃO BIBLIOGRÁFICA}

\subsection{SOLOS NÃO SATURADOS}

Um solo não saturado caracteriza-se por conter três fases, a fase sólida, a fase gasosa e a fase líquida, comumente água. A presença de sólidos, de ar e de água faz com que ocorram diferentes interfaces e interações entre estes componentes. Por exemplo, a água molha as partículas sólidas, existem interfaces ar-água e o ar pode encontrar-se no interior da água, seja na forma de bolhas ou dissolvido.

Sabe-se da Física que em interfaces ar-água desenvolve-se uma membrana contráctil, decorrente do fato de que as moléculas de água na superfície são atraídas para o interior da massa de água com mais intensidade do que pelo ar. Para que ocorra o equilíbrio entre as solicitações, a superfície do líquido se contrai e fica tracionada. A propriedade que expressa o estado de tensão na interface chama-se tensão superficial.

Uma decorrência da tensão superficial é o fato de que se a superfície se contrai e deixa de ser plana, surge um diferencial de pressão entre as duas faces, produzindo-se o fenômeno de capilaridade. O fenômeno de capilaridade manifesta-se em tubos de pequeno diâmetro postos em água, onde para o equilíbrio de forças na direção vertical se produz uma ascensão capilar (hc). É importante observar que esta ascensão independe da pressão atmosférica, porém a pressão na água $u_{\mathrm{w}}$ depende dela. A capilaridade independe da posição do tubo, podendo este estar até na horizontal, porque a "altura" de ascensão depende da tensão superficial e do raio de curvatura do menisco.

Nota-se que por conta da tensão superficial surge uma reação nas paredes do tubo, da qual uma componente tende a comprimir e a outra a aproximar as paredes.

Os vazios nos solos não saturados têm sido assemelhados a tubos capilares e a manifestação da capilaridade introduz um aumento circunstancial da tensão normal entre as partículas. 
Uma representação mais completa e abrangente da atuação da água presente no solo pode ser conseguida através da descrição do estado de energia dessa água. Eliminam-se, assim, classificações arbitrárias como água capilar a água gravitacional.

\subsubsection{POTENCIAL DA ÁGUA DO SOLO}

O estado de energia da água do solo pode ser expresso como a soma das duas formas clássicas de energia, a Cinética e a Potencial. Sendo a velocidade da água no solo reduzida considera-se a energia cinética nula, portanto a energia potencial pode caracterizar o estado de energia da água do solo (Baver et al. 1972).

Quando um trabalho é realizado sobre a água, sob condições específicas, sua energia potencial é alterada em uma quantidade igual ao trabalho realizado. A variação da energia potencial da água em consideração, com relação a um estado padrão de referência arbitrado, é chamado de Potencial Total da Água do Solo (Marshall \& Holmes, 1981).

A água no estado padrão -Ponto A- encontra-se, livre de sais minerais ou outros solutos, em uma determinada cota, e está sujeita à pressão atmosférica (Figura 2.1).

O Potencial Total da Água do Solo, na Figura 2.1, representa o trabalho útil que deve ser realizado em uma quantidade infinitesimal de água pura, para conduzi-la, reversível e isotérmicamente, desde um reservatório sob condições padronizadas -Ponto A- até a água no solo, na cota de interesse (Ponto B).

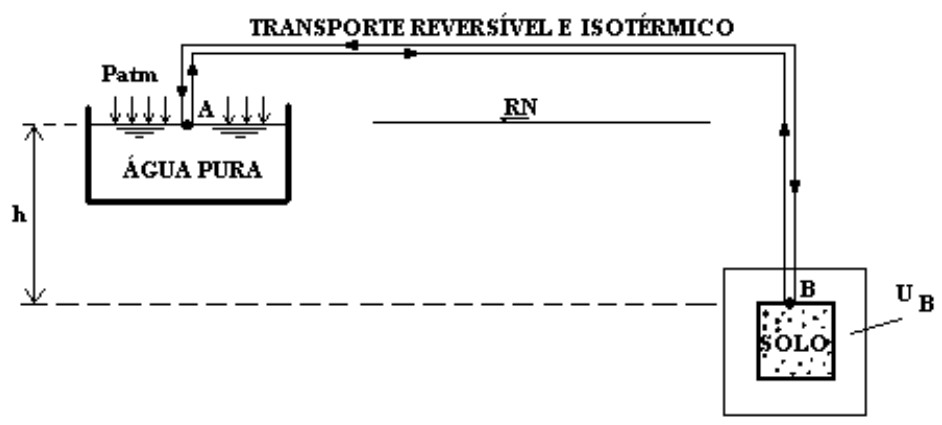

FIGURA 2.1- Esquema ilustrativo da definição de potencial total da água no solo.

Os componentes do potencial total da água do solo são o potencial osmótico, o potencial matricial, o potencial gravitacional, e o potencial pneumático. Outros componentes podem ser incluídos, como, o potencial de consolidação ou o potencial térmico, porém serão descartados por terem importância menor no comportamento geotécnico de solos não saturados. 


\subsubsection{POTENCIAL MATRICIAL $\left(\psi_{\mathrm{M}}\right)$}

O Potencial Matricial é um potencial de pressão e resulta do efeito combinado da ação de forças capilares e de adsorsão, que surgem devido à interação entre a água e as partículas minerais (matriz) que compõem o solo (Figura 2.2). Ele equivale ao potencial total quando a água do solo é idêntica à água do reservatório padrão (água pura ou solução com a mesma composição da água do solo), está à mesma cota $(\mathrm{h}=0)$ e sob a mesma pressão $\left(\mathrm{u}_{\mathrm{A}}=\right.$ Patm) que o reservatório padrão.

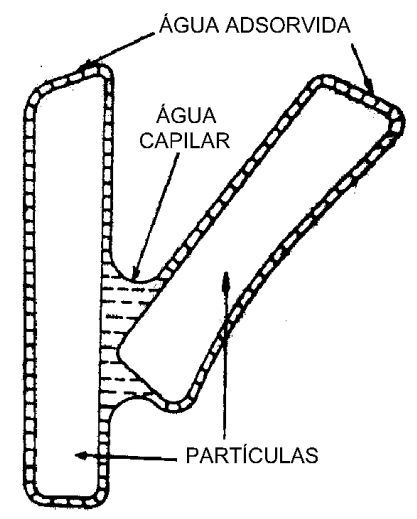

FIGURA 2.2- Água de um solo não saturado sujeita a capilaridade e absorção que combinadas produzem um potencial matricial (Hillel, 1971).

\subsubsection{POTENCIAL OSMÓTICO $\left(\psi_{\mathrm{o}}\right)$}

O Potencial Osmótico ou de soluto, é aquele produzido pela diferença de composição entre a água do solo (presença de sais minerais e substâncias orgânicas) e a água pura. Ele equivale ao potencial total, quando tanto a água pura do reservatório padrão quando a solução de água do solo encontra-se à mesma cota $(\mathrm{h}=0)$, à mesma pressão $\left(\mathrm{u}_{\mathrm{B}}=\mathrm{Patm}\right)$ e não ocorrem efeitos da matriz do solo (solo saturado).

Geralmente com teor de umidade alto esta componente é desprezível. Sua importância cresce quando a concentração salina é significante ou quando o teor de umidade é muito baixo (Reichardt, 1985).

\subsubsection{POTENCIAL GRAVITACIONAL $\left(\psi_{\mathrm{Z}}\right)$}

O Potencial Gravitacional traduz a componente de posição, isto é, o fato de que a água no solo esteja em cota diferente da água do reservatório padrão $(\mathrm{h} \neq 0)$. Ele equivale ao potencial total, quando a água do solo é idêntica à água do reservatório padrão (água pura ou 
solução com a mesma composição da água do solo), está à mesma pressão $\left(\mathrm{u}_{\mathrm{A}}=\mathrm{Patm}\right)$ e o solo se encontra saturado (não existem efeitos decorrentes da matriz do solo)

\subsubsection{POTENCIAL PNEUMÁTICO $\left(\psi_{\mathrm{pn}}\right)$}

Origina-se de pressões externas de gás diferentes da pressão atmosférica e tem especial importância quando se consideram os ensaios de placa de pressão ou a técnica translação de eixos. Ele é equivalente ao potencial total desde que a água do solo seja idêntica à água do reservatório padrão, esteja à mesma cota $(\mathrm{h}=0)$ que o reservatório padrão, porém sujeita à pressão diferente da atmosférica $\left(\mathrm{u}_{\mathrm{B}} \neq \mathrm{Patm}\right)$ e que o solo esteja saturado.

\subsubsection{POTENCIAL TOTAL}

Considerando que o solo esteja saturado e não esteja sujeito a variações de volume e temperatura ou a pressões de gás, diferentes da atmosférica, o potencial total da água do solo pode ser expresso como:

$$
\psi=\psi_{p}+\psi_{O}+\psi_{z}
$$

Onde $\psi_{p}$ é o potencial de pressão, decorrente, por exemplo, da submersão do solo.

No caso de se considerar uma massa de solo não saturado, nas mesmas condições anteriores, a componente de pressão passa a ser representada pelo potencial matricial e neste caso o potencial total da água será:

$$
\psi=\psi_{M}+\psi_{O}+\psi_{z}
$$

A interação solo-água pode também ser quantificada a partir da afinidade que um solo não saturado tem por água. Se colocado em contato com um reservatório de água o solo absorve água, isto é, ele exerce uma sucção sobre a água. Se uma pressão de sucção é aplicada sobre o reservatório de água livre, quando o fluxo cessar tem-se uma pressão na água livre equivalente à pressão na água do solo, o que se constitui numa medida da sucção do solo.

A sucção total do solo é definida como a pressão manométrica negativa, em relação à pressão externa de gás sobre a água do solo, que deve ser aplicada a um reservatório de água pura (à mesma cota e temperatura) de sorte a que se mantenha o equilíbrio, através de uma membrana semi-permeável (permite o fluxo de água porém não o de solutos), entre a água do reservatório e a água do solo. A Figura 2.3 esquematiza essa definição. 


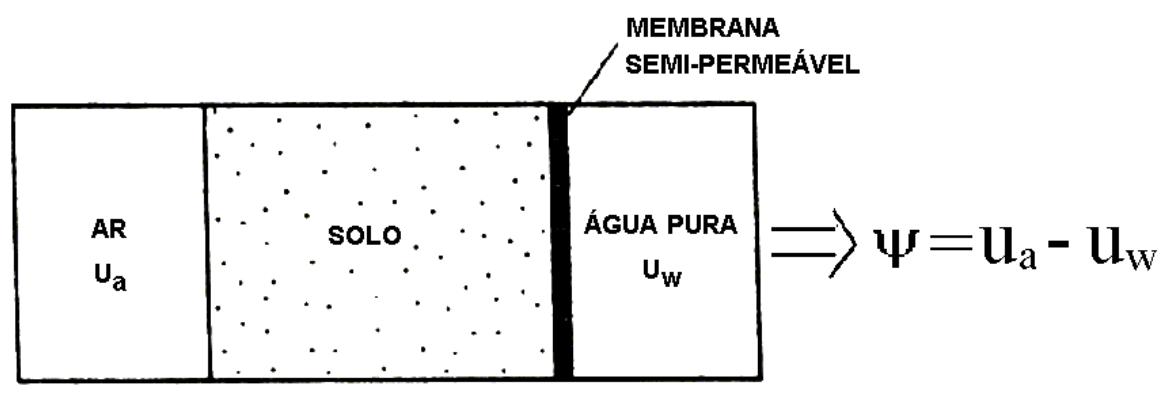

FIGURA 2.3- Esquema ilustrativo da definição de sucção: Corresponde $a u_{a}-u_{w}$ de sorte a não haver fluxo através da membrana semi-permeável. Comumente $\mathrm{u}_{\mathrm{a}}=$ Patm.

Deve-se notar que a sucção total corresponde ao potencial total, quando o potencial gravitacional pode ser desprezado. Dessa forma, a sucção total pode ser separada em suas duas componentes, a sucção osmótica e a sucção matricial, que correspondem, respectivamente, ao potencial osmótico e ao potencial matricial.

A sucção osmótica $\left(\psi_{\mathrm{O}}\right)$ equivale à sucção total quando o solo se encontra saturado, ou seja, quando a componente matricial não ocorre, restando apenas o efeito da concentração de solutos.

Em contrapartida, a sucção matricial $\left(\psi_{\mathrm{M}}\right)$ equivale à sucção total quando a água do solo é idêntica à água padrão (água pura ou solução com a mesma composição da água do solo), restando apenas o efeito da matriz do solo (capilaridade e adsorsão)

A Figura 2.4 ilustra os conceitos de sucção matricial, osmótica e total.

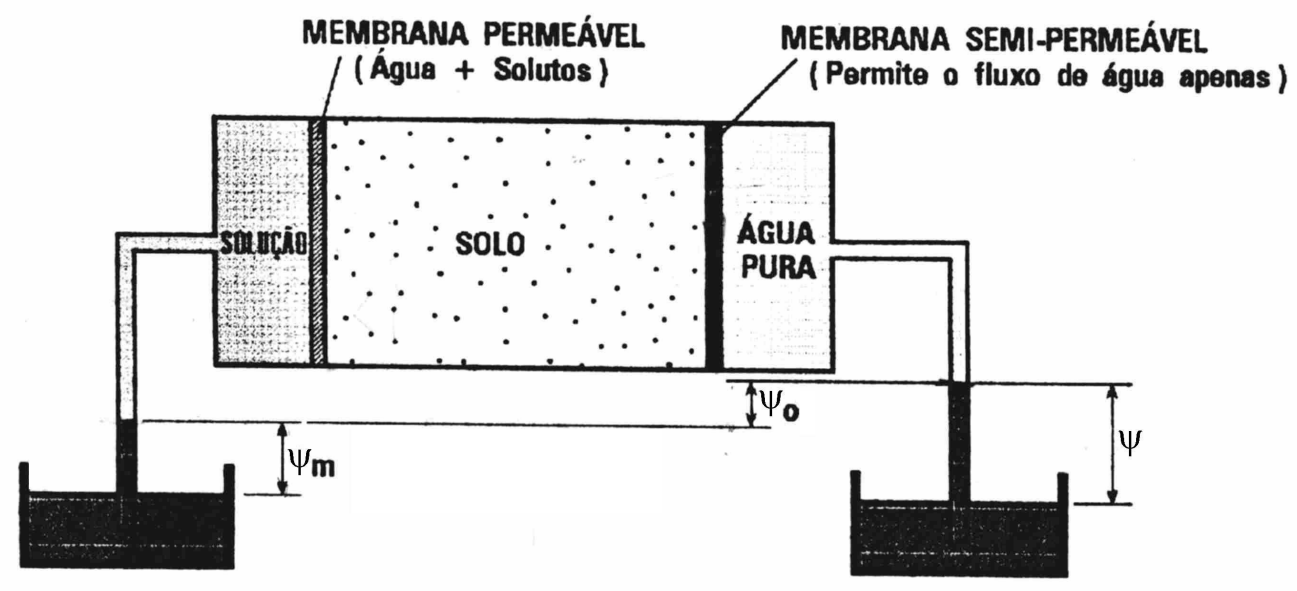

FIGURA 2.4- Representação dos conceitos de sucção matricial, osmótico e total.

Pode-se escrever então,

$\psi=\psi_{\mathrm{M}}+\psi_{\mathrm{O}}=\mathrm{u}_{\mathrm{a}}-\mathrm{u}_{\mathrm{w}}$ 
Em mecânica dos solos, tem-se, rotineiramente, atribuído uma mudança na sucção total à variações na sucção matricial (sucção osmótica desprezível), de sorte que,

$$
\psi=\psi_{\mathrm{M}}=\mathrm{u}_{\mathrm{a}}-\mathrm{u}_{\mathrm{w}}
$$

\subsubsection{CURVA DE RETENÇÃO DA ÁGUA DO SOLO}

A curva de retenção de água do solo representa uma relação entre o potencial matricial e o teor de umidade ou grau de saturação do solo (Figura 2.5). Outras terminologias desta relação são: curva de sucção matricial e curva característica. Esta relação não é unívoca, dependendo da história de variação do teor de umidade.

Segundo Hillel (1971) a sucção total do solo é influenciada pela variação da umidade, produzindo-se uma diminuição da sucção total quando a umidade é incrementada. Portanto a curva de retenção, é uma representação da capacidade do solo de armazenar água (Klute \& Dirksen, 1986).

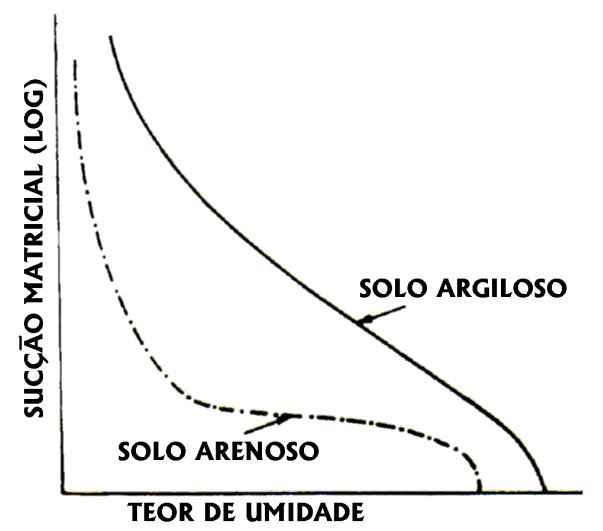

FIGURA 2.5- Curva característica de solos argilosos e arenosos (Hillel, 1971).

A curva de retenção é determinada em laboratório segundo os seguintes procedimentos, (Figura 2.6):

a) por secagem: (ou desidratação), quando a amostra previamente saturada é exposta a potenciais matriciais crescentes, o que implica ir diminuindo a umidade do solo; e

b) por umedecimento: (molhamento ou hidratação), quando uma amostra seca tem o potencial matricial reduzido gradualmente, incrementando-se a umidade. 


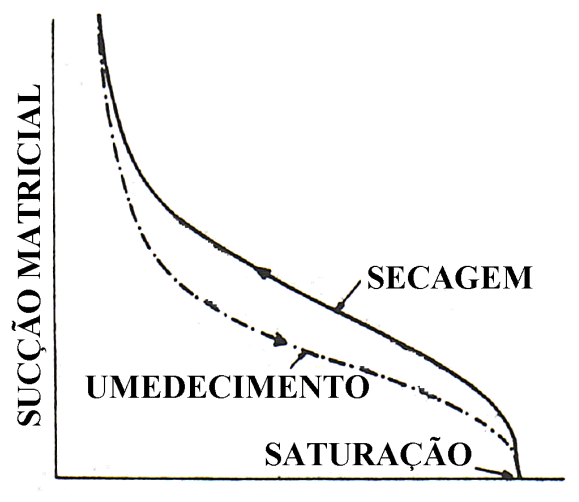

TEOR DE UMIDADE

FIGURA 2.6- Curvas características por umedecimento e secagem (Hillel, 1971).

Pode-se ver na Figura 2.6 que as curvas de secagem e umedecimento não coincidem, denominando-se este fenômeno de histerese.

A forma mais comum de se determinar a curva de retenção do solo é por secagem. Quando uma amostra de solo fica exposta a sucções matriciais crescentes, inicia-se um fluxo de água para fora da amostra a partir de um determinado valor de sucção matricial. Este fato se dá quando o maior poro do solo esvazia-se; o valor da sucção matricial neste momento é denominado de air-entry value (valor de registro de passagem de ar, valor de entrada de ar ou sucção matricial crítica).

Na Figura 2.5 o valor da sucção matricial crítica, de um modo geral, é menor para solos granulares do que para os solos finos. Além disso, como nos solos granulares existem possibilidades maiores de uniformização granulométrica (mal graduado) e porosimétrica, a sucção matricial crítica mostra-se melhor caracterizada nestes do que nos solos finos (Hillel, 1971 e Reichardt, 1985).

Os principais fatores que interferem na forma da curva de retenção dos solos são a distribuição granulométrica, a distribuição dos poros, a estrutura e a mineralogia das partículas.

Nos solos arenosos a maioria dos poros são relativamente grandes e a uma dada sucção matricial muitos poros se esvaziam e poucos ainda podem reter água. Nos solos argilosos a distribuição de poros é melhor, assim a cada sucção matricial apenas uma parcela dos poros drenam, permanecendo ainda uma certa quantidade cheia de água. Portanto nos solos argilosos não se verificam variações bruscas na curva de retenção.

A estrutura do solo também afeta a forma da curva de retenção. Comparando-se a curva de retenção de um mesmo solo agregado em suas condições naturais e compactada, pode-se observar que a compactação conseguiu diminuir as dimensões dos grandes poros 
entre os agregados; contudo, os microporos internos aos agregados permaneceram inalterados. (Figura 2.7).

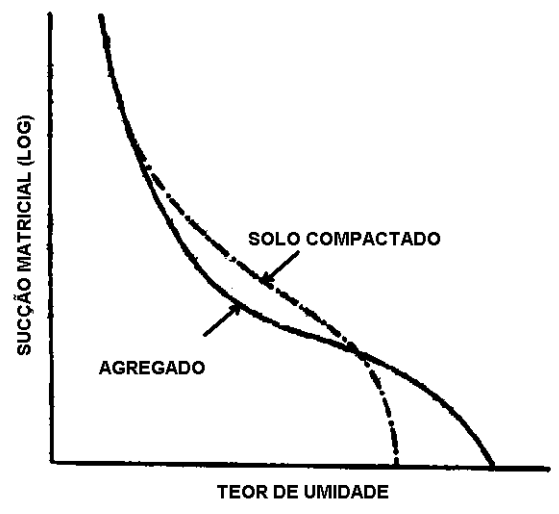

FIGURA 2.7 - Efeito da estrutura do solo na curva de retenção.

A Figura 2.8 mostra curvas de retenção típicas para diferentes tipos de solos, trabalhos realizados por Koorevaar et al. (1983) in Fredlund \& Rahardjo (1993), Croney \& Coleman (1961), in Fredlund \& Rahardjo (1993). Pode-se verificar que as argilas em relação as areias com um mesmo valor de sucção, apresentam um maior conteúdo de água volumétrico, ou seja uma maior capacidade de retenção de água.

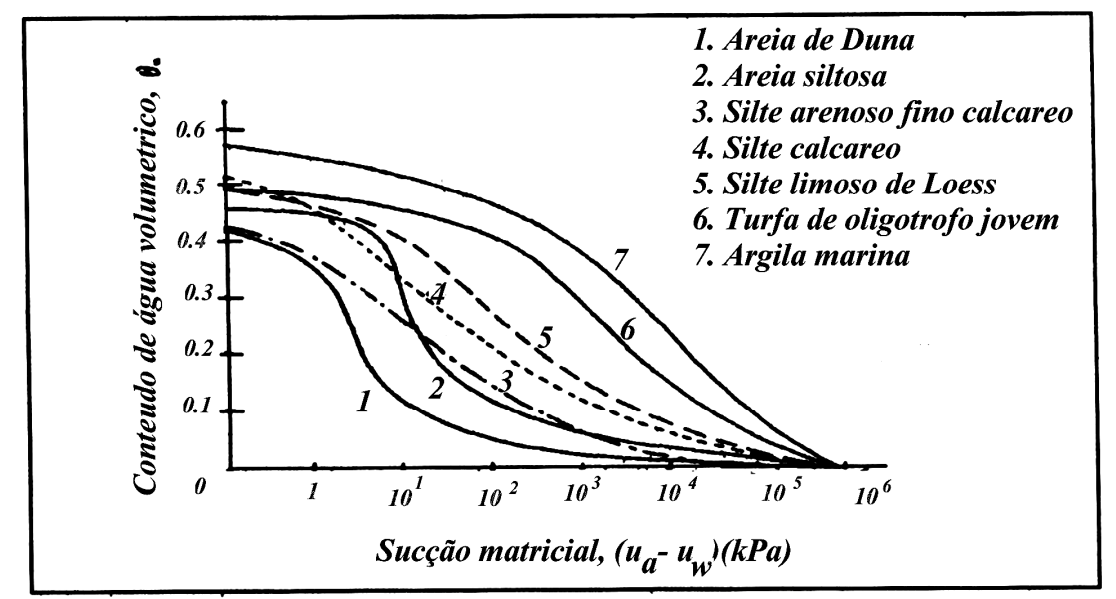

FIGURA 2.8- Curvas características obtidas para diferentes tipos de solos (Koorevar et al., 1983).

A histerese produzida pelos processos de secagem e umedecimento, pode ser atribuída as seguintes razões:

- a não uniformidade de cada poro que gera o efeito "Ink bottle". O esquema simplificado da Figura 2.9 mostra que em ciclos de secagem e embebição podem ocorrer equilíbrios em posições diferentes para um menisco com mesmo raio $\mathrm{R}$, envolvendo quantidades diferentes de água para um mesmo sistema; 
(०)

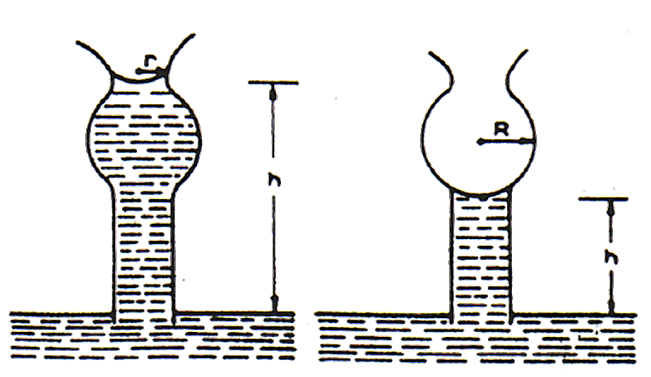

FIGURA 2.9- Efeito "Ink Bottle".

- o efeito do ângulo de contato, que é maior em umedecimento, gerando raios de curvatura diferentes numa e noutra situação;

- bolhas de ar capturadas nos vazios do solo durante o umedecimento; e

- alteração na estrutura do solo decorrentes da expansão ou contração.

Fredlund, Xing \& Huang (1994) mostram a caracterização da curva de retenção, feita a partir das trajetórias típicas obtidas através de procedimentos de secagem e umedecimento, com a finalidade de equacioná-las. (Figura 2.10)

Podem ser identificados os seguintes parâmetros:

$\theta_{\mathrm{s}}$ - umidade volumétrica, correspondente a saturação, para a curva obtida pelo processo de umedecimento;

$\theta^{\prime}{ }_{s}-\quad$ umidade volumétrica, correspondente a saturação, para a curva obtida pelo processo de secagem;

$\theta_{\mathrm{s}}-\theta_{\mathrm{s}}^{\prime}$ conteúdo de ar residual;

$\theta_{\mathrm{s}}=\frac{\mathrm{V}_{\mathrm{w}}}{\mathrm{V}}$

$\mathrm{V}_{\mathrm{w}}-\quad$ Volume de água contido no solo; $\mathrm{e}$

Valor de entrada de ar - valor de registro de passagem de ar ou sucção matricial crítica. 


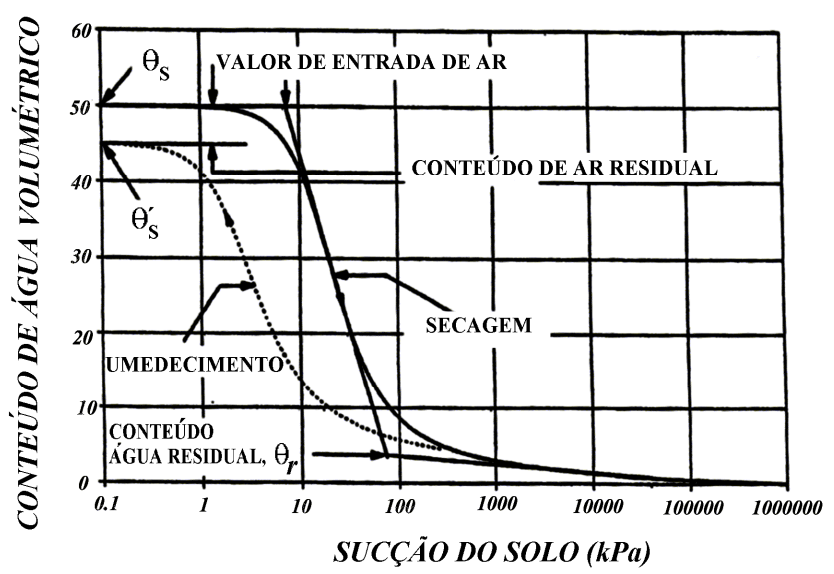

FIGURA 2.10- Caracterização da curva de retenção segundo Fredlund \& Xing (1994).

\subsubsection{RELAÇÕES EMPÍRICAS PARA DEFINIR A CURVA DE RETENÇÃO DE ÁGUA NO SOLO}

A curva de retenção pode ser definida mediante relações empíricas, a partir dos dados de sucção matricial e umidade volumétrica, fornecidos pelos ensaios respectivos, como os mostrados no ítem 2.1.4.

Diversas relações empíricas são comumente usadas para estimar a curva de retenção de água. Algumas delas são apresentadas a seguir:

- BROOKS e COREY (1966) in FREDLUND \& RAHARDJO (1993)

$$
\theta=\left(\theta_{\mathrm{s}}-\theta_{\mathrm{r}}\right)\left(\frac{\psi_{\mathrm{a}}}{\psi}\right)^{\lambda}+\theta_{\mathrm{r}}
$$

- VAN GENUTCHEN (1980)

$$
\mathrm{w}=\mathrm{w}_{\mathrm{r}}+\frac{\left(\mathrm{w}_{\mathrm{s}}-\mathrm{w}_{\mathrm{r}}\right)}{\left(1+|\alpha \psi|^{\mathrm{n}}\right)^{\mathrm{m}}}
$$

$m=1-1 / n$

- FREDLUND, XING e HUANG (1994)

$$
\theta=\theta_{\mathrm{s}}\left[1-\frac{\operatorname{In}\left(1+\frac{\psi}{\psi_{\mathrm{r}}}\right)}{\operatorname{In}\left(1+\frac{10^{6}}{\psi_{\mathrm{r}}}\right)}\left[\frac{1}{\operatorname{In}\left(\mathrm{e}+\left(\frac{\psi}{\mathrm{a}_{\mathrm{r}}}\right)^{\mathrm{n}}\right)}\right]^{\mathrm{m}}\right.
$$


Onde:

$\psi$ - sucção matricial (cm);

$\psi_{\mathrm{a}}$ - sucção matricial que corresponde à entrada de ar (air entry) $(\mathrm{cm})$;

$\psi_{\mathrm{r}}$ - sucção matricial que corresponde à umidade volumétrica residual $(\mathrm{cm})$;

$\theta$ - umidade volumétrica $\left(\mathrm{cm}^{3} / \mathrm{cm}^{3}\right)$;

$\theta_{\mathrm{s}}$ - umidade volumétrica de saturação $\left(\mathrm{cm}^{3} / \mathrm{cm}^{3}\right)$;

$\theta_{\mathrm{r}}$ - umidade volumétrica residual $\left(\mathrm{cm}^{3} / \mathrm{cm}^{3}\right)$;

$\alpha$ - parâmetro de ajuste da curva $(1 / \mathrm{cm})$;

$\lambda$ - parâmetro de ajuste, depende do tipo de solo;

e - 2,71828;

$\mathrm{a}_{\mathrm{r}}$ - valor aproximado da sucção matricial de entrada de $\operatorname{ar}(\mathrm{cm})$;

n,m - parâmetros de ajuste; e

$10^{6}$ - valor limite de sucção matricial para qualquer tipo de solo $(\mathrm{kPa})$.

\subsubsection{MEDIÇÃO DA SUCÇÃO DO SOLO}

A variação do clima e as variações das cargas aplicadas, produzem uma alteração do conteúdo da água do solo. O conteúdo inicial da água do solo parece ter uma relação direta com a componente da sucção matricial. Por outro lado, a sucção osmótica parece não ser sensitiva as variações do conteúdo da água no solo. Como resultado, uma variação na sucção total é mais influenciada pela variação da sucção matricial (Fredlund \& Rahardjo, 1993).

\subsubsection{MEDIDA DA SUCÇÃO TOTAL}

Pode ser feita direta ou indiretamente, com o psicrômetro e o papel filtro, respectivamente.

\section{a) Psicrômetro}

São aparelhos que servem para medir a sucção total do solo através da medição da umidade relativa do ar nele, em equilíbrio com a interface solo-água. Trata-se de um bulbo poroso fino que entra em contato com o solo que permite estabelecer um equilíbrio entre o teor de umidade relativo do ar dos vazios do solo e do ar do seu interior. Imerso no interior do bulbo poroso encontra-se um termopar ligado a um microvoltímetro, uma fonte de alimentação elétrica, e um sensor de temperatura como o mostrado na Figura 2.11. 


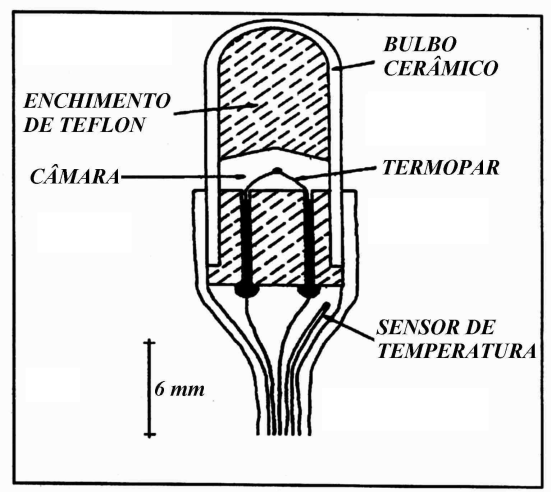

FIGURA 2.11- Esquema de um Psicrômetro.

Quando circula a corrente na direção adequada para o abaixamento da sua temperatura, fica coberto por uma certa quantidade da água que se condensou, transformandose em um bulbo úmido. Quando a água condensada começa a se evaporar, é criada uma diferença de potencial entre esta junta e outra de referência, que resulta numa corrente elétrica. A magnitude da corrente elétrica depende, dentre outros fatores, da taxa de evaporação da água condensada sobre a junta, que é função da umidade relativa do ar no interior do bulbo poroso. Assim, admitido o equilíbrio do ar no interior do bulbo com o ar do solo, a sucção total pode ser obtida através da seguinte relação (Campos, 1994):

$$
\psi=\frac{\mathrm{RT}}{\mathrm{w}_{\mathrm{v}}} \rho_{\mathrm{w}} \operatorname{In}\left(\frac{\mathrm{u}_{\mathrm{v}}}{\mathrm{u}_{\mathrm{vo}}}\right)
$$

onde:

$\psi$ - $\quad$ sucção matricial $(\mathrm{kPa})$;

$\rho_{\mathrm{w}}-\quad$ massa específica da água $\left(998 \mathrm{~kg} / \mathrm{m}^{3}\right.$ a $\left.20^{\circ} \mathrm{C}\right)$;

$\mathrm{R}$ - $\quad$ constante universal dos gases $(8,31432 \mathrm{~J} / \mathrm{molK})$;

$\mathrm{T}$ - $\quad$ temperatura $\left({ }^{\circ} \mathrm{K}\right)$;

$\mathrm{W}_{\mathrm{v}}$ - $\quad$ massa molecular do vapor de água $(18,016 \mathrm{~kg} / \mathrm{molK})$;

$\mathrm{u}_{\mathrm{v}}$ - pressão parcial do vapor de água dos poros $(\mathrm{kPa})$; e

$\mathrm{u}_{\mathrm{vo}}$ - $\quad$ pressão de saturação do vapor de água a mesma temperatura de $\mathrm{u}_{\mathrm{v}}(\mathrm{kPa})$.

\section{b) Papel filtro}

Segundo Chandler \& Gutierrez (1986), este método é utilizado para medida indireta da sucção matricial e consiste em colocar o papel filtro diretamente sobre o solo.

Neste processo a sucção do papel equilibra-se com a sucção matricial do solo. Uma vez atingido o equilíbrio mede-se a umidade do papel filtro e infere-se a sucção matricial do solo segundo uma curva de calibração do papel filtro. 
Se o papel filtro estiver colocado diretamente sobre o solo a sucção medida será a matricial, e se o papel filtro não estiver em contato íntimo com o solo, será medida a sucção total (Campbell \& Gee, 1986).

Segundo Chandler \& Gutierrez (1986) o papel filtro deve ser usado diretamente da caixa no estado seco ao ar. A Norma ASTM-DS298-92 sugere que o papel filtro seja seco em estufa no mínimo $16 \mathrm{~h}$ antes do seu uso. No entanto, este procedimento pode afetar as características de adsorsão do papel resultando na alteração da curva de calibração, (Marinho, 1995)

Segundo Marinho (1995), para o papel filtro Whatman No 42 a umidade inicial no estado seco ao ar é aproximadamente $6 \%$, isto permite medições de sucção matricial de 0 a $29 \mathrm{MPa}$, sendo esta a máxima sucção matricial que o solo pode ter para que o papel filtro absorva água do mesmo. Por outro lado, o papel filtro pode ser utilizado inicialmente saturado, porem é necessária uma calibração especifica.

Na Tabela 2.1, são mostradas algumas correlações usadas para a determinação da pressão de sucção matricial (expressos em cm de água) em função da umidade de equilíbrio do papel.

Segundo Fredlund e Rahardjo (1993), o tempo de resposta do papel é da ordem de no mínimo uma semana. A técnica requer manuseio do papel e precisão da pesagem (da ordem de $0.001 \mathrm{~g})$.

TABELA 2.1- Correlações para determinação da sucção matricial com o método do papel filtro.

\begin{tabular}{|c|c|c|c|}
\hline Autor & Tipo de papel & Correlação & Observação \\
\hline $\begin{array}{l}\text { Fawcett \& Collis-George, } \\
(1967)\end{array}$ & Whatman Nro 42 & $\mathrm{pF}=5,777-0,060 \mathrm{w}_{\mathrm{p}}$ & pF entre 2,6 e 4,5 \\
\hline McQueen Miller, (1968) & Schleider \& Schull Nro. 589 & $\mathrm{pF}=6,246-0,0723 \mathrm{w}_{\mathrm{p}}$ & $\mathrm{pF}$ entre 2,3 e 5,9 \\
\hline Hamblin, (1981) & Whatman Nro 42 & $\mathrm{pF}=6,281-0,0822 \mathrm{w}_{\mathrm{p}}$ & \\
\hline $\begin{array}{l}\text { Chandler \& Gutierrez, } \\
(1986)\end{array}$ & Whatman Nro 42 & $\mathrm{pF}=5,85-0,062 \mathrm{w}_{\mathrm{p}}$ & $\begin{array}{l}\mathrm{pF} \text { entre } 2,9 \text { e } 4,8 \\
\mathrm{w}_{\mathrm{p}} \text { entre } 17 \% \text { e } 47 \% \\
\text { sucção matricial entre } 80 \\
\text { e } 600 \mathrm{kPa}\end{array}$ \\
\hline Chandler et al., (1992) & Whatman Nro 42 & $\begin{array}{l}\psi=10^{6,05-2,48 \operatorname{logwp}} \\
\psi=10^{4,84-0,0622 \mathrm{wp}}\end{array}$ & $\begin{array}{l}\mathrm{w}_{\mathrm{p}} \geq 47 \% \\
\mathrm{w}_{\mathrm{p}}<47 \% \\
\mathrm{~S} \text { em kPa }\end{array}$ \\
\hline ASTM D5298 & Whatman Nro 42 & $\begin{array}{l}\mathrm{pF}=6,327-0,0779 \mathrm{w}_{\mathrm{p}} \\
\mathrm{pF}=3,412-0,0135 \mathrm{w}_{\mathrm{p}}\end{array}$ & $\begin{array}{l}\mathrm{w}_{\mathrm{p}}<54 \% \\
\mathrm{w}_{\mathrm{p}}>54 \% \\
\mathrm{pF}>2,1 \\
\text { Sucção matricial }>50 \mathrm{Kpa}\end{array}$ \\
\hline
\end{tabular}


Onde:

pF: logaritmo de pressão expresso em centímetros de água;

$\psi: \quad$ sucção matricial; e

$\mathrm{w}_{\mathrm{p}}$ : umidade do papel.

\subsubsection{MEDIDA DA SUCÇÃO MATRICIAL}

Pode-se medir direta ou indiretamente. A câmara de pressão de alta entrada de ar, o funil de placa porosa e o tensiômetro são utilizados para a medição direta da sucção matricial no solo, e vários tipos de sensores são usados para a medição indireta da mesma.

\section{a) Funil de placa porosa}

É o equipamento utilizado para sucções matriciais com limitação de medição de $70 \mathrm{kPa}$ devido ao problema de cavitação ou pressão de borbulhamento da pedra porosa. No entanto, na prática não resulta possível utilizar um funil de $7 \mathrm{~m}$ de altura de água, sendo estes geralmente pequenos. Na Figura 2.12 pode-se ver um esquema que aplica a sucção matricial através da placa porosa.

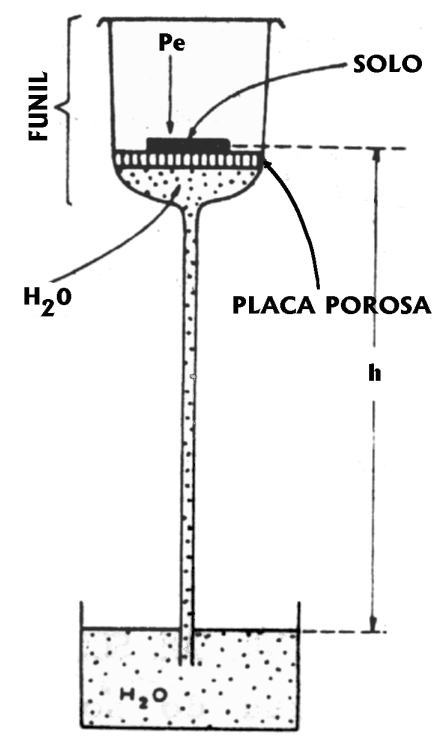

FIGURA 2.12- Funil de placa porosa (Reichardt, 1985).

A sucção matricial estará dada pela altura de água (h), visto que a pressão no ar é a atmosférica.

\section{b) Placas ou membranas de pressão}

Usadas para sucções matriciais superiores a 70kPa. 
Pelo fato da água cavitar a 1 atm., é aplicada uma pressão de ar sobre uma placa porosa de alta pressão de entrada de ar, que tem a face inferior ligada à pressão atmosférica. $\mathrm{O}$ aparelho é constituído de uma câmara e do elemento de alta entrada de pressão de ar, e podese atingir sucções matriciais até cerca de 15000kPa. Figura 2.13.

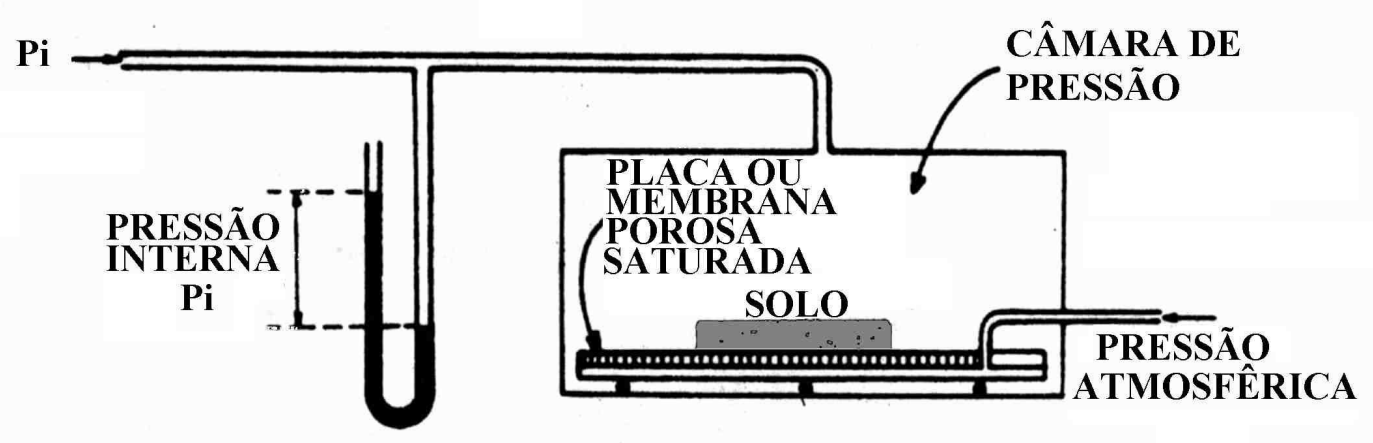

FIGURA 2.13- Câmara de pressão (Reichardt, 1985).

O ensaio é realizado da seguinte maneira: coloca-se um corpo de prova sobre a pedra porosa saturada, em seguida, aplica-se uma pressão de ar, fazendo com que a sucção matricial induzida seja transmitida ao solo, até que ocorra a eliminação parcial da água para este estagio. Após disto, o corpo de prova é pesado para determinação de sua umidade. Repete-se este procedimento sucessivas vezes, até não ocorrer mais variações de umidade no corpo de prova; nesta condição, a pressão de ar aplicada será igual a sucção matricial do solo.

Com os dados de sucção matricial e de umidade respectivamente para cada estagio pode-se obter a curva de retenção do solo.

\section{c) Tensiômetro}

Permite medir diretamente a sucção matricial do solo. Consiste de um tubo de plástico que num extremo tem uma placa porosa de alta entrada de ar que fica em contato direto com o solo, e no outro extremo, tem-se instalado um manômetro. O tubo é enchido de água e introduzido a qualquer profundidade no solo até atingir um bom contato com ele, ou seja, um contato direto solo e pedra porosa.

Uma vez atingido o equilíbrio entre o solo e o sistema de medição, a água no tensiômetro terá a mesma sucção matricial do solo.

A pressão máxima que se pode medir com o tensiômetro é da ordem de $70 \mathrm{kPa}$, devido à possível cavitação da água.

A Tabela 2.2 apresenta uma síntese de métodos para a determinação da sucção do solo. 
TABELA 2.2- Métodos para a medida de sucção (Vilar, 1997).

\begin{tabular}{|c|c|c|c|c|}
\hline Método & Realizado em: & $\begin{array}{c}\text { Tipo de sucção } \\
\text { matricial }\end{array}$ & $\begin{array}{c}\text { Faixa de medida } \\
(\mathrm{kPa})\end{array}$ & Observação \\
\hline $\begin{array}{l}\text { Funil de pedra } \\
\text { porosa }\end{array}$ & Laboratório & Matricial & $0-70$ & $\begin{array}{l}\text { Para baixas sucções. } \\
\text { Sucção aplicada diretamente à amostra }\end{array}$ \\
\hline Tensiômetros & $\begin{array}{l}\text { Laboratório e } \\
\text { campo }\end{array}$ & Matricial & $0-70$ & $\begin{array}{l}\text { Tempo de resposta em função da } \\
\text { condutividade da pedra porosa. }\end{array}$ \\
\hline $\begin{array}{l}\text { Blocos } \\
\text { porosos }\end{array}$ & $\begin{array}{l}\text { Laboratório e } \\
\text { campo }\end{array}$ & Matricial & $10-1000$ & $\begin{array}{l}\text { Histerese pronunciada; mais sensível às } \\
\text { altas sucções. } \\
\text { Longo tempo de resposta. } \\
\text { Fácil deterioração do material. } \\
\text { Blocos compostos de gesso, fibra de } \\
\text { vidro, etc. }\end{array}$ \\
\hline $\begin{array}{ll}\text { Placa } & \text { de } \\
\text { pressão } & \end{array}$ & Laboratório & Matricial & $20-1500$ & $\begin{array}{l}\text { A capacidade depende da pedra porosa } \\
\text { (pressão de entrada de ar), } \\
\text { Utiliza a técnica de translação de eixos. }\end{array}$ \\
\hline Psicrômetro & $\begin{array}{l}\text { Laboratório } \\
\text { campo }\end{array}$ & Total e osmótica & $100-8000$ & $\begin{array}{l}\text { Mais recomendado para laboratório } \\
\text { Depende de rigoroso controle da } \\
\text { temperatura }\end{array}$ \\
\hline $\begin{array}{l}\text { Membrana de } \\
\text { pressão }\end{array}$ & Laboratório & Matricial & Até 10000 & $\begin{array}{l}\text { Emprega a técnica de translação de eixos } \\
\text { Emprega membrana de celulose }\end{array}$ \\
\hline Papel filtro & Laboratório & Matricial e total & Todos os valores & Precisa máxima precisão na pesagem \\
\hline $\begin{array}{ll}\text { Extrato } & \text { da } \\
\text { solução } & \text { do } \\
\text { solo } & \end{array}$ & & Osmótica & Todos os valores & $\begin{array}{l}\text { Condutividade do estrato } \\
\text { Concentração de solutos } \\
\text { Estrato e psicrômetro (resolução não } \\
\text { satisfatória) }\end{array}$ \\
\hline
\end{tabular}

\subsubsection{CONDUTIVIDADE HIDRÁULICA}

As propriedades hidráulicas do solo que determinam o comportamento do fluxo da água em seus vazios são a condutividade hidráulica e a curva de retenção do solo. A condutividade hidráulica do solo é uma medida da sua capacidade de transportar água, e a curva de retenção, como se viu, é uma representação da capacidade do solo armazenar água.

A condutividade hidráulica dos solos não saturados depende dos mesmos fatores que influenciam a permeabilidade dos solos saturados. Entretanto, autores como Tavenas et al (1983) e Smiles et al (1985) admitem que a salinidade e a temperatura também interferem de forma significativa no processo.

Segundo Richards (1974) em um solo saturado que perde água até transformar-se em um solo não saturado, e que continua a diminuir seu grau de saturação, o ar vai 
progressivamente substituindo a água dos poros. Durante este processo de perda de umidade, pode ocorrer, também, uma retração dos poros, diminuindo a condutividade hidráulica. Os fatores que geram esta perda de capacidade de transmitir a água são:

a) a área total disponível para o fluxo da água decresce com a diminuição da quantidade de poros saturados por água, porque o ar passa a ocupar o lugar da água e obstrui sua trajetória original;

b) o esvaziamento dos poros avança dos maiores para os menores, acarretando uma diminuição da condutividade hidráulica porque o fluxo da água, segundo a equação de Poiseuille para fluxos laminares em tubos capilares, é diretamente proporcional ao quadrado do raio do tubo; e,

c) com o enchimento dos poros de ar, aumenta a quantidade de água que fica isolada e descontínua em diversos poros do solo, o que dificulta o fluxo da água como líquido.

Complementando, Miller \& Low (1963) referem que para sucções matriciais muito altas, além do aumento da tortuosidade e das diminuições da quantidade e das dimensões dos poros que conduzem a água do solo, também ocorre uma alteração na viscosidade da água, que começa a se aproximar, cada vez mais, da camada adsorvida pelas partículas sólidas.

Topp \& Miller (1966) apresentaram resultados (provenientes de amostras constituídas de esferas de vidro) que mostram a influência do grau de saturação do meio poroso na condutividade hidráulica.

\subsubsection{CONDUTIVIDADE HIDRÁULICA SATURADA}

Nos solos, o fluxo de água em geral é laminar. O movimento de água do solo, em fluxo laminar, é quantificado através da Lei de Darcy, que pode ser expressa como:

$\mathrm{v}=\mathrm{K} \Delta \mathrm{h} / \mathrm{L}$

Onde "v" é a velocidade de descarga, "K" o coeficiente de condutividade hidráulica, " $\Delta \mathrm{h}$ " a perda de carga e "L" o comprimento do solo.

Dentro das técnicas de ensaios de laboratório para solos saturados, os aparelhos para determinar a condutividade hidráulica são os permeâmetros que por sua variedade podem ser classificados conforme mostrado na Tabela 2.3 (Daniel e Stephen, 1994): 
TABELA 2.3- tipos de Permeâmetros (Daniel \& Stephen, 1994).

\begin{tabular}{|l|l|}
\hline \multicolumn{1}{|c|}{ Tipo } & \multicolumn{1}{c|}{ Sub-tipo } \\
\hline Parede rígida & Com molde para compactar amostras \\
& Com molde amostrador \\
& Para amostras envolvidas com selo anular impermeabilizador \\
& A partir de consolidômetros. \\
\hline Parede flexível & \\
\hline
\end{tabular}

Os ensaios utilizando os permeâmetros são calculados considerando a lei de Darcy e, basicamente, existem duas formas de conduzi-los:

- Ensaios a carga constante: onde a carga hidráulica é mantida constante e a vazão correspondente é medida. Este ensaio é o mais indicado para materiais arenosos que possuem condutividades hidráulicas elevadas; e

- Ensaios a carga variável: Onde a carga hidráulica varia com o tempo, a medição da vazão é feita a partir das medidas da variação do nível de água. Usado principalmente para determinação da condutividade hidráulica de solos argilosos, os quais, sendo praticamente impermeáveis, são atravessados por uma quantidade de água muito pequena durante o ensaio.

\subsubsection{CONDUTIVIDADE HIDRÁULICA NÃO SATURADA}

É chamado fluxo de água não saturado aquele que ocorre no solo em qualquer condição de umidade menor que a de saturação. Experiências de Richards (1931), Childs e Collis-George (1950), mostram que a lei de Darcy pode-se aplicar a solos não saturados com a expressão:

$$
v=-K(\theta) \frac{\partial \psi}{\partial z}
$$

Onde:

$\mathrm{K}(\theta)$ : condutividade hidráulica não saturada $(\mathrm{m} / \mathrm{s})$;

$\mathrm{v}$ : $\quad$ velocidade (ou densidade) de descarga $(\mathrm{m} / \mathrm{s})$;

$\theta$ : $\quad$ umidade volumétrica $\left(\mathrm{m}^{3} / \mathrm{m}^{3}\right)$;

z: $\quad$ coordenada de posição $(\mathrm{m})$; e

$\psi$ : $\quad$ potencial total do solo não saturado.

Uma das primeiras relações para a determinação do coeficiente de condutividade hidráulica para solos não saturados foi apresentada por Childs \& Collis George (1950). O método baseia-se na variação dos tamanhos dos poros do solo, partindo do princípio de que a 
porosidade é um fator muito importante nos solos não saturados, e a distribuição dos poros influencia nos potenciais capilares (sucção matricial). O método foi modificado por Kunze et al., (1968) (in Fredlund, Xing e Huang, 1994).

Diversos autores têm proposto formulações alternativas para a função condutividade hidráulica. Muitas delas apoiam-se na curva de retenção de água no solo, como a de Van Genuchten (1980)

Na Tabela 2.4, são mostradas algumas relações empíricas, classificadas em função da umidade volumétrica, do grau de saturação ou da sucção matricial, coletadas de Alonso, Gens e Hight (1987) e Fredlund, Xing e Huang (1994).

TABELA 2.4 - Relações empíricas para determinação da condutividade hidráulica não saturada.

\begin{tabular}{|c|c|}
\hline Autor & Expressão \\
\hline Gargdner (1958) & $\mathrm{K}(\psi)=\mathrm{K}_{\mathrm{s}} /\left(1+\mathrm{a} \psi^{\mathrm{n}}\right)$ \\
\hline & $\mathrm{K}_{\mathrm{r}}=\exp (-\alpha \psi)$ \\
\hline Brooks \& Corey (1966) & $\mathrm{K}(\psi)=\mathrm{K}_{\mathrm{s}} \quad$ para $\quad \psi<=\psi_{\mathrm{aev}}$ \\
\hline & $\mathrm{K}_{\mathrm{r}}=\left(\psi / \psi_{\mathrm{aev}}\right)^{-\mathrm{n}}$ para $\quad \psi>=\psi_{\text {aev }}$ \\
\hline Richard (1931) & $\mathrm{K}(\psi)=\mathrm{a} \psi+\mathrm{b}$ \\
\hline Irmay (1954) & $\mathrm{K}(\psi)=\mathrm{K}_{\mathrm{s}} *\left(\left(\mathrm{~S}_{\mathrm{r}}-\mathrm{S}_{\mathrm{ru}}\right) /\left(1-\mathrm{S}_{\mathrm{ru}}\right)\right)^{3}$ \\
\hline Corey (1957) & $\mathrm{K}(\psi)=\mathrm{K}_{\mathrm{s}} *\left(\left(\mathrm{~S}_{\mathrm{r}}-\mathrm{S}_{\mathrm{ru}}\right) /\left(1-\mathrm{S}_{\mathrm{ru}}\right)\right)^{4}$ \\
\hline Scott (1963) & $\mathrm{K}(\psi)=\mathrm{K}_{\mathrm{s}} *\left(1-\mathrm{n} *\left(1-\mathrm{S}_{\mathrm{r}}\right)\right)$ \\
\hline Brutsaert (1968) & $\mathrm{K}(\psi)=\mathrm{K}_{\mathrm{s}} * \mathrm{~S}_{\mathrm{r}}{ }^{\mathrm{n}}$ \\
\hline Kovacs (1981) & $\mathrm{K}(\psi)=\mathrm{K}_{\mathrm{s}} *\left(\left(\mathrm{~S}_{\mathrm{r}}-\mathrm{S}_{\mathrm{ru}}\right) /\left(1-\mathrm{S}_{\mathrm{ru}}\right)\right)^{3,5}$ \\
\hline Nielsen et al (1976) & $\mathrm{K}(\psi)=\mathrm{K}_{\mathrm{s}} * \mathrm{~S}_{\mathrm{e}}{ }^{\mathrm{n}}\left(1-\left(1-\mathrm{S}_{\mathrm{e}}{ }^{1 / \mathrm{m}}\right)^{\mathrm{m}}\right)^{2}$ \\
\hline Wind (1955) & $\mathrm{K}(\psi)=\alpha \psi^{-\mathrm{n}}$ \\
\hline Ritjema (1965) & $\begin{array}{lr}\mathrm{K}(\psi)=\mathrm{K}_{\mathrm{s}} & \text { para } \psi<=\psi_{\text {aev }} \\
\mathrm{K}_{\mathrm{r}}=\exp \left(-\alpha\left(\psi-\psi_{\text {aev }}\right)\right) & \text { para } \psi_{\text {aev }}<\psi<\psi_{1} \\
\mathrm{~K}(\psi)=\mathrm{K}_{1}\left(\psi / \psi_{1}\right)^{-\mathrm{n}} \text { para } \psi>\psi_{1}\end{array}$ \\
\hline Davidson et al, (1969) & $\mathrm{K}(\psi)=\mathrm{K}_{\mathrm{s}} * \exp \left(\alpha\left(\theta-\theta_{\mathrm{s}}\right)\right)$ \\
\hline Campbell (1973) & $\mathrm{K}(\psi)=\mathrm{K}_{\mathrm{s}}\left(\theta / \theta_{\mathrm{s}}\right)^{\mathrm{n}}$ \\
\hline Van Genuchten, (1980) & $\left.\mathrm{K}(\psi)=\mathrm{K}_{\mathrm{s}}\left(\left(\theta-\theta_{\mathrm{r}}\right) / \theta_{\mathrm{s}}-\theta_{\mathrm{r}}\right)\right)^{0.5} *\left(1-\left\{1-\left[\frac{\theta-\theta_{\mathrm{r}}}{\theta_{\mathrm{s}}-\theta_{\mathrm{r}}}\right]^{1 / \mathrm{m}}\right\}^{\mathrm{m}}\right)^{2}$ \\
\hline
\end{tabular}

Onde:

$\mathrm{K}(\psi)$ : coeficiente de condutividade hidráulica não saturada; 
$\mathrm{K}_{\mathrm{s}}$ : $\quad$ coeficiente de condutividade hidráulica saturada;

$\mathrm{K}_{\mathrm{r}}=\mathrm{K} / \mathrm{K}_{\mathrm{s}}$ : coeficiente de condutividade hidráulica relativa;

$\theta_{\mathrm{s}}: \quad$ umidade volumétrica saturada;

$\theta_{\mathrm{r}}: \quad$ umidade volumétrica residual;

$\psi_{\text {aev }}:$ sucção matricial no "air entry";

$\psi_{1}$ : $\quad$ sucção matricial residual;

$\mathrm{K}_{1}$ : coeficiente de condutividade hidráulica para $\psi=\psi_{1}$;

$\mathrm{a}, \mathrm{b}, \mathrm{n}, \mathrm{m}, \alpha$ : constantes;

$\mathrm{S}_{\mathrm{r}}: \quad$ grau de saturação;

$\mathrm{S}_{\mathrm{ru}}$ : grau de saturação residual;

$\mathrm{S}_{\mathrm{e}}$ : $\quad$ saturação efetiva; $\mathrm{S}_{\mathrm{e}}=\left(\mathrm{S}_{\mathrm{r}}-\mathrm{S}_{\mathrm{ru}}\right) /\left(\mathrm{S}_{\mathrm{rs}}-\mathrm{S}_{\mathrm{ru}}\right) ; \mathrm{e}$

$\mathrm{S}_{\mathrm{rs}}$ : $\quad$ saturação de campo;

2.1.5.3 COEFICIENTE DE CONDUTIVIDADE HIDRÁULICA SATURADA E NÃO SATURADA A PARTIR DE TÉCNICAS DE ENSAIO DE CAMPO

Há uma diversidade de opções de ensaios de campo para determinação da condutividade hidráulica dos solos. Estes ensaios podem ser feitos em furos de sondagem, em poços ou em cavas; aproveitando piezômetros e utilizando equipamentos e arranjos especiais, como os infiltrômetros (Vilar, 1997).

Segundo Trautwein e Boutwell (1994) in Daniel \& Stephen(1994), dos diferentes tipos de ensaios, duas são as técnicas mais usadas: infiltrômetro de anel duplo, e os ensaios em furos de sondagem.

Uma alternativa de ensaio que permite estimar a condutividade hidráulica saturada e a função condutividade hidráulica não saturada, a partir de uma lei de variação dessa função, é o ensaio realizado com o permeâmetro Guelph. Trata-se de um ensaio em regime permanente, realizado em furos de sondagem, onde pequenas cargas hidráulicas são mantidas constantes graças a um tubo de Mariotte.

\subsubsection{PERMEÂMETRO GUELPH}

O permeâmetro Guelph foi desenvolvido por Reynolds \& Elrick (1983), e aperfeiçoado por Reynolds \& Elrick (1985), na University of Guelph, Canada.

\section{a) Descrição do Permeâmetro}


Consiste em um permeâmetro de carga constante que trabalha sob o principio do tubo de Mariotte, e permite determinar inicialmente a condutividade hidráulica saturada, o potencial matricial de fluxo, e a sorção do solo no campo.

A partir da condutividade hidráulica saturada $\left(\mathrm{K}_{\mathrm{s}}\right)$ e do potencial matricial de fluxo $\left(\phi_{\mathrm{gm}}\right)$ estimados com o permeâmetro no campo, torna-se possível avaliar a função da condutividade hidráulica não saturada $\mathrm{K}(\psi)$, com uma lei de variação dessa função proposta por Gardner (1958) e utilizada por Reynolds e Rick (1985) neste método.

\section{b) Equipamentos:}

Na Figura 2.14 é mostrado o permeâmetro Guelph e suas partes.

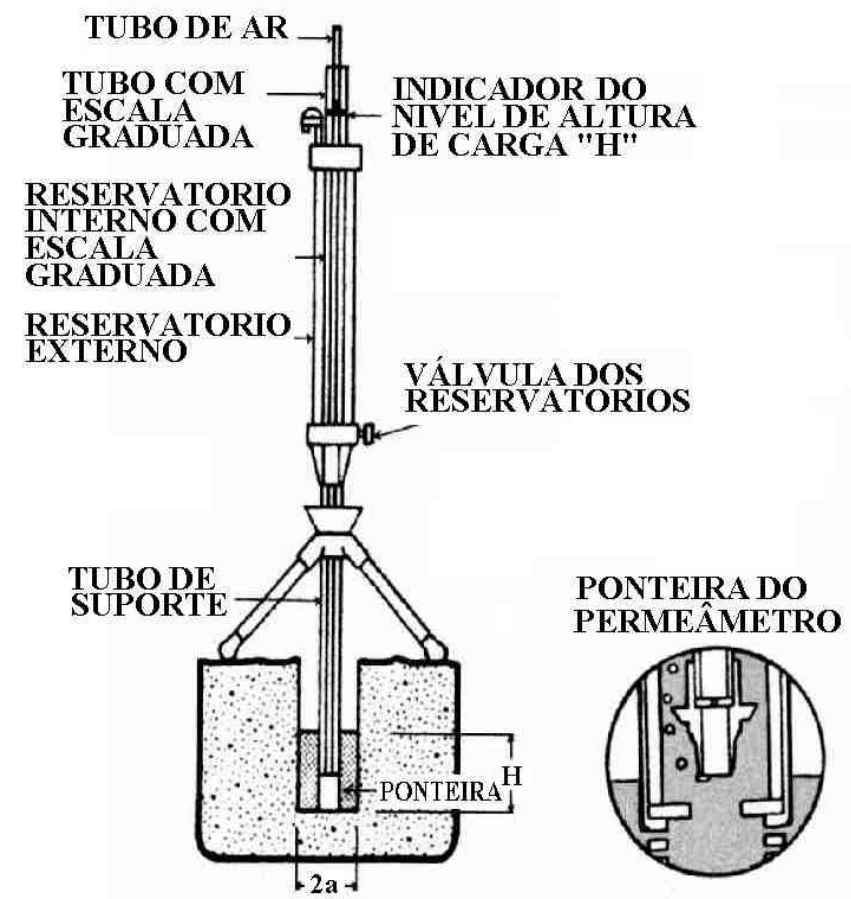

FIGURA 2.14- Esquema do Permeâmetro Guelph.

Os tubos estão conectados entre si para conduzir água desde os reservatórios até o furo de sondagem mantendo uma carga constante de água no furo através do sistema do tubo de Mariotte.

O reservatório em conjunto (interno e externo), consta de um sistema de depósito de água e de medição da vazão do fluxo de água. Nos ensaios em solos com permeabilidades baixas, utiliza-se o reservatório interno para propiciar adequada vazão e para realizar as leituras. Para solos com permeabilidades altas, a combinação dos dois reservatórios é o mais adequado; para ambos os casos, a vazão de infiltração é medida na escala graduada no tubo interno. 
A ponteira do permeâmetro serve como dissipador de energia da saída de água, controladas por saídas nervuradas, que evitam também a erosão do solo no furo de sondagem.

\section{c) Princípios teóricos para ensaios com o permeâmetro Guelph}

Philip (1985) apresenta uma análise onde inclui os efeitos de fluxo saturado e não saturado. Este modelo teórico para o fluxo não saturado está baseado na equação empírica da função condutividade hidráulica desenvolvida por Gardner (1958), e faz uso do parâmetro exponencial $\alpha\left[\mathrm{L}^{-1}\right]$, denominado por Philip como "sorção", que caracteriza as propriedades de sucção matricial, dependendo do tipo de solo.

Assim, o modelo teórico está representado por:

$$
\begin{gathered}
\mathrm{Q}=\mathrm{K}_{\mathrm{s}} \mathrm{a}^{2}\left(\mathrm{R}^{2}-1\right)^{0.5}\left(\frac{4.11 \mathrm{R}\left(1-\mathrm{R}^{-2}\right)}{\ln \left[\mathrm{R}+\left(\mathrm{R}^{2}-1\right)^{0.5}\right]-\left(1-\mathrm{R}^{-2}\right)^{0.5}}+\frac{4.28}{\mathrm{~A} \ln \left[\mathrm{R}+\left(\mathrm{R}^{2}-1\right)^{0.5}\right]}\right) \\
\mathrm{R}=\mathrm{H} / \mathrm{a} \\
\mathrm{A}=\alpha \mathrm{a} / 2
\end{gathered}
$$

Onde "a" é o raio do furo no solo, "H" é a altura de carga e " $\alpha$ " é o numero de sorção.

Posteriormente a teoria foi estendida por Reynolds e Elrick (1985), para levar em conta os efeitos do fluxo não saturado em $\mathrm{K}_{\mathrm{s}}$, e como conseqüência do novo modelo teórico, foram também obtidos outros parâmetros adicionais que serão analisados posteriormente.

Neste método, o modelo teórico está baseado na equação de Richards (1931), para fluxo permanente num furo cilíndrico. O fluxo permanente é definido por uma equação onde a vazão Q é composta por duas parcelas, sendo que a primeira corresponde ao fluxo saturado e a segunda ao fluxo não saturado (Reynolds e Elrick, 1985), dados pela equação:

$$
\begin{aligned}
& \mathrm{Q}=\mathrm{AK} K_{\mathrm{s}}+\mathrm{B} \phi_{\mathrm{gm}} \\
& \mathrm{A}=\frac{2 \pi \mathrm{H}^{2}}{\mathrm{C}}+\pi \mathrm{a}^{2} \\
& \mathrm{~B}=\frac{2 \pi \mathrm{H}}{\mathrm{C}}
\end{aligned}
$$

Onde $\phi_{\mathrm{gm}}\left[\mathrm{L}^{2} \mathrm{~T}^{-1}\right]$ é o denominado "Potencial matricial de fluxo", e C[1] um parâmetro denominado "fator de forma", que depende da relação H/a e do tipo de solo.

Graficamente (Figura 2.15), a Soilmoisture Equipment Corp (1986) fornece o fator C para três classes de solos (textura e macroporosidade). 


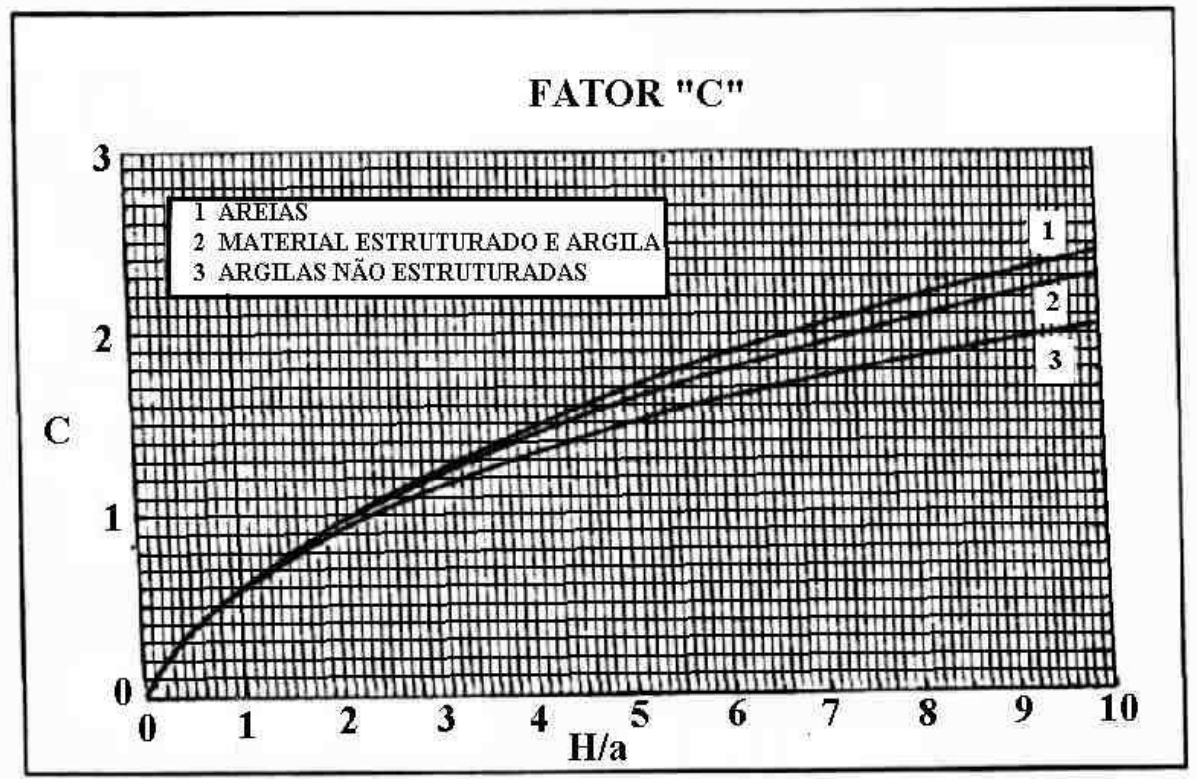

FIGURA 2.15- Gráfico do fator de forma "C".

Os componentes saturados e não saturados da equação (2.14), foram deduzidos a partir das superfícies dos bulbos saturados e não saturados que se formam no solo ao redor do furo de sondagem durante a execução de um ensaio (Elrick et al. 1989), e que estão esquematizados na Figura 2.16.

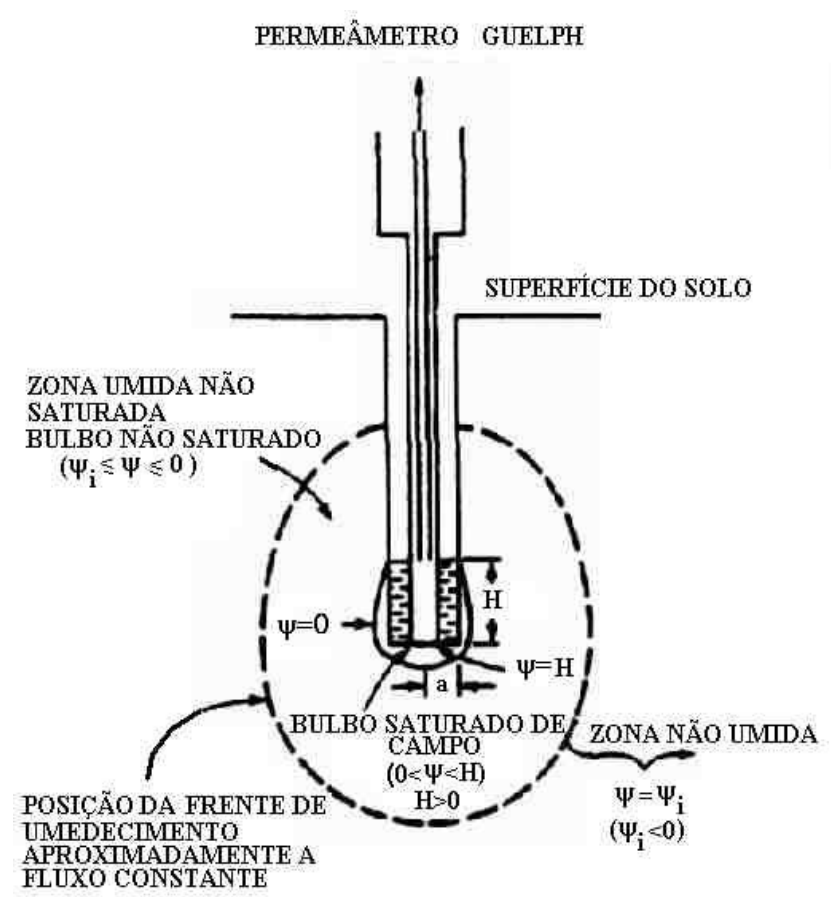

FIGURA 2.16- Bulbo saturado e não saturado ao redor do furo de sondagem durante o ensaio a carga constante. 
Segundo ELRICK et al, 1989, durante o ensaio o bulbo maior úmido (mas não saturado) migra externamente partindo do bulbo saturado, que é representado na equação pelo segundo termo. No segundo termo o efeito da sucção matricial é incorporado no potencial matricial de fluxo $\phi_{\mathrm{Gm}}$.

A equação que descreve o potencial matricial de fluxo foi definida a partir de GARDNER (1958), por:

$$
\phi_{\mathrm{Gm}}=\int_{\psi \mathrm{i}}^{0} \mathrm{~K}(\psi) \mathrm{d} \psi \quad \Psi \mathrm{i} \leq \Psi \leq 0
$$

onde $\Psi[\mathrm{L}]$ é a carga de pressão de água no solo, e $\mathrm{K}(\Psi)\left[\mathrm{LT}^{-2}\right]$ é a função condutividade hidráulica.

Nesta equação o limite superior da integração $(\Psi=0)$ e o inferior $(\Psi=\Psi i)$, referemse ao limite do bulbo saturado e não saturado respectivamente. Dentro do bulbo saturado a pressão de água no solo é $\Psi>\mathbf{0}$, e dentro do bulbo não saturado, $\Psi<\mathbf{0}$, que corresponde à sucção matricial do solo.

A equação empírica exponencial utilizada por REYNOLDS e ELRICK (1985), para determinar a função condutividade hidráulica não saturada fica expressa como:

$$
\int_{\mathrm{Ki}}^{\mathrm{K}_{\mathrm{s}}} \frac{1}{\mathrm{~K}(\psi)} \mathrm{dK}(\psi)=\int_{\psi i}^{0} \alpha \cdot \mathrm{d} \psi
$$

Resolvendo obtém-se:

$$
\mathrm{K}(\psi)=\mathrm{K}_{\mathrm{s}} \cdot \mathrm{e}^{\alpha \psi} \quad \alpha>0 \quad \psi<0
$$

Onde:

$\mathrm{K}_{\mathrm{s}} \quad$ : condutividade hidráulica saturada de campo $\left(\mathrm{LT}^{-1}\right)$;

e : 2,71828;

$\psi \quad$ : sucção matricial do solo (L); e

$\alpha \quad$ : constante que depende das características do solo $\left(\mathrm{L}^{-1}\right)$ (Bresler, 1978);

A equação (2.19), pode ser substituída na equação (2.17), o que resulta:

$$
\phi_{\mathrm{gm}}=\frac{\mathrm{K}_{\mathrm{s}}}{\alpha}\left[1-\mathrm{e}^{\alpha \psi \mathrm{i}}\right]
$$


Segundo SCOTTER et al (1982), considerando que $\exp \left(\alpha \Psi_{\mathrm{i}}\right)<<1$ para solos relativamente secos $\left(\Psi_{\mathrm{i}}<-10 \mathrm{kPa}\right)$ em estado natural, a expressão pode ser ainda reduzida para:

$$
\alpha=\mathrm{K}_{\mathrm{s}} / \phi_{\mathrm{gm}}
$$

Assim o parâmetro $\alpha$ é reduzido a uma relação entre a condutividade hidráulica saturada de campo $\mathrm{K}_{\mathrm{s}}$ e o potencial matricial de fluxo $\phi_{\mathrm{gm}}$, ambos obtidos de campo através do permeâmetro.

d) Procedimentos para solução da equação de fluxo a regime constante para

\section{o Permeâmetro Guelph}

Tem-se diferentes técnicas para obtenção dos parâmetros $\left(\mathrm{K}_{\mathrm{s}}, \phi_{\mathrm{gm}} \mathrm{e} \alpha\right)$, entre eles:

- uma altura de carga (Elrick et al., 1989);

- duas alturas de carga (Reynolds e Elrick 1985);

- duas alturas de carga com escala heterogênea (Elrick et al. 1989); e

- método de Philip (1985).

A seguir será discutido o método de duas alturas de carga, método que foi utilizado no presente trabalho.

\section{Técnica de duas alturas de carga:}

Nesta forma de ensaio, duas medidas de vazão são efetuadas para duas alturas de carga diferentes. Com isto é possível obter $\mathrm{K}_{\mathrm{s}}, \phi_{\mathrm{gm}}$ e o parâmetro $\alpha$.

O equacionamento proposto por REYNOLDS e ELRICK (1985), para este caso é o seguinte:

$$
\begin{aligned}
& \mathrm{Q}_{1}=\mathrm{A}_{1} \mathrm{~K}_{\mathrm{s}}+\mathrm{B}_{1} \phi_{\mathrm{gm}} \\
& \mathrm{Q}_{2}=\mathrm{A}_{2} \mathrm{~K}_{\mathrm{s}}+\mathrm{B}_{2} \phi_{\mathrm{gm}} \\
& \left.\mathrm{A}_{1}=\left[\left(2 \pi \mathrm{H}_{1}{ }^{2} / \mathrm{C}_{1}\right)+\pi \mathrm{a}^{2}\right)\right] \\
& \left.\mathrm{A}_{2}=\left[\left(2 \pi \mathrm{H}_{2}{ }^{2} / \mathrm{C}_{2}\right)+\pi \mathrm{a}^{2}\right)\right] \\
& \mathrm{B}_{1}=\left(2 \pi \mathrm{H}_{1} / \mathrm{C}_{1}\right)
\end{aligned}
$$


$\mathrm{B}_{2}=\left(2 \pi \mathrm{H}_{2} / \mathrm{C}_{2}\right)$

$\mathrm{H}_{2}>\mathrm{H}_{1} ; \mathrm{Q}_{2}>\mathrm{Q}_{1}$

$\mathrm{C}_{1}$ e $\mathrm{C}_{2}$ são obtidos da Figura 2.15.

A solução das equações 2.28 e 2.29 , permitem obter $\mathrm{K}_{\mathrm{s}}$ e $\phi_{\mathrm{gm}}$.

$$
\begin{aligned}
& \mathrm{K}_{\mathrm{s}}=\mathrm{G}_{2} \mathrm{Q}_{2}-\mathrm{G}_{1} \mathrm{Q}_{1} \\
& \phi_{\mathrm{gm}}=\mathrm{J}_{1} \mathrm{Q}_{1}-\mathrm{J}_{2} \mathrm{Q}_{2}
\end{aligned}
$$

Onde:

$$
\begin{aligned}
& \mathrm{G}_{2}=\frac{\mathrm{H}_{1} \mathrm{C}_{1}}{\pi\left(2 \mathrm{H}_{1} \mathrm{H}_{2}\left(\mathrm{H}_{2}-\mathrm{H}_{1}\right)+\mathrm{a}^{2}\left(\mathrm{H}_{1} \mathrm{C}_{2}-\mathrm{H}_{2} \mathrm{C}_{1}\right)\right)} \\
& \mathrm{G}_{1}=\mathrm{G}_{2} \frac{\mathrm{H}_{2} \mathrm{C}_{1}}{\mathrm{H}_{1} \mathrm{C}_{2}} \\
& \mathrm{~J}_{1}=\frac{\left(2 \mathrm{H}_{2}^{2}+\mathrm{a}^{2} \mathrm{C}_{2}\right) \mathrm{C}_{1}}{2 \pi\left[2 \mathrm{H}_{1} \mathrm{H}_{2}\left(\mathrm{H}_{2}-\mathrm{H}_{1}\right)+\mathrm{a}^{2}\left(\mathrm{H}_{1} \mathrm{C}_{2}-\mathrm{H}_{2} \mathrm{C}_{1}\right)\right]} \\
& \mathrm{J}_{2}=\mathrm{J}_{1} \frac{\mathrm{C}_{2}\left(2 \mathrm{H}_{1}^{2}+\mathrm{a}^{2} \mathrm{C}_{1}\right)}{\mathrm{C}_{1}\left(2 \mathrm{H}_{2}^{2}+\mathrm{a}^{2} \mathrm{C}_{2}\right)}
\end{aligned}
$$

A Tabela 2.5 mostra valores do parâmetro $\alpha$ sugeridos por ELRICK et al (1989).

TABELA 2.5 - Parâmetros $\alpha$ sugeridos por ELRICK et al (1989).

\begin{tabular}{|l|c|}
\hline$\alpha\left(\mathrm{cm}^{-1}\right)$ & TIPO DE SOLO \\
\hline 0.01 & - Argilas compactas (aterro, liners, sedimentos lacustres e marinhos). \\
\hline 0.04 & - Solos de textura fina, principalmente sem macroporos e fissuras. \\
\hline 0.12 & - Argilas até areias finas com alto a moderada quantidade de macroporos e fissuras. \\
\hline 0.36 & - Areias grossas, inclui solos com macroporos e fissuras. \\
\hline
\end{tabular}

Nesta Tabela REYNOLDS \& ELRICK (1985), sugerem valores de $\alpha$, considerando a textura e a estrutura (macroporos, fissuras) do solo. Os valores estão baseados em observações das variações de $\alpha$ obtidos em estudos de campo, e segundo o autor estas categorias podem mudar, quanto existirem maiores informações disponíveis. 


\subsubsection{RESISTÊNCIA AO CISALHAMENTO EM SOLO NÃO SATURADO}

\subsubsection{INTRODUÇÃO}

Muitos dos problemas em Geotecnia, tais como capacidade de carga, empuxo de terra em estruturas de contenção e estabilidade de taludes, estão relacionadas diretamente com a resistência ao cisalhamento dos solos e esta, por sua vez, está relacionada ao estado de tensões efetivas ao qual o solo esta submetido.

A resistência ao cisalhamento de um solo saturado é geralmente descrita utilizando-se o critério de Mohr Coulumb e o conceito de tensões efetivas proposto por Terzaghi.

$$
\tau=\mathrm{c}^{\prime}+\left(\sigma-\mathrm{u}_{\mathrm{w}}\right) \operatorname{tg} \phi
$$

Onde $\tau$ é a resistência ao cisalhamento na ruptura; c' é a coesão efetiva do solo; $\sigma$ é a tensão normal total e $\phi$ ' é o angulo de atrito interno do solo.

O estado tencional de um solo não saturado, de um ponto de vista microestrutural é resultado das diferentes solicitações às quais o solo é submetido, assim como da natureza e propriedades de suas fases componentes (fase sólida, fases líquida e gasosa e interações entre estas fases). A integração destes estados de tensão em cada ponto de uma determinada seção de solo não saturado irá resultar no estado de tensões do solo, compreendido ou medido de maneira externa à dada seção. Conforme pode-se notar, a resistência ao cisalhamento de um solo não saturado será dependente de uma serie de fatores e interações, não podendo ser perfeitamente representada pela expressão 2.34 .

\subsubsection{RESISTÊNCIA AO CISALHAMENTO EM SOLO NÃO SATURADO}

A realização de ensaios triaxiais ou de cisalhamento direto em amostras saturadas de solo, permite conhecer somente um aspecto de seu comportamento, que é a sua resistência mínima. Deve-se ter em conta, contudo, que o grau de saturação dos solos em campo pode variar grandemente, e que o conhecimento da variação da resistência associada às mudanças no seu teor de umidade (ou no valor de sucção atuante) conduzirá a um conhecimento mais completo de seu comportamento. No estudo da resistência ao cisalhamento dos solos não saturados, a influência da variação do teor de umidade (ou grau de saturação) é estudada de preferência através da sucção, pelas seguintes razões (Juca 1990):

A sucção pode variar com o estado de tensões a que está submetido o solo, mesmo que o teor da umidade se mantenha constante. 
Em solos compactados em um mesmo teor de umidade, a sucção matricial estará influenciada pela estrutura, e portanto também representa o tipo e energia de compactação que foi utilizada.

Nas relações estabelecidas diretamente com a sucção matricial o efeito da histerese é menos pronunciado que nas relações entre os parâmetros do solo e o teor de umidade.

De forma geral, o efeito da sucção matricial na resistência pode-se considerar como um incremento na rigidez do solo, produzido pela ação intergranular que é gerada, tendendo a manter mais fortemente unidas as partículas do solo. A resistência ao cisalhamento do solo cresce com o incremento da sucção matricial, até um valor máximo, a partir do qual pode-se produzir uma ligeira diminuição na resistência até o solo ficar completamente seco. Este último aspecto é geralmente observado somente no caso de solos puramente arenosos (Juca 1990). Fredlund \& Rahardjo (1993) apresentam um resumo dos principais trabalhos publicados sobre o tema. Uma das primeiras e mais utilizadas expressões para relacionar a resistência ao cisalhamento com a sucção matricial se deve a Bishop et al.(1960), a qual utiliza o critério de ruptura de Mohr-Coulomb e a expressão proposta por Bishop (1959) para obtenção da tensão efetiva atuando em um solo não saturado.

$$
\tau=\mathrm{c}^{\prime}+\left(\sigma-\mathrm{u}_{\mathrm{a}}+\chi\left(\mathrm{u}_{\mathrm{a}}-\mathrm{u}_{\mathrm{w}}\right)\right) \operatorname{tg} \phi^{\prime}
$$

Onde $\chi$ é um Parâmetro que depende do grau de saturação, tipo de solo e de efeitos de histerese decorrentes da secagem ou do umedecimento do solo.

Fredlund et al (1978) propuseram escrever a resistência ao cisalhamento dos solos em termos de variáveis de estado de tensões. Segundo estes autores, a melhor combinação de variáveis de estado de tensões para se obter a resistência ao cisalhamento do solo seria:

$$
\tau=c^{\prime}+\left(\sigma-u_{a}\right) \operatorname{tg} \phi^{\prime}+\left(u_{a}-u_{w}\right) \operatorname{tg} \phi^{b}
$$

Onde $\phi^{\mathrm{b}}$ é o ângulo de atrito do solo em relação à sucção. Algumas observações podem ser feitas da proposta de Fredlund et al. (1978):

a) o ângulo de atrito interno do solo é suposto constante com a sucção matricial;

b) a resistência ao cisalhamento do solo cresce linearmente com a sucção matricial;

c) envoltória de ruptura plana (Figura 2.17); e 
d) como o ângulo de atrito interno é suposto constante com a sucção matricial, todo o ganho de resistência ao cisalhamento do solo se refletirá em um acréscimo de coesão, de modo que a coesão do solo não saturado pode se quantificar como segue:

$$
c=c^{\prime}+\left(u_{a}-u_{w}\right) \operatorname{tg} \phi^{b}
$$

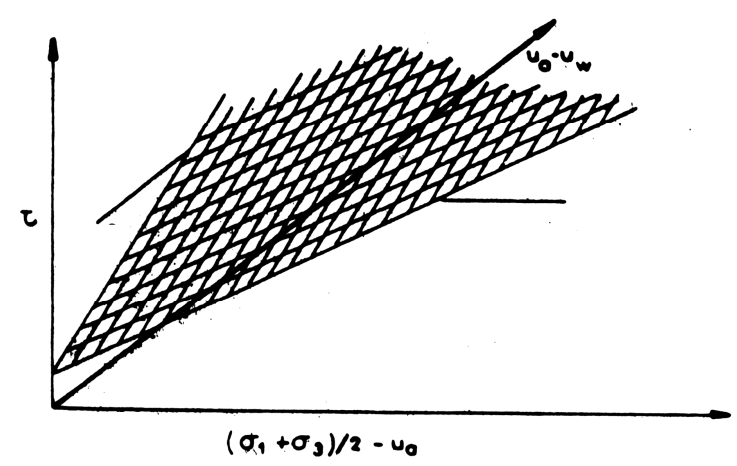

FIGURA 2.17- Representação gráfica da expressão de Fredlund et al. (1978).

Diversos autores, entre eles Fredlund et al.(1978), Gulathi \& Satija (1981) e Ho \& Fredlund (1982) apresentam resultados de ensaios triaxiais com sucção matricial controlada onde o uso da equação 2.36 é justificado. Segundo estes autores, o valor de $\phi^{\mathrm{b}}$ é em geral menor que $\phi^{\prime}$, indicando que um incremento no valor da variável de tensões $\left(\sigma-\mathrm{u}_{\mathrm{a}}\right)$ tem uma maior contribuição na resistência do solo que um mesmo incremento em $\left(\mathrm{u}_{\mathrm{a}}-\mathrm{u}_{\mathrm{w}}\right)$. A validade da equação 2.36 tem sido contudo contestada por diversos autores. Um aspecto chama a atenção quando comparamos as equações (2.36) e (2.37). Desta comparação notamos que $\operatorname{tg} \phi^{\mathrm{b}}=\chi \operatorname{tg} \phi^{\prime}$. Ora, se $\chi=1$ para os solos saturados, deve-se esperar que $\phi^{\mathrm{b}}$ seja próximo a $\phi^{\prime}$ quando o solo esteja no campo das baixas sucções matriciais e que $\phi^{\mathrm{b}}$ tenda para zero à medida em que a sucção matricial aumente e o solo se distancie da sua condição de saturado. Esta observação foi feita por Wood (1979), segundo o qual a equação 2.37 considera que os acréscimos de coesão não são influenciados pela não saturação no solo.

Gulhati \& Satija (1981) realizando ensaios triaxiais em amostras naturais e compactadas, verificaram que o parâmetro $\chi$, dependia de diversos fatores, como o histórico e magnitude das tensões aplicadas, a estrutura dos solos e a histerese. Foram encontrados eventualmente valores negativos de $\chi$ para solos colapsíveis, dois valores de $\chi$ distintos para o mesmo grau de saturação e mesmo solo e ainda valores superiores a unidade, contrariando a hipótese inicial de que este parâmetro seria função unicamente do grau de saturação. 
A Figura 2.18 apresenta a variação dos parâmetros c e $\phi$ com a sucção matricial obtida a partir da realização de ensaios triaxiais com sucção matricial controlada por Delage et al. (1987) em uma argila. Escario \& Saez (1986) mostram ser inadequada a adoção de um valor de $\phi^{\mathrm{b}}$ constante com a sucção matricial. A Figura 2.19 mostra claramente a variação de $\phi^{\mathrm{b}}$, principalmente para pequenos valores de sucção matricial. Também para altos valores de sucção matricial o valor de $\phi^{\mathrm{b}}$ variará, pois o efeito da sucção matricial na resistência ao cisalhamento dependerá do tipo de solo e do valor mínimo de grau de saturação alcançado.

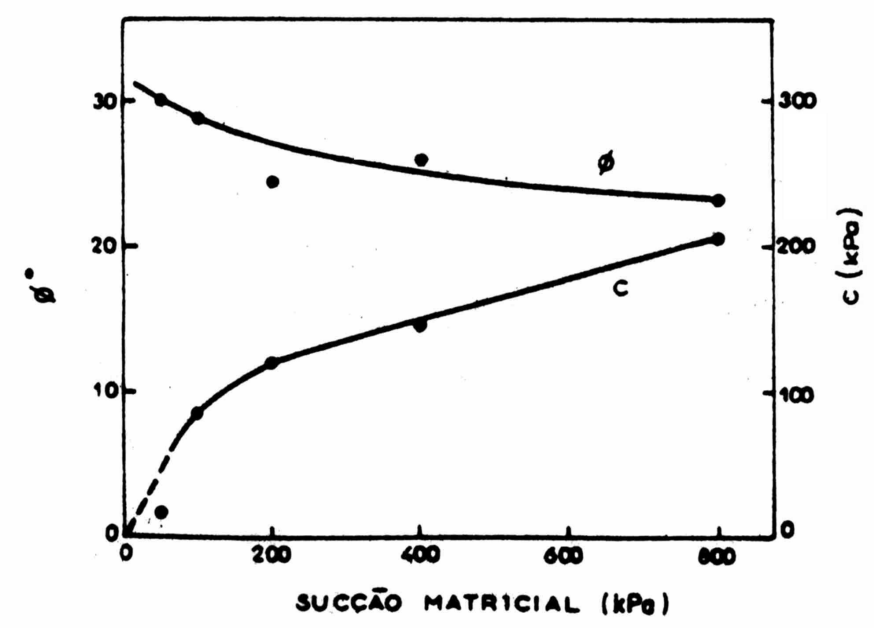

FIGURA 2.18- Variação da coesão e do angulo de atrito interno em função da sucção matricial (Delage et al., 1987).

No caso das areias esta influência tende a desaparecer com a secagem completa do solo. Isto explica porque em alguns casos existe um valor máximo de resistência entre os estados saturado e completamente seco do solo. Delage et al. (1987) também obtém valores de $\phi^{\mathrm{b}}$ variáveis com a sucção matricial. A Figura 2.20 mostra gráficos semelhantes apresentados por Escario \& Jucá (1989).

Conforme pode-se observar destas Figuras, embora a sucção matricial desempenhe uma clara função no incremento da coesão do solo, sua influencia no ângulo de atrito interno é bastante controvertida. Apoiando-se nestas constatações, vários autores têm estudado a influencia da sucção matricial no intercepto de coesão do solo, fazendo-se $\phi$ ' constante com a sucção matricial e igual ao valor medido a partir de ensaios triaxiais realizados em amostras saturadas (Teixeira, 1996). Escario (1988) analisa resultados experimentais de resistência ao cisalhamento obtidos a partir da realização de ensaios com sucção matricial controlada correlacionando-os com a sucção matricial através de uma elipse de grau 2,5. No ajuste da equação proposta as seguintes observações devem ser asseguradas: 


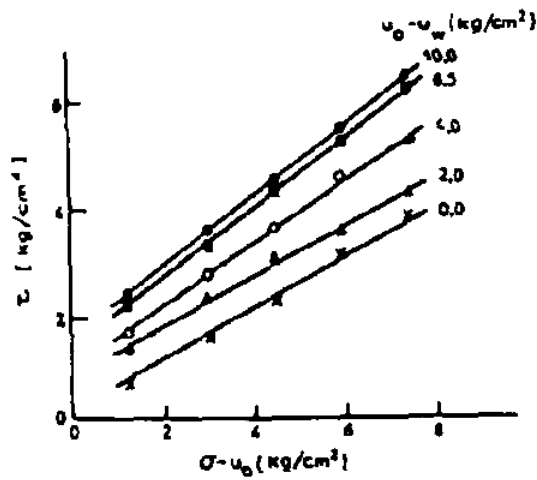

(a)

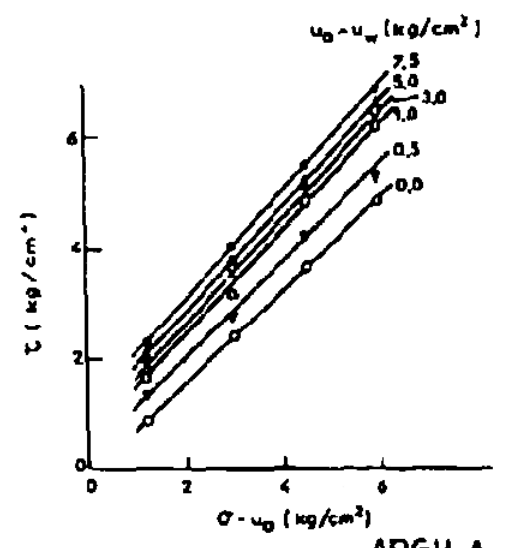

(0)

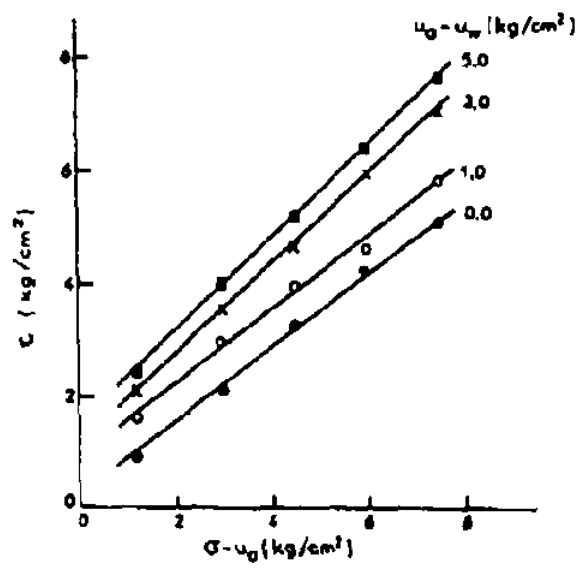

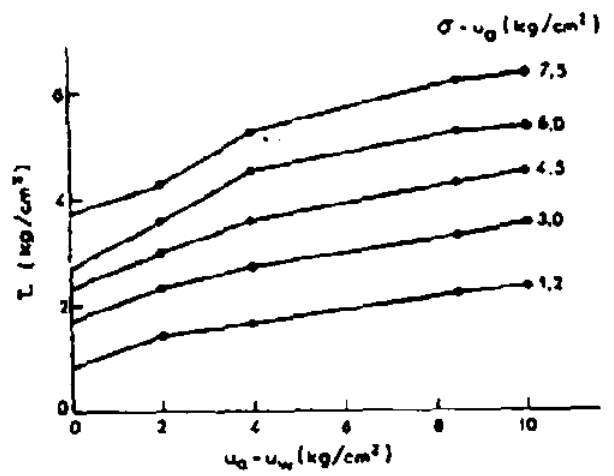

(b)

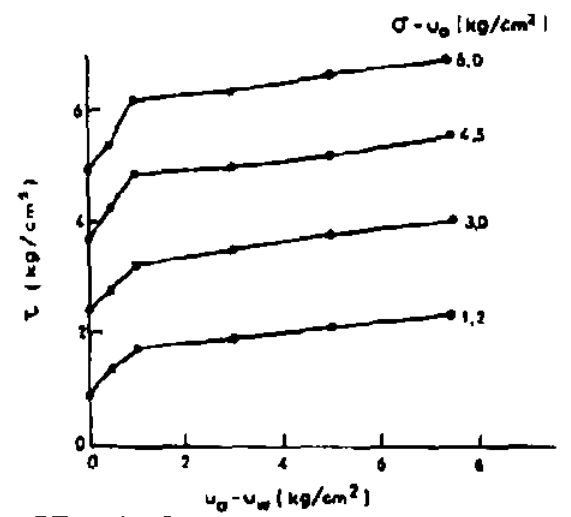

(b)

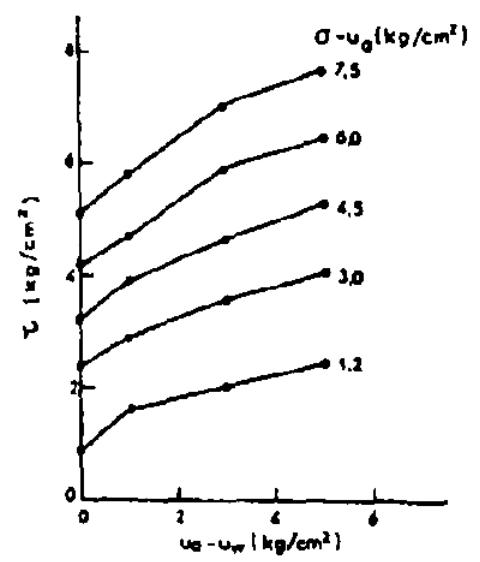

ARGILA VERMELHA DE GUADALIX DE LA SIERRA

FIGURA 2.19- a)Resistência ao cisalhamento x tensão normal para diferentes valores de sucção matricial b)Resistência ao cisalhamento x sucção matricial para diferentes valores de tensão normal,

Escario \& Saez (1986). 

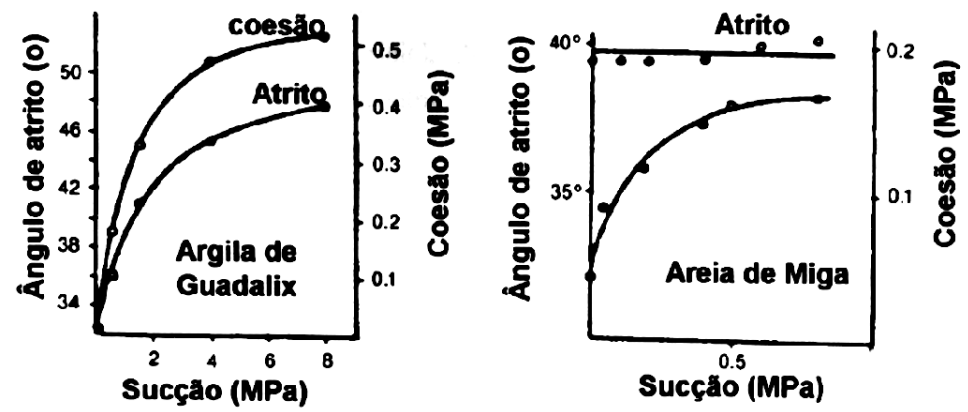

FIGURA 2.20- Variações de c e $\phi$ com a sucção para dois solos distintos. Escario \& Jucá (1989).

- sua tangente na origem $\left(\mathrm{u}_{\mathrm{a}}-\mathrm{u}_{\mathrm{w}}=0\right)$ deve possuir uma inclinação igual a $\phi^{\prime}$. Em outras palavras, deve-se assegurar que $\phi^{\mathrm{b}}=\phi^{\prime}$ para $\left(\mathrm{u}_{\mathrm{a}}-\mathrm{u}_{\mathrm{w}}\right)=0$; e

- valor de resistência ao cisalhamento do solo deve alcançar um valor máximo para um valor finito de sucção matricial.

Abramento (1988) admite que a relação entre coesão e sucção matricial pode ser representada por uma função potencial com exponente menor do que a unidade. Fonseca (1991) atenta para a não linearidade das relações entre a resistência ao cisalhamento e a sucção matricial.

Rohm (1992) apresenta resultados de ensaios triaxiais realizados em um colúvio arenoso indeformado nos quais obtém-se valores de $\phi^{\prime}$ crescentes com a sucção matricial (de 27 a 32 aproximadamente, para valores de sucção matricial variando entre 0 e $400 \mathrm{kPa}$ ). O intercepto de coesão do solo apresenta valores crescentes com a sucção matricial até valores de sucção matricial de cerca de 200kPa. A partir deste valor, acréscimos de sucção matricial pouco influenciaram nos valores de c'. Ainda segundo este autor, a relação entre resistência ao cisalhamento e a sucção matricial segue uma lei hiperbólica.

Texeira (1996) apresenta resultados de ensaios triaxiais realizados no mesmo solo que Rohm (1992), estando este em uma condição compactada. Os resultados obtidos indicam valores de $\phi^{\prime}$ praticamente constantes com a sucção matricial e valores de c' variando com a sucção matricial conforme uma lei hiperbólica. Ainda segundo Texeira (1996) para baixos valores de sucção matricial é possível encontrar-se $\phi^{\mathrm{b}}>\phi^{\prime}$.

Fredlund et al (1987) admitem a não linearidade da resistência ao cisalhamento com a sucção matricial. Os autores ensaiando um solo de origem glacial em cisalhamento direto encontraram valores de $\phi^{\mathrm{b}}$ decrescentes com a sucção matricial. Ainda segundo Fredlund et al. (1987), para baixos valores de sucção matricial, tem-se aproximadamente $\phi^{\mathrm{b}}=\phi^{\prime}$. 
Gan \& Fredlund (1995) apresentam resultados de ensaios triaxiais e de cisalhamento direto realizados em dois solos saprolíticos, ambos possuindo importantes vínculos inter partículas, ensaiados em condições saturadas e com sucção matricial controlada. Os resultados apresentados em termos de resistência ao cisalhamento de pico apresentam uma envoltória curvilínea para baixos valores de tensão normal e linear para altos valores. A resistência ao cisalhamento cresce com a sucção matricial aplicada, atingindo valores máximos para valores de sucção matricial entre 75 e 100kPa. Ainda segundo estes autores, o caráter não linear das relações entre $\tau$ e sucção matricial advém da curva característica de sucção matricial do solo.

Drumright \& Nelson (1995) realizaram ensaios triaxiais com sucção matricial controlada em uma areia proveniente de rejeitos de uma mina de cobre, em múltiplos estágios, chegando a valores de resistência ao cisalhamento variando de maneira não linear com a sucção matricial.

Com base nos estudos até aqui apresentados, as seguintes conclusões podem ser expostas a respeito da resistência ao cisalhamento de solos não saturados:

- a resistência ao cisalhamento se relaciona de maneira não linear com a sucção matricial: para baixos valores de sucção matricial tem-se aproximadamente $\phi^{\mathrm{b}}=\phi^{\prime}$. Os valores de $\phi^{\mathrm{b}}$ decrescem com o valor da sucção matricial, de modo que a resistência ao cisalhamento do solo tende a um valor máximo para altos valores de $\left(\mathrm{u}_{\mathrm{a}}-\mathrm{u}_{\mathrm{w}}\right)$. Alguns solos arenosos podem apresentar valores de resistência ao cisalhamento decrescentes para baixos valores de saturação; e

- o intercepto de coesão aparente do solo apresenta valores crescentes com a sucção matricial. As relações entre $\mathrm{c}$ e $\left(\mathrm{u}_{\mathrm{a}}-\mathrm{u}_{\mathrm{w}}\right)$ possuem formas assemelhadas àquelas propostas para a resistência ao cisalhamento. A sucção matricial parece não apresentar uma influência definida no valor do ângulo de atrito interno do solo.

\subsubsection{ENSAIO DE COMPRESSÃO TRIAXIAL COM CONTROLE DE SUCÇÃO MATRICIAL}

A adaptação fundamental presente nas câmaras de ensaio triaxial usadas por Bishop et al (1960), Bishop e Donald (1961), Bishop e Henkel (1962), dentre outros, é a utilização de um elemento de alta pressão de entrada de ar, junto ao corpo de prova, que permite controlar ou medir a pressão da água de magnitudes negativas em relação à atmosférica. Comum também, a todos estes equipamentos é o emprego de um elemento poroso que permita a medida ou controle da pressão de ar no solo. 


\section{Tempo de equilíbrio}

Os elementos de alta pressão de entrada de ar usados no estudo de solos não saturados são de baixa permeabilidade, Associados a esta característica estão dois problemas: a) o tempo necessário para se atingir a sucção matricial inicial de ensaio e, b) o tempo de equilíbrio da sucção matricial durante o ensaio geotécnico.

O primeiro problema pode ser resolvido com um maior número de aparelhos, de tal forma que os ensaios obedeçam a um cronograma que permita otimizar o uso dos recursos disponíveis. O segundo entrave deve ser contornado com a adoção de velocidades de ensaio que permitam o reequilibro da sucção matricial em todo corpo de prova.

\section{Elementos de alta pressão de entrada de ar}

$\mathrm{Na}$ Tabela 2.6 observam-se as características das pedras porosas utilizadas pelos autores nos estudos com solos não saturados.

TABELA 2.6- Características das pedras porosas usadas por Bishop et al (1960).

\begin{tabular}{|lcc|}
\hline Características & \multicolumn{2}{c|}{ pedras porosas } \\
\hline & Aerox “Celloton” & Doulton \\
& Grade & Grade P6A \\
\hline Porosidade (\%) & 46 & 23 \\
p. de borbulhamento (psi) & 30 & 22 \\
Permeabilidade (cm/s) & $2.9 \times 10^{-6}$ & $2.1 \times 10^{-7}$ \\
\hline
\end{tabular}

\section{Tipos de ensaio}

Na Tabela 2.7 mostram-se os vários tipos de ensaios triaxiais em solo não saturado, segundo Fredlund \& Rahardjo (1993).

TABELA 2.7- Ensaios Triaxiais para solos não saturados.

\begin{tabular}{|c|c|c|c|c|c|c|}
\hline \multirow[b]{2}{*}{ Tipos de ensaio } & \multirow[b]{2}{*}{$\begin{array}{c}\text { Consolidação } \\
\text { antes da ruptura }\end{array}$} & \multicolumn{2}{|c|}{ Drenagem } & \multicolumn{3}{|c|}{ Processo de ruptura } \\
\hline & & Ar & Água & $\mathbf{u}_{\mathrm{a}}$ & $\mathbf{u}_{\mathbf{w}}$ & $\Delta \mathbf{V}$ \\
\hline $\begin{array}{l}\text { Consolidado drenado } \\
\text { (CD) }\end{array}$ & Sim & Sim & Sim & $\mathrm{C}$ & $\mathrm{C}$ & M \\
\hline $\begin{array}{l}\text { Conteúdo de água constante } \\
\qquad(\mathrm{CW})\end{array}$ & Sim & Sim & Não & $\mathrm{C}$ & M & M \\
\hline $\begin{array}{l}\text { Consolidado não drenado } \\
\qquad(\mathrm{CU})\end{array}$ & Sim & Não & Não & M & M & - \\
\hline Não drenado & Não & Não & Não & - & - & - \\
\hline $\begin{array}{l}\text { Compressão não confinada } \\
\text { (UC) }\end{array}$ & Não & Não & Não & - & - & - \\
\hline
\end{tabular}

$\mathrm{M}=$ Medido, $\mathrm{C}=$ Controlado. 
No ensaio Consolidado Drenado (CD), o corpo de prova primeiro é consolidado e depois é cisalhado em condições drenadas. Geralmente é consolidado com pressão de confinamento isotrópico de $\sigma_{3}$ e pressões de ar e de água controladas, $u_{a}$ e $u_{w}$, respectivamente. Ao final do processo de consolidação, o corpo de prova tem uma pressão de confinamento de $\left(\sigma_{3}-u_{a}\right)$ e uma sucção matricial de $\left(\mathrm{u}_{\mathrm{a}}-\mathrm{u}_{\mathrm{w}}\right)$. Durante o cisalhamento as válvulas do ar e da água estão abertas, mas as pressões de ambas são mantidas constantes. A tensão desviadora $\left(\sigma_{1}-\sigma_{3}\right)$, é aplicada lentamente, e as pressões $\left(\sigma_{3}-u_{\mathrm{a}}\right)$ e $\left(\mathrm{u}_{\mathrm{a}}-\mathrm{u}_{\mathrm{w}}\right)$, são mantidas constantes durante o processo de cisalhamento.

No ensaio com conteúdo de água constante $(\mathrm{CW})$, o corpo de prova é primeiro consolidado e depois cisalhado, com a válvula de ar aberta e a válvula de água fechada. A fase de consolidação é igual ao ensaio $\mathrm{CD}$. Na fase de cisalhamento mantém-se a pressão de ar constante e a pressão de água variável.

No ensaio consolidado não drenado (CU), a fase de consolidação é igual ao ensaio $\mathrm{CD}$, e na fase de cisalhamento, mantém-se as válvulas de ar e água fechadas.

No ensaio não drenado não é feita a fase de consolidação e na fase de cisalhamento é mantida fechada as válvulas de ar e água.

O ensaio de compressão não confinada (UC), é um caso especial do ensaio não drenado, onde o confinamento aplicado e zero e a pressão de ar é equivalente à pressão atmosférica.

\subsection{ENGENHARIA GEOTÉCNICA EM SOLOS RESIDUAIS}

\subsubsection{INTRODUÇÃO}

$\mathrm{Na}$ engenharia geotécnica em solos residuais, um problema freqüente a analisar é a estabilidade de taludes, devido principalmente a instabilidade do solo causada pela redução da sua resistência, como conseqüência das características próprias do clima tropical.

O clima tropical apresenta-se comumente entre os trópicos de Câncer e Capricórnio, sendo suas características principais elevada temperatura, umidade e abundante precipitação. Estas características do clima tropical, produzem intensa intemperização da rocha, denominando-se ao material intemperizado comumente como solo residual.

$\mathrm{O}$ grau de intemperização da massa rochosa varia com a profundidade, formando-se o que se conhece como perfil de intemperização. No perfil de intemperização, o solo é categorizado comumente de forma simples como 'laterítico', 'saprolítico' e 'rocha' (Brand, 1985). 
Neste ítem serão abordados os conceitos de solo residual, os perfis de intemperização e a problemática de taludes em solo residual.

\subsubsection{SOLO RESIDUAL}

\subsubsection{DEFINIÇÃO}

Não existe uma definição universalmente aceita de solos residuais. Estes materiais são produto da intemperização in situ de rochas ígneas, sedimentares e metamórficas. O grau de intemperização da rocha varia com a profundidade. Este processo dá lugar a que os perfis de intemperização contenham desde o material rochoso, até o material completamente intemperizado, considerando-se o segundo pela engenharia geotécnica como "solo". Para os propósitos da engenharia, é difícil separar o "solo" do resto do perfil de intemperização, e o perfil inteiro trata-se então, como uma única entidade (Brand, 1985).

Em países tropicais, os materiais residuais são particularmente prevalecentes. A intemperização da camada rochosa tem acontecido, com a abundância de água e as temperaturas ambientais relativamente altas, que têm sido de importância nas mudanças químicas que aconteceram às rochas de origem. Para os propósitos do perfil de intemperização tropical, os materiais do solo às vezes categorizam-se simplesmente como 'laterítico', 'saprolítico e 'rocha' (Brand, 1985).

Em muitos países, existem extensos depósitos de material coluvionar junto com materiais residuais, como os cones de dejeção no pé do talude. O material coluvionar derivase da intemperização de qualquer rocha de origem que foi transportada pelo próprio peso. Possui muitas das características gerais do solo residual, particularmente no contexto do comportamento da engenharia. Devido que este material encontra-se geralmente como cobertura acima do perfil de rocha intemperizada, às vezes é difícil de distinguir entre material coluvionar e o material in situ. Para propósitos da engenharia geotécnica, pode-se agrupar o material coluvionar então, com os solos residuais.

Um resumo dos tipos de material considerados como "solo residual' em dezoito países foi realizado por Brand \& Phillipson (1985a). Da análise feita por estes pesquisadores concluiu-se:

- geralmente aceita-se que os solos residuais podem ser o resultado da intemperização de qualquer tipo de rocha; 
- inclui-se na categoria de 'solo residual' materiais que não são completamente intemperizados e que retêm a estrutura original da rocha de origem, os chamados saprolito ou solos saprolíticos; e

- o material coluvionar invariavelmente categoriza-se como 'solo residual' para propósitos da engenharia.

\subsubsection{CARACTERÍSTICAS ESPECIAIS DOS SOLOS RESIDUAIS}

De uma forma geral, os solos residuais são muito heterogêneos, difíceis de avaliar em comparação com outros tipos de solos, como os de origem sedimentar por exemplo, principalmente porque é difícil quantificar de forma fidedigna a suas propriedades de engenharia. As três características dominantes destes materiais são:

- para propósitos de análise e projeto, é necessário considerar o perfil de intemperização completo, desde o material completamente intemperizado 'solo' (na superfície), até a rocha sã a alguma profundidade;

- em qualquer profundidade, os solos residuais são geralmente extremamente heterogêneos, este fato os faz de difícil amostragem e teste; e

- os solos residuais são invariavelmente não saturados e de permeabilidade relativamente alta, o que significa que suas propriedades de engenharia são facilmente afetadas pela precipitação.

\subsubsection{PERFIL DE INTEMPERIZAÇÃO}

O perfil de intemperização é a seqüência de camadas de materiais com propriedades físicas diferentes desenvolvidas in situ, apoiadas numa camada resistente não intemperizada. O perfil de intemperização pode ser formado pela intemperização mecânica, que é a desintegração da estrutura original da massa rochosa, ou pela intemperização química, que é a descomposição dos materiais originais da massa rochosa. Ambas, a intemperização química e intemperização mecânica, podem se apresentar juntas, acelerando-se a intemperização da rocha. No processo mecânico incluí-se a desintegração do solo ou rocha pelo alivio de tensões por descarga, causadas pela erosão do solo.

O perfil de intemperização pode variar consideravelmente de lugar a lugar devido as variações locais do tipo de rocha, estrutura rochosa, topografia, nível de erosão e condições da água subterrânea, e também pelas variações do clima, particularmente as precipitações. 
No presente trabalho apresenta-se o perfil de intemperização proposto por Deere \& Patton (1971), cujos critérios de classificação foram:

- os termos utilizados devem ser simples e fáceis de lembrar;

- a divisão do perfil não deve diferir muito dos perfis apresentados por outros autores;

- símbolos tradicionais e convencionais devem ser utilizados sempre que seja possível; e

- os termos ambíguos devem ser evitados.

Segundo Deere \& Patton (1971), quase todos os perfis de rocha intemperizada formadas sobre rocha ígnea intrusiva e sobre rocha metamórfica podem apresentar três subdivisões (1) solo residual, (2) rocha intemperizada, e (3) camada rochosa não intemperizada. Nos perfis estas subdivisões são representadas em números romanos I, II e III. Esta seqüência é mostrada na Figura 2.21, para rochas ígneas e metamórficas.

O solo residual é subdividido em três zonas, IA, IB e IC, que correspondem aos horizontes A, B e C respectivamente da Pedologia. O horizonte $\mathrm{C}$ é considerado pelos pedólogos como o material de origem dos solos dos horizontes A e B.

\section{Zona IA}

Denomina-se como zona eluvionar, onde a água infiltrada leva consigo material em suspensão. A textura arenosa freqüentemente se desenvolve no horizonte A. A porção superior do horizonte A é normalmente orgânica.

\section{Zona IB}

É a zona de deposição do material sólido transportado do horizonte A. Estes solos são comumente de cor escura, ricos em minerais argilosos, e lixiviados de seus componentes solúveis originais. Algumas vezes este horizonte é rico em sílica, alumínio ou ferro, e as vezes cimentado. Devido a esta adição de materiais e as variações climáticas, este horizonte varia consideravelmente em suas propriedades físicas. 

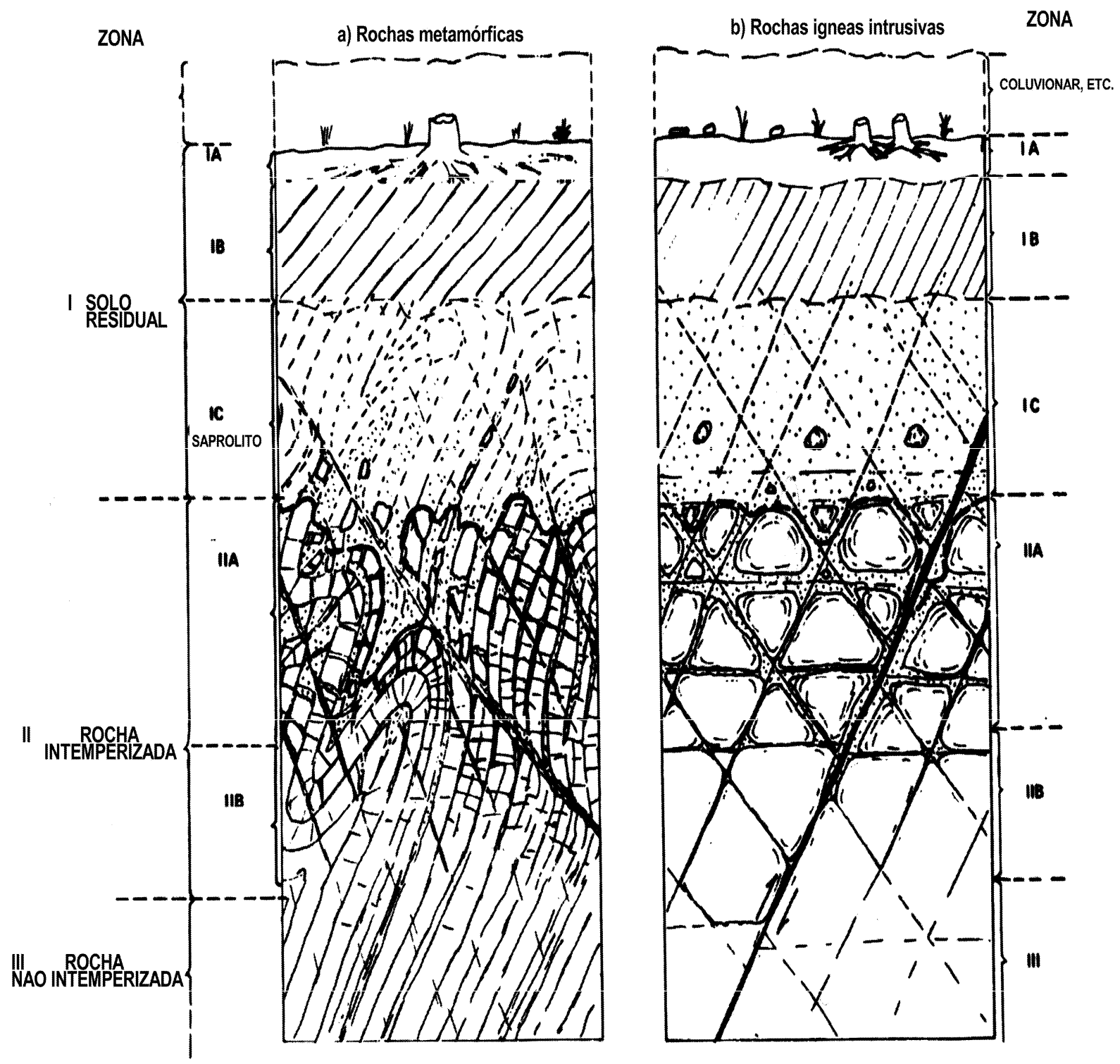

FIGURA 2.21- Perfil de intemperização típica para rocha ígnea intrusiva ou metamórfica. Deere \& Patton, 1971.

\section{Zona IC}

Este horizonte é reconhecido pelas evidencias da estrutura da rocha original, no entanto, este horizonte é mais solo que rocha. A estrutura rochosa presente conserva a posição relativa original da orientação das juntas e falhas. Os feldspatos são convertidos em caolinita ou outro mineral argiloso, a mica é parcial ou completamente degradada e alterada, e muitos outros minerais presentes da rocha de origem com exceção do quartzo são alterados. A areia siltosa e silte arenoso predominam nesta zona. O termo comumente aplicado a este horizonte é "saprolítico". 


\section{Zona IIA}

Zona de transição do saprolito à rocha. Este horizonte é comumente muito permeável, filtrando-se rapidamente água das sondagens que atingem este horizonte.

\section{Zona IIB}

A rocha presente sofre alterações ao longo das juntas. Também aqui, começa a alteração do feldspato e mica, e em alguns casos em alto grau. Conforme a alteração avança a rocha é degradada de seu estado original a outro de resistência mais baixa, com incremento da permeabilidade. Esta permeabilidade se produz como resultado de (1) variações de volume ao tomar a nova forma mineral, (2) solução de alguns dos constituintes mais solúveis, e (3) incremento de juntas, e abertura das juntas preexistentes devido ao alivio de tensões causadas pela erosão.

\section{Zona III}

Ou camada rochosa, não intemperizada e sem alterações da mica ou feldspato. No entanto poderia ter um alto porcentagem de juntas.

\subsubsection{ESTABILIDADE DE TALUDES EM SOLO RESIDUAL}

O grau de instabilidade de um talude será tanto maior, quanto menor for a relação entre a resistência ao cisalhamento do solo e as tensões cisalhantes ao longo de uma superfície potencial em que possa haver movimentos de massa. Portanto, os agentes instabilizadores são os que podem provocar decréscimo na resistência e/ou acréscimo das tensões de cisalhamento.

Os principais fatores que contribuem para o acréscimo das tensões cisalhantes são (Varnes, 1978):

- desconfinamento lateral decorrente de erosões, queda de blocos, trabalho do homem, etc.;

- sobrecarga, imposta pela construção de aterro, acúmulo de água, estocagem de materiais ou de resíduos, construções, etc.;

- pressões de percolação de água dentro do maciço;

- pressões laterais, causadas pelo empuxo de água ao preencher fendas no maciço, inchamento de solos expansivos em contato com água, mobilização de tensões residuais; e

- tensões transitórias, provocadas por sismos, vibrações devidas a explosivos, maquinas, etc. 
Entre os principais fatores que causam decréscimo na resistência do solo destacam-se:

- redução das tensões de sucção matricial, decorrente do aumento do grau de saturação do solo;

- descontinuidades herdadas da rocha matriz, tais como, falhas, juntas, fraturas, etc;

- modificação da estrutura de solos sensíveis, provocada por solicitações dinâmicas;

- liquefação de areias finas saturadas, provocada por vibrações; e

- perda de coesão, por hidratação de minerais argilosos expansivos.

De todos os fatores acima citados, a água de chuva é, sem duvida o mais importante agente instabilizador de taludes em solos de clima tropical. O maior testemunho do efeito danoso da água é a constatação dos deslizamentos por ocasião dos períodos chuvosos, geralmente nos primeiros meses do ano. (Gaioto \& Queiroz, 1993).

Segundo Blight, G. (1997), os taludes naturais em solo residual parecem estar geralmente estáveis, no entanto essa estabilidade pode ser alterada, tanto por pequenos eventos naturais não usuais, quanto pela intervenção humana. Os eventos que produzem essa instabilidade são: (1) Precipitação intensa e prolongada, (2) Eventos sísmicos e, (3) Interferência humana.

\subsubsection{PRECIPITAÇÃO INTENSA E PROLONGADA}

Muitos taludes naturais de solo residual existem em condição não saturada e sua margem de segurança contra deslizamento depende da sucção que existe na água intersticial, que incrementa a resistência do solo. Blight et al. (1970) encontraram que num talude natural de siltito intemperizado, a sucção matricial variava, depois de ligeiras chuvas, de zero na superfície até $1000 \mathrm{kPa}$, a $1 \mathrm{~m}$ de profundidade. De forma que a infiltração, reduz a sucção matricial, podendo até instabilizar o talude. Brand (1982) e Lim et al (1996), observaram que a sucção matricial na superfície de taludes de solo residual em Hong Kong e Singapura, tendia a zero durante prolongadas chuvas.

Lumb (1975) sugere que a taxa limite de infiltração da chuva dentro de um solo homogêneo, na ausência de uma superfície de água, é numericamente igual à permeabilidade saturada dele. Na Figura 2.22 pode-se observar que o avanço da água dentro do solo possui uma espessura de:

$$
\mathrm{h}=\frac{\mathrm{K}_{\mathrm{s}} \mathrm{t}}{\mathrm{n}\left(\mathrm{S}_{\mathrm{f}}-\mathrm{S}_{\mathrm{o}}\right)}
$$


Onde:

$\mathrm{K}_{\mathrm{s}}$ : permeabilidade saturada;

$\mathrm{S}_{\mathrm{f}}, \mathrm{S}_{\mathrm{o}}$ : graus de saturação final e inicial; e

$\mathrm{n}$ : porosidade.

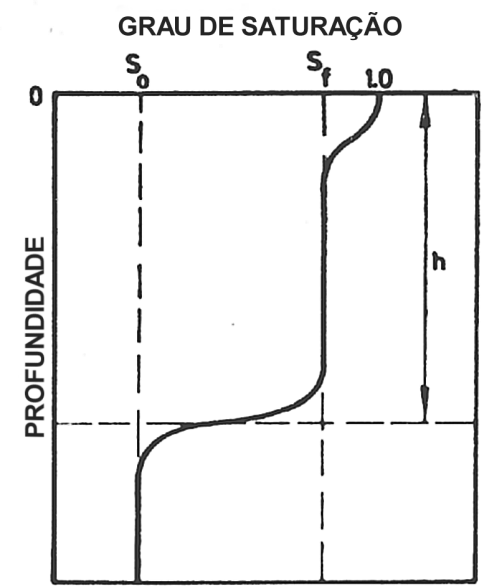

FIGURA 2.22- Avanço da frente de umedecimento causada pela infiltração da água (Lumb, 1975).

Usando valores típicos para permeabilidade do solo e intensidade de chuva, Lumb (1975) mostrou que em poucas horas o nível da água poderia atingir uma profundidade crítica no talude, provocando-se sua instabilidade.

Boonsinsuk \& Yong (1982) investigando a estabilidade de taludes em solos formados por granito residual descomposto de Hong Kong, mostraram como as variações da duração de precipitação, de uma intensidade pelo menos igual à permeabilidade da superfície saturada, reduz o fator de segurança do talude. A Figura 2.23, mostra alguns dos resultados das análises feitas como a relação entre o fator de segurança versus profundidade de penetração da chuva. No exemplo, a ruptura ocorre depois de $20 \mathrm{~h}$ no primeiro caso e depois de $36 \mathrm{~h}$ no outro.

No exemplo foram utilizados dois modos de ruptura. No primeiro assumiu-se que a coesão (C's) era nula na zona saturada sobre a frente úmida e o fator de segurança foi determinado em função do avanço desta frente (h). O resultado da figura 2.23 baseou-se nos ábacos de Hoek e Bray (1977) onde a coesão média utilizada foi dada por $\{(\mathrm{H}-\mathrm{h}) / \mathrm{H}\} \mathrm{C}$ 's. No segundo modo considerou-se que a sucção do solo u* ou a coesão aparente (C's) era nula na zona saturada sobre a frente úmida, e a coesão real $\left(C^{\prime} t\right)$ não era afetada pela variação da sucção. $\mathrm{O}$ fator de segurança determinou-se utilizando a coesão média de C't $+\{(\mathrm{H}-\mathrm{h}) / \mathrm{H}\} \mathrm{C}^{\prime}$ s. 
Na determinação do tempo de precipitação do mesmo exemplo, utilizou-se a equação 2.38 da forma $\mathrm{v}=\mathrm{K}_{\mathrm{s}} / \mathrm{n}\left(\mathrm{S}_{\mathrm{f}}-\mathrm{S}_{0}\right)$, onde ' $\mathrm{v}$ ' é a velocidade de infiltração, e os parâmetros adotados foram $\mathrm{K}_{\mathrm{s}}=8 \times 10^{-6} \mathrm{~m} / \mathrm{s}, \mathrm{S}_{\mathrm{f}}=1, \mathrm{~S}_{0}=0,75$ e $\mathrm{n}=0,4$.
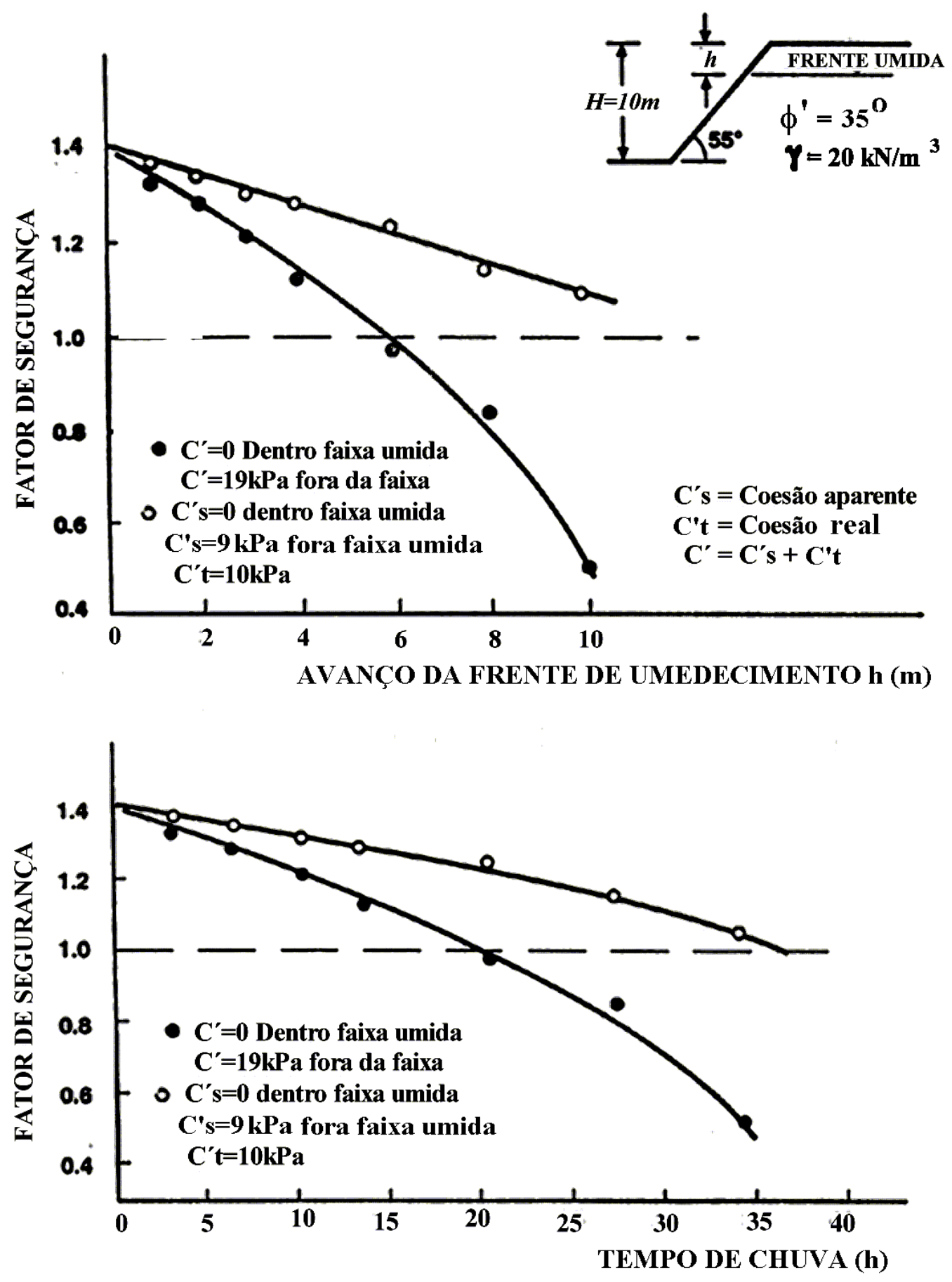

FIGURA 2.23- Efeito da infiltração da água de chuva (acima) e duração da precipitação (abaixo) versus o fator de segurança (Boonsinsuk \& Yong, 1982). 
No Brasil, uma das maiores séries de chuvas associadas a deslizamentos ocorreram na Serra das Araras em 1967 (Da Costa Nunez, 1969), onde a intensidade da chuva chegou a $70 \mathrm{~mm} / \mathrm{h}$ numa área $180 \mathrm{~km}^{2}$, acarretando vários escorregamentos que provocaram uma serie de devastações e perdas humanas.

\subsubsection{INTERFERÊNCIA HUMANA}

Muitos tipos de interferência humana podem afetar a estabilidade de taludes, sendo os mais comuns: (Blight, 1997)

\section{Remoção ou erosão do suporte no pé do talude.}

A introdução de uma escavação no pé de um talude natural longo poderia precipitar um deslizamento. O deslizamento ocorrido em Bethlehem - Sul da África (Blight et al, 1970), é um exemplo típico de ruptura por remoção (ver Figura 2.24), onde foi realizado uma escavação para a construção de uma estrada. Em investigações feitas no talude o deslizamento envolveu um bloco intemperizado que escorregou sobre seu contato com um estrato de siltito.

\section{Mudanças no regime da água do solo.}

Se o regime da água é alterado drasticamente por alguma irrigação, ou é removida a vegetação, ou se produz uma inundação, a instabilidade pode ser iniciada (Reichards, 1985). O mais espetacular e trágico exemplo de instabilidade por alteração do nível da água em um talude natural de solo residual é a ruptura no vale de Vaiont descrita por Muller (1964) \& Mencl (1966). Durante o enchimento da água de uma nova barragem, o talude de $600 \mathrm{~m}$ de altura, em material intemperizado residual, começou a ter creeping (rastejo) num lado do reservatório e após três anos a massa deslizada, repentinamente, precipitou-se dentro do reservatório produzindo grandes estragos. 

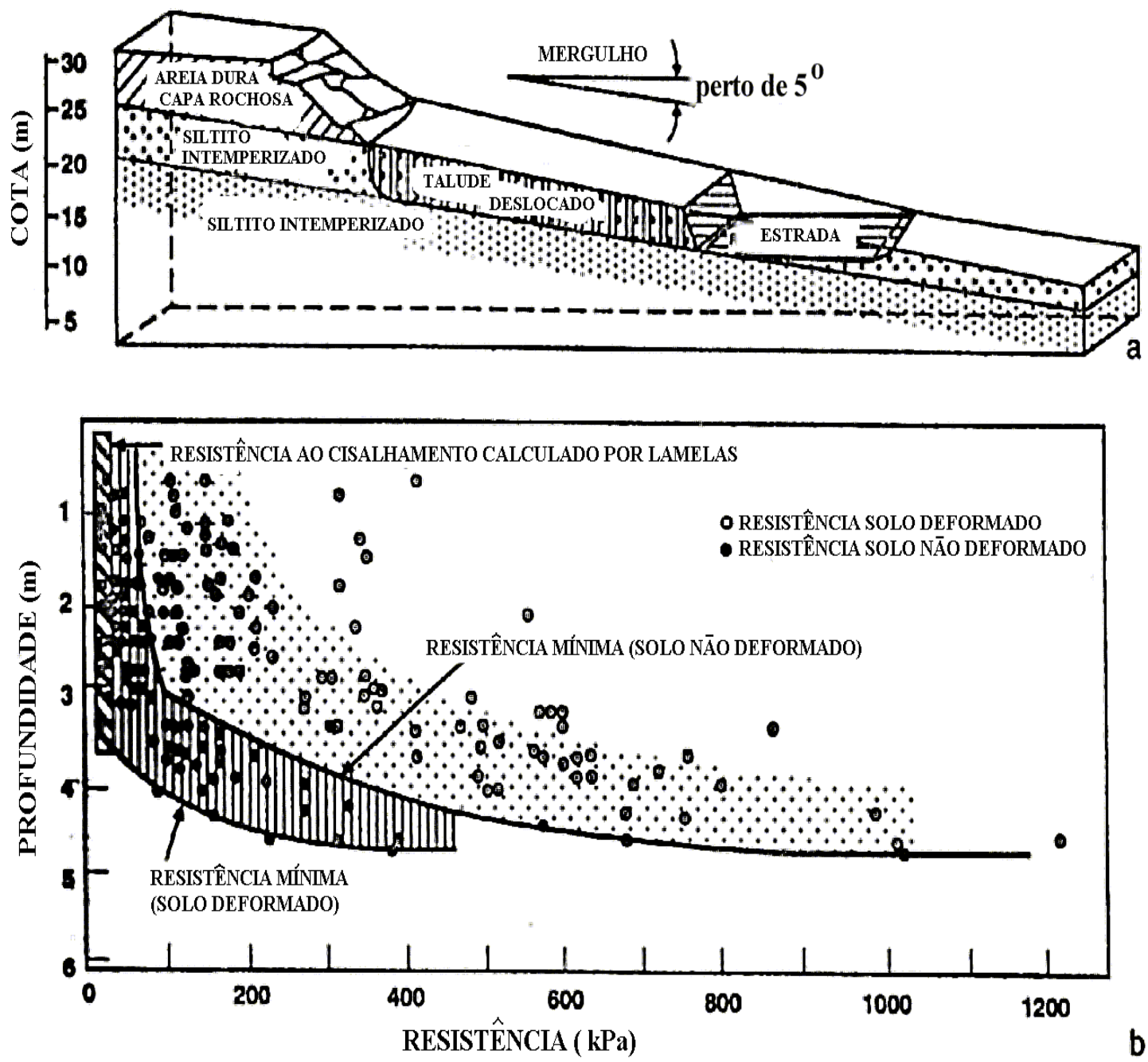

FIGURA 2.24- a) Seção do bloco mostrando a geologia de Bethlehem, b) medidas de ensaios de Vane em siltito intemperizado (Blight et al, 1970).

\section{Efeito do desmatamento.}

Segundo Blight (1987) ao remover vegetação com raízes profundas as tensões capilares se reduziriam e a superfície freática no talude provavelmente aumentaria.

As raízes mecanicamente reforçam o solo. A estabilidade do talude poderia ser reduzida se o sistema geral de raízes for reduzido depois de remover a vegetação superficial. A importância relativa dos fatores mencionados dependem das condições climáticas. Em clima úmido remover as raízes acelera a instabilidade. Sob condições semi áridas, no entanto, a redução dos níveis de evapotranspiração causadas pelo desmatamento poderia superar todos os outros efeitos. 


\subsubsection{RELAÇÃO ENTRE PRECIPITAÇÃO E ESCORREGAMENTO}

A precipitação é a mais importante causa de escorregamentos em taludes de solos residuais, e alguns estudos de importância foram feitos para relacionar a ruptura de taludes com a precipitação. Correlações foram formuladas no Brasil por Barata (1969), Guidicini \& Iwasa (1977), nos Estados Unidos por Campbell (1975), Nilsen et al (1976), e em outros países por Eyles (1979) e Lumb (1975, 1979), dentre outros.

No entanto, é raro ter disponível informações detalhadas, sobre a distribuição geográfica e intensidades a curto prazo da precipitação. As medidas de precipitação comumente são feitas por dia e em estações diferentes. É também raro se determinar o instante do escorregamento.

A relação entre precipitação e escorregamento foi estabelecida para Hong Kong por Lumb (1975, 1979), que classificou os eventos de escorregamento em quatro categorias, definidas a seguir:

- 'evento desastroso' - com mais de 50 rupturas individuais registradas em um dia, no âmbito do território de Hong Kong;

- 'evento severo' - entre 10 e 49 rupturas registradas em um dia;

- 'evento menor' - dano localizado, com menos de 10 rupturas em um dia; e

- 'evento isolado' - uma única ruptura.

Um estudo detalhado de dados de precipitação e de escorregamento em solo residual de Hong Kong entre 1953 a 1983 permitiram chegar as seguintes conclusões (Brand et al, 1984):

- a grande maioria dos escorregamentos são induzidos por precipitações localizadas de curta duração e de alta intensidade, e estes escorregamentos acontecem aproximadamente ao mesmo tempo que a precipitação horária de pico;

- antes da precipitação, não se tem um fator de importância na ocorrência de escorregamentos, exceto em casos de escorregamentos menores que ocorrem com precipitações de baixa intensidade e curta duração; e

- uma intensidade de precipitação de $70 \mathrm{~mm} / \mathrm{h}$, com um tempo de precipitação de 2 horas, parece ser um valor crítico que produz a ruptura. O número de escorregamentos e a severidade das conseqüências aumentam dramaticamente com o incremento da intensidade horária sobre este nível. 


\subsubsection{ANÁLISE DE ESTABILIDADE DE TALUDES}

Devido à natureza do perfil intemperizado e solo coluvionar sobrejacente, o estudo da estabilidade de taludes em solos residuais necessariamente deve combinar a análise tradicional de mecânica dos solos e mecânica das rochas, com o conhecimento da engenharia geológica de cada situação. Infelizmente, as vezes, em engenharia geotécnica não se conta com os parâmetros suficientes para o projeto. Além disso, tem-se situações onde a complexidade da geologia local dificulta a análise.

É quase uma certeza que a maioria dos taludes de corte que existem em solo residual não foram projetados no sentido estrito da engenharia, como aconteceu em muitos taludes de corte antigos de Hong Kong (Brand, 1985), onde verificou-se que os fatores de segurança teóricos foram menores que 1 , no entanto, muitos taludes mantiveram-se estáveis durante muitos anos sob condições severas de precipitação.

Os métodos de análise de estabilidade de taludes segundo Brand (1985) são:

- métodos tradicionais. Nestes métodos é usual determinar o fator de segurança fazendo uso da análise de equilíbrio limite;

- métodos de projeto semi - empíricos. Estes métodos apoiam-se em conhecimentos amplos do desempenho de taludes existentes; e

- avaliação do terreno. Estes métodos são realizados em grande parte com base em fotografias aéreas, para classificar a superfície, principalmente, desde o ponto de vista da estabilidade, o que pode conduzir ao zoneamento da mesma em termos de risco ou perigo.

Estes três métodos têm sido aplicados com sucesso em solos residuais. O método tradicional tem a vantagem de quantificar o grau de segurança, não sendo possível tal quantificação com os outros dois métodos. O método semi empírico e o método por avaliação do terreno são baseados na suposição explícita que as características de estabilidade de uma determinada região, pode ser avaliada com base em observações do desempenho de regiões com características semelhantes.

\subsubsection{ANÁLISE DE TALUDES POR MÉTODOS TRADICIONAIS}

A estabilidade de talude é comumente determinada em função do fator de segurança que é definido como a razão entre a resistência média ao cisalhamento, e a tensão média ao 
cisalhamento, ao longo da superfície potencial de ruptura. Para utilizar os métodos tradicionais, fatores como a geometria, a resistência do solo e a distribuição de pressão neutra, devem ser conhecidos.

O êxito da aplicação do método tradicional a algum problema de estabilidade de taludes depende de definir a superfície de ruptura potencial crítica convenientemente (modo de ruptura).

A seleção do modo de ruptura possível deve-se basear no conhecimento da geologia in situ e do perfil do solo intemperizado. A ruptura de taludes residuais deve ocorrer freqüentemente ao longo das superfícies menos resistentes, antigas juntas e falhas, ou pelos limites dos perfis intemperizados. As superfícies de ruptura circular ou em arco geralmente não se apresentam, sendo a superfície de ruptura não circular e superficial a mais comum (Lumb 1975), no entanto, normalmente são utilizadas superfícies circulares para facilitar a solução do problema. Os métodos particulares bem conhecidos nesta categoria são os métodos de Janbu (1954,1973), Morgenstern \& Price, (1965), Spencer, (1967), Madej (1971) e Sarma (1973). Os três primeiros são os mais usuais. Os métodos de Morgenstern \& Price e Sarma são mais rigorosos do ponto de vista mecânico, que o método de Janbu.

Outros métodos além dos mencionados são o método de Fellenius (1936), Bishop (1955), Kenney (1956), Chugaev (1964), Nonveiller (1965) e Bell (1968). Estes métodos e os anteriormente mencionados são baseados no principio de equilíbrio limite e no critério de ruptura de Mohr Coulumb e, principalmente diferem nas simplificações que permitem tornar o problema determinado.

Todos os métodos de equilíbrio limite da análise de estabilidade de taludes empregam suposições para reduzir o número de incógnitas que será igual ao número de equações de equilíbrio. No entanto, nem todos os métodos de equilíbrio limite satisfazem as mesmas condições de equilíbrio. Alguns métodos, como o método generalizado de Janbu e o método de Morgenstern \& Price, satisfazem todas as condições de equilíbrio. Estes provêm duas equações de equilíbrio de forças e uma equação de equilíbrio de momentos para cada fatia, e $3 \mathrm{~N}$ equações no total, onde $\mathrm{N}$ é o número de fatias. Outros métodos, como o método simplificado de Bishop e o método de Fellenius não satisfazem todas as condições de equilíbrio. O método de Bishop não satisfaz o equilíbrio de forças horizontais de cada fatia e o método de Fellenius não satisfaz o equilíbrio de forças em cada fatia.

Comparações entre os métodos de cálculo do Fator de Segurança foram feitos por Whitman \& Moore (1963), Wright et al (1973), Fredlund \& Krahn (1977), Morgenstern e Sangrey (1978), Duncan (1980), Duncan \& Wright (1980), Fredlund at al (1981), Ching \& Fredlund (1983) e Fredlund (1984). 
Segundo Wright et al. (1973) embora, as teorias de equilíbrio limite na análise de estabilidade de taludes tenham sido amplamente utilizadas e com êxito, estes métodos são criticados por três razoes:

- a tensão normal na superfície cisalhada é determinada sem consideração das características tensão - deformação do solo;

- quase todos os métodos assumem que o FS é o mesmo para todas as fatias, coisa que só acontece na ruptura onde $\mathrm{FS}=1$; e

- alguns dos métodos de equilíbrio limite, como o método ordinário de fatias ou método de Fellenius, o método simplificado de Bishop, e os métodos de cunha baseados no equilíbrio de forças, não satisfazem todas as condições de equilíbrio.

Por outro lado os estudos comparativos dos métodos de equilíbrio limite, feitos por Whitman \& Baley (1967) e Wright (1969), levaram as seguintes conclusões:

- os valores do FS calculados pelos métodos Generalizado de Janbu e Morgenstern \& Price são muito próximos;

- os valores do FS calculados pelo método simplificado de Bishop são geralmente comparáveis com aqueles calculados pelos métodos que satisfazem todas as condições de equilíbrio limite. As diferenças encontradas variam entre 0 e $6 \%$ para uma ampla variedade de condições de inclinação de talude, resistência ao cisalhamento e pressão neutra; e

- os valores do FS calculados pelo método de Fellenius são geralmente menores que aqueles calculados pelos métodos que satisfazem todas as condições de equilíbrio, e são também menores que aqueles calculados pelo método simplificado de Bishop. Em condições extremas o valor do FS calculado pelo método de Fellenius pode ser a metade do valor calculado pelos métodos que satisfazem todas as condições de equilíbrio.

\subsubsection{MÉTODOS DE PROJETO SEMI EMPÍRICO}

Devido às dificuldades inerentes de aplicação do método tradicional na análise de estabilidade de taludes em solos residuais, algumas tentativas baseadas na experiência, foram feitas para formular 'regras' de projeto. O uso deste método tem sido limitado, e foram reportados só alguns exemplos úteis na literatura. Um grupo específico de regras só pode ser aplicada a uma formação geológica específica numa locação geográfica determinada, sendo elas produto da topografia, geologia e clima daquela locação. As regras utilizadas numa 
locação, porém, podem prover, freqüentemente, orientação, ou pelo menos um ponto de partida, para o estabelecimento de regras para uma formação geológica semelhante em outra locação.

Tem-se muitas publicações registradas do desenvolvimento de regras de projeto semi empíricas estabelecidas com base na avaliação da estabilidade e instabilidade de taludes. Os enfoques utilizados caem dentre dois grupos. O primeiro tende a ser extremamente simples e está baseado só em duas variáveis - altura do talude e ângulo do talude (Lane (1961), Gates (1972), Taylor et al (1977), Shuk (1968), entre outros); a outra opera com base na análise estatística de um número grande de parâmetros geológicos e geomorfométricos (Carson (1969), Young (1972), Schumm \& Mosely (1973), Carrara (1983), entre outros). Os métodos do primeiro tipo foram usados com sucesso em várias locações e os métodos do segundo tipo geralmente são extremamente complicados na sua aplicação e nem sempre são de fácil implementação para uso geral em projetos na engenharia.

Talvez o primeiro método de projeto semi empírico simples, foi o publicado por Lane (1961) que correlacionou, durante 1953-56, alturas de taludes e ângulos de taludes para uma argila xistosa em Montana, Norte de Dakota. Os exemplos incluíram taludes naturais e taludes de corte, os resultados são apresentados na Figura 2.26.

O projeto envolveu a análise de $16 \mathrm{Km}$ de taludes, muitos deles com mais de $60 \mathrm{~m}$ de altura e só um com $90 \mathrm{~m}$.

Foram obtidos perfis de solo e seções geológicas para vinte e cinco taludes incluindose três escorregamentos, dos quais dois eram susceptíveis de uma análise detalhada. Valores diferentes de ângulo de atrito e de coesão eram então experimentados com o propósito de ajustar uma curva em função dos dados básicos do talude (ângulo de inclinação e altura). A utilização dos ábacos de Taylor (1937) permitiram determinar facilmente as curvas de igual fator de segurança, para as diferentes combinações assumidas de ângulo de atrito e coesão.

\subsubsection{MÉTODOS POR AVALIAÇÃO DO TERRENO}

‘Classificação do terreno’ é o termo geralmente aplicado à categorização do solo com base em certo número de atributos, usando a interpretação de fotografias aéreas. Esta técnica é aplicada em quase todos os terrenos do meio estudado, porque proporciona um mecanismo para uma rápida investigação de uma superfície de ruptura, e classifica o terreno dentro de 'unidades' homogêneas. Para aplicações geotécnicas é necessário categorizar os atributos físicos relevantes e classificar o terreno apropriadamente. A avaliação do terreno é desenvolvida com base na sua classificação, selecionando os atributos em terreno estável ou 
instável, ou terreno bom ou ruim (Brand, 1985). Um dos pioneiros na avaliação do terreno para engenharia foi Grant $(1965,1970)$, que apresentou uma série de relatórios de avaliação do terreno em diversas zonas de Austrália nos períodos de 1965-1980.

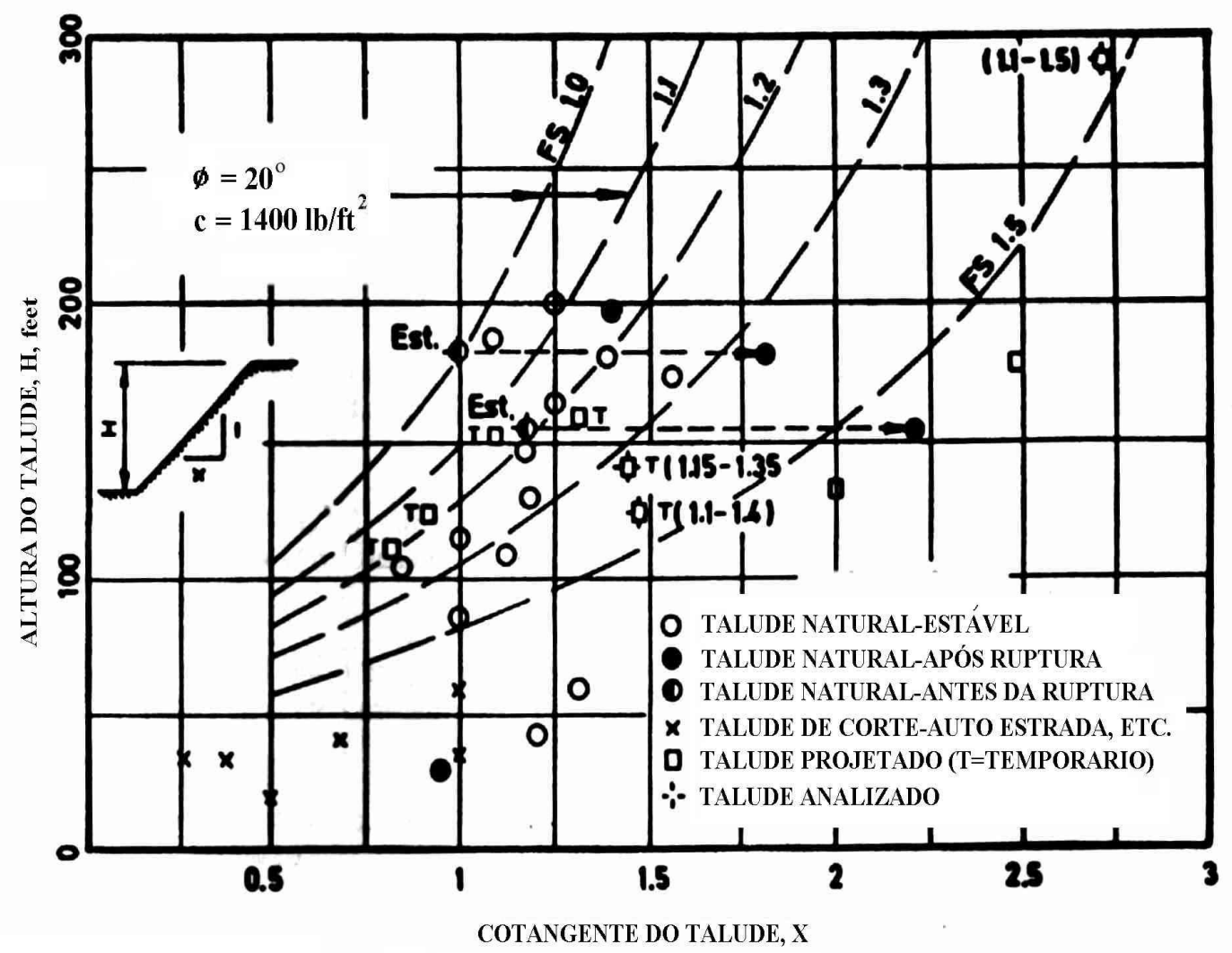

FIGURA 2.26- Correlação entre a altura do talude e angulo para xisto argiloso, Lane (1961).

\subsubsection{INSTRUMENTAÇÃO EM TALUDES}

O avanço da mecânica de solos não saturados permitiu um melhor entendimento do rol da sucção na estabilidade de taludes em solos residuais. No entanto, a sucção nos taludes varia com as condições climáticas. Uma visão deste fenômeno pode ser alcançada monitorando as condições do talude durante um período de tempo prolongado, através de uma instrumentação planejada.

Os perfis de sucção num talude dependem das propriedades do solo, posição do lençol freático, gradiente de temperatura e do índice de precipitação pluviométrica. A determinação das propriedades do solo é parte da caracterização in situ e deveria incluir a determinação da permeabilidade e características da água do solo. Os outros fatores variam com as condições climáticas: O nível do lençol freático está sujeito às flutuações sazonais, o gradiente de 
temperatura muda com as condições de luz solar diária e a precipitação varia dependendo da época do ano. Algumas considerações (observações, limitações, alternativas, etc.), terão que ser dadas aos tipos de instrumentos, profundidades das medidas, número de instrumentos, sistema de aquisição de dados e proteção do sistema de instrumentação, para o estudo dos efeitos climáticos em uma condição de talude de solo residual.

Com o propósito de estudar o efeito da evapotranspiração e a infiltração da água de chuva num talude de solo residual em Singapura, Leong et al (1998) fizeram a instrumentação de um talude em campo. Para medir as sucções matriciais inferiores a $85 \mathrm{kPa}$ utilizaram-se Tensiômetros, e para medir sucções matriciais maiores a este valor utilizaram-se sensores de condutividade térmica. A precipitação foi medida utilizando um pluviômetro; a variação do nível de água utilizando piezômetros de Casagrande, e a leitura da temperatura foi feita com transdutores de temperatura. Na Figura 2.27, pode-se ver detalhes da localização dos instrumentos utilizados.

Utilizou-se, também, um sistema de aquisição de dados para monitorar os instrumentos instalados. Ambos, os instrumentos e o sistema de aquisição de dados foram protegidos de possíveis danos. Para recarregar as baterias utilizou-se um painel solar.

Concluiu-se da instrumentação, que levar as leituras dos instrumentos a um local remoto sempre é um problema. O problema principal é a fonte de energia para o sistema de aquisição de dados. O problema fica mais agudo com o incremento do número de instrumentos. Outros problemas incluem a proteção dos instrumentos e do sistema de aquisição de dados de possíveis danos.

Concluiu-se, também, que da experiência obtida com o programa de instrumentação é possível conduzir outros estudos similares, e que os dados obtidos do monitoramento permitirão melhorar o entendimento do efeito do clima no perfil de sucção matricial em taludes. 
PLANTA

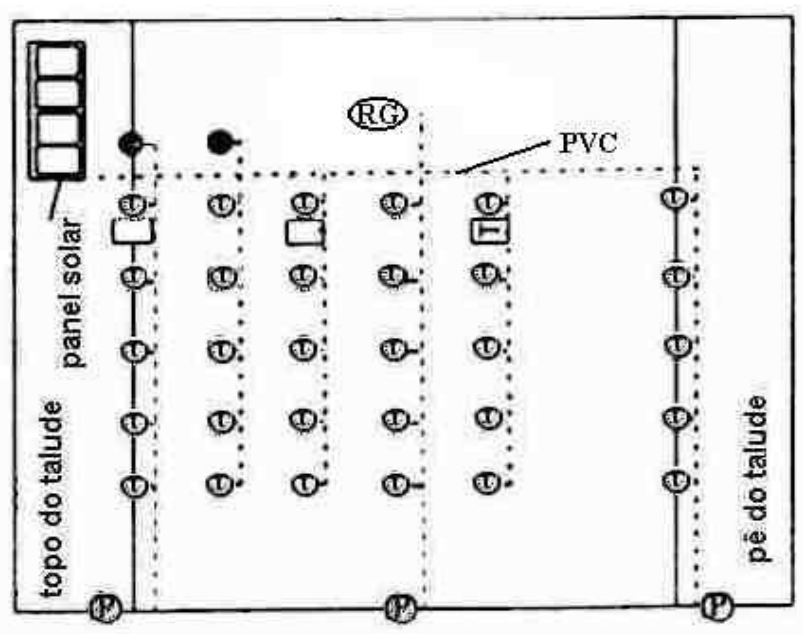

CORTE

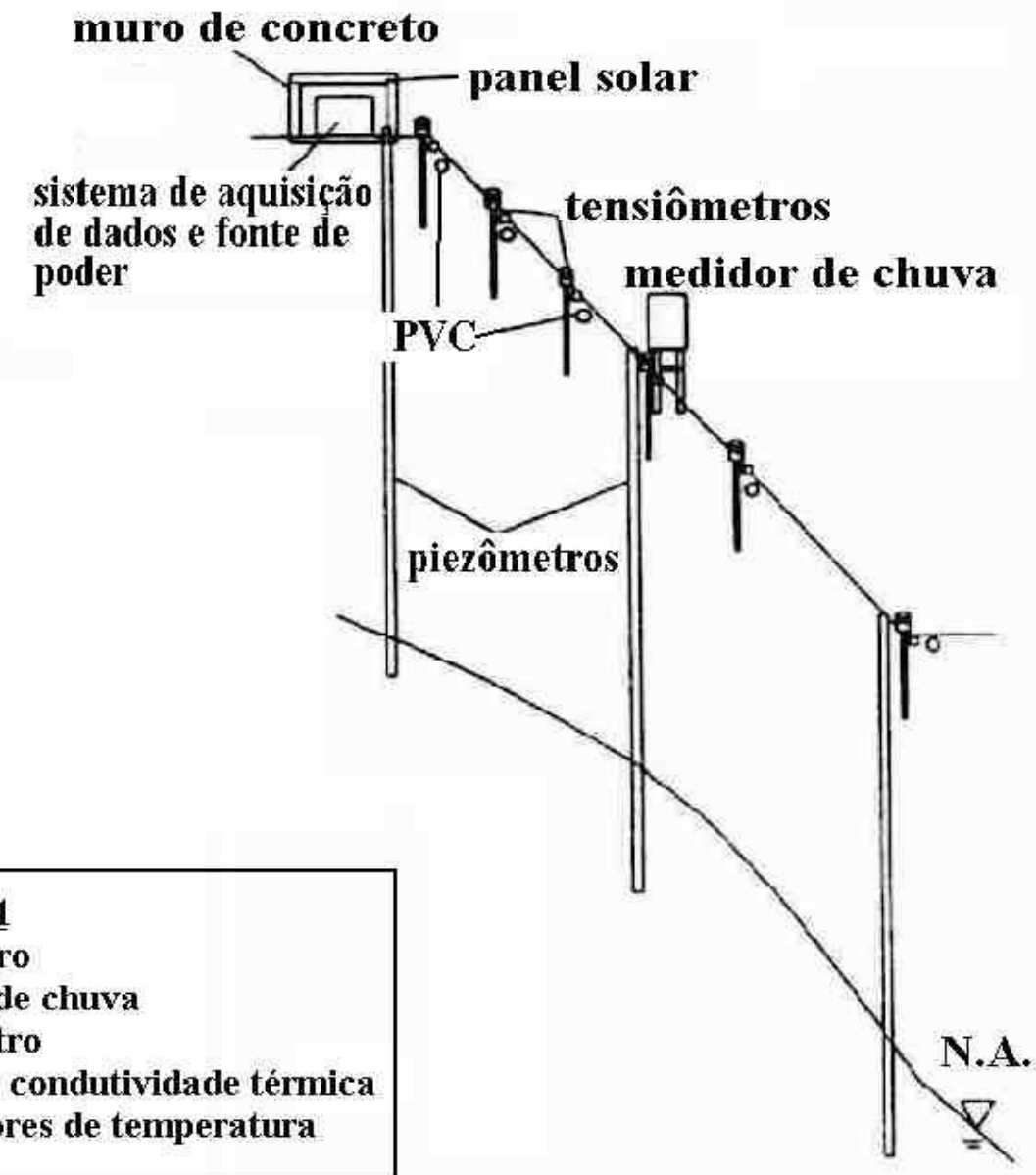

FIGURA 2.27 - Instrumentação de um talude em solo residual Singapura, Leong et al (1998). 


\subsection{RETRO-ANÁLISE}

É uma técnica de controle de parâmetros de um sistema, analisando-se seu comportamento. Em retro-análise, de forma geral, os sistemas de carga como: carga externa e as propriedades mecânicas do solo ou da rocha como: Módulo de elasticidade, coeficiente de Poisson, coesão, ângulo de atrito, etc., são determinados em função dos deslocamentos, tensões e medidas de pressão.

Este procedimento é oposto do método de análise ordinário, onde as condições de carga e propriedades mecânicas são parte dos dados para a determinação dos deslocamentos, tensões, deformações, ou Fator de Segurança. A relação entre os dois métodos é apresentada na Figura 2.28.

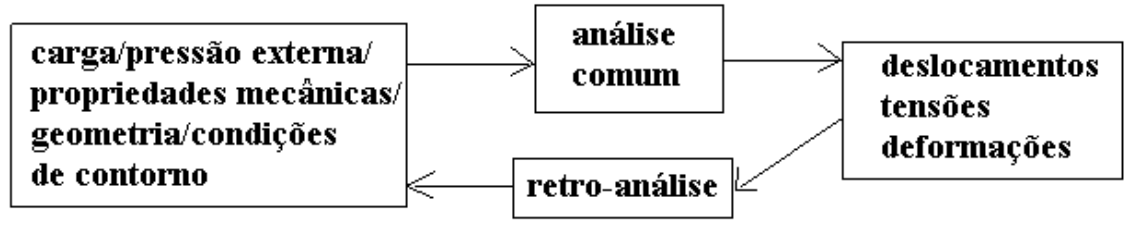

FIGURA 2.28- Relação entre análise comum e retro-análise (Sakurai, 1993).

A diferença entre a análise comum e a retro-análise é mostrada na Figura 2.29. Podese ver na análise comum a singularidade do resultado garantida, ainda quando o comportamento real do solo seja diferente do modelo considerado. No entanto, na retroanálise a unicidade não é garantida porque a modelagem é levada a cabo depois de obter os dados. Portanto para obter um resultado único na retro-análise, deve-se ter um grande cuidado na modelagem. O modelo deve ser o mais preciso possível para representar o comportamento real do solo.

(a) Análise comum

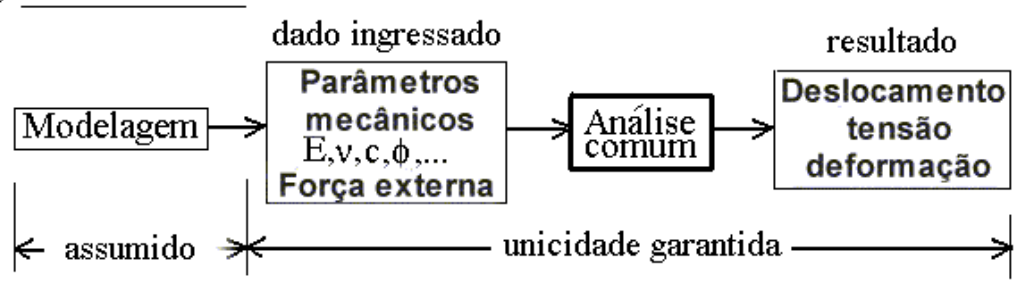

(b) retroanálise

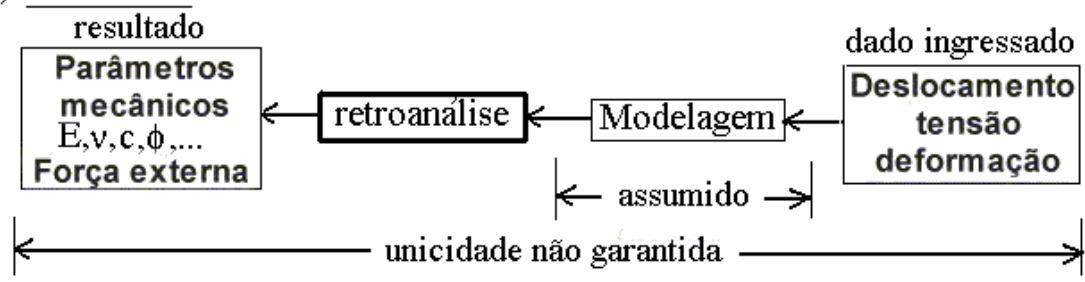

FIGURA 2.29- comparação entre a) Analise comum e b) Retro-análise (Sakurai, 1993). 
Segundo Guidicini \& Nieble (1976), a retro-análise é um método apropriado, bastante rápido e de baixo custo, de avaliação da estabilidade de massas terrosas e rochosas e consiste na observação e na análise de casos de colapso já ocorridos. Dada uma determinada área a ser estudada (área montanhosa, mineração a céu aberto, etc.), é plausível supor que nela já tenham ocorrido fenômenos de instabilização. O estudo desses casos permitirá obter dados de resistência ao cisalhamento, que poderão ser usados em projetos na mesma área.

Quando um talude sofre colapso, está-se admitindo que o fator de segurança, no momento da ruptura, tenha caído ao valor da unidade. Trata-se então de reconstituir as condições do talude pré-ruptura, seja na geometria, seja nas principais forças atuantes. A partir desses dados, que podem ser levantados com razoável aproximação, avaliam-se as características de resistência.

A geometria do talude antes da ruptura pode ser reconstituída a partir das curvas de nível que permaneceram intatas ou, no caso de minerações, a partir dos registros topográficos de avanço das escavações. Através de levantamento topográfico, obter-se-á o perfil da superfície de movimentação em uma ou mais seções representativas. Com isso se avalia o volume da massa movimentada.

A observação da superfície de movimentação e da própria massa escorregada pode indicar a existência, ou não, de fraturas de tração que tenham desempenhado papel relevante no mecanismo de ruptura.

A densidade do material é facilmente obtida assim como o peso da massa movimentada. As irregularidades ao longo da superfície de movimentação são medidas diretamente.

Numa retro-análise em solo saturado ou seco tem-se dois parâmetros de resistência a determinar, c' e $\phi$ ', e em solo não saturado tem-se uma incógnita a mais, $\phi^{\mathrm{b}}$. Para a determinação das incógnitas é preciso analisar várias superfícies de ruptura já acontecidas. No caso de solo saturado ou seco, quando é analisada só uma superfície de ruptura é possível encontrar várias respostas (Figura 2.30), tornando o problema indeterminado. Quando são analisados duas superfícies é possível obter uma única resposta (Figura 2.30), e quando são analisadas várias superfícies de ruptura (Figura 2.30), o problema é sobre-determinado, encontrando-se uma região de possíveis respostas que devem-se analisar estatisticamente. 


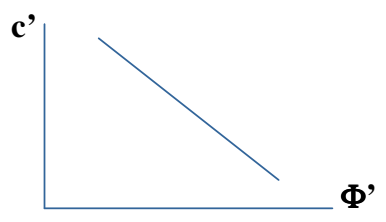

a) Indeterminado

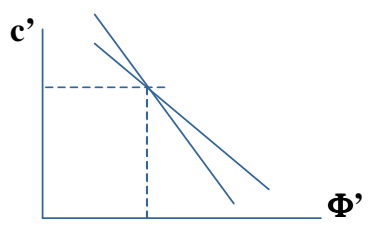

b) Determinado

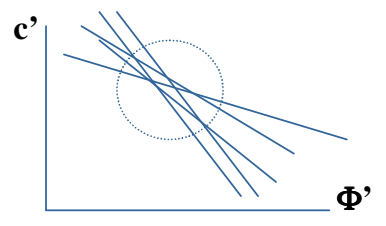

c) Sobre determinado

FIGURA 2.30 - Retro-análise para solos saturados ou secos.

Em solo não saturado a solução do problema é tridimensional, tornando a retro-análise complicada em sua resolução.

Yamagami et al. (1997) apresentou um método de retro-análise para a determinação dos parâmetros de resistência do solo não saturados. O método consiste em dois passos, o primeiro é obter duas superfícies de ruptura diferentes através de taludes de teste in situ, e o segundo, é realizar a retro-análise dos três parâmetros baseados na informação das duas superfícies de ruptura e o estado de sucção do talude.

A idéia básica é sugerida sobre a base de duas condições fundamentais que são essenciais para qualquer retro-análise: a) os parâmetros de resistência a determinar devem satisfazer a condição do fator de segurança igual a 1, e b) os parâmetros de resistência devem corresponder ao fator de segurança da superfície mais crítica de ruptura.

\subsubsection{TÉCNICAS DE RETRO-ANÁLISE}

No estudo da estabilidade de taludes naturais e artificiais os processos de instabilização envolvem fenômenos altamente complexos, que podem ser analisados segundo vários métodos empíricos ou analíticos. Tem-se métodos analíticos como os apresentados por Gioda (1985) e métodos observacionais ou racionais como o método de Hoek (1972).

\subsubsection{MÉTODOS ANALÍTICOS}

As retro-análises analíticas são freqüentemente utilizadas em Engenharia de Solos e Rochas para melhorar ou refinar a informação disponível relativa à análise de trabalhos geotécnicos complexos (Sakurai, 1983). Considerando que estes procedimentos são estritamente relacionados a aqueles comumente empregados para a solução de problemas de análise de tensões, apresentam-se em seguida, em forma sucinta, os passos a seguir numa análise de tensões para depois mostrar os métodos de retro-análise.

Qualquer análise de tensões no campo da Engenharia Geotécnica consiste em uma série de passos principais que podem ser resumidos como segue: 
- as características fundamentais, do ponto de vista do engenheiro, do sistema físico ou real a ser analisado são definidos em base da informação disponível "geral", assim como também dos dados adicionais obtidos por medidas in situ e/ou laboratório;

- o modelo numérico do sistema real é fixado por meio de uma técnica de modelagem satisfatória. Este modelo pode consistir em poucas equações (ex. de alguma solução simples da teoria da elasticidade) ou de um sistema grande de equações lineares ou não lineares descrevendo, por exemplo, o comportamento de uma discretização de elementos finitos do meio geotécnico;

- os valores dos parâmetros introduzidos no modelo numérico são escolhidos. Para este fim poderiam ser executadas medidas adicionais com respeito àqueles usados no passo (a); e

- o problema governado pelas equações desenvolvidas no passo (b) é resolvido e obtém-se, assim, as distribuições de deslocamentos, tensões (neutra e efetiva) e deformações.

Neste processo o engenheiro tem que enfrentar dois grupos de alternativas. O primeiro concerne a técnica de modelagem ou, em outras palavras, a escolha do:

- método de discretização, ex. diferenças finitas, elementos de contorno, elementos finitos, etc.;

- tipo de material, ex. uma fase (sólido) ou duas fases (sólido + fluido);

- modelo do material, ex. elástico, elastoplástico, viscoelástico, etc.;

- regime de deformações (pequenas ou grandes deformações); e

- outros.

O segundo grupo de alternativas concerne aos valores numéricos dos dados ingressados:

- dados geométricos definindo a forma do problema geomecânico, de possíveis camadas de solo ou rocha, de áreas carregadas ou confinadas, etc.;

- valores dos parâmetros mecânicos das leis constitutivas; e

- valores das cargas aplicadas, forças de massa e tensões in situ.

$\mathrm{Na}$ escolha das alternativas, as técnicas de modelagem estão principalmente baseadas na experiência e no juízo do engenheiro, sendo que os dados de entrada são estritamente relacionados à informação quantitativa disponível no sistema real. 
Em alguns casos esta informação é insuficiente para permitir uma definição completa dos dados de entrada com razoável precisão. A falta de informação pode se referir aos dados geométricos (ex. a geometria de uma camada pouco espessa de solo mole), os parâmetros mecânicos de algumas zonas do meio geotécnico, as distribuições de carga (ex. aquela devido a alguma estrutura que interage com o solo) ou o estado de tensões in situ.

Para superar este problema, testes adicionais in situ podem ser executados ou, no espírito do Método Observacional de Terzaghi (Peck, 1969), uma série de medidas, como deslocamentos por exemplo, é levado a cabo durante as fases iniciais da construção ou trabalhos de escavação. Os dados adicionais são usados para refinar os valores numéricos dos parâmetros utilizados, de forma que uma análise de tensões mais precisa do problema geotécnico pode ser executada com uma conseqüente modificação possível do projeto original. Os procedimentos que conduzem aos valores refinados dos parâmetros desconhecidos (ou apenas definidos) estão comumente referidos à Calibração ou técnicas de Retro-análise.

Em geral a retro-análise inicia-se como segue: definir os valores das quantidades desconhecidas do modelo numérico (geometria, parâmetros dos materiais, cargas) que, uma vez introduzidos na análise de tensões do sistema real, conduz a resultados (deslocamentos, tensões, etc.) tão próximos quanto possível aos correspondentes in situ.

Se a retro-análise tem êxito, e o modelo numérico utilizado é capaz de reproduzir as características fundamentais do sistema real, o modelo "calibrado" pode ser adotado em outras análises de tensões apontando a se antecipar ao comportamento do sistema real nessas situações.

Os problemas de retro-análise são resolvidos, em princípio, de duas formas possíveis, o método "inverso" e o método "direto".

O método inverso requer uma formulação contrária à adotada na análise de tensões. As equações que governam o problema da análise de tensões são "invertidas" de forma que algumas das quantidades que são desconhecidas na análise de tensões, e aquelas correspondentes às medidas disponíveis, aparecem no grupo de dados, enquanto outras quantidades, contendo valores conhecidos na análise de tensões (ex. módulo elástico), aparecem no grupo das desconhecidas. Na maioria dos casos práticos o número de medidas in situ excede o número de parâmetros desconhecidos. Isto conduz a um sistema de solução que tem mais equações que incógnitas que são resolvidos por meio de uma técnica de minimização satisfatória.

A formulação adotada no método de calibração direta é idêntica àquela da análise de tensões. Neste caso o problema de retro-análise é resolvido utilizando um procedimento de 
minimização que permite corrigir os valores experimentais dos parâmetros desconhecidos ingressados no algoritmo da análise de tensões, até que a discrepância entre as medidas experimentais e os resultados numéricos correspondentes são minimizados.

Uma distinção adicional entre os procedimentos de retro-análise pode ser introduzida considerando os métodos "determinísticos" e "probabilísticos" separadamente (Beliveau, 1976; Asaoka \& Matsuo, 1979).

Os métodos determinísticos podem ser úteis aplicados na prática se são executadas medidas de alta precisão ou quando a estrutura matemática do método é "estável" com respeito ao possível erro que afeta os dados utilizados. Pelo contrário, o uso de métodos probabilísticos é obrigatório quando as "incertezas" das medidas experimentais tem uma considerável influência nos resultados dos cálculos.

\section{Método inverso}

Como mencionou-se, este método requer a "inversão" das equações que governam o problema da análise de tensões. Porem, diferentes procedimentos de solução têm que ser desenvolvidos para os problemas de calibração, dependendo das características da técnica de modelagem adotada e do tipo de parâmetros a ser retro calculado.

\section{Método direto}

O método direto representa um modo alternativo para resolver problemas de calibração, com respeito aos procedimentos inversos previamente discutidos, baseado na minimização direta da discrepância que existe entre as medidas de campo e as quantidades correspondentes obtidas por meio de um modelo numérico satisfatório do sistema real. Portanto, esta aproximação não precisa da "inversão" das equações da análise de tensões que são requeridas pela técnica ilustrada na seção anterior.

A seguinte função de erro $\in$ pode ser adotada como uma definição prática da discrepância mencionada:

$$
\in=\sum_{1}^{\mathrm{m}}{ }_{\mathrm{i}}\left(\mathrm{u}_{\mathrm{i}}-\mathrm{u}_{\mathrm{i}}^{*}\right)^{2}
$$

Onde $u_{i}{ }^{*}$ denota a medida i-ésima, e $u_{i}$, é a quantidade calculada correspondente. Claramente outras definições são possíveis.

A função de erro depende, dos resultados numéricos $\mathrm{u}_{\mathrm{i}}$, porem, dos parâmetros $\mathrm{p}$ a ser retro-analisados (notar que neste contexto os parâmetros têm um significado bastante geral e podem corresponder a propriedades do material, a características geométricas ou a valores de carga). Então a retro-análise se reduz à determinação dos parâmetros p que minimizam o erro 
$\epsilon$ ou, em outras palavras, a determinação dos parâmetros que conduzem à melhor aproximação do comportamento do sistema real pelo modelo numérico escolhido.

\subsubsection{MÉTODOS OBSERVACIONAIS}

Visando a economia na exploração e uma análise rápida na segurança de taludes, desenvolveram-se ábacos de projeto, baseados em observações do comportamento de maciços. Esses ábacos foram obtidos, plotando-se em um gráfico inclinação versus altura para taludes críticos.

Newman, apud Hoek (1972), publicou em 1890, um manual para engenheiros civis ingleses, onde fornece conselhos práticos sobre inclinações e alturas de taludes provenientes de aterros de diversos tipos de terreno, dando também sugestões acerca da drenagem e da utilização de perfil curvo, exigido para garantir a estabilidade.

Shuk (1965) descreveu um estudo de estabilidade de taludes naturais em folhelhos ferruginosos, pertencentes à Formação Villera, a $60 \mathrm{~km}$ de Bogotá, Colômbia, nos quais uma relação entre a inclinação e a altura de talude foi estabelecida, com base nas observações de campo.

Rana \& Bullock (1969) com base em observações de campo, de taludes em quartzitos e ardósias da Iron Ore Company of Canada, em Quebec, Canada, obtiveram uma curva média inclinação versus altura de taludes, para projeto, considerando um fator de segurança igual a 1,10 (Figura 2.31)

Procedimentos similares foram adotado por Lutton (1970), a partir da análise dos dados de um grande número de minas a céu aberto. Neste caso, os dados coletados foram plotados em um gráfico inclinações versus alturas para os taludes mais íngremes das minas, (Figura 2,32). Uma análise estatística foi conduzida na tentativa de se encontrar leis gerais de projeto. 


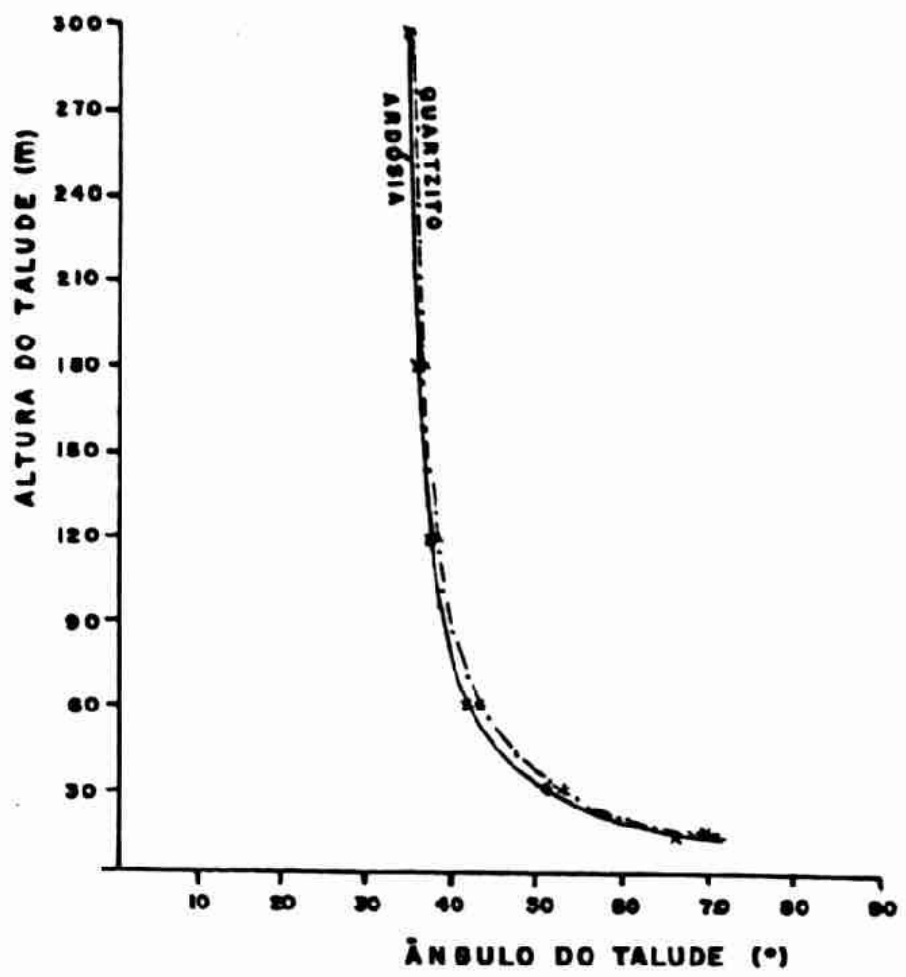

FIGURA 2.31- Curvas para projeto de taludes, com fator de segurança igual a 1,10 em ardósias e quartzitos (Fonte: Rana \& Bullock, 1969).

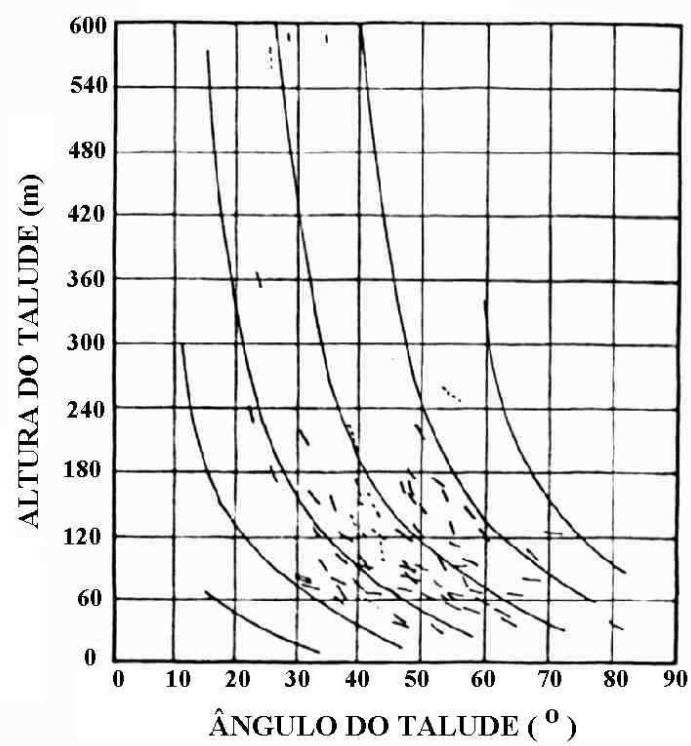

FIGURA 2.32- Curvas médias representativas de inclinações versus alturas de taludes (Fonte: Lutton, 1970). 
Barton (1971), apud Gama (1984), desenvolveu a partir da observação de cerca de 50 taludes escavados na mina de Atalaya, da Rio Tinto Espanhola, e assinalado em um gráfico de inclinação versus altura dos taludes (Figura 2,33), quais aqueles taludes que se mantiveram estáveis e aqueles que se revelaram instáveis.

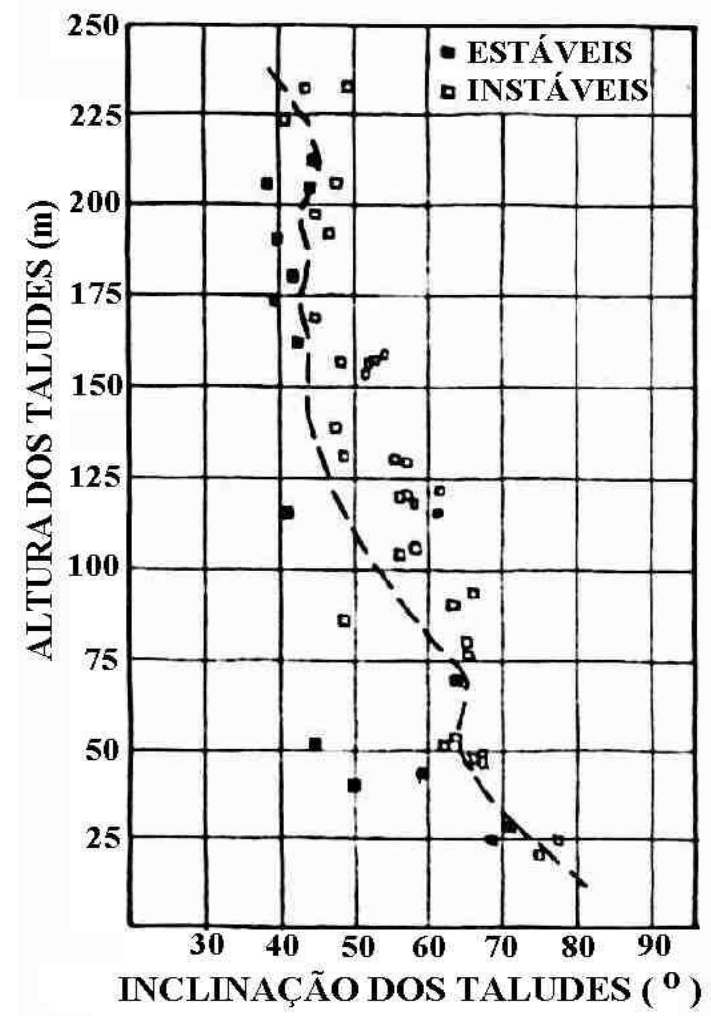

FIGURA 2.33- Gráfico de variação de inclinação versus altura de taludes (Barton, 1971).

Kanji et al. (1976) cita que "a teoria decorrente da observação de taludes em solo, permitiu o desenvolvimento de ábacos de projeto por Taylor (1948), Janbu (1954), Bishop \& Morgenstern (1960) e Spencer (1967)"

Hoek (1972) elaborou ábacos de projeto de taludes em solos e rochas brandas e em rochas duras fraturadas, que são expressos através de parâmetros adimensionais que permitem uma avaliação quantitativa da estabilidade de taludes sob determinadas condições. A precisão dos resultados é, de modo geral, compatível com a dos dados de entrada disponíveis.

O método permite avaliar a variação da estabilidade de um talude particular, frente a alterações de inclinação, altura, parâmetros dos materiais e condições hidro-geológicas. O trabalho tem, ainda, a vantagem de permitir a análise regressiva do fenômeno, ou seja, a partir do estudo de taludes em diversas condições de equilíbrio, chegar-se a valores médios aproximados de c (coesão) e $\phi$ (ângulo de atrito interno). No procedimento, é preciso analisar várias superfícies de ruptura como mencionou-se anteriormente. Para a primeira superfície de 
ruptura assumem-se vários valores de $\phi$ ', e com cada valor de $\phi$ ' determina-se a coesão c' da seguinte maneira, na Figura 2.35 determina-se a função ângulo do talude X, correspondente ao caso analisado, depois na Figura 2.34, assumindo-se um fator de segurança igual a 1, determina-se a função altura do talude $\mathrm{Y}$, e com este valor na Figura 2.35 determina-se a coesão $c^{\prime}$.

Com os valores obtidos de $c^{\prime}$ e $\phi^{\prime}$ plota-se a curva de retro-análise correspondente à primeira superfície de ruptura analisada, e repete-se o processo para as outras superfícies de ruptura até obter um resultado de c' e $\phi^{\prime}$ ou uma região de possíveis resultados que possam ser analisados estatisticamente.

Nos Congresso da ABGE. (Associação Brasileira de Geologia de Engenharia), vários trabalhos têm versado sobre o assunto e entre eles podem ser encontrados alguns que defendem uma linha tipicamente "observacionista" e "fenomenológica", como os de Santos (1976) e Carlstron filho \& Salomão (1976). Por outro lado, alguns buscam estabelecer "pontes" entre os métodos "observacionais" e os "racionais". Neste último grupo, situam-se os trabalhos de Kanji et al. (1976) e Cachapuz (1978), que são aplicações dos conceitos de Hoek (1972).

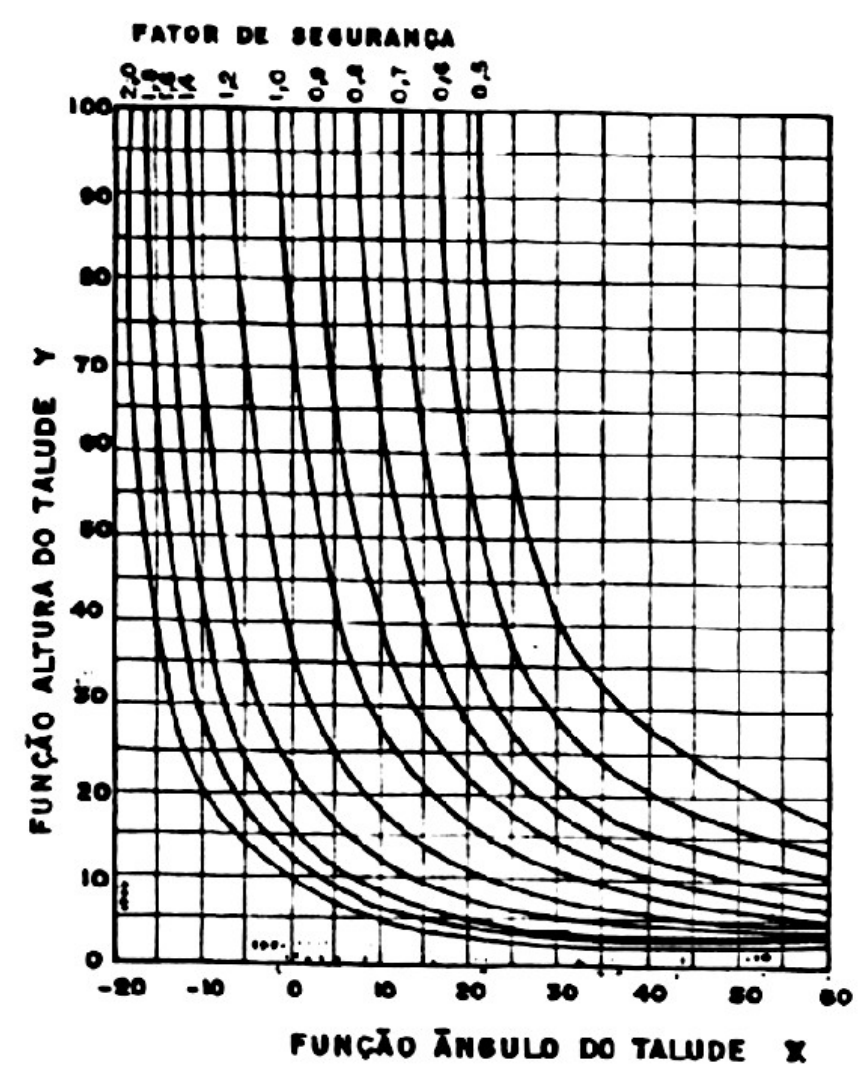

FIGURA 2.34- Ábaco de ruptura circular (Fonte: Hoek, 1972). 


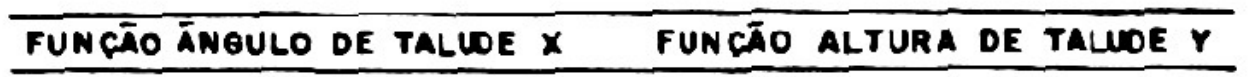

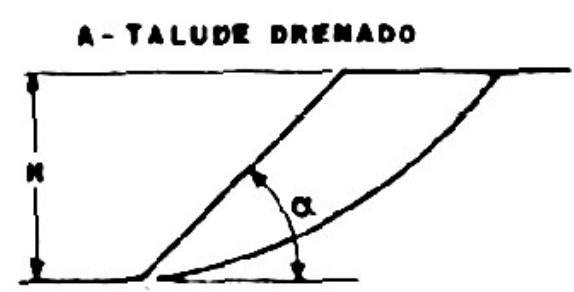

- - een temoa de tanacto

$x=0-1,2, \bullet$

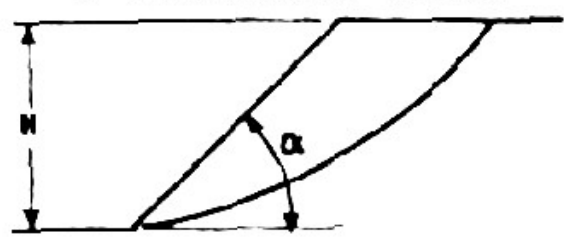

$r=\gamma \cdot \boldsymbol{H} / \mathrm{C}$
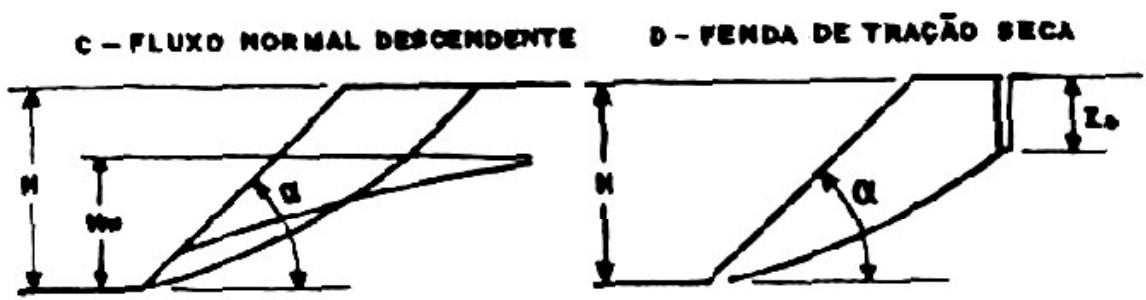

$X=\alpha-\alpha \cdot\left(1,2-0,3 \cdot \frac{H}{H}\right) \quad Y=\left(1+\left(\frac{\alpha-25}{100}\right) \cdot \frac{20}{H}\right) \cdot \frac{X \cdot H}{C}$

E- muxo oe doun monizontal

- P-tenda de tragio raekmenion ce heva
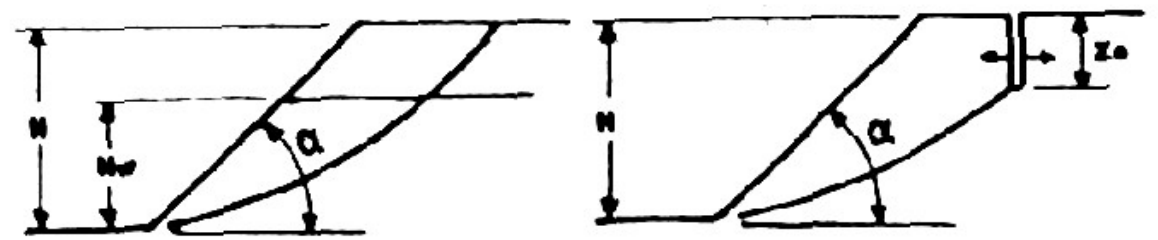

$$
x \cdot \alpha-0\left[1,2-0,8 \cdot \frac{N H}{H}\right]
$$$$
r=\left(1+\left(\frac{\alpha-10}{100}\right) \frac{Z 0}{H}\right) \frac{r \cdot H}{c}
$$

(FUNCIO DO M.A.)

(FUNCTO DE Z.) 


\section{MATERIAIS E MÉTODOS}

\subsection{CARACTERÍSTICAS GERAIS DO TALUDE ESTUDADO}

O talude estudado localiza-se na Rodovia Engenheiro Thales de L. Peixoto - SP 318, Km 261 (Rodovia que liga São Carlos e Ribeirão Preto), e posiciona-se nas coordenadas $7590.47 \mathrm{~km} \mathrm{~N}$ e $200.2 \mathrm{~km}$ E, correspondente a folha SF-23-V-C-IV-3, IBATÉ, do Instituto Brasileiro de Geografia e Estatística (IBGE), 1971.

Segundo dados do DAEE (1975), o índice de precipitação média da região é da ordem de 1350mm/ano. O período chuvoso está compreendido entre outubro e março, com temperaturas médias que variam entre 22 e $26^{\circ} \mathrm{C}$ e umidade relativa do ar variando entre 50 a $80 \%$. No período seco, de abril a setembro, as temperaturas médias permanecem em torno de 13 a $16^{\circ} \mathrm{C}$ com umidade relativa variando de 20 a $60 \%$.

No local ocorrem Basaltos da Formação Serra Geral sobrejacente à formação Botucatu.

A formação Botucatu é freqüentemente descrita na literatura (Fúlfaro et al, 1980; Soares et al,1971; IPT,1980) como uma unidade constituída por arenito de granulação fina à média, uniforme, localmente composto por corpos lenticulares de arenitos heterogêneos, de granulação média à grossa, passando a arenitos conglomeráticos sobretudo nas partes baixas do pacote.

As rochas da formação Serra Geral são constituídas por derrames basálticos entre os quais se intercalam arenitos pertencentes à formação Botucatu, por vezes associados à corpos intrusivos de diabásio constituindo sobretudo diques e sills (IPT, 1981).

O talude em análise está formado por solo residual, apresentando como minerais principais caolinita e óxidos e hidróxidos de ferro e alumínio, podendo-se classificá-lo como uma areia argilosa marrom, de baixa compacidade.

Detalhes do escorregamento e topografia do talude, incluindo a localização da amostragem, tensiômetros e sondagens apresentam-se na Figura 3.1. Encontra-se também nessa figura a superfície provável de escorregamento obtida através de observações de campo e da estimativa dos volumes do solo deslocado. Essa superfície principia no pé da fenda de 
tração e desenvolve-se de forma aproximadamente circular, passando pelo pé do talude. Um circulo de centro $(21,28)$ e raio $19,9 \mathrm{~m}$, com uma área aproximada de escorregamento de $50,6 \mathrm{~m}^{2}$.

a)

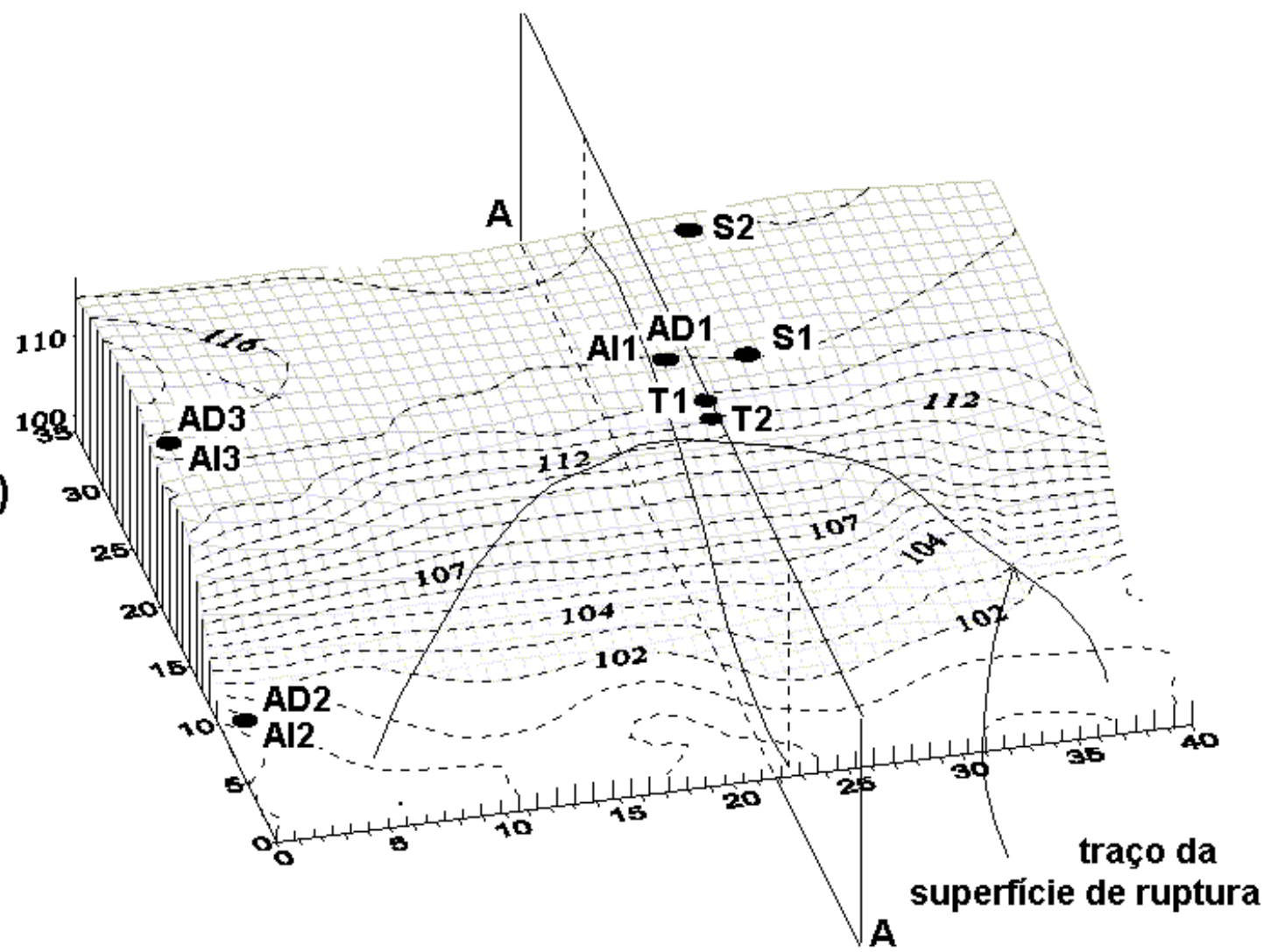

b )

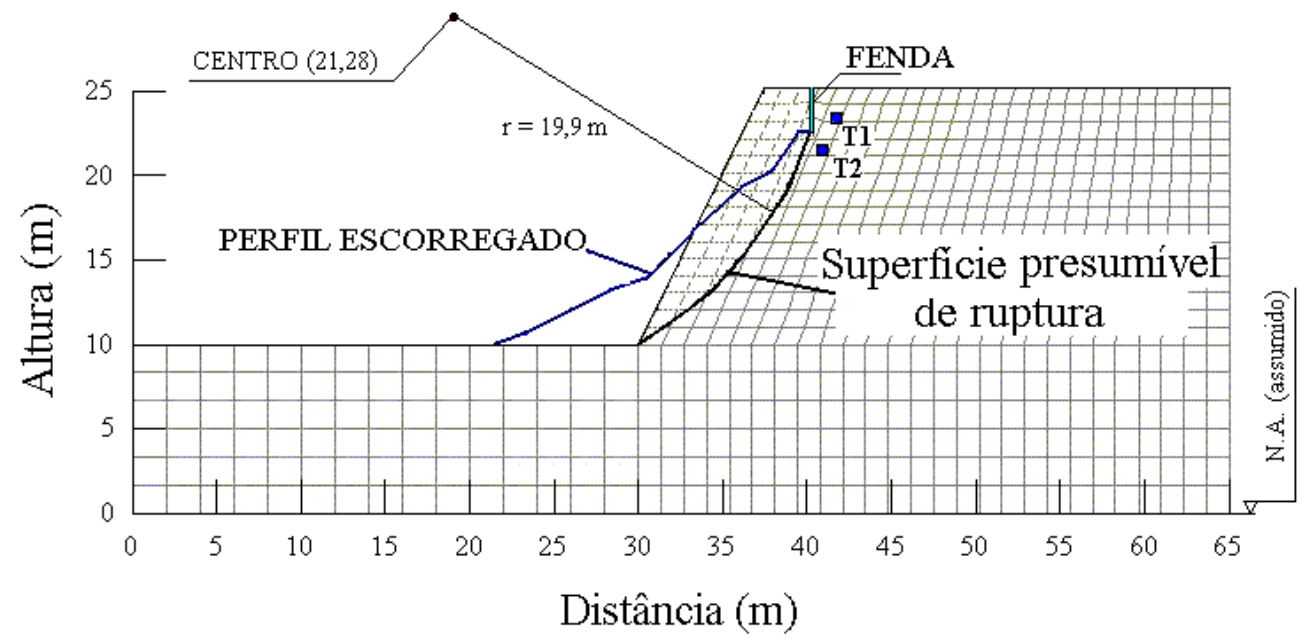

$A D$ - Amostra deformada;

AI - Amostra indeformada;

$T$ - Tensiōmetro;

$S$ - Sondagem

\section{SEÇĀO A - A}

FIGURA 3.1 - Elementos do talude em análise: a) Vista tridimensional; b) Perfil do escorregamento. 
Na Figura 3.2 mostra-se o talude escorregado. Na Figura 3.3 apresenta-se uma vista do escorregamento panorâmico. Na Figura 3.4 mostra-se um detalhe da fenda de tração que continua ao longo do talude ainda não escorregado e que foi parte do talude que escorregou. $\mathrm{Na}$ Figura 3.5 mostra-se um escorregamento superficial, comum em taludes íngremes, localizado do lado direito do talude escorregado.

Os elementos geométricos do talude e da ruptura foram obtidos através de levantamentos plani-altimétricos.

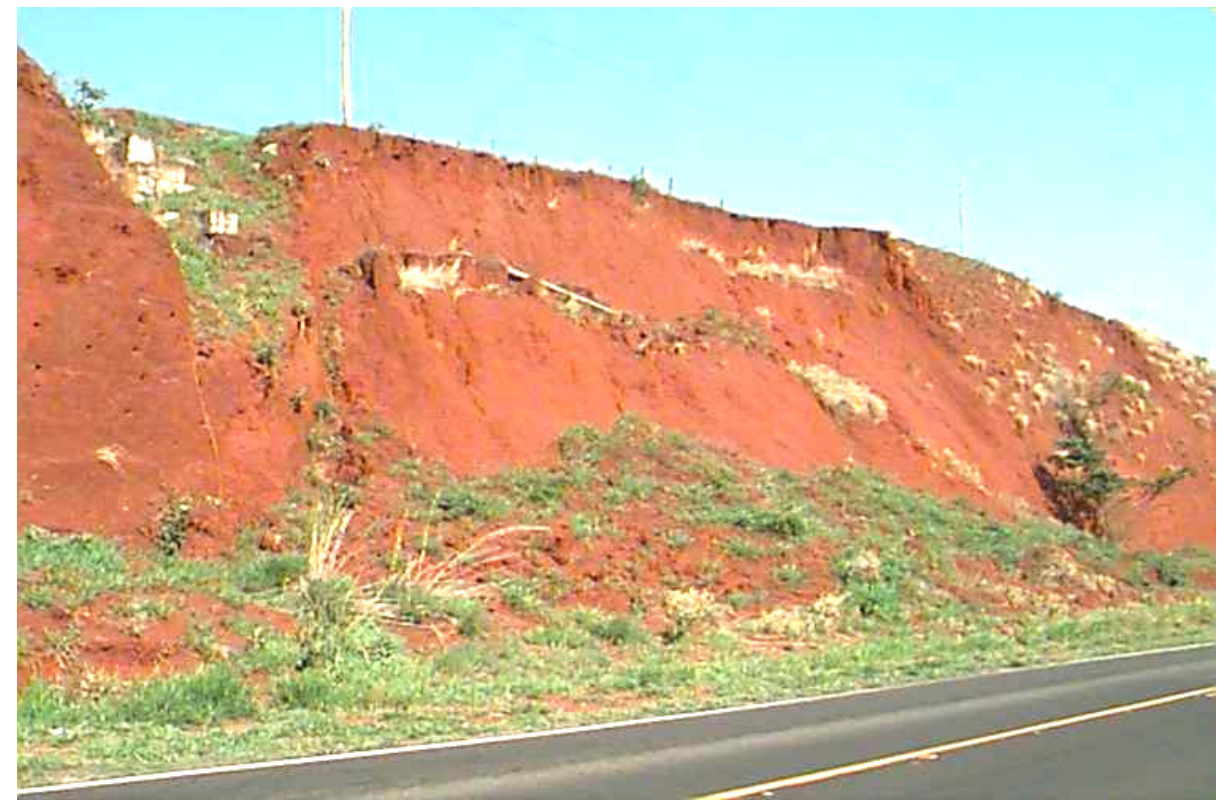

FIGURA 3.2- Vista do talude escorregado.

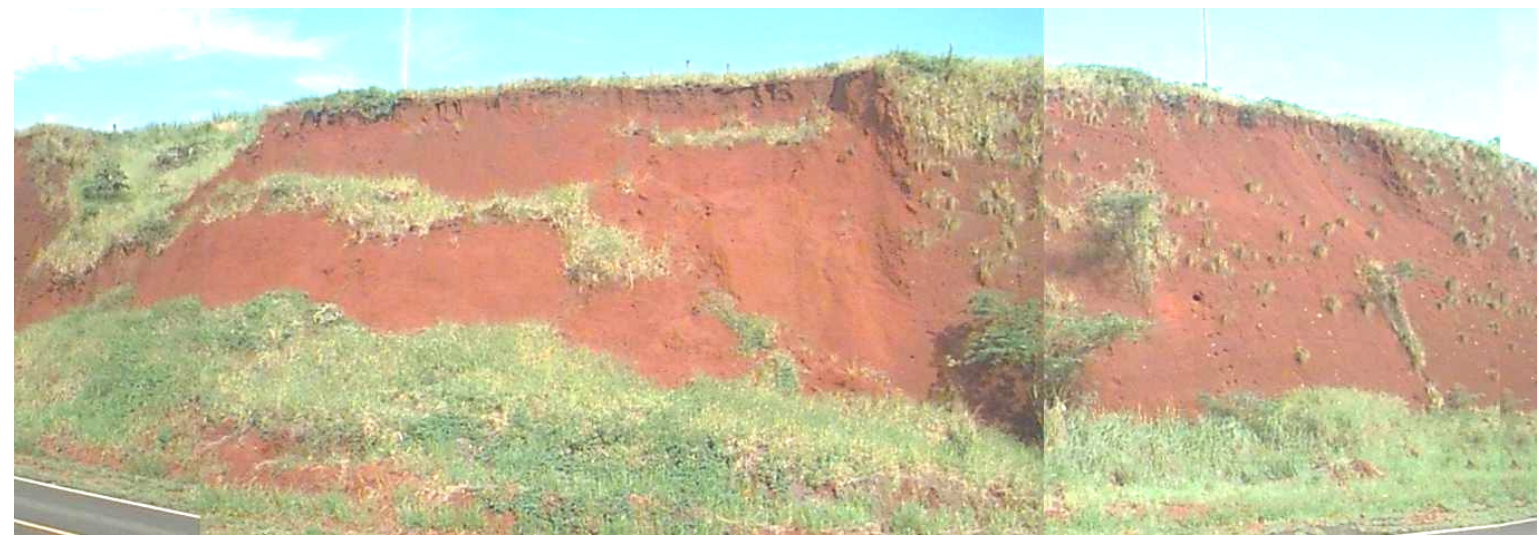

FIGURA 3.3- Vista do escorregamento panorâmico. 


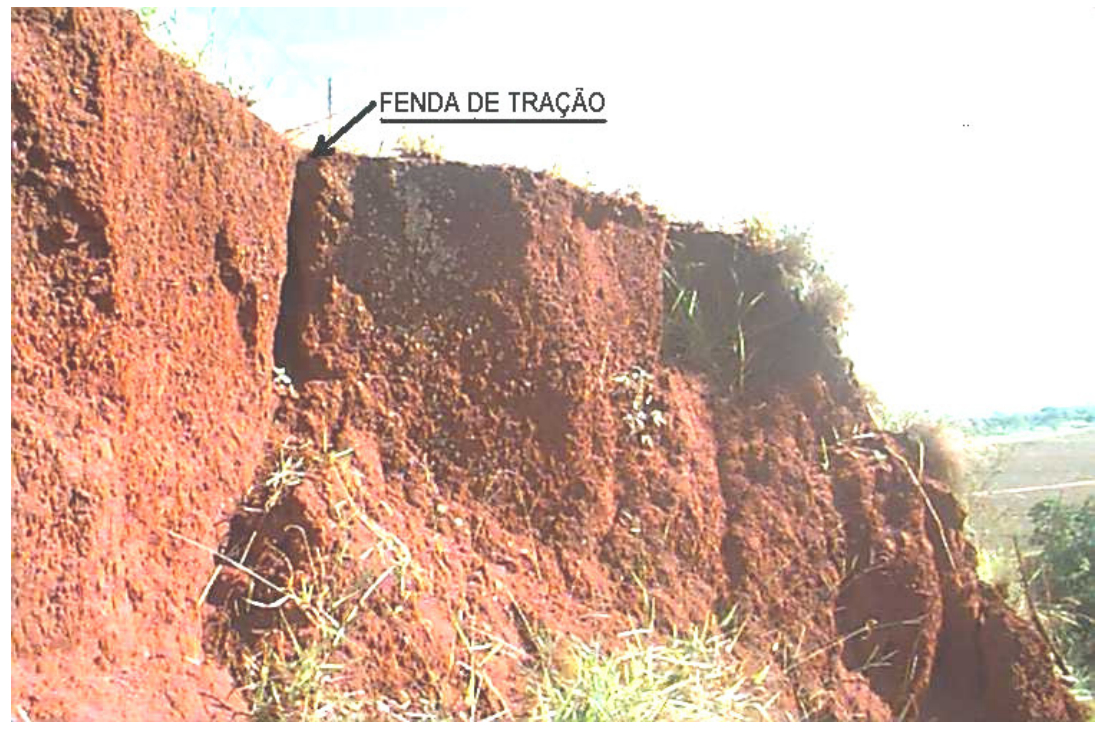

FIGURA 3.4- Detalhe da fenda encontrada em campo.

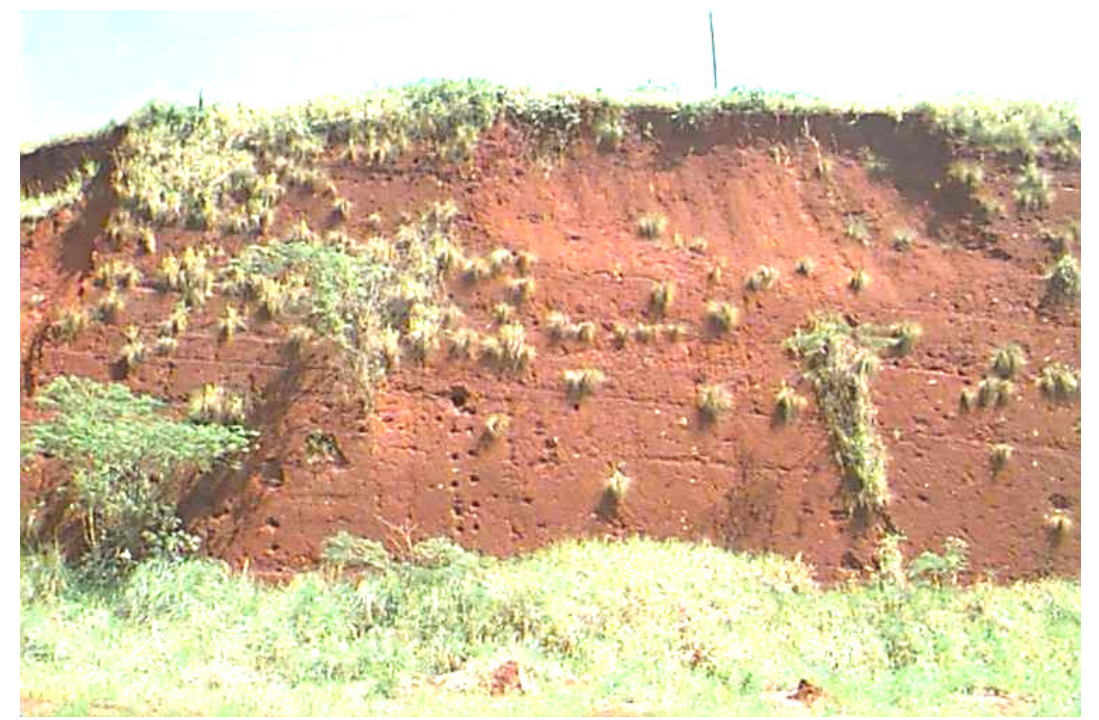

FIGURA 3.5- Detalhe de um escorregamento superficial.

\subsection{RECONHECIMENTO GEOTECNICO}

O reconhecimento geotécnico do local baseou-se na realização de duas sondagens de simples reconhecimento (Figura 3.1), com medida de $N$ do SPT (NBR 6484) e ensaios de caracterização, a cada metro de profundidade. Utilizou-se um trado cavadeira para o primeiro metro e um trado espiral para os restantes 19 metros. A sondagem S1 foi feita em seco e a sondagem S2 foi feita saturando o solo, com o propósito de avaliar a influência do incremento de umidade na resistência, através do SPT. 


\subsection{COLETA DE AMOSTRAS DEFORMADAS E INDEFORMADAS EM CAMPO}

As amostras deformadas e indeformadas foram retiradas de três locais de amostragem localizadas no topo e na base do talude (Figura 3.1). De cada local de amostragem, coletou-se dois blocos indeformados com $25 \mathrm{~cm}$ de lado, aproximadamente a $1,5 \mathrm{~m}$ de profundidade.

\subsection{ENSAIOS DE CARACTERIZAÇÃO}

Como parte da caracterização do solo, foram determinados valores de limite de liquidez (NBR 6459/84), limite de plasticidade (NBR 7180/84), massa específica (NBR 6508/84) e análise granulométrica (NBR 7181/84), para cada local amostrado e para cada metro de profundidade das sondagens realizadas.

\subsection{OBTENÇÃO DA CURVA DE RETENÇÃO DA ÁGUA DO SOLO}

Foram realizados ensaios para determinação das curvas de retenção do solo indeformado. Na determinação da curva de retenção de água do solo, empregou-se a trajetória de drenagem e utilizou-se a técnica de papel filtro e da câmara de pressão (Anexos B e C).

$\mathrm{Na}$ técnica de papel filtro, primeiramente moldaram-se corpos de prova, indeformados, em anéis de PVC de $3 \mathrm{~cm}$ de diâmetro por $1 \mathrm{~cm}$ de altura. Em seguida, após saturação, foram deixados secar ao ar até diferentes umidades. Em cada um dos corpos de prova colocou-se tanto no topo quanto na base, uma lâmina circular de $3 \mathrm{~cm}$ de diâmetro de papel filtro Whatman No 42 (ASTM D5298). O conjunto papel filtro, solo e anel, foi envolvido com papel filme impermeável, hermeticamente fechado, e o conjunto foi levado à câmara úmida por 15 dias aproximadamente. Determinou-se, após esse tempo, a umidade do solo e do papel filtro de cada corpo de prova. Com a umidade do papel filtro é inferida a sucção matricial do solo segundo a norma ASTM D5298 (Tabela 2.1); e tem-se então os pares de valores umidade do solo e sucção matricial, que permitem obter a curva de retenção de água.

Na câmara de pressão a sucção matricial é aplicada elevando-se a pressão de ar e mantendo-se a pressão de água igual à atmosférica. A sucção matricial corresponde portanto à pressão de ar, visto que a pressão na água é zero. No ensaio, empregaram-se pressões de ar de $10,50,100,300$ e $400 \mathrm{kPa}$ em corpos de prova de $5 \mathrm{~cm}$ de diâmetro por $1 \mathrm{~cm}$ de altura, que previamente foram saturados. Uma vez aplicada a sucção matricial, os corpos de prova eram pesados sistematicamente até a sua constância de peso, dentro de determinada tolerância $(0,001 \mathrm{~g})$. O tempo para estabilização do peso dos corpos de prova variou de 15 dias a um mês, 
para cada valor de sucção matricial aplicado. A umidade para cada estagio de sucção matricial foi inferida considerando-se as características iniciais dos corpos de prova ( $n, w_{o}, \rho, \rho_{\mathrm{s}}$ e $\rho_{d}$ ). Na Figura 3.6 podem-se observar duas câmaras de pressão e os manômetros correspondentes, a câmara da direita é empregada para sucções matriciais menores que $500 \mathrm{kPa}$ e a outra para sucções matriciais menores que $15000 \mathrm{kPa}$.

Os pontos experimentais foram ajustados de acordo com o modelo de Van Genutchen (equação 2.6), utilizando-se o programa CURVARET (Van Lier \& Neto, 1991).

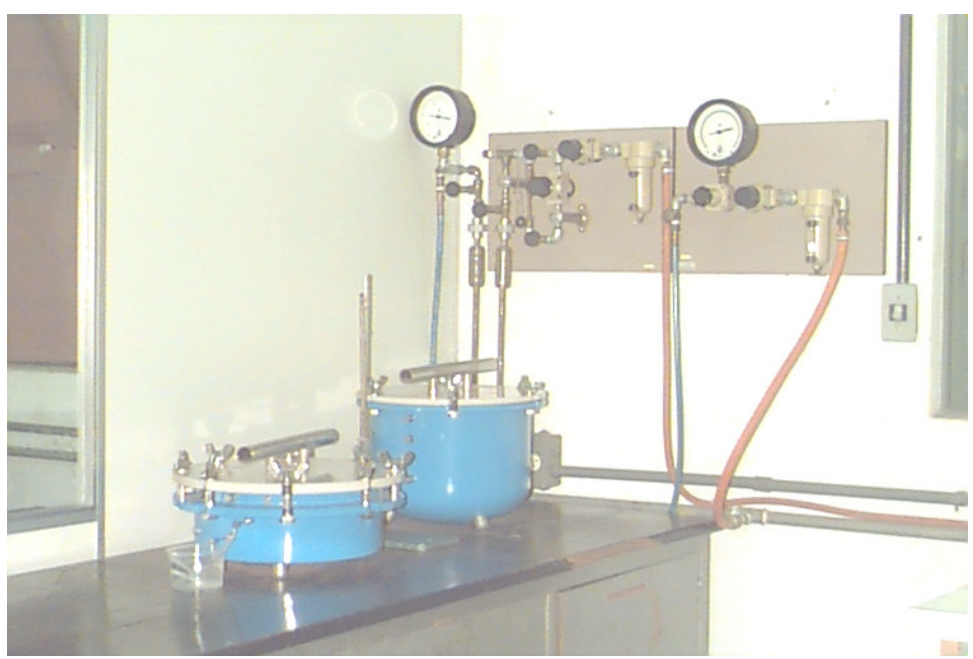

FIGURA 3.6 - Câmaras de pressão usadas para determinar a curva de retenção.

\subsection{CONTROLE DE SUCÇÃO MATRICIAL EM CAMPO}

O controle de sucção matricial em campo realizou-se mediante a utilização de dois tensiômetros, localizados próximos a base da fenda de tração do talude escorregado (Figura 3.1).

\subsection{OBTENÇÃO DA CURVA DE CONDUTIVIDADE HIDRÁULICA NÃO SATURADA}

a) Determinação do coeficiente de condutividade hidráulica saturada em laboratório

Os ensaios para determinação do coeficiente de condutividade hidráulica saturada no laboratório foram realizados utilizando ensaios de permeabilidade com carga variável. No procedimento foram utilizados corpos de prova obtidos a partir do bloco indeformado AI1, talhados em forma cilíndrica. As dimensões dos mesmos foram de $5 \mathrm{~cm}$ de diâmetro e $10 \mathrm{~cm}$ de altura. 
Os corpos de prova foram percolados com água até a constância das leituras, quando então se registraram os valores para o cálculo da condutividade.

b) Ensaios com Permeâmetro Guelph para determinação da condutividade hidráulica na condição saturada, potencial matricial de fluxo e o parâmetro $\alpha$, em campo.

Para obtenção dos parâmetros $\left(\mathrm{K}_{\mathrm{s}}, \phi_{\mathrm{Gm}} \mathrm{e} \alpha\right)$ correspondentes à solução apresentada na equação (2.19), utilizou-se o método de duas alturas de carga (Reynolds e Elrick, 1985), de acordo com as equações 2.28 a 2.33. Para o cálculo de $\alpha$ utilizou-se a equação simplificada de Scotter (1982), (equação 2.21).

Os ensaios baseados nestas técnicas foram realizados nos locais de amostragem AI1 e AI3. Executou-se em cada local, um ensaio com duas alturas de carga de 5 e $10 \mathrm{~cm}$. Na Figura 3.7 pode-se ver o permeâmetro de Guelph instalado em campo.

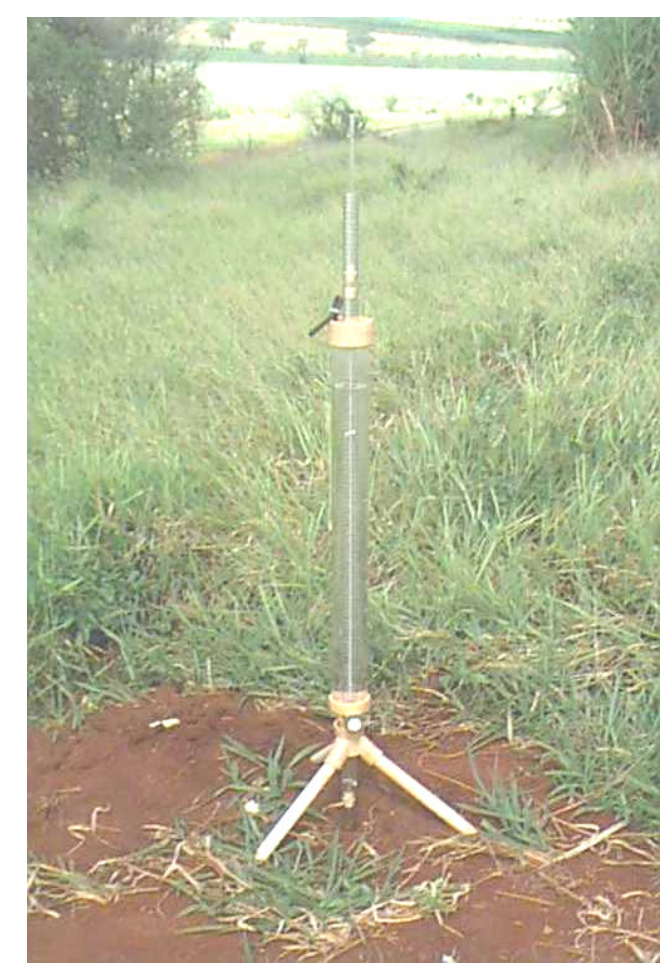

FIGURA 3.7 - Ensaios realizados com o Permeâmetro Guelph no local AI1.

c) Procedimento para duas alturas de carga (Reynolds e Elrick, 1985)

- Preparação do furo de ensaio com $6 \mathrm{~cm}$ de diâmetro. Nesta fase, deve-se cuidar do acabamento das paredes do furo e na base evitando o fechamento dos poros ou a 
compactação do solo por aplicação de uma força excessiva provocado pelo processo de tradagem.

- Montagem e abastecimento de água no reservatório do permeâmetro sem permitir a saída de água (ponteira de saída de água fechada pela ponteira de ar como mostra-se na Figura 3.8 a.

Neste procedimento deve-se ter cuidado em abastecer de água o permeâmetro antes de posicionar o equipamento no furo de sondagem, impedir o fluxo a partir do reservatório e usar a bomba de vácuo para evitar quedas de água intempestivas que produzem alagamentos nos furos de sondagem danificando os ensaios. $\mathrm{O}$ vácuo aplicado foi de 20 centibar.

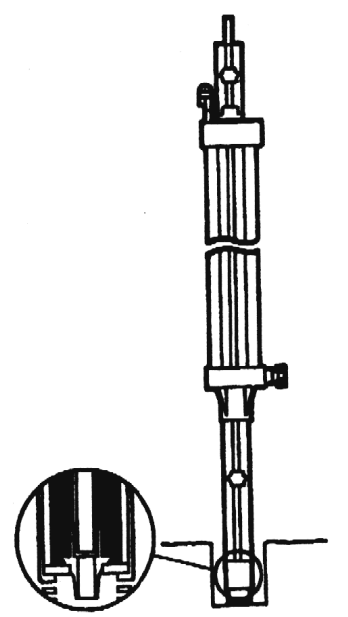

(a)

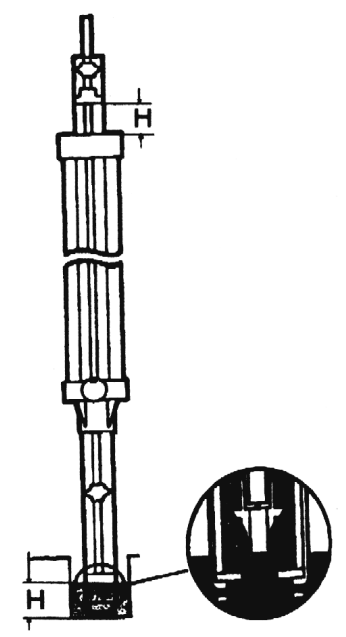

(b)

FIGURA 3.8- Ponteira de água do Permeâmetro Guelph a) Permeâmetro sem saída de água; b)

Permeâmetro com saída de água.

- Posicionamento do permeâmetro no furo de sondagem. Nesta fase deve-se evitar golpear ou fragmentar as paredes e base do furo de sondagem .

- Estabelecimento da altura de carga constante correspondente a um estágio. A altura desde a base do furo até a ponteira de ar determina a altura de carga constante de água como é mostrado na Figura 3.8b. O levantamento da ponteira (imposição da altura de carga H) é controlado através de uma escala graduada desde 0 a $25 \mathrm{~cm}$, no permeâmetro.

Nesta fase o maior cuidado deve ser tomado no levantamento da ponteira de ar para estabelecer a altura de carga, este procedimento deve ser lentamente executado para evitar turbulência e portanto erosão no furo de ensaio.

- O ensaio é finalizado após atingir fluxo em regime permanente. Para esse objetivo o fluxo de saída de água do permeâmetro para o solo é indicado pelos registros da razão de 
queda do nível de água no reservatório graduado, em intervalos de tempo regulares $\mathrm{R}(\mathrm{cm} / \mathrm{s})$. Quando a razão de queda de água no reservatório é constante por 3 leituras consecutivas pode-se dizer que o fluxo é constante ou foi atingido o regime permanente.

- Estabelecimento da segunda altura de carga constante correspondente ao segundo estágio. Para a segunda altura de carga, a ponteira de ar é elevada à altura maior desejada, estabelecida através de escala graduada no permeâmetro.

\subsection{ENSAIOS DE COMPRESSÃO TRIAXIAL}

Para avaliação da resistência ao cisalhamento do talude escorregado, foram realizados ensaios triaxiais convencionais, saturados (CD) e não saturados (UU), em conjunto com ensaios triaxiais com controle de sucção matricial. Os ensaios foram realizados em amostras indeformadas obtidas a partir dos blocos coletados na profundidade de $1,5 \mathrm{~m}$, a contar da superfície, do topo do talude [AI1] e da base do talude [AI2] (Figura 3.1). Os corpos de prova, para os ensaios triaxiais foram obtidos por talhagem dos blocos indeformados, utilizando-se para isto um berço para o ajuste da altura do corpo de prova a $10 \mathrm{~cm}$, e um torno manual para o ajuste do diâmetro do corpo de prova a $5 \mathrm{~cm}$. Determinaram-se também a umidade, dimensões e densidade natural inicial de cada corpo de prova moldado. O método de execução empregado em cada tipo de ensaio é apresentado nos itens a seguir.

\subsubsection{ENSAIOS TRIAXIAIS CONVENCIONAIS}

Foram realizados ao todo treze ensaios triaxiais consolidado - drenado (CD), saturados por contra pressão, para definição da envoltória de resistência do solo saturado. Seis corpos de prova foram extraídos da amostra indeformada do topo e sete da base. Durante o processo de saturação, admitiu-se como saturadas amostras possuindo o parâmetro "B" de Skempton superior a 0,95 . Atingindo-se um valor de B contido na faixa previamente estipulada, as amostras foram adensadas e rompidas no dia posterior. $\mathrm{O}$ valor da velocidade de cisalhamento foi fixado em $0,06 \mathrm{~mm} / \mathrm{min}$, a partir das características de adensamento dos corpos de prova.

Também foram realizadas doze ensaios triaxiais rápido (UU), em amostras com teor de umidade natural. Seis corpos de prova foram extraídos de amostras indeformadas do topo e seis da base. $O$ valor da velocidade de cisalhamento foi fixado em $0,5 \mathrm{~mm} / \mathrm{min}$.

As Tabelas 3.1 e 3.2 apresentam as condições de ensaio para as amostras obtidas dos blocos indeformados do topo e da base, incluindo-se o tipo de instrumento utilizado. 
TABELA 3.1 - Condições do ensaio CD, saturado por contra pressão.

\begin{tabular}{|c|c|c|c|}
\hline & Local & $\sigma^{\prime}{ }_{3 \mathbf{c}}(\mathbf{k P a})$ & Instrumento \\
\hline CP1 & topo & 50 & GDS \\
\hline CP2 & topo & 120 & GDS \\
\hline CP3 & topo & 150 & GDS \\
\hline CP4 & topo & 50 & Convencional \\
\hline CP5 & topo & 100 & Convencional \\
\hline CP6 & topo & 150 & Convencional \\
\hline CP7 & base & 50 & GDS \\
\hline CP8 & base & 50 & GDS \\
\hline CP9 & base & 100 & GDS \\
\hline CP10 & base & 150 & GDS \\
\hline CP11 & base & 50 & Convencional \\
\hline CP12 & base & 100 & Convencional \\
\hline CP13 & base & 150 & Convencional \\
\hline
\end{tabular}

$\sigma_{3 c}^{\prime}$ : tensão efetiva de adensamento.

TABELA 3.2 - Condições do ensaio UU, rápido, em umidade natural.

\begin{tabular}{|c|c|c|c|}
\hline & Local & $\boldsymbol{\sigma}_{\mathbf{3 c}}(\mathbf{k P a})$ & Instrumento \\
\hline CP1 & topo & 50 & GDS \\
\hline CP2 & topo & 100 & GDS \\
\hline CP3 & topo & 200 & GDS \\
\hline CP4 & topo & 50 & Convencional \\
\hline CP5 & topo & 100 & Convencional \\
\hline CP6 & topo & 150 & Convencional \\
\hline CP7 & base & 50 & GDS \\
\hline CP8 & base & 100 & GDS \\
\hline CP9 & base & 150 & GDS \\
\hline CP10 & base & 50 & Convencional \\
\hline CP11 & base & 100 & Convencional \\
\hline CP12 & base & 150 & Convencional \\
\hline
\end{tabular}

$\sigma_{3 c}$ : tensão total de confinamento

Nas Tabelas 3.1 e 3.2 pode-se observar que foram empregados dois tipos de equipamentos na realização dos ensaios de compressão triaxial, o equipamento convencional e o equipamento GDS. Nos ensaios convencionais utilizou-se um equipamento que proporciona as pressões através de colunas de mercúrio e aquisição automática de dados (Figura 3.9). No entanto, no GDS as pressões são transmitidas através de atuadores de pressão hidráulica, que estão conectados a um computador através de cabos. Estes transmitem a informação que é processada e controlada por um software do próprio equipamento. Na Figura 3.10 mostram-se os três atuadores de pressão, a câmara triaxial de Bishop-Wesley, a interface, os cabos da interface e o computador. Na Figura 3.11 mostram-se com maior detalhe os atuadores de pressão, onde pode-se observar em cada um deles um painel manual que consiste de 16 teclas que permitem aplicar pressões manualmente na câmara de Bishop-Wesley. 


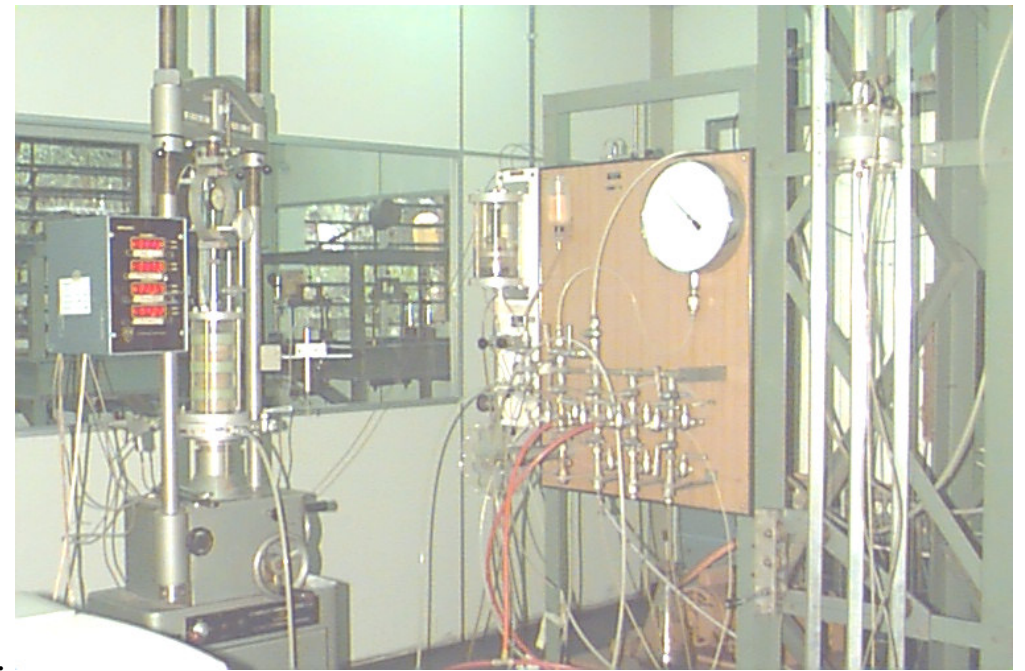

FIGURA 3.9 - Ensaio de compressão triaxial convencional.

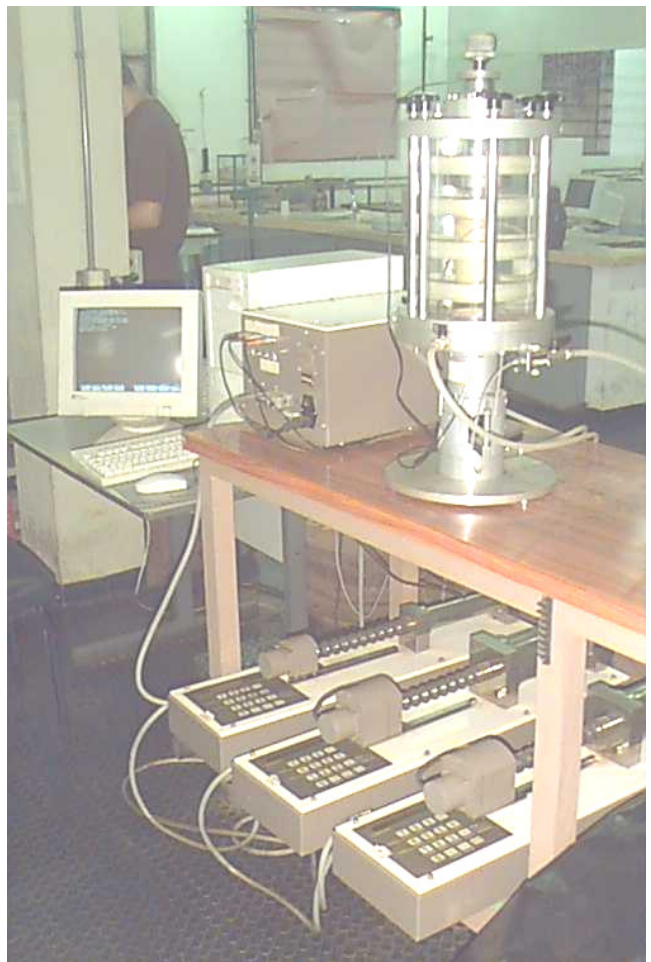

FIGURA 3.10 - Ensaio de compressão triaxial com a câmara de Bishop Wesley (GDS). 


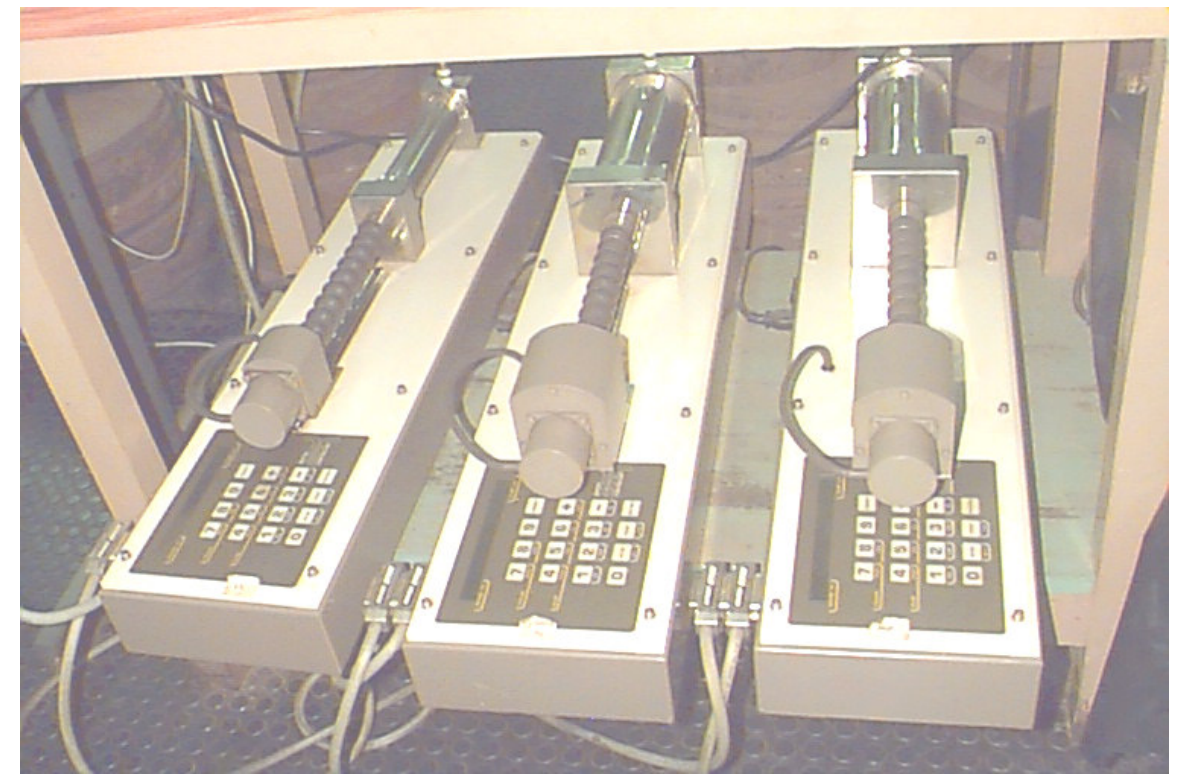

FIGURA 3.11 - Atuadores de pressão/volume utilizados na realização de ensaios do tipo tensão controlada.

Na Figuras 3.12 mostra-se em detalhe a prensa de Bishop Wesley utilizada nos ensaios realizados com o GDS.

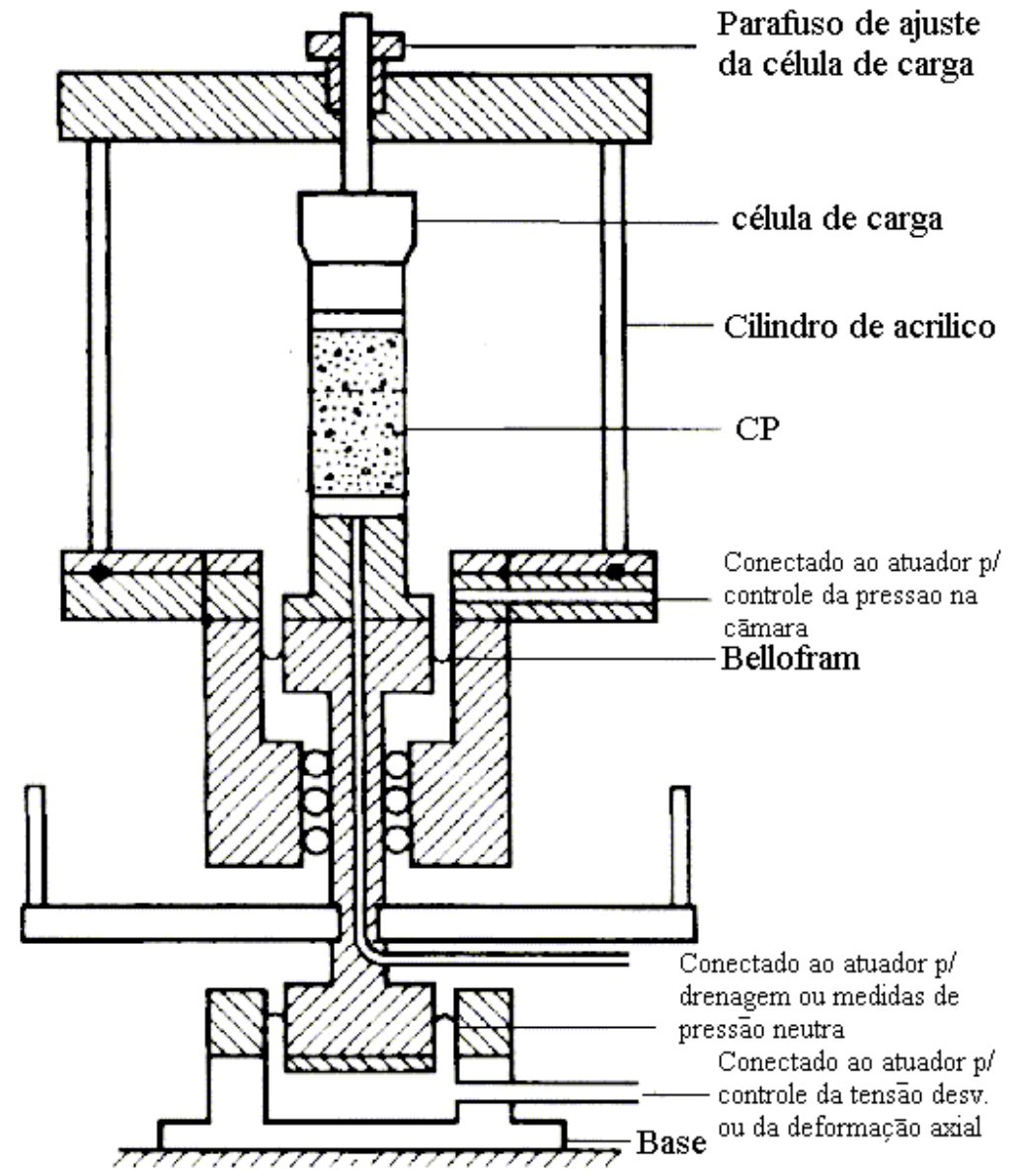

FIGURA 3.12 - Representação esquemática da prensa Bishop Wesley utilizada. 
O software do GDS permitiu armazenar os resultados dos ensaios realizados em formato ASCIL. Posteriormente estes resultados foram tratados em um processador de textos num programa específico elaborado em Quattro Pro for Window, desenvolvido no Laboratório de Geotecnia da EESC/USP.

Detalhes do equipamento GDS podem-se encontrar em Machado (1998).

\subsubsection{ENSAIOS TRIAXIAIS COM CONTROLE DE SUCÇÃO MATRICIAL}

Foram realizados 8 ensaios triaxiais com controle de sucção matricial com a amostra indeformada coletada no local AI1, utilizando-se o equipamento triaxial GDS. Cada ensaio foi realizado mantendo-se constante um determinado valor de sucção matricial $\left(\mathrm{u}_{\mathrm{a}}-\mathrm{u}_{\mathrm{w}}\right)$ e uma tensão de confinamento $\left(\sigma_{3}-u_{\mathrm{a}}\right)$. A velocidade de ensaio em todos os ensaios realizados adotada foi de $0,004 \mathrm{~mm} / \mathrm{min}$.

Para que fosse possível a realização de ensaios triaxiais com controle de sucção matricial, a base da câmara triaxial foi modificada, de modo que seu pedestal foi substituído por outro contendo uma pedra porosa de alto valor de entrada de ar de $500 \mathrm{kPa}$. Os valores de sucção matricial utilizados nos ensaios triaxiais foram de 30, 50, 75, 100, 150 e $300 \mathrm{kPa}$. A conexão com o topo da amostra serviu para aplicação da pressão de ar, sendo a pressão de água aplicada na base contendo o pedestal com a pedra porosa de alto valor de entrada de ar (Figura 3.13).

Para que os ensaios triaxiais fossem realizados em um menor tempo, a sucção matricial desejada foi imposta aos corpos de prova em câmaras separadas, em um total de três câmaras, conectadas a um painel de ar comprimido. O tempo médio de permanência dos corpos de prova para instalação da sucção matricial foi de um mês.

Para que todos os corpos de prova seguissem as mesmas trajetórias de sucção matricial estes eram umedecidos até valores de umidade próximos da umidade de saturação, para que depois a sucção matricial fosse aplicada. Antes de colocar os corpos de prova nas câmaras, estas foram saturadas de modo de retirar bolhas de ar eventualmente aprisionadas e instalava-se aí uma bureta graduada para medida da quantidade de água expulsa do corpo de prova durante o processo de instalação de sucção matricial.

Após a talhagem dos corpos de prova e durante a fase de aplicação da sucção matricial, os corpos de prova eram protegidos por um tubo de PVC, possuindo uma geratriz secionada e um dispositivo montado com braçadeiras de modo a permitir sua instalação e retirada sem causar danos a estrutura da amostra. Um pequeno peso era colocado no topo do 
tubo de PVC de modo a facilitar um bom contato entre a amostra e a pedra porosa de alto valor de entrada de ar, durante a fase de instalação da sucção matricial.

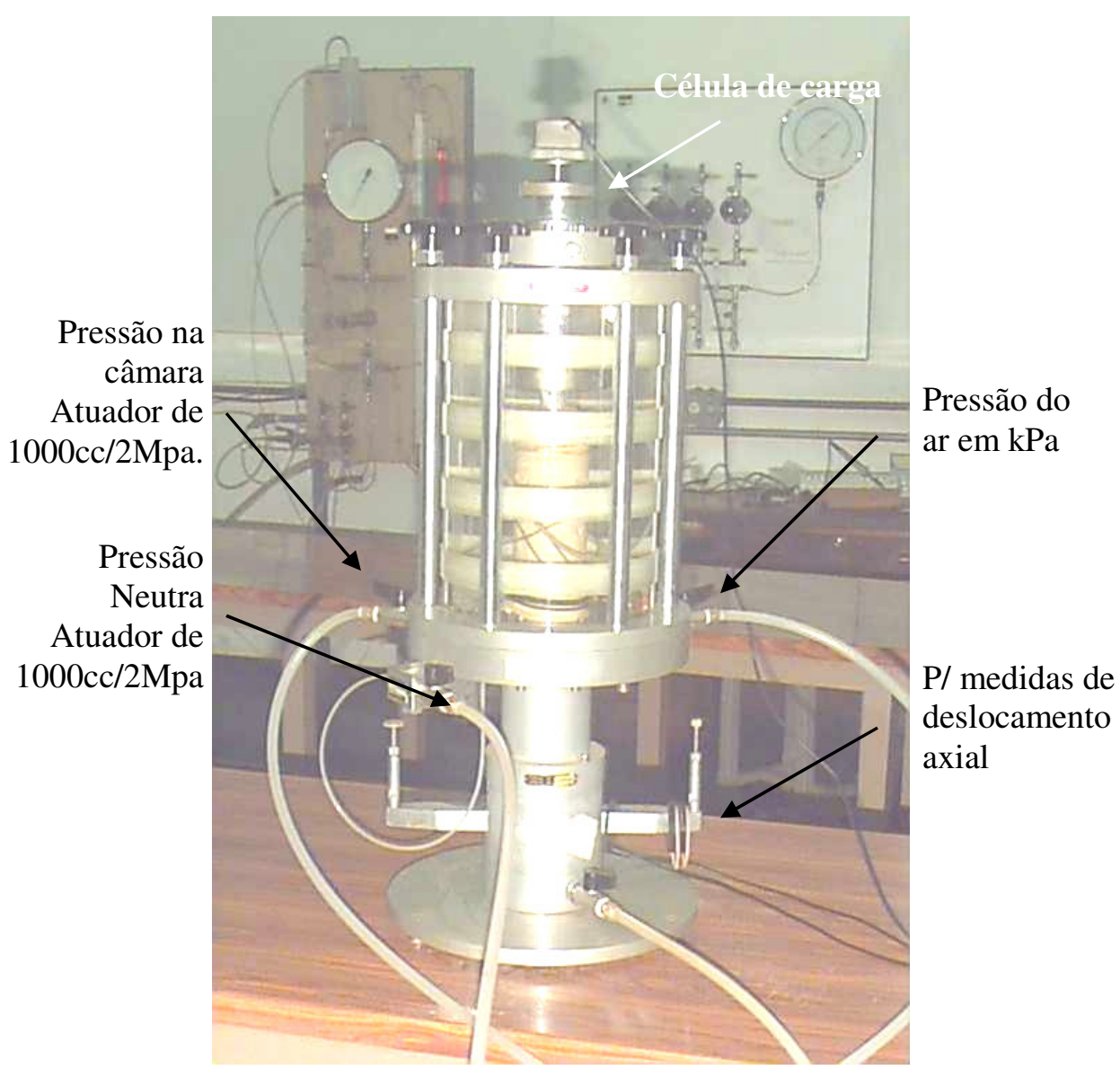

FIGURA 3.13- Prensa triaxial tipo Bishop Wesley utilizada para a realização de ensaios com controle de sucção matricial.

Após o período de instalação da sucção matricial nas amostras, estas eram levadas à câmara triaxial para o adensamento e cisalhamento.

Procurando-se corrigir eventuais variações na sucção matricial instalada no corpo de prova durante a montagem na câmara triaxial, o corpo de prova era deixado na mesma por um período mínimo de dois dias, observando-se a quantidade de água expulsa ou absorvida pelo corpo de prova após a sua instalação. A quantidade de água entrando ou saindo do corpo de prova era medida diretamente no atuador da pressão neutra, que, como foi mencionado, tem um painel manual que permite controlar as pressões e volumes independendo do Software do GDS, sempre que este não esteja em andamento. Uma vez equilibrada a sucção do corpo de prova, este era adensado e cisalhado com o emprego do software do GDS nas condições indicadas na Tabela 3.3. 
Em quase todos os ensaios a água presente na base do corpo de prova estava sujeita a pressões atmosféricas. A Tabela 3.3 apresenta as condições de ensaio para todos os corpos de prova utilizados nos ensaios triaxiais com controle de sucção matricial.

TABELA 3.3- Condições de ensaio dos corpos de prova em ensaios triaxiais com controle de sucção matricial.

\begin{tabular}{cccccc}
\hline No & $\sigma_{3}[\mathrm{kPa}]$ & $\mathrm{u}_{\mathrm{w}}[\mathrm{kPa}]$ & $\mathrm{u}_{\mathrm{a}}[\mathrm{kPa}]$ & $\mathrm{u}_{\mathrm{a}}-\mathrm{u}_{\mathrm{w}}[\mathrm{kPa}]$ & $\sigma_{3}-\mathrm{u}_{\mathrm{a}}[\mathrm{kPa}]$ \\
\hline \hline 1 & 80 & 0 & 30 & 30 & 50 \\
2 & 100 & 0 & 50 & 50 & 50 \\
3 & 200 & 50 & 100 & 50 & 100 \\
4 & 125 & 0 & 75 & 75 & 50 \\
5 & 150 & 0 & 100 & 100 & 50 \\
6 & 240 & 40 & 140 & 100 & 100 \\
7 & 200 & 0 & 150 & 150 & 50 \\
8 & 350 & 0 & 300 & 300 & 50 \\
\hline
\end{tabular}

\subsection{ANÁLISE DE RUPTURA}

$\mathrm{Na}$ análise de ruptura do talude estudado foram considerados os resultados obtidos nos ensaios de campo e laboratório, necessários para modelar o talude e para definir os ábacos de retro-análise, através da utilização de programas.

Os programas utilizados na modelagem e retro-análise foram o SEEP/W e SLOPE/W (Geo-Slope International, 1994, versão 3). O primeiro utilizou-se para estudar o efeito da infiltração da água de chuva na distribuição da pressão neutra no interior do solo, e o segundo para as análises de estabilidade.

No SLOPE/W utilizou-se o método simplificado de Bishop no cálculo do fator de segurança. Neste método a resistência ao cisalhamento está dada pela envoltória de resistência de Fredlund (equação 2.36), que relembrando.

$$
\tau=c^{\prime}+\left(\sigma-u_{\mathrm{a}}\right) \tan \phi^{\prime}+\left(\mathrm{u}_{\mathrm{a}}-\mathrm{u}_{\mathrm{w}}\right) \tan \phi^{\mathrm{b}}
$$

Onde $u_{\mathrm{a}}$ é a pressão de ar, $\mathrm{u}_{\mathrm{w}}$ a pressão de água e $\phi^{\mathrm{b}} \mathrm{o}$ ângulo que define o incremento na resistência ao cisalhamento para o incremento de sucção matricial $\left(\mathrm{u}_{\mathrm{a}}-\mathrm{u}_{\mathrm{w}}\right)$.

Na figura 3.14 mostram-se todas as forças atuando no método simplificado de Bishop, onde as variáveis estão definidas como segue:

W Peso da fatia de largura $b$ e altura $h$. 
$\mathrm{N} \quad$ Força normal total na base da fatia.

$\tau \quad$ Força de cisalhamento mobilizada na base de cada fatia.

E Força normal horizontal entre fatias, aplicada na metade da altura da fatia do lado esquerdo $\mathrm{E}_{\mathrm{L}}$ e do lado direito $\mathrm{E}_{\mathrm{R}}$.

$\mathrm{R}$ Raio da superfície de ruptura circular ou braço de momento associado a força de cisalhamento mobilizada $S_{\mathrm{m}}$.

f Braço da força normal "N" ao centro de momentos ou centro de rotação.

x Distância horizontal do ponto de aplicação do peso de cada fatia ao centro de momentos ou centro de rotação.

a Distância perpendicular da força externa de água "A" ao centro de momentos.

$\alpha \quad$ ângulo entre a tangente ao centro da base de cada fatia e a horizontal.

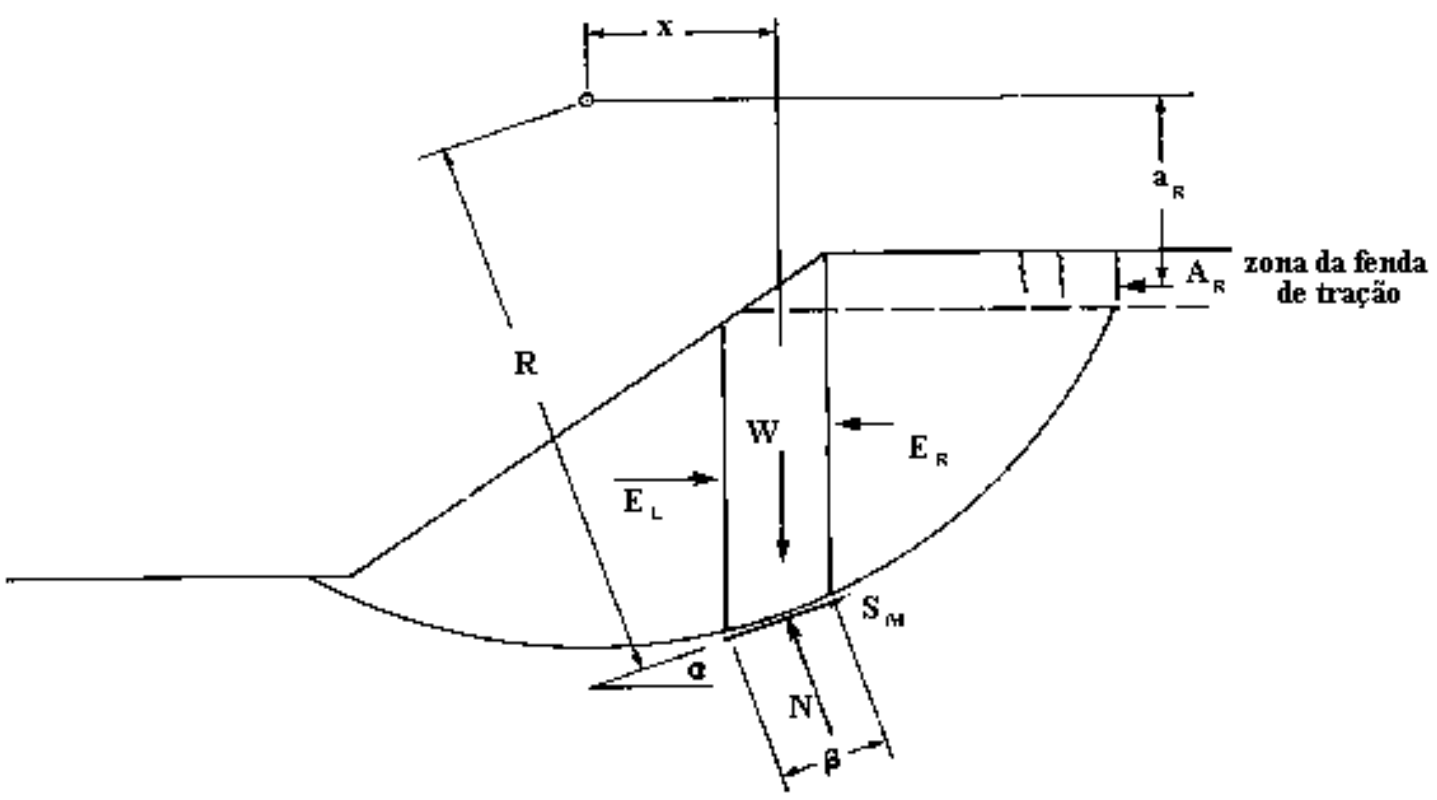

FIGURA 3.14 - Forças atuando numa fatia de uma massa escorregada.

A magnitude da força de cisalhamento mobilizada que satisfaz a condição de equilibro limite está dada pela seguinte equação.

$$
\mathrm{S}_{\mathrm{m}}=\frac{\tau \beta}{\mathrm{FS}}=\frac{\beta\left(\mathrm{c}^{\prime}+\left(\sigma-\mathrm{u}_{\mathrm{a}}\right) \tan \phi^{\prime}+\left(\mathrm{u}_{\mathrm{a}}-\mathrm{u}_{\mathrm{w}}\right) \tan \phi^{\mathrm{b}}\right)}{\mathrm{FS}}
$$

Onde: 


$$
\begin{array}{rlll}
\sigma=\frac{N}{\beta} & = & \text { Tensão normal meia na base de cada fatia. } \\
\text { FS } & = & \text { Fator de segurança. } \\
\beta & = & \text { Largura da fatia (Figura 3.14) }
\end{array}
$$

No entanto, no método simplificado de Bishop só é satisfeita a função do fator de segurança por equilíbrio de momentos respeito a um centro de momentos definido. Dada pela seguinte equação.

$$
\sum \mathrm{Wx}-\sum \mathrm{S}_{\mathrm{m}} \mathrm{R}-\sum \mathrm{Nf} \pm \mathrm{Aa}=0
$$

Levando a equação 3.2 na equação 3.3 e isolando o fator de segurança tem-se.

$$
\mathrm{FS}=\frac{\sum\left(\mathrm{c}^{\prime} \beta \mathrm{R}+\left[\mathrm{N}-\mathrm{u}_{\mathrm{w}} \beta \frac{\tan \phi^{\mathrm{b}}}{\tan \phi^{\prime}}-\mathrm{u}_{\mathrm{a}} \beta\left(1-\frac{\tan \phi^{\mathrm{b}}}{\tan \phi^{\prime}}\right)\right] \mathrm{R} \tan \phi^{\prime}\right)}{\sum \mathrm{Wx}-\sum \mathrm{Nf} \pm \mathrm{Aa}}
$$

A força normal "N" na base de cada fatia da função anterior é obtida por somatória de forças verticais e estará dada pela seguinte equação.

$$
\mathrm{N}=\frac{\mathrm{W}-\frac{\mathrm{c}^{\prime} \beta \sin \alpha}{\mathrm{FS}}+\frac{\mathrm{u}_{\mathrm{a}} \beta \sin \alpha\left(\tan \phi^{\prime}-\tan \phi^{\mathrm{b}}\right)}{\mathrm{FS}}+\frac{\mathrm{u}_{\mathrm{W}} \beta \sin \alpha \tan \phi^{\mathrm{b}}}{\mathrm{FS}}}{\cos \alpha+\frac{\sin \alpha \tan \phi^{\prime}}{\mathrm{FS}}}
$$

A somatória de forças na direção horizontal em cada fatia pode ser escrita.

$$
\left(E_{L}-E_{R}\right)-N \operatorname{sen} \alpha+S_{M} \cos \alpha=0
$$

Levando a equação 3.2 na equação 3.6 e isolando a força normal entre fatias do lado direito de cada fatia tem-se.

$$
\mathrm{E}_{\mathrm{R}}=\mathrm{E}_{\mathrm{L}}+\frac{\mathrm{N}}{\mathrm{FS}}\left(\tan \phi^{\prime} \cos \alpha-\operatorname{sen} \alpha\right)+\frac{\beta \cos \alpha}{\mathrm{FS}}\left(\mathrm{c}^{\prime}-\mathrm{u}_{\mathrm{a}}\left[\tan \phi^{\prime}-\tan \phi^{\mathrm{b}}\right]-\mathrm{u}_{\mathrm{w}} \tan \phi^{\mathrm{b}}\right)
$$


A solução das equações anteriores divide-se em duas etapas. Na primeira etapa, as forças entre fatias são consideradas nulas, portanto a força normal na base de cada fatia será:

$\mathrm{N}=\mathrm{W} \cos \alpha$

Levando este resultado na equação 3.4 determina-se o fator de segurança para a primeira etapa, a mesma que corresponde ao fator de segurança segundo o método de Fellenius.

$\mathrm{Na}$ segunda etapa o fator de segurança pode-se rescrever da seguinte forma:

$$
\mathrm{FS}=\frac{\sum\left(\mathrm{c}^{\prime} \beta-\mathrm{u}_{\mathrm{w}} \beta \tan \phi^{\mathrm{b}}-\mathrm{u}_{\mathrm{a}} \beta\left(\tan \phi^{\prime}-\tan \phi^{\mathrm{b}}\right)\right) \mathrm{R}+\sum \mathrm{NR} \tan \phi^{\prime}}{\sum \mathrm{Wx}-\sum \mathrm{Nf} \pm \mathrm{Aa}}
$$

Onde $\mathrm{N}$ é a força normal na base da fatia obtida utilizando-se o fator de segurança calculada na etapa anterior.

Com este valor determina-se um novo valor de força normal (equação 3.5), fator de segurança (equação 3.4) e forças normais entre fatias (equação 3.7). Procede-se seguidamente a novas iterações até obter a convergência das equações não lineares.

Observa-se nas equações 3.4 e 3.9 que quando o centro de momentos não coincide com o centro da superfície de ruptura $(f \neq 0)$ o fator de segurança obtido será maior que quando estes coincidem ( $\mathrm{f}=0)$ e portanto não será um fator de segurança crítico. Segundo esta observação na análise de ruptura do presente trabalho os centros dos círculos de ruptura coincidem com os centros de momentos. 


\section{RESULTADOS OBTIDOS}

\subsection{RECONHECIMENTO GEOTÉCNICO}

A Figura 4.1 mostra uma seção do talude em análise com os valores de resistência a penetração "N" do "Standard Penetration Test" medidos em duas sondagens de simples reconhecimento. De acordo com estas sondagens, observa-se um perfil de solo praticamente homogêneo, composto de uma areia argilo-siltosa marrom com compacidade variando de fofa a média. Verifica-se também, que o nível de água não foi atingido até os $20 \mathrm{~m}$, que foi o limite da sondagem. No anexo A podem-se observar as folhas de sondagem utilizadas para as duas sondagens realizadas.

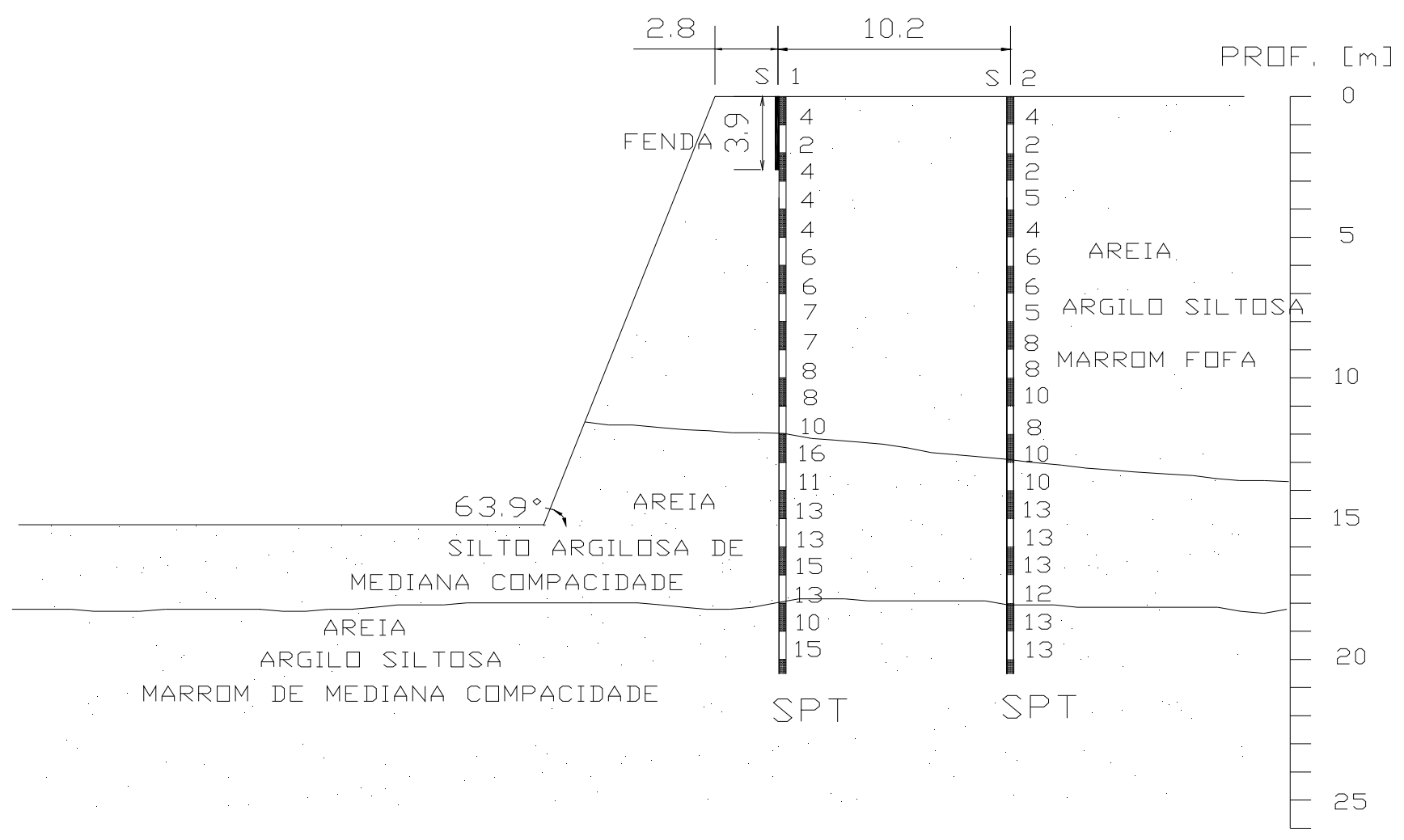

FIGURA 4.1 - Perfil provável do solo no talude. 
A topografia mostrou que o talude original tinha uma altura de 15,2m, uma inclinação de $63,9^{\circ}$ e uma fenda com cerca de $2,6 \mathrm{~m}$ de profundidade, posicionada a $2,8 \mathrm{~m}$ da crista do talude.

Na Figura 4.2 apresentam-se os limites de consistência, as umidades e os graus de saturação, ao longo da profundidade, medidas por ocasião da realização das sondagens realizadas nos dias 09 e 10 de Agosto de 1999. Pode-se verificar que a umidade varia lentamente com a profundidade e que os limites de consistência permanecem quase constantes. Na sondagem S2 não foram feitos estes ensaios, pois a umidade durante a tradagem foi modificada. No entanto, a variação no SPT devido a alteração desta umidade apresentou-se semelhante a sondagem S1, possivelmente porque a percolação da água no solo foi muito lenta, não sendo possível atingir a saturação do solo.

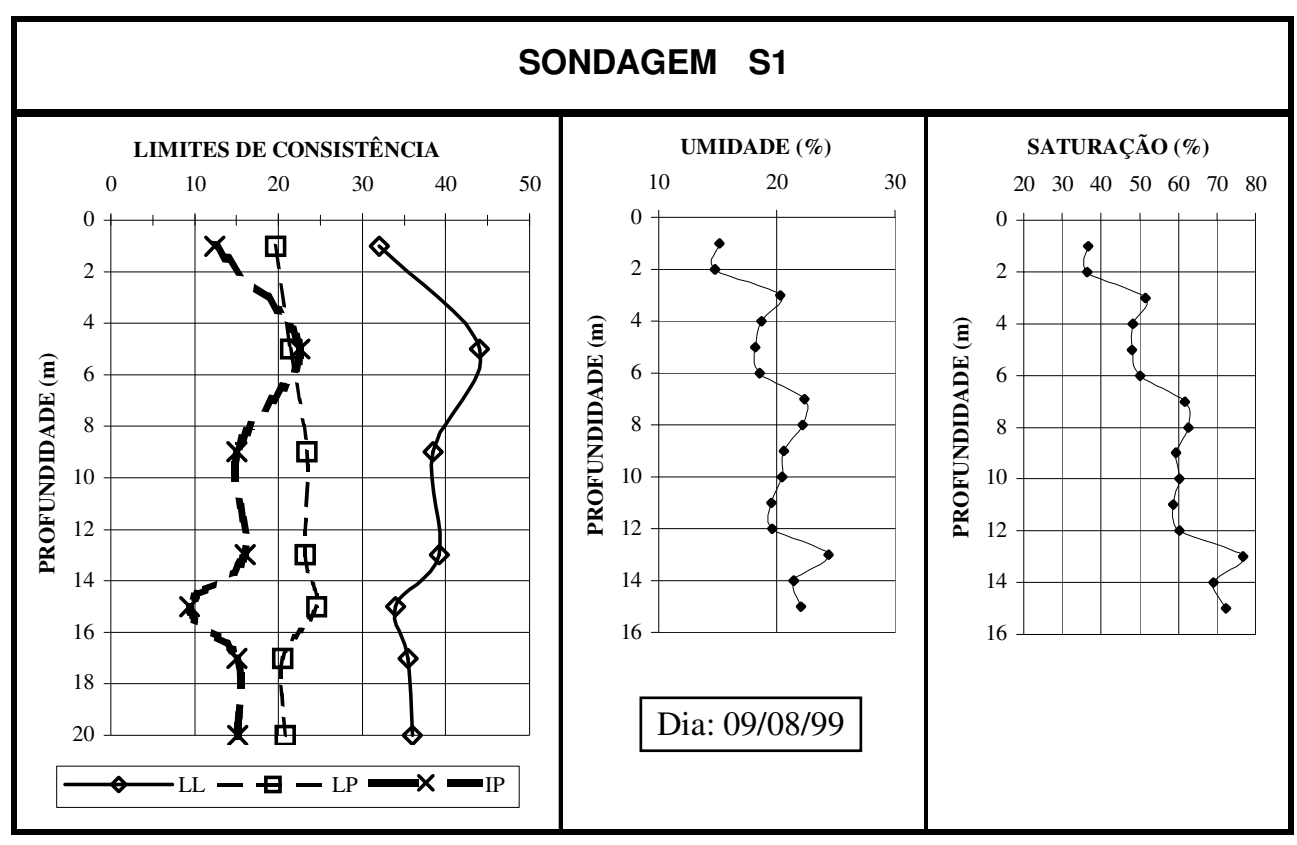

FIGURA 4.2 - Limites de consistência e umidade da sondagem S1.

\subsection{ENSAIOS DE CARACTERIZAÇÃO}

Na tabela 4.1 são mostrados os índices físicos médios dos blocos indeformados coletados nos locais de amostragem do topo (AI1 e AI3) e da base (AI2).

TABELA 4.1 - Ensaios de caracterização dos blocos indeformados coletados do topo e da base do talude.

\begin{tabular}{|c|c|c|c|c|c|c|}
\hline & $w(\%)$ & $\rho\left(\mathrm{g} / \mathrm{cm}^{3}\right)$ & $\rho_{\mathrm{s}}\left(\mathrm{g} / \mathrm{cm}^{3}\right)$ & $\rho_{\mathrm{d}}\left(\mathrm{g} / \mathrm{cm}^{3}\right)$ & $\mathrm{e}$ & $\mathrm{Sr}(\%)$ \\
\hline Al1(topo) & 21,5 & 1,6 & 2,9 & 1,32 & 1,20 & 52,1 \\
\hline Al2(base) & 16,9 & 1,8 & 2,9 & 1,54 & 0,88 & 55,5 \\
\hline Al3(topo) & 21,0 & 1,6 & 2,9 & 1,32 & 1,20 & 50,9 \\
\hline
\end{tabular}




\subsection{CURVA DE RETENÇÃO DA ÁGUA DO SOLO}

Foi determinada a curva de retenção por secagem das amostras indeformadas AI1, AI2 e AI3, cujos resultados são mostrados nas Figuras 4.3, 4.4 e 4.5, onde PF é o resultado obtido com o papel filtro e CP com a câmara de pressão. Em conjunto com os pontos experimentais estão as curvas ajustadas segundo a equação 2.6 (Van Genutchen, 1980), podendo-se obter os seguintes parâmetros da referida equação (Tabela 4.2).

TABELA 4.2 - Parâmetros da equação de Van Genutchen (1980).

\begin{tabular}{|c|c|c|c|c|c|}
\hline & $\boldsymbol{\alpha}(\mathbf{1} / \mathbf{c m})$ & $\mathbf{m}$ & $\mathbf{n}$ & $\mathbf{w}_{\mathbf{r}}$ & $\mathbf{w}_{\mathbf{s}}$ \\
\hline \hline $\mathrm{AI} 1$ & 0,08 & 0,33 & 1,49 & 0,13 & 0,40 \\
\hline $\mathrm{AI} 2$ & 0,06 & 0,23 & 1,29 & 0,13 & 0,30 \\
\hline $\mathrm{AI} 3$ & 0,16 & 0,28 & 1,38 & 0,11 & 0,40 \\
\hline
\end{tabular}

Nas Tabelas do anexo B, apresentam-se os resultados de cada corpo de prova utilizados no ensaio com papel filtro, considerando-se neles o $\rho_{\mathrm{d}}$ do ítem 4.2, constante para todos os corpos de prova de cada local de amostragem respectivamente. No Anexo C mostram-se os cálculos e resultados obtidos com os corpos de prova utilizados na câmara de pressão.

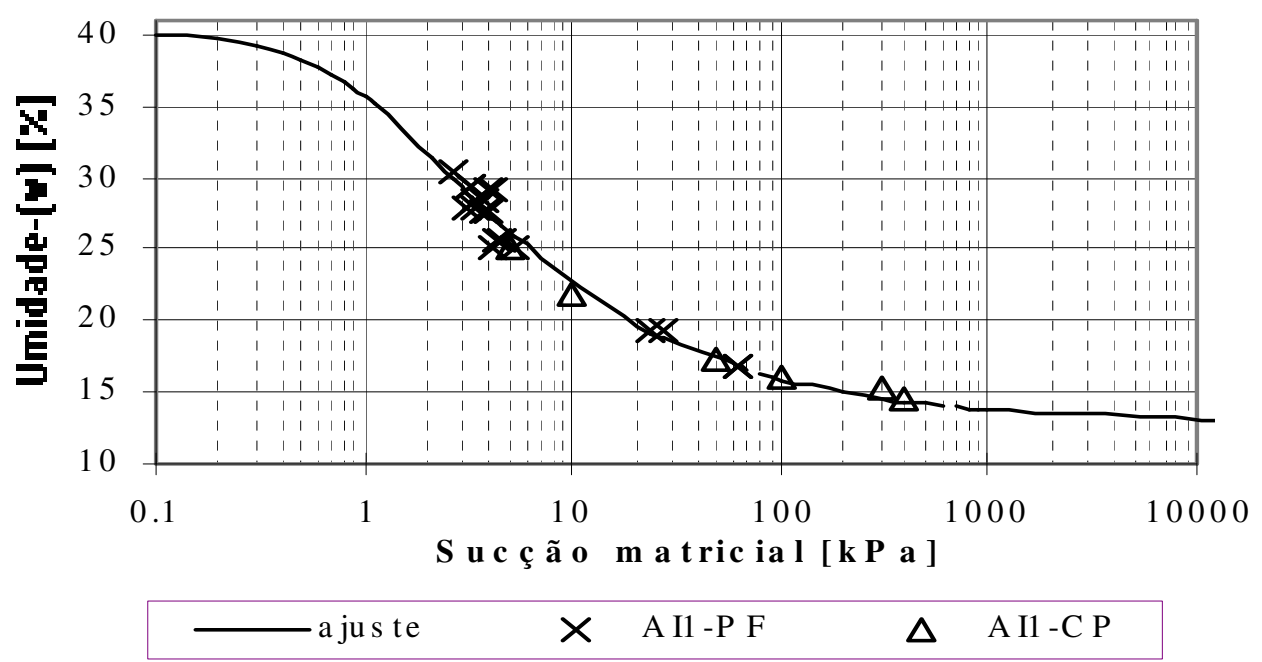

FIGURA 4.3-Curva de retenção local de amostragem AI1. 


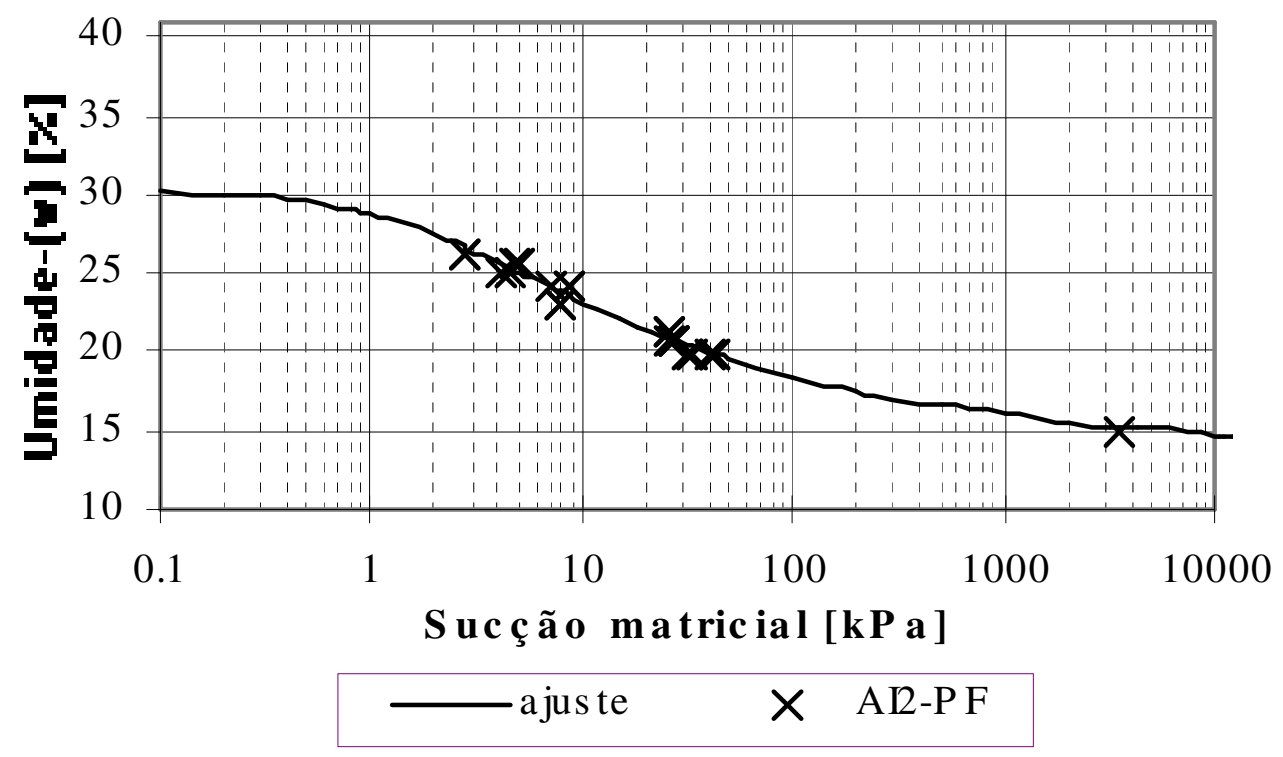

FIGURA 4.4 - Curva de retenção local de amostragem AI2.

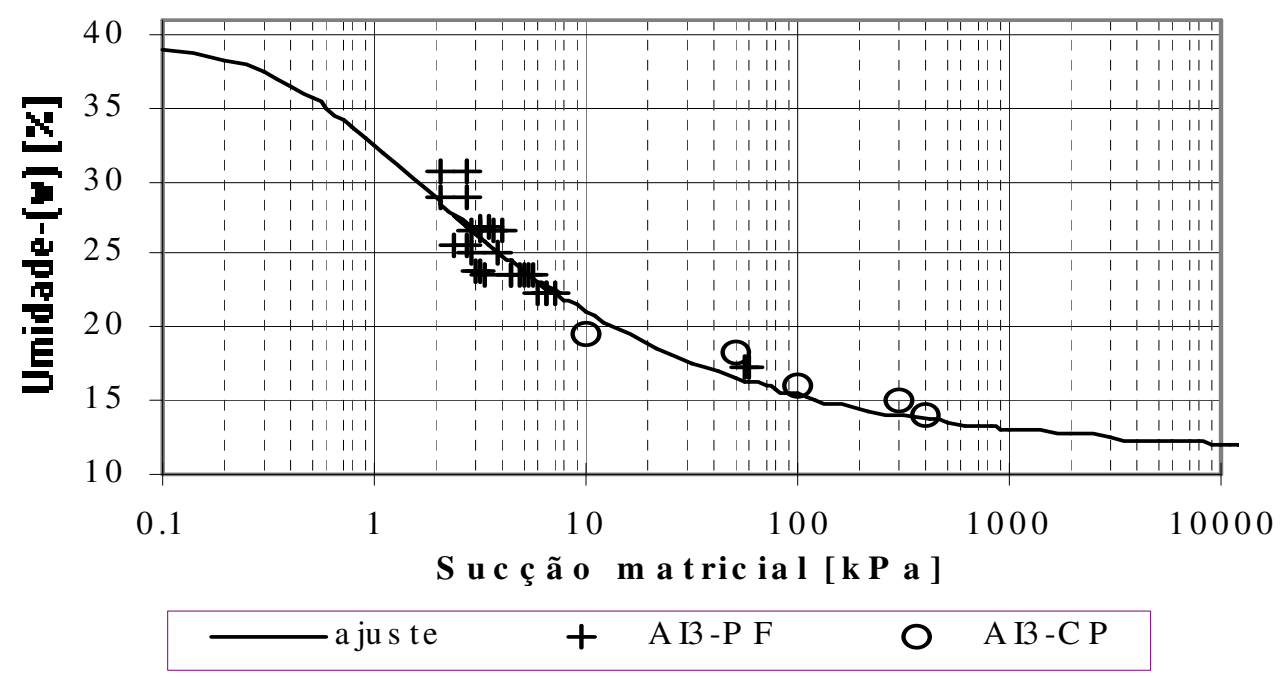

FIGURA 4.5 - Curva de retenção local de amostragem AI3.

Pode-se observar que as curvas de retenção obtidas no topo do talude (AI1 e AI3), são próximas uma da outra; e a curva AI2, obtida na base do talude, apresenta uma menor umidade de saturação $\phi$ 's, respeito as amostras do topo. Observa-se, também, que os resultados obtidos com a câmara de pressão foram próximos a curva de retenção obtida com a formula de Van Genutchen (1980).

Das três curvas de retenção obtidas, a curva de retenção do local de amostragem AI1 foi a utilizada na modelagem e retro-análise apresentadas no capítulo 5, pois a amostragem encontrava-se no eixo da zona escorregada. Esta equação pode ser escrita como: 


$$
\mathrm{w}[\%]=\left(0,13+\frac{(0,40-0,13)}{\left[1+(0,08 * \psi)^{1,489}\right]^{0,328}}\right) * 100
$$

Onde $\psi$ é a sucção em $\mathrm{cm}$.

\subsection{MEDIDA DE SUCÇÃO MATRICIAL NO CAMPO}

Na Figura 4.6 apresentam-se as leituras de sucção matricial dos tensiômetros, encontradas em campo e as leituras de precipitação diária, obtidas da Estação Metereológica Crhrea, localizada em Itirapina-SP, represa de Broa.

Pode-se verificar que a sucção matricial máxima registrada foi próxima de $60 \mathrm{kPa}$ e que a precipitação incrementou-se na época de verão, reduzindo-se a sucção matricial.
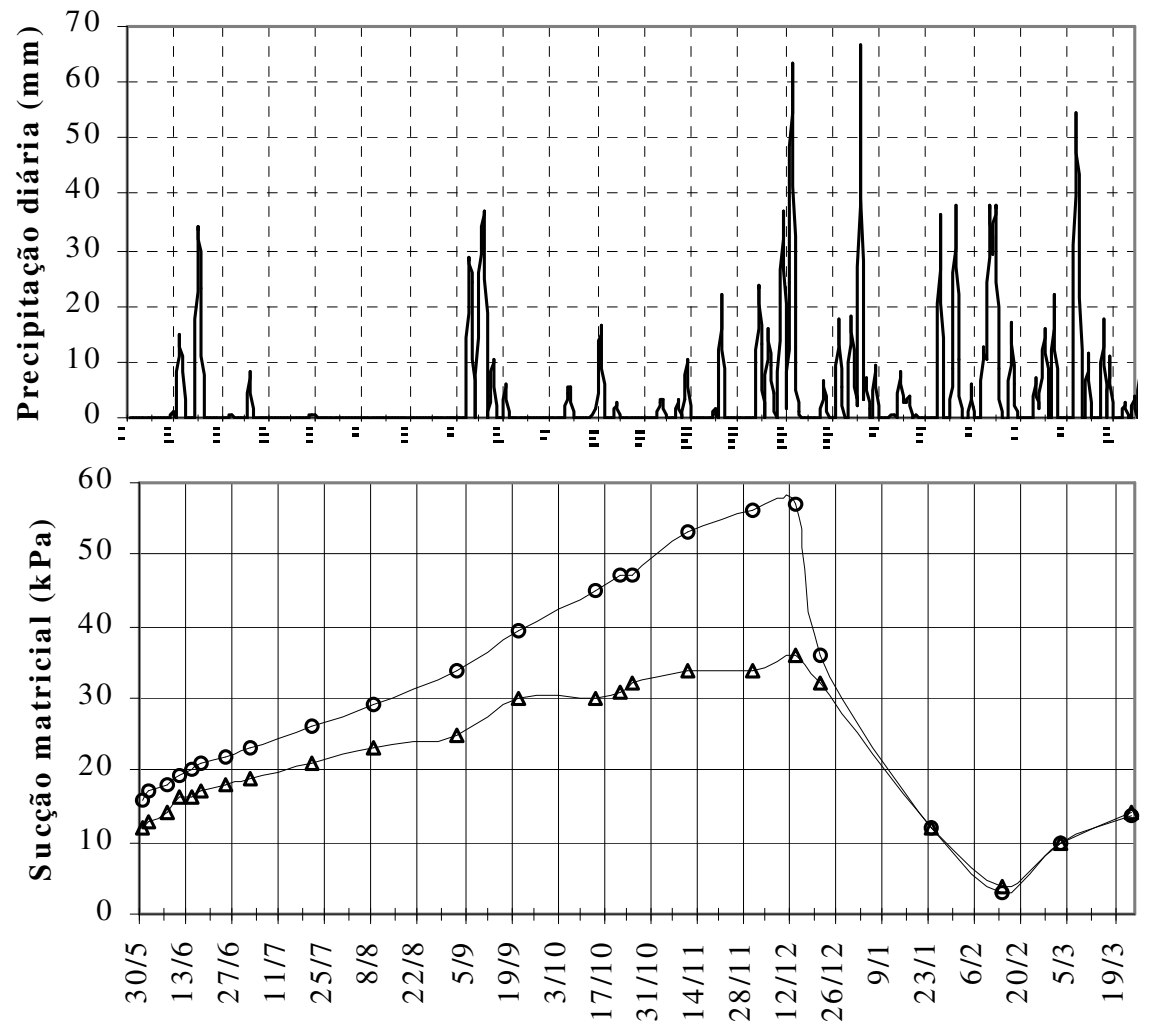

Tem po (dias)

- $2,36 \mathrm{~m}$ prof. do topo $\_3,31 \mathrm{~m}$ prof. do topo

FIGURA 4.6 - Leituras de sucção matricial nos tensiômetros 1 e 2, período 1999/2000.

Além das leituras feitas no campo, determinou-se a sucção matricial em dois pontos próximos aos tensiômetros, utilizando-se a curva de retenção do local de amostragem AI1, 
obtida do ensaio de papel filtro, com o propósito de comparar os resultados obtidos pelos dois métodos (Tabela 4.3).

TABELA 4.3 - Quadro comparativo da sucção medida por tensiômetro e papel filtro.

\begin{tabular}{|c|c|c|c|c|}
\hline \multirow{2}{*}{ día } & \multicolumn{2}{|c|}{ Tensiômetros $(\mathrm{kPa})$} & \multicolumn{2}{c|}{ Papel filtro $(\mathrm{kPa})$} \\
\cline { 2 - 5 } & $\mathrm{T} 1$ & $\mathrm{~T} 2$ & Próximo-T1 & Próximo-T2 \\
\hline 22/Out/99 & 47 & 31 & 54 & 38 \\
\hline 24/Mar/00 & 13,8 & 14 & 20 & 20 \\
\hline
\end{tabular}

Pode-se observar na Tabela 4.3, que os resultados obtidos da curva de retenção AI1, são um tanto maiores que os resultados proporcionados pelos tensiômetros, devido possivelmente a várias razões como: tipo de papel filtro utilizado, erros acidentais durante o ensaio, perda ou ganho de umidade do papel filtro durante a pesagem, entre outros.

O resultado e localização da sucção matricial máxima, encontrada pelos tensiômetros, foi utilizado como condição de fronteira na modelagem e retro-análise do presente trabalho.

\subsection{CONDUTIVIDADE HIDRÁULICA SATURADA}

Na tabela 4.4, mostra-se as características do corpo de prova utilizada no ensaio de permeabilidade com carga variável no laboratório, extraída do local de amostragem AI1, mostra-se também e resultado obtido.

TABELA 4.4 - Características do corpo de prova do ensaio de permeabilidade.

\begin{tabular}{|c|c|c|c|c|c|c|}
\hline$\rho\left(\mathrm{g} / \mathrm{cm}^{3}\right)$ & $\rho_{\mathrm{s}}\left(\mathrm{g} / \mathrm{cm}^{3}\right)$ & $\mathrm{w}(\%)$ & $\rho_{\mathrm{d}}\left(\mathrm{g} / \mathrm{cm}^{3}\right)$ & $\mathrm{e}$ & $\mathrm{S}(\%)$ & $\mathrm{Ks}_{\mathrm{lab}}(\mathrm{cm} / \mathrm{s})$ \\
\hline 1,57 & 2,90 & 21,2 & 1,30 & 1,24 & 49,7 & $4,4 \mathrm{E}-04$ \\
\hline
\end{tabular}

\subsection{CURVA DE CONDUTIVIDADE HIDRÁULICA NÃO SATURADA}

A partir dos resultados dos ensaios de campo e da proposta de Gardner (1958), calcularam-se as funções condutividade hidráulica não saturada. A Tabela 4.5 apresenta os parâmetros $K_{\mathrm{s}}$, $\phi_{\mathrm{gm}} \mathrm{e} \alpha$, da mencionada função, obtidos para os locais de amostragem AI1 e $\mathrm{AI} 3$, do topo, segundo a metodologia apresentada no capítulo anterior. 
TABELA 4.5 - Parâmetros da condutividade hidráulica não saturada do topo do talude.

\begin{tabular}{|c|c|c|c|c|c|c|c|c|c|c|}
\hline & $\mathrm{a}[\mathrm{cm}]$ & $\mathrm{H} 1[\mathrm{~cm}]$ & $\mathrm{H} 2[\mathrm{~cm}]$ & $\mathrm{C} 1$ & $\mathrm{C} 2$ & $\mathrm{Q} 1\left[\mathrm{~cm}^{3} / \mathrm{s}\right]$ & $\mathrm{Q} 2\left[\mathrm{~cm}^{3} / \mathrm{s}\right]$ & $\mathrm{K}_{\mathrm{s}}[\mathrm{cm} / \mathrm{s}]$ & $\phi_{\mathrm{gm}}\left[\mathrm{cm}^{2} / \mathrm{s}\right]$ & $\alpha\left[\mathrm{cm}^{-1}\right]$ \\
\hline $\mathrm{AI} 1$ & 3 & 5 & 10 & 0,85 & 1,3 & 0,608 & 0,831 & $1,5 \mathrm{E}-04$ & 0,015 & 0,010 \\
\hline $\mathrm{AI} 3$ & 3 & 5 & 10 & 0,85 & 1,3 & 0,389 & 0,555 & $1,6 \mathrm{E}-04$ & 0,009 & 0,018 \\
\hline
\end{tabular}

Ainda, pode-se verificar na Tabela 4.4, que a condutividade hidráulica saturada média obtida em campo $\left(\mathrm{K}_{\mathrm{s}}=1,6 \mathrm{E}-04 \mathrm{~cm} / \mathrm{s}\right)$, é um valor muito próximo ao obtido em laboratório $\left(\mathrm{Ks}_{\mathrm{lab}}=4,4 \mathrm{E}-04 \mathrm{~cm} / \mathrm{s}\right)$, e muito próximo também, ao obtido segundo as equações proporcionadas no manual do permeâmetro Guelph, mostradas no Anexo $\mathrm{D},\left(\mathrm{K}_{\mathrm{s}}[\mathrm{AI} 1]=1,22 \mathrm{E}\right.$ $04 \mathrm{~cm} / \mathrm{s}$ e $\left.\mathrm{K}_{\mathrm{s}}[\mathrm{AI} 3]=1,76 \mathrm{E}-04 \mathrm{~cm} / \mathrm{s}\right)$.

Na Figura 4.7 apresenta-se a curva de condutividade hidráulica média não saturada obtida para os locais de amostragem do topo, AI1 e AI3, onde considera-se os resultados médios dos parâmetros $\mathrm{K}_{\mathrm{s}}, \phi_{\mathrm{gm}} \mathrm{e} \alpha$ (Tabela 4.5). Foi considerada a média dos parâmetros encontrados nos locais de amostragem, pois às funções de condutividade hidráulica não saturada deles resultaram muito próximas uma da outra.

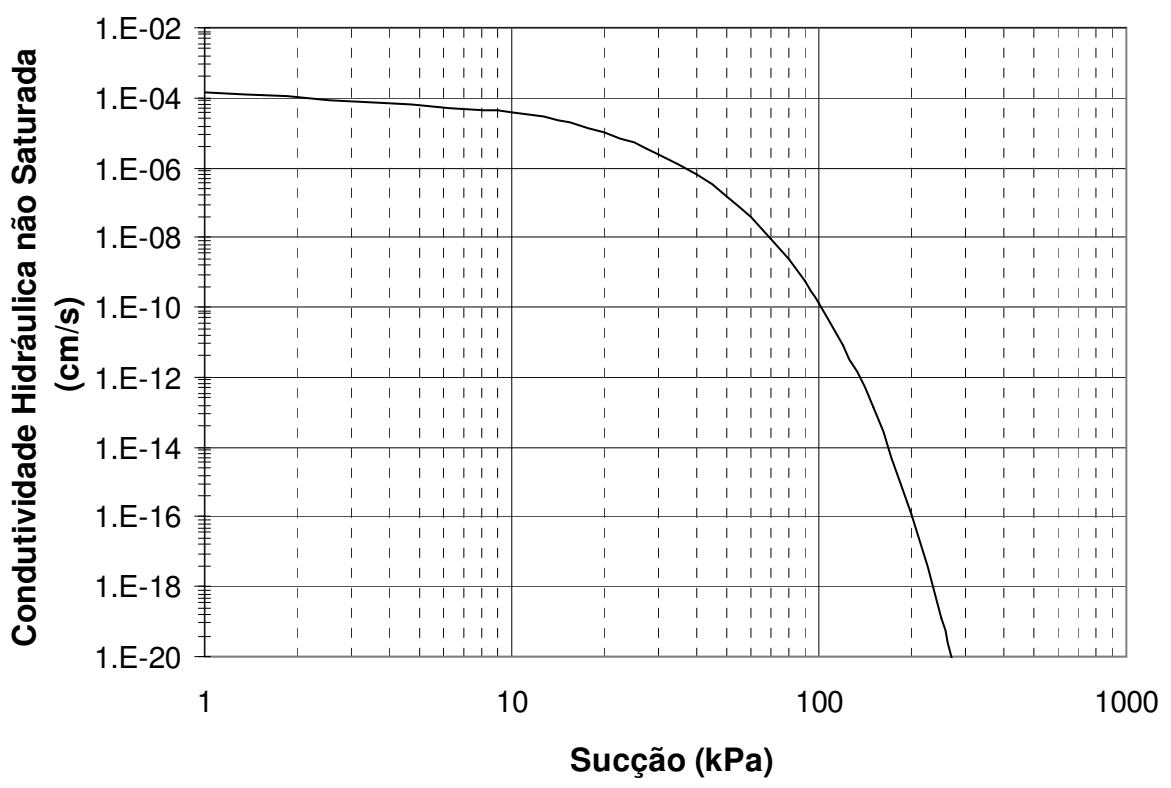

FIGURA 4.7 - Função Condutividade Hidráulica não Saturada ( $\alpha=0.014)$.

A função condutividade hidráulica não saturada utilizada na modelagem e retroanálise, segundo equação 2.19, ficará expressa como:

$$
\mathrm{K}(\psi)[\mathrm{m} / \mathrm{s}]=1,6 \mathrm{E}-06 * \mathrm{e}^{0,14 \psi[\mathrm{kPa}]}
$$




\subsection{ENSAIOS DE COMPRESSÃO TRIAXIAL}

\subsubsection{ENSAIOS TRIAXIAIS CONVENCIONAIS.}

\section{- Corpos de prova saturados por contrapressão.}

Nas Figuras 4.8 e 4.9 mostram-se as curvas tensão - deformação e variação volumétrica - deformação obtidas nos ensaios de compressão triaxial drenados (CD), saturados por contrapressão, de corpos de prova do topo e base respectivamente.
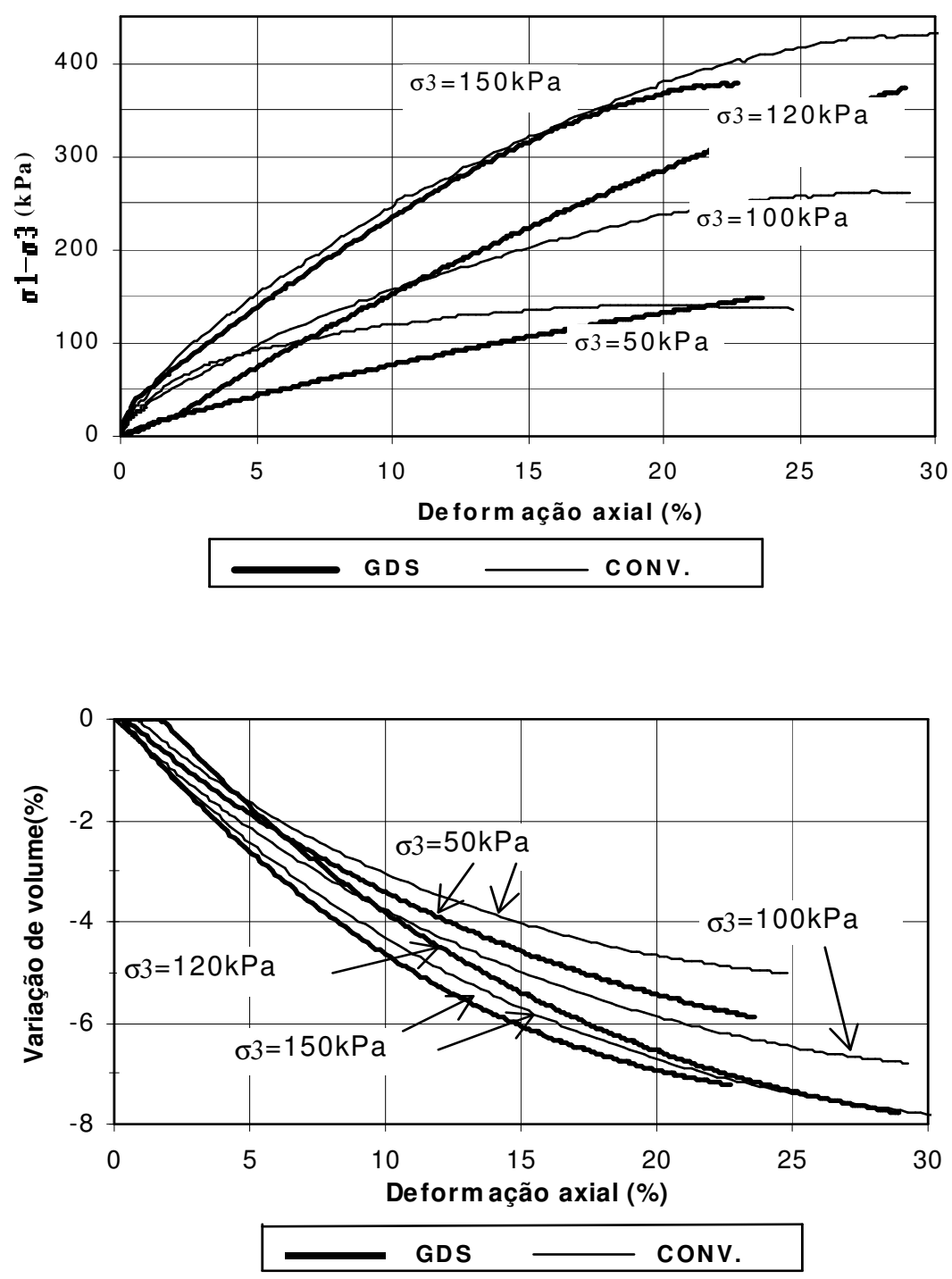

FIGURA 4.8 - Curvas tensão - deformação e variação volumétrica - deformação (topo-AI1). 

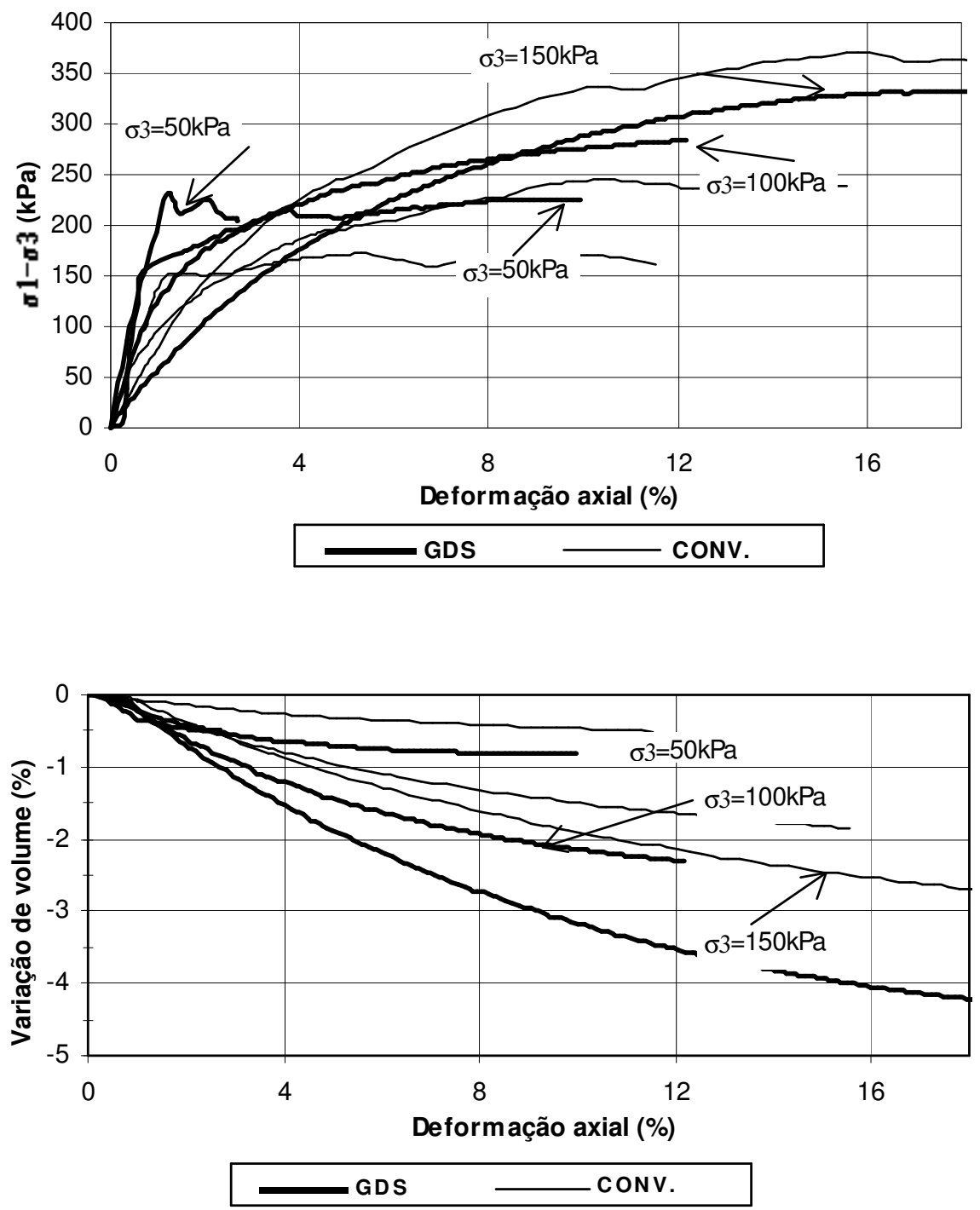

FIGURA 4.9 - Curvas tensão - deformação e variação volumétrica - deformação (base-AI2).

A partir desses resultados, definiram-se as envoltórias de resistência (equação 2.34), considerando-se as tensões máximas. A Figura 4.10 mostra as envoltórias de resistência obtidas para as amostras do topo e da base, que têm por equações, respectivamente:

$$
\begin{aligned}
& \tau=\sigma^{\prime} . \operatorname{tg} 35^{\circ} \mathrm{kPa} \quad \text { (topo) } \\
& \tau=37,2+\sigma^{\prime} \cdot \operatorname{tg} 25,7^{\circ} \mathrm{kPa} \quad \text { (base) }
\end{aligned}
$$


a) Topo

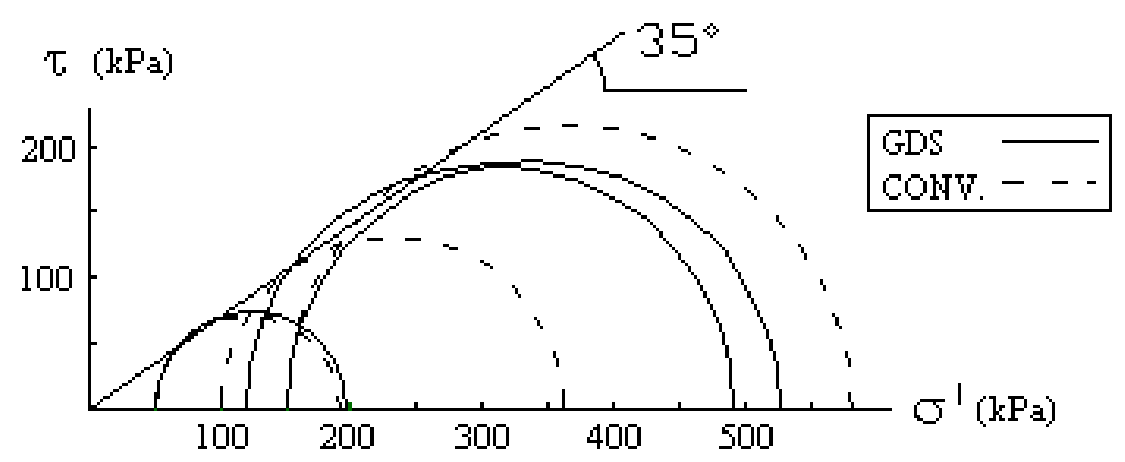

b) Base

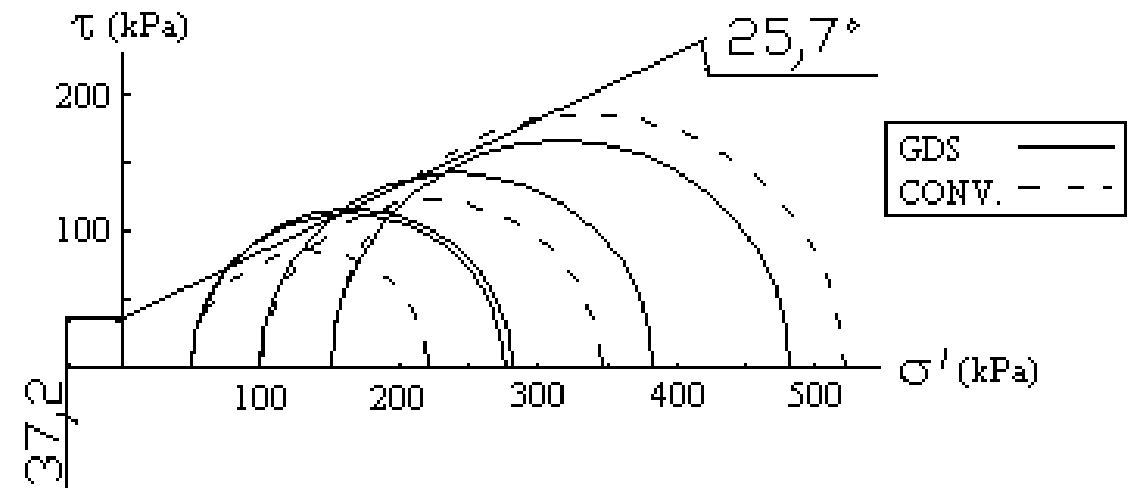

FIGURA 4.10 - Envoltórias de resistência dos ensaios CD para as amostras do topo e base respectivamente.

Os círculos em linhas contínuas da Figura 4.9 provêm dos ensaios triaxiais realizados no equipamento GDS e as linhas pontilhadas dos ensaios triaxiais convencionais. Pode-se observar dos resultados obtidos que os dois equipamentos de compressão triaxial (GDS e convencional) apresentaram envoltórias de resistência próximas, sendo o GDS muito mais simples de manipular.

\section{- Corpos de prova na umidade natural}

Na Figura 4.11 mostram-se as curvas tensão - deformação, obtidas nos ensaios de compressão triaxial não drenados (UU), em corpos de prova na umidade natural. 
a) Topo

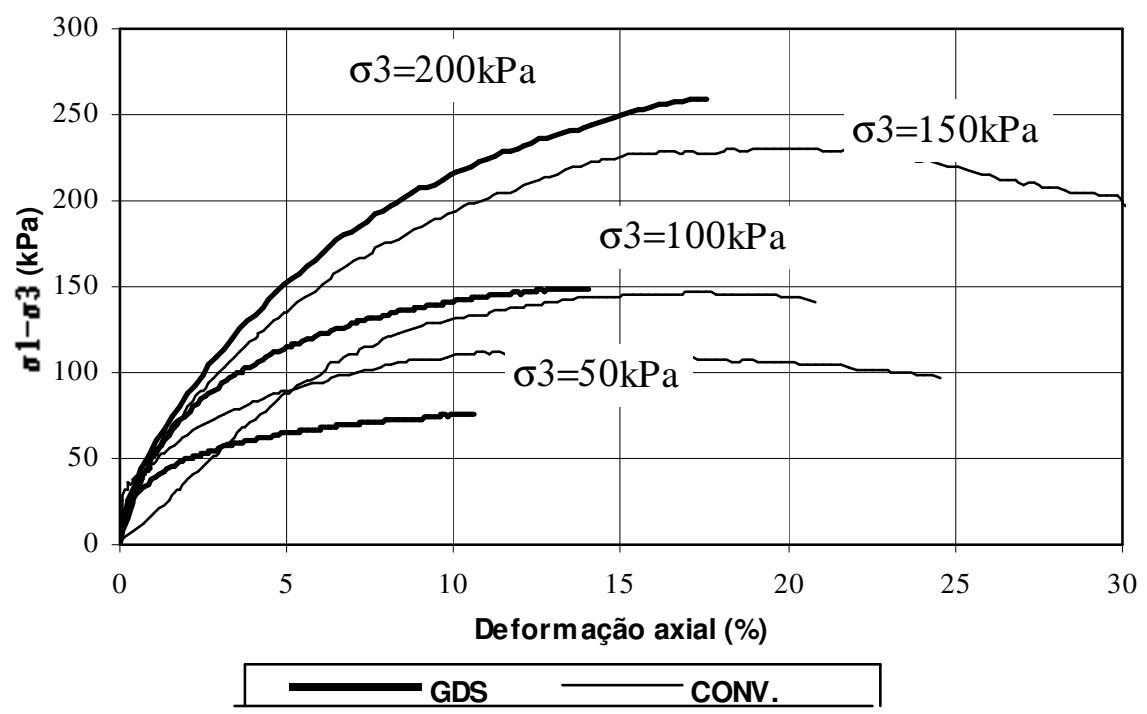

b) Base

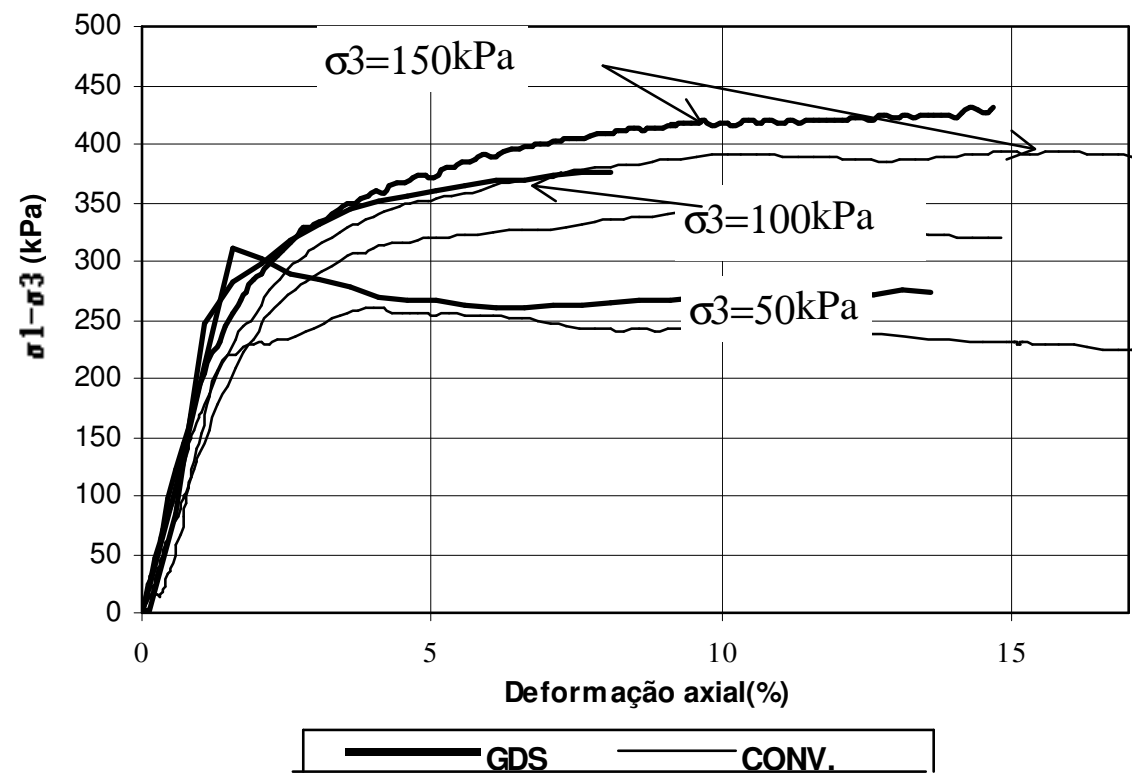

FIGURA 4.11 - Curvas tensão - deformação do ensaio não drenados (UU) na umidade natural.

A partir desses resultados, definiram-se as envoltórias de resistência não drenada (equação 2.34). A Figura 4.12 mostra a envoltória obtida para as amostras do topo e da base, que têm por equações, respectivamente:

$$
\begin{aligned}
& \tau=11+\sigma . \operatorname{tg} 22,3^{\circ} \mathrm{kPa} \quad \text { (topo) } \\
& \tau=68,9+\sigma . \operatorname{tg} 24,1^{\circ} \mathrm{kPa} \quad \text { (base) }
\end{aligned}
$$


a) Topo

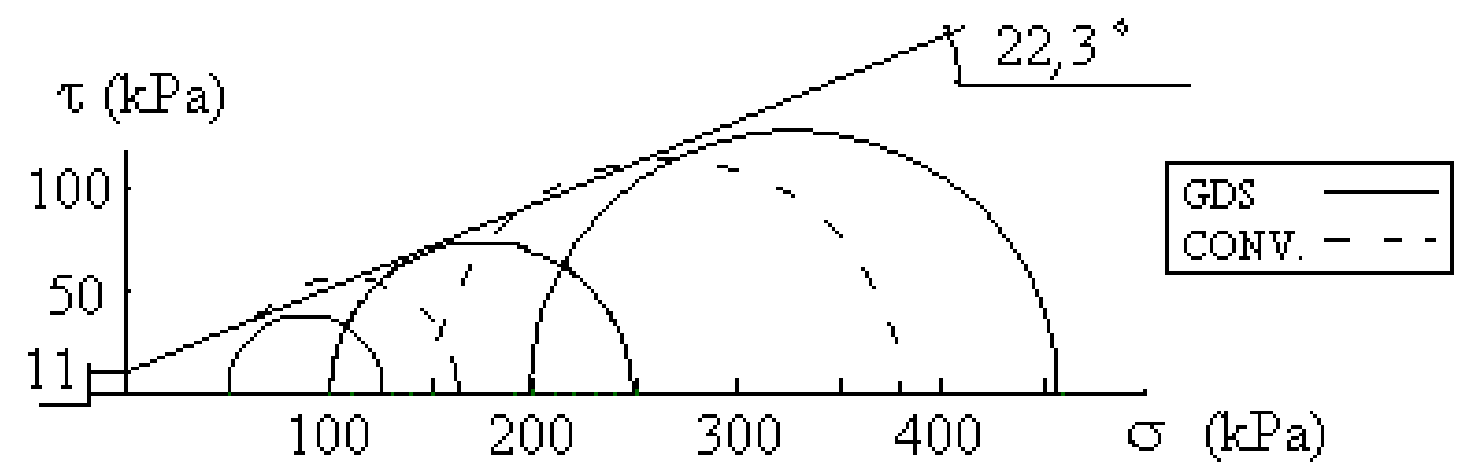

b) Base

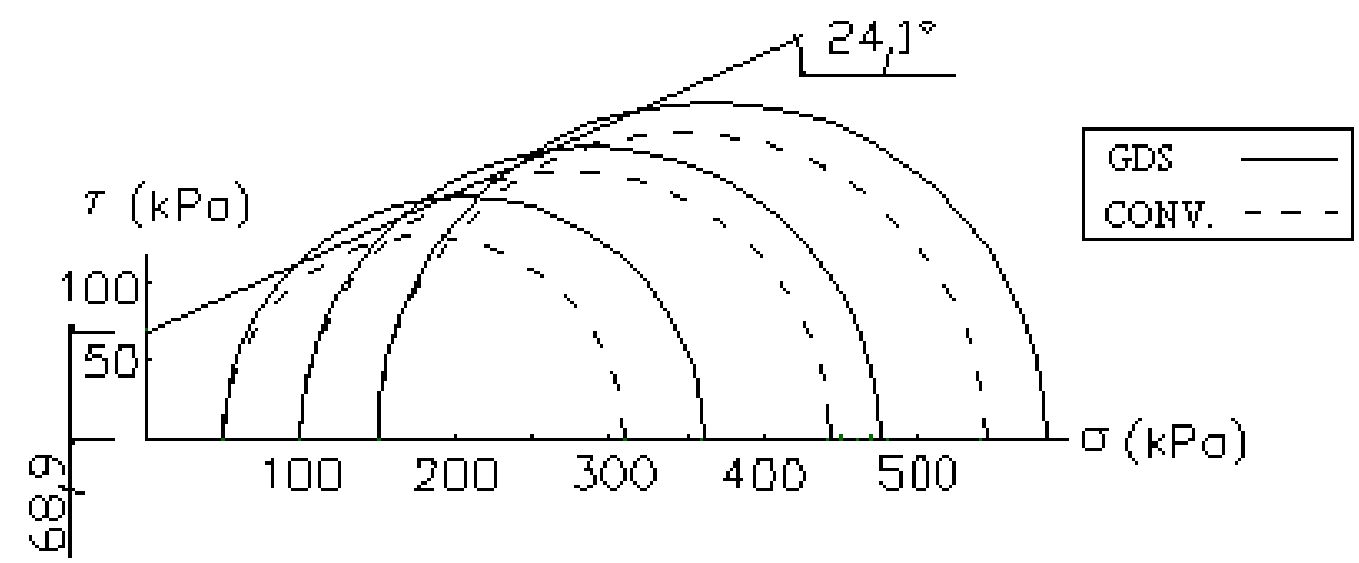

FIGURA 4.12- Envoltórias de resistência dos ensaios UU para amostras do topo e base respectivamente.

As linhas contínuas da Figura 4.12 provêm dos ensaios triaxiais realizados no equipamento GDS e as linhas pontilhadas dos ensaios triaxiais convencionais. Novamente, pode-se comprovar que os resultados obtidos com ambos equipamentos apresentaram envoltórias de resistência próximas. Observa-se, também, que para baixos valores de confinamento o GDS apresenta maior precisão nas medidas de deformação axial.

No Anexo E, apresentam-se as características dos corpos de prova utilizados tanto nos ensaios $\mathrm{CD}$, drenados por contrapressão, como nos ensaios UU, não drenados, em umidade natural. 


\subsubsection{ENSAIOS TRIAXIAIS COM CONTROLE DE SUCÇÃO MATRICIAL}

A Figura 4.13 mostra os diagramas tensão - deformação dos ensaios triaxiais com controle de sucção matricial feitos com corpos de prova do topo (AI1), para sucções matriciais de 50 e 100kPa, segundo as condições indicadas no capítulo anterior (Tabela 3.3).

a) Sucção matricial de $50 \mathrm{kPa}$.

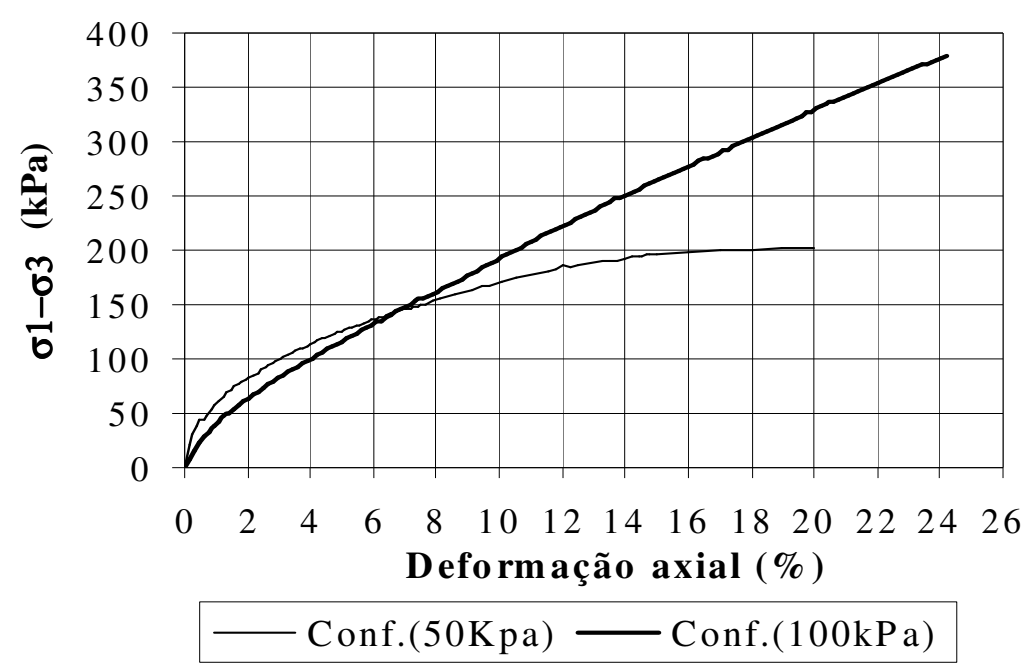

b) Sucção matricial de $100 \mathrm{kPa}$.

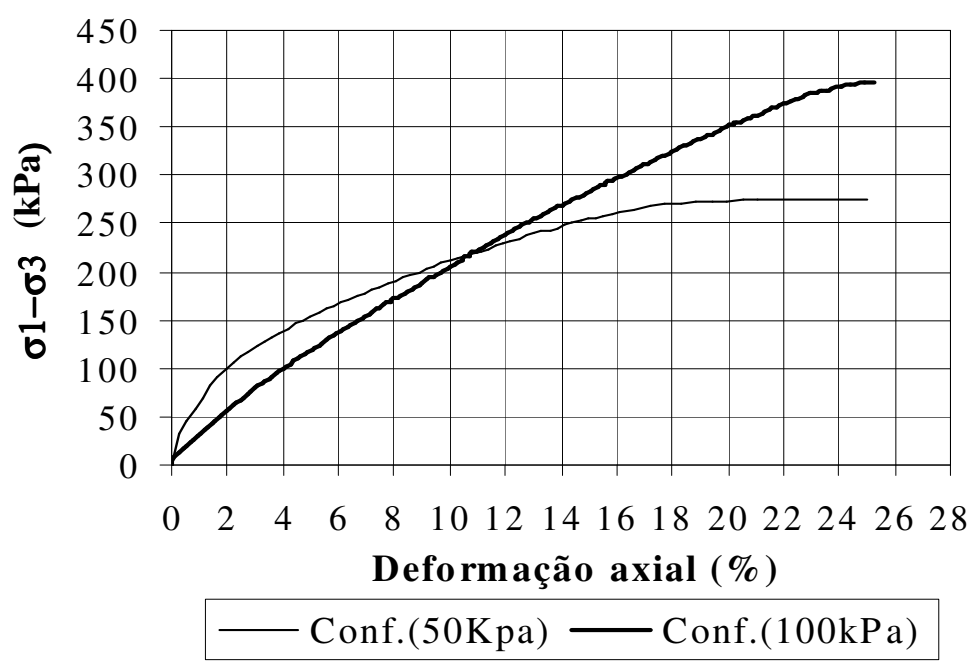

FIGURA 4.13 - Diagramas tensão-deformação para sucções matriciais de 50 e 100kPa. 
Em seguida, na Figura 4.14, mostram-se os diagramas tensão - deformação para sucções matriciais de $30,75,150$ e $300 \mathrm{kPa}$, segundo as condições indicadas no capítulo anterior (Tabela 3.3).

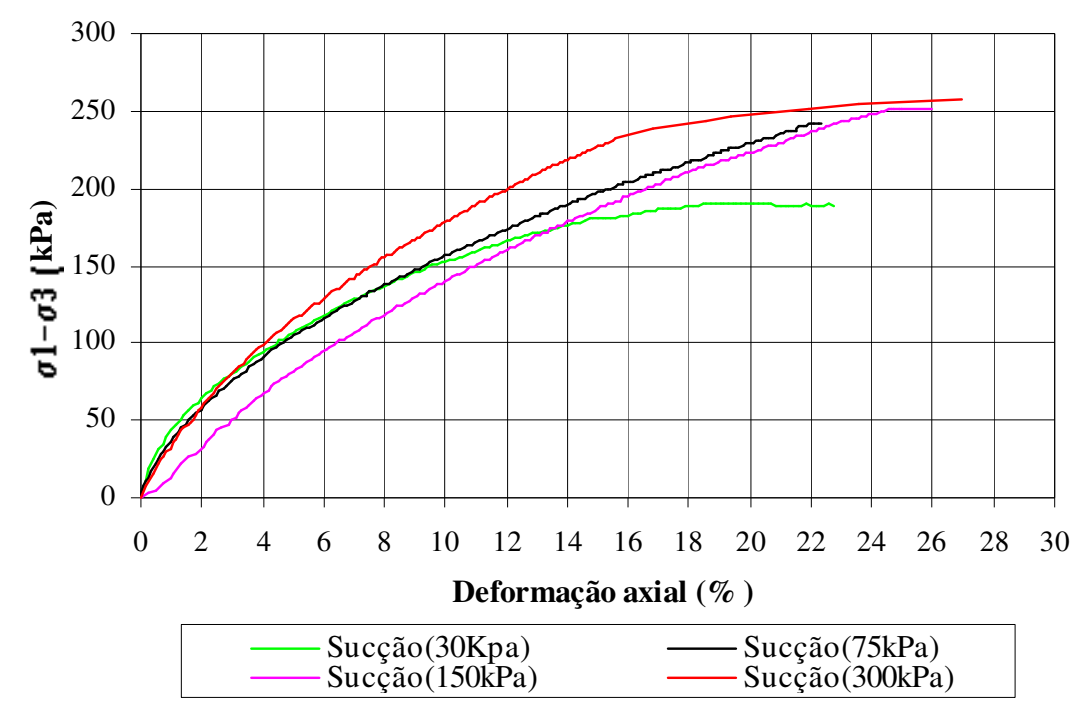

FIGURA 4.14 - Diagrama tensão-deformação para sucções matriciais de 30, 75, 150 e 300kPa.

Em seguida determinaram-se as envoltórias de resistência (equação 2,36), obtidas para amostras do topo com valores de sucção matricial de 50kPa e 100kPa (Figura 4.15).

a) sucção matricial de $50 \mathrm{kPa}$
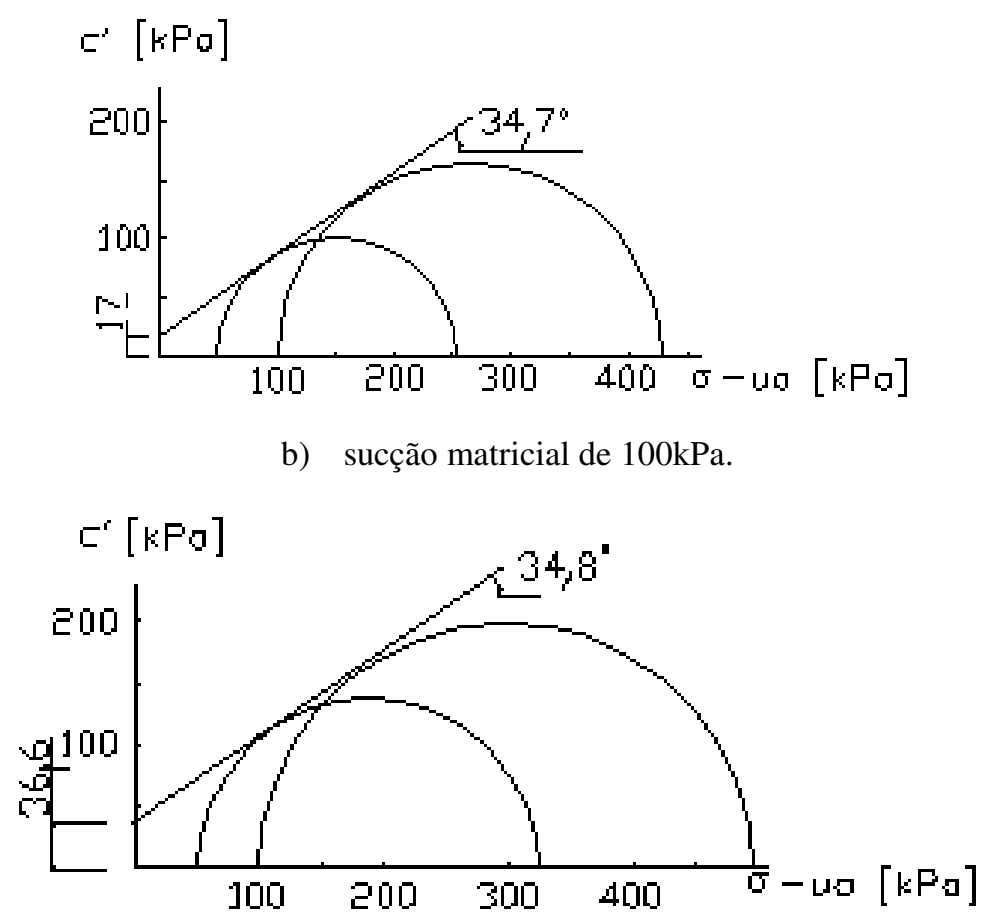

FIGURA 4.15 - Envoltórias de resistência não saturada para sucções de 50 e 100kPa. 
Pode-se verificar que os ângulos de atrito $\left(\phi^{\prime}\right)$ encontrados para os dois casos (Figura 4.15), são semelhantes ao ângulo de atrito encontrado nos ensaios de compressão triaxial consolidado drenado (CD), do topo do talude (equação 4.3). Portanto assumiu-se o mesmo ângulo $\left(\phi^{\prime}=35^{\circ}\right)$, nos ensaios com sucção matricial de $30,75,150$ e $300 \mathrm{kPa}$, com o intuito de obter as coesões associadas a essas sucções matriciais.

Na Tabela 4.6 mostra-se os resultados obtidos nos ensaios triaxiais com controle de sucção matricial.

TABELA 4.6 - Ensaios triaxiais com controle de sucção matricial.

\begin{tabular}{|c|c|c|c|}
\hline $\mathbf{N o}$ & $\mathbf{u}_{\mathbf{a}}-\mathbf{u}_{\mathbf{w}}(\mathbf{k P a})$ & $\boldsymbol{\sigma}_{3}-\mathbf{u}_{\mathbf{a}}(\mathbf{k P a})$ & $\mathbf{c}^{\prime}$ \\
\hline 1 & 30 & 50 & 14,8 \\
\hline 2 & 50 & 50 & 17,0 \\
\hline 3 & 50 & 100 & 17,0 \\
\hline 4 & 75 & 50 & 28,2 \\
\hline 5 & 100 & 50 & 36,6 \\
\hline 6 & 100 & 100 & 36,6 \\
\hline 7 & 150 & 50 & 32,2 \\
\hline 8 & 300 & 50 & 32,4 \\
\hline
\end{tabular}

Nas Figuras 4.16 e 4.17 mostram-se graficamente as envoltórias resultantes dos ensaios triaxiais com controle de sucção matricial.

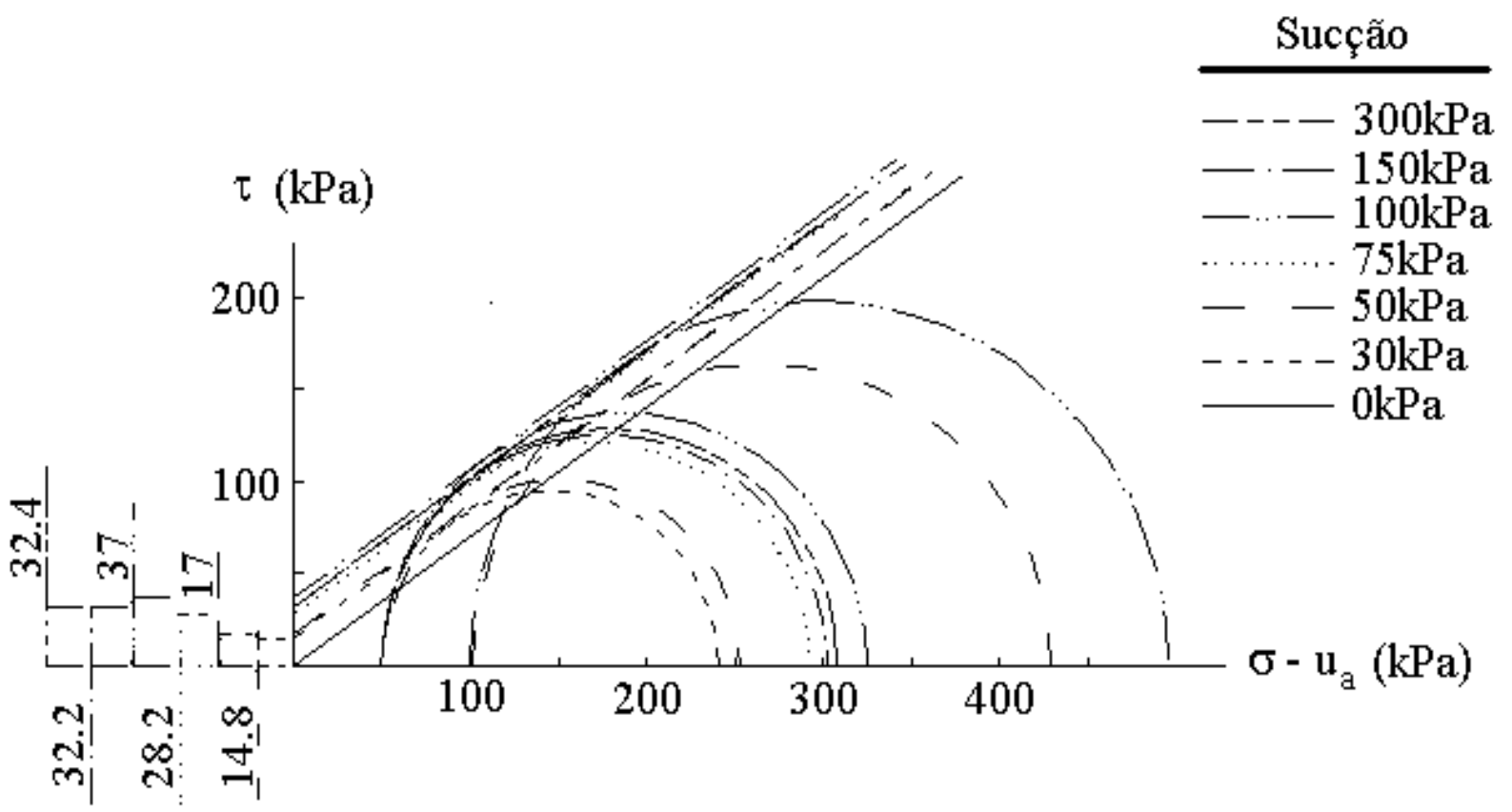

FIGURA 4.16 - Envoltória de resistência não saturada com controle de sucção matricial, círculos de Mohr. 


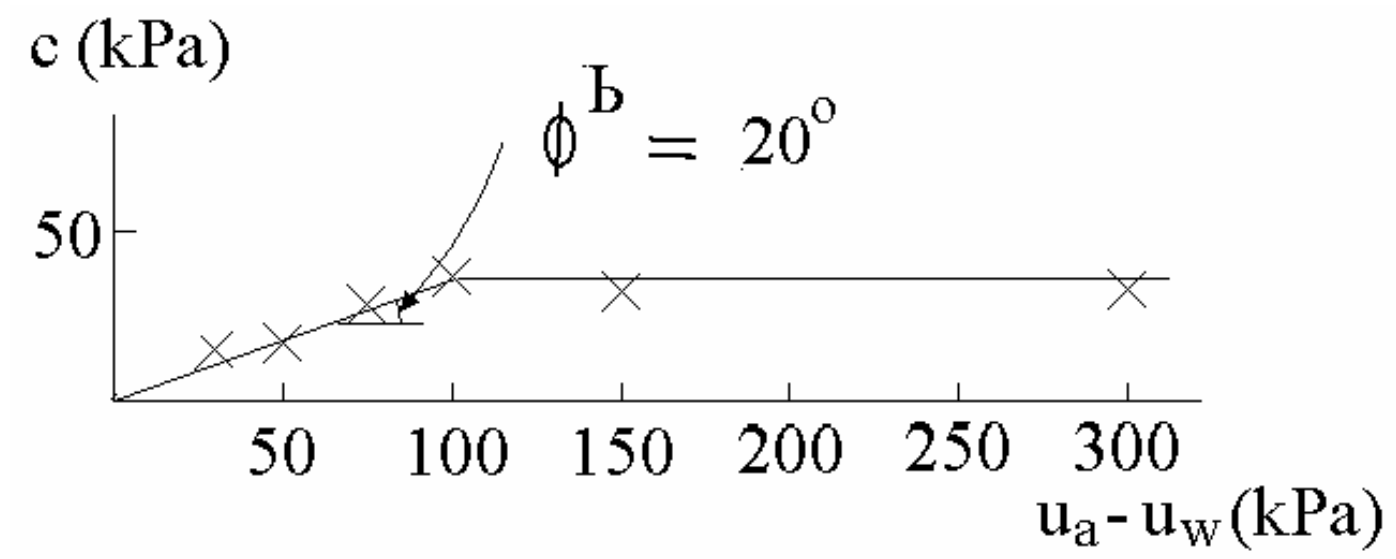

FIGURA 4.17- Envoltória de resistência não saturada com controle de sucção matricial.

Pode-se verificar, na Figura 4.17, que o ângulo de atrito obtido com relação a sucção matricial $\left(\phi^{\mathrm{b}}\right)$, entre valores de sucção matricial de $0 \mathrm{kPa}$ a $100 \mathrm{kPa}$, foi de $20^{\circ}$, que, aparentemente, diminuiu para $0^{\circ} \mathrm{com}$ o aumento de sucção matricial, num comportamento típico de areias, nas quais, o efeito de sucção matricial tende a desaparecer para altas sucções matriciais (Escario \& Sáez, 1986). A faixa de tensões confinantes $\left(\sigma_{3}-u_{a}\right)$ considerada foi de 50 a $100 \mathrm{kPa}$.

No anexo E, mostram-se as características dos corpos de prova utilizados nos ensaios triaxiais com controle de sucção matricial. 


\section{ANÁLISE DE RUPTURA}

No presente capítulo considerou-se os resultados obtidos do capítulo anterior para a realização da modelagem e análise de ruptura do talude estudado.

\subsection{PERFIL DE SUCÇÃO MATRICIAL INICIAL “IN SITU”}

Considerando-se as máximas sucções matriciais obtidas "in situ" pelos tensiômetros, entre valores de 50 a $60 \mathrm{kPa}$ na base da fenda (Figura 4.6), tratou-se de obter o perfil inicial de sucções matriciais no talude, na sua configuração original empregando-se o programa SEEP/W. Para tanto, assumiu-se o nível de água (sucção matricial nula) na profundidade de 25m, um solo homogêneo e seco com características do solo do topo (AI1), a continuidade infinita dos lados direito e esquerdo do talude e um estado de fluxo transiente. Utilizaram-se também, a função da condutividade hidráulica não saturada (equação 4.1) e a função da curva de retenção (equação 4.2).

Uma vez discretizado o talude e considerando-se as condições iniciais mencionadas, adicionou-se uma precipitação qualquer constante, aplicada sobre toda a superfície exposta do talude, durante tempos diferentes crescentes de precipitação. O programa mostrou diferentes perfis de sucção matricial para cada tempo utilizado. O tempo que proporcionou o perfil mais próximo do registrado em campo pelos tensiômetros, foi o adotado como o perfil de sucção matricial in situ (Figura 5.1).

Cabe ressaltar que o programa considerou a pressão de ar nula, portanto a pressão da água do solo foi equivalente a sucção do solo. 


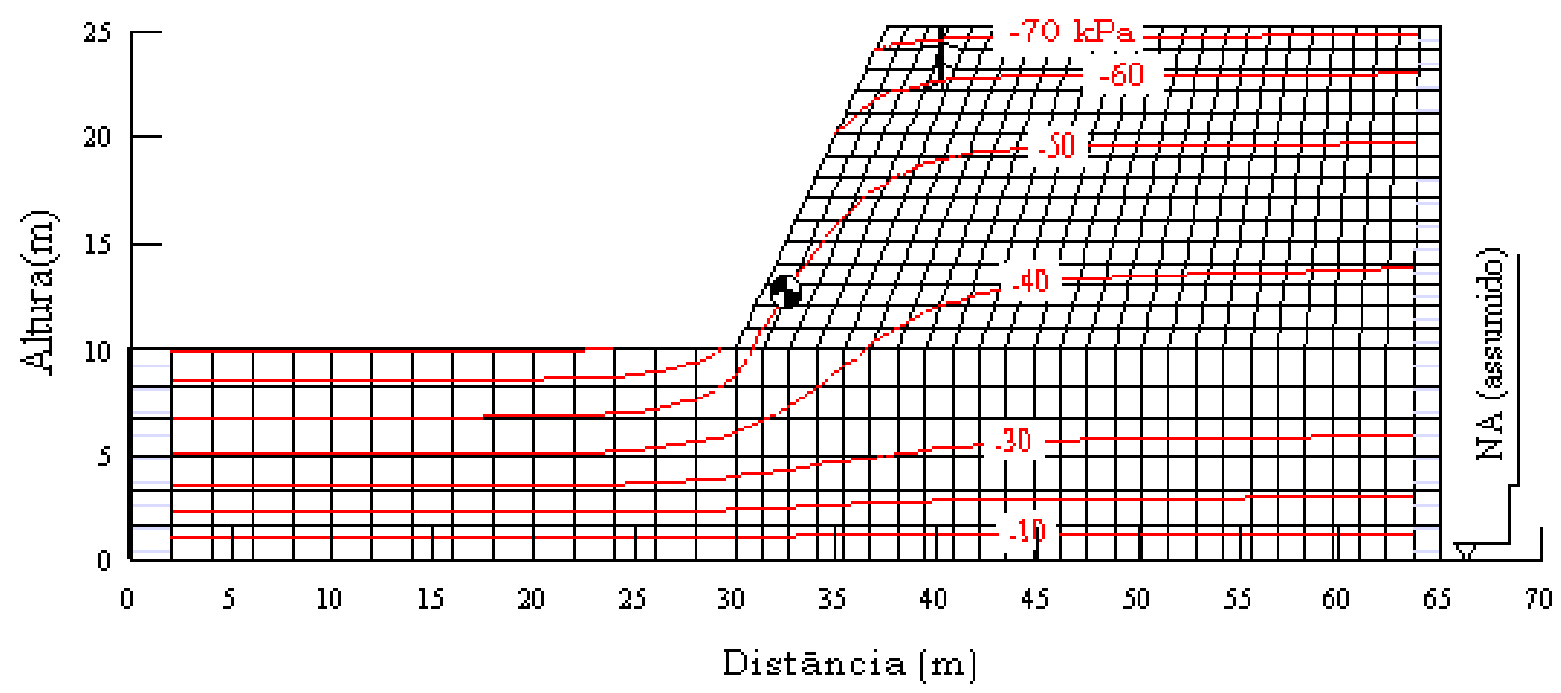

FIGURA 5.1 - Perfil de sucção matricial inicial adotado.

\subsection{ANÁLISE DE ESTABILIDADE PARA AS CONDIÇÕES INICIAIS}

Nas condições iniciais de sucção matricial do ítem anterior (Figura 5.1) verificou-se qual seria o fator de segurança do talude sem consideração da fenda de tração. Para tanto, analisou-se o talude considerando-se as características do solo do topo obtidas no capítulo anterior $\left(\rho=1,6 \mathrm{~g} / \mathrm{cm}^{3}, \mathrm{c}^{\prime}=0 \mathrm{kPa}, \phi^{\prime}=35^{\circ}\right.$, e $\left.\phi^{\mathrm{b}}=20^{\circ}\right)$, para o solo não saturado. Para o solo totalmente saturado fez-se unicamente $\phi^{\mathrm{b}}=0^{\circ}$.

$\mathrm{Na}$ condição não saturada encontrou-se um fator de segurança de 1,126, correspondente ao círculo representado na Figura 5.2. Caso o solo estivesse saturado o fator de segurança na mesma superfície de ruptura seria de 0,636.

Em função do baixo fator de segurança encontrado na condição não saturada, é lícito supor que a ruptura tenha se dado por uma redução de sucção matricial e, por extensão, de resistência, sem, contudo, ter-se a saturação do solo. De fato, verifica-se que se o solo estivesse totalmente saturado não seria estável, tendo-se um fator de segurança inferior a 1. Portanto o talude poderia ter escorregado em estado não saturado.

Observa-se também que a superfície de ruptura fornecida pelo programa, sem consideração da fenda $(\mathrm{r}=18,1 \mathrm{~m})$, é próxima à superfície de ruptura observada em campo $(r=19,9 m)$, como mostrada na Figura 3.1-b. 


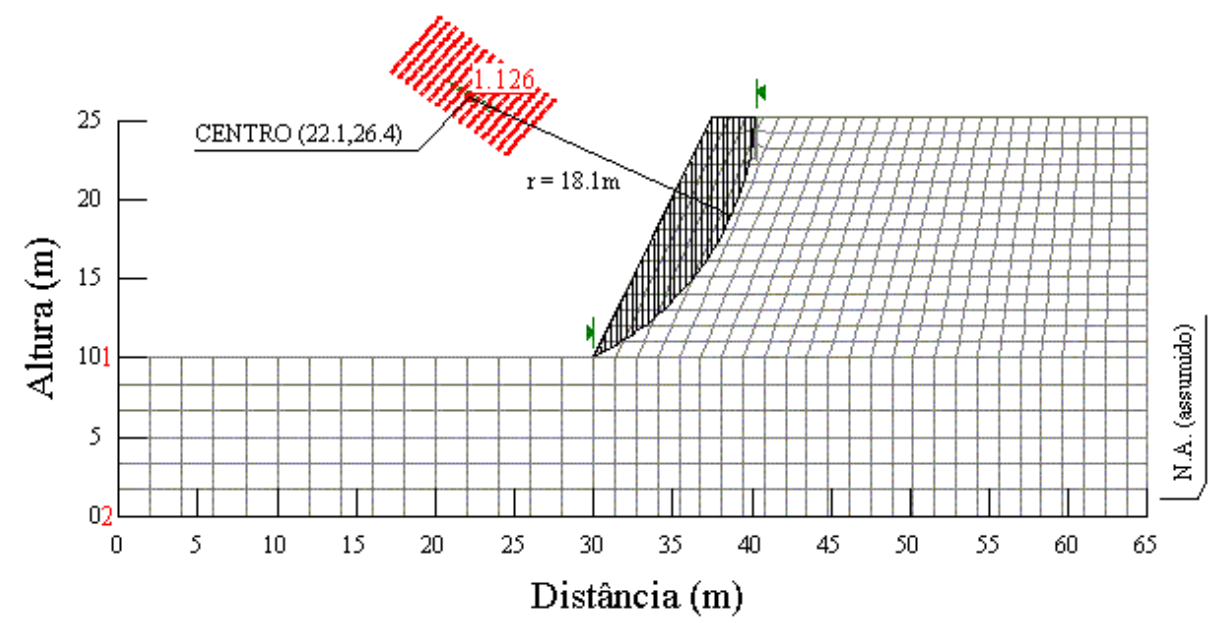

FIGURA 5.2 - Fator de segurança em condições iniciais sem consideração da fenda.

\subsection{DEFINIÇÃO DA SUPERFÍCIE DE RUPTURA CONSIDERANDO-SE A FENDA DE TRAÇÃO}

Observou-se em campo que a fenda de tração, encontrada na superfície de ruptura escorregada, continua através do talude ainda não escorregado (ver Figuras 3.1-b e 3.4), portanto adotou-se que a superfície do escorregamento definida pelo programa deveria incluir a base da fenda de tração.

Em seguida, analisaram-se várias superfícies de ruptura, considerando-se a fenda de tração. Observou-se que a situação mais crítica corresponde ao círculo mostrado na Figura 5.3, onde o fator de segurança foi de 1,067, com fenda preenchida de água, e 1,089 com fenda seca. No caso da superfície adotada em campo (Figura 3.1-b) o fator de segurança foi de 1,077 com fenda preenchida de água e 1,100 com fenda seca.

Observou-se que a superfície mais crítica corresponde a uma superfície de ruptura profunda que começa próxima a base do talude até a base da fenda. Esta superfície está muito próxima da encontrada em campo e da encontrada no ítem 5.2.

A superfície de ruptura com fenda preenchida de água resultou ter maior curvatura em relação à superfície de ruptura encontrada sem consideração da fenda e da adotada em campo, incrementando-se o raio de curvatura em $22 \%$ em relação à primeira e $11 \%$ em relação à segunda, sendo que o fator de segurança diminuiu em 5,5\% em relação à primeira e 0,9\% em relação à segunda. Portanto, verificou-se que a superfície de ruptura com fenda preenchida de água foi a mais próxima da superfície de ruptura adotada em campo, em consequiência, a 
superfície crítica de ruptura com fenda preenchida de água (Figura 5.3) foi a adotada como superfície assumida na análise de ruptura ao longo do presente trabalho.

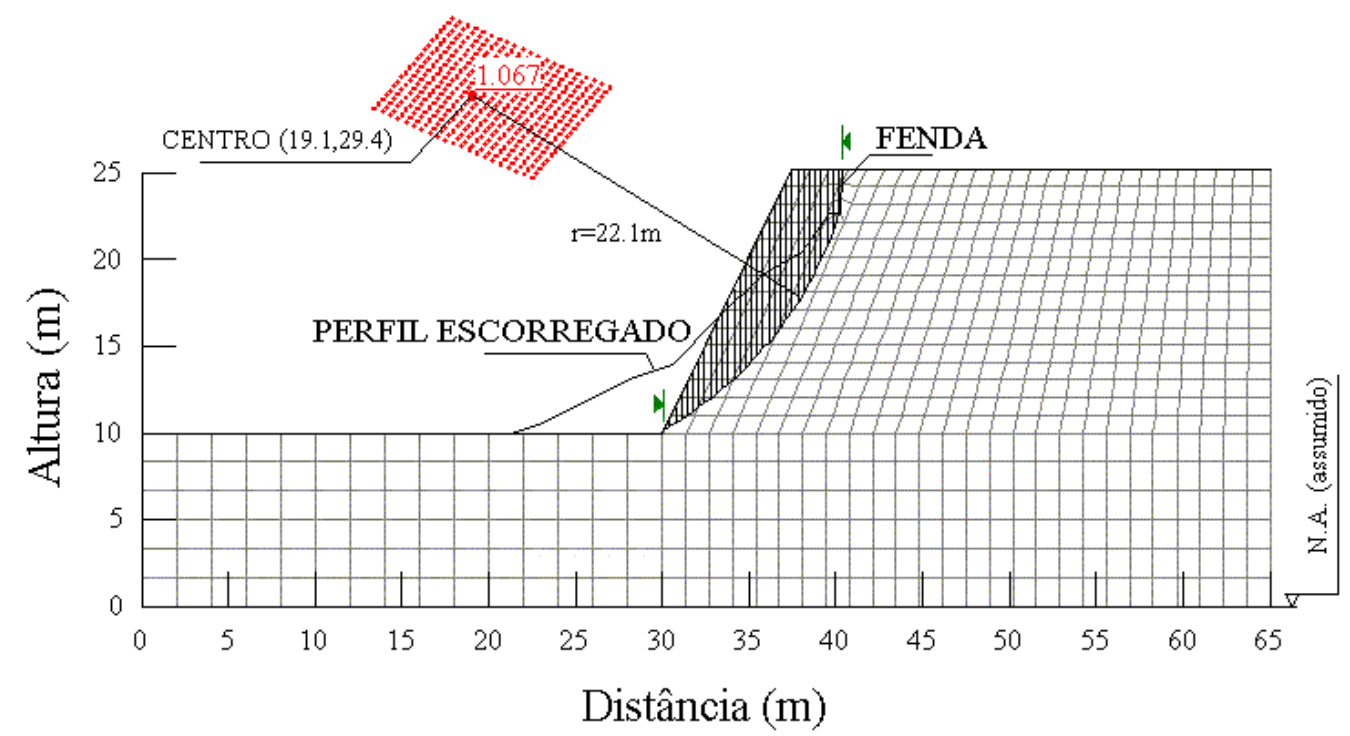

FIGURA 5.3 - Definição da superfície de ruptura considerando fenda de tração.

\subsection{INFLUÊNCIA DA PRECIPITAÇÃO NO AVANÇO DA FRENTE DE UMEDECIMENTO.}

A partir das constatações iniciais, passou-se a analisar a influência da precipitação no avanço da frente de umedecimento do talude. Para esta análise utilizou-se o procedimento semelhante ao ítem 5.1, com 2 modificações: (a) a precipitação foi definida com valores conhecidos $(20 \mathrm{~mm} / \mathrm{h}$ e $70 \mathrm{~mm} / \mathrm{h})$ e (b) utilizou-se o perfil de sucção inicial in situ, obtido no ítem 5.1, como condição inicial.

Nas Figuras 5.4 e 5.5, ilustram-se o avanço da frente de umedecimento considerandose uma chuva de $20 \mathrm{~mm} / \mathrm{h}$ e $70 \mathrm{~mm} / \mathrm{h}$, em função do tempo de precipitação. Durante o avanço desta frente, as pressões neutras tornam-se positivas na parte saturada e permanecem negativas sob o mesmo.

Nas Figuras 5.6 e 5.7, podem-se observar a variação das pressões neutras para tempos de 3 e $25 \mathrm{~h}$ respectivamente, para uma precipitação de $20 \mathrm{~mm} / \mathrm{h}$. Pode-se constatar nestas Figuras que a frente de umedecimento avança verticalmente com a profundidade.

A análise da influência da precipitação no avanço da frente de umedecimento do talude, foi feita também para uma precipitação de $70 \mathrm{~mm} / \mathrm{h}$. As Figuras 5.8 e 5.9 mostram os resultados para tempos de precipitação de 3 e $15 \mathrm{~h}$. 


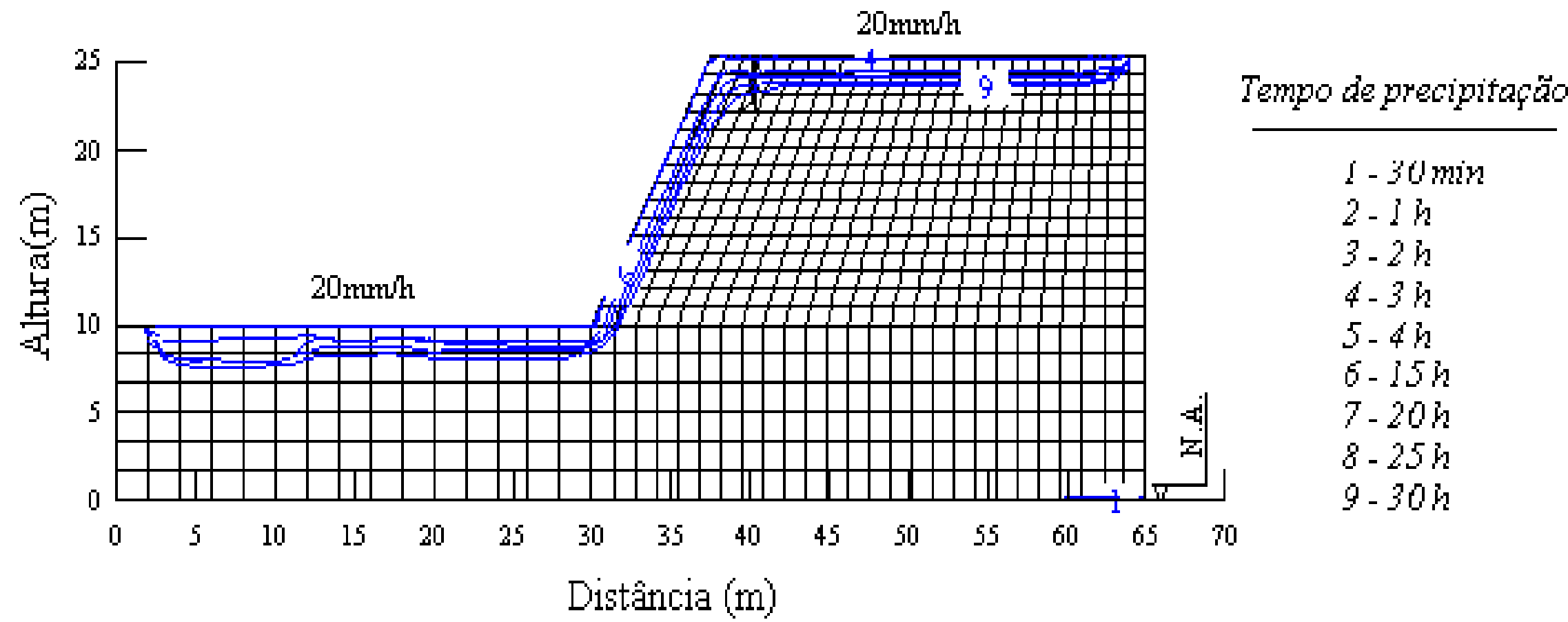

FIGURA 5.4 - Variação da frente de umedecimento ocasionada por uma precipitação de 20mm/h. 


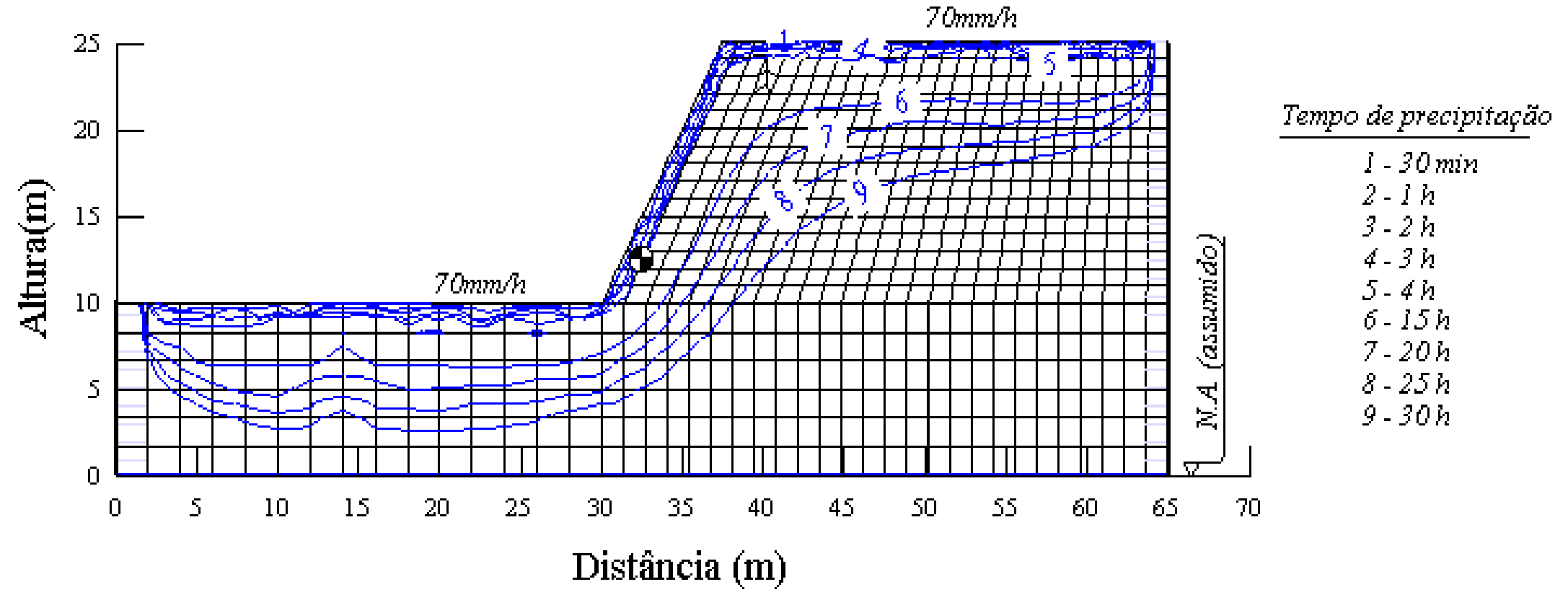

FIGURA 5.5 - Variação da frente de umedecimento ocasionada por uma precipitação de $70 \mathrm{~mm} / \mathrm{h}$. 


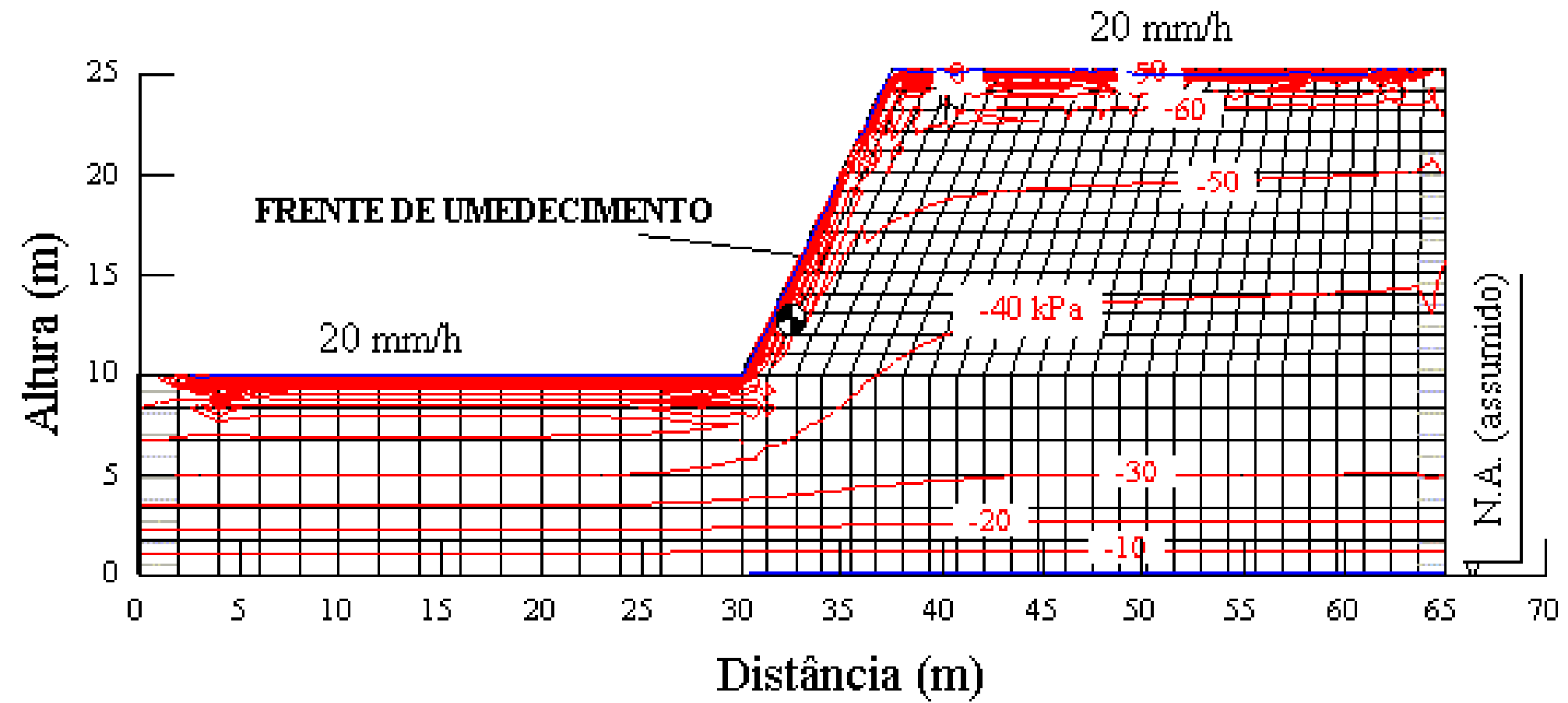

FIGURA 5.6 - Sucção no solo em kPa após 3h de uma precipitação de 20mm/h. 
$20 \mathrm{~mm} / \mathrm{h}$

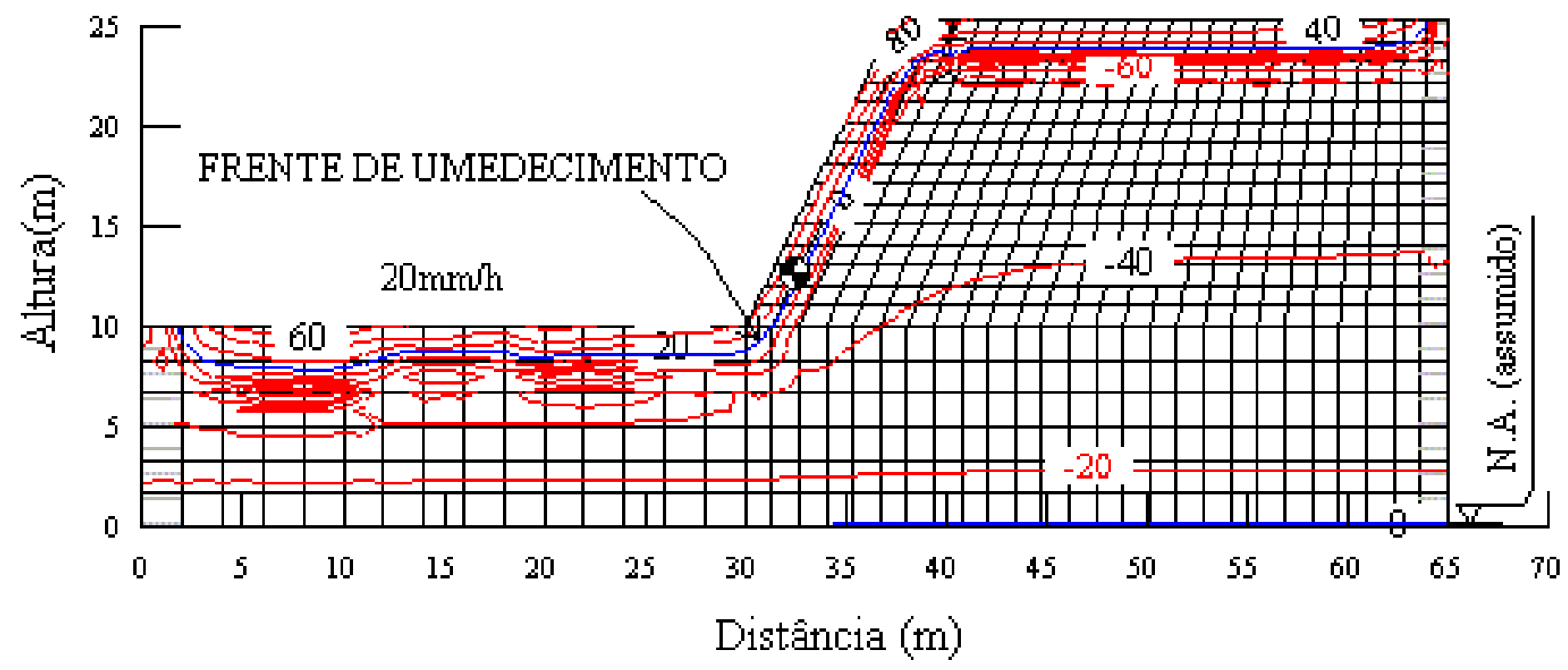

FIGURA 5.7 - Sucção no solo em kPa após $25 \mathrm{~h}$ de uma precipitação de 20mm/h 


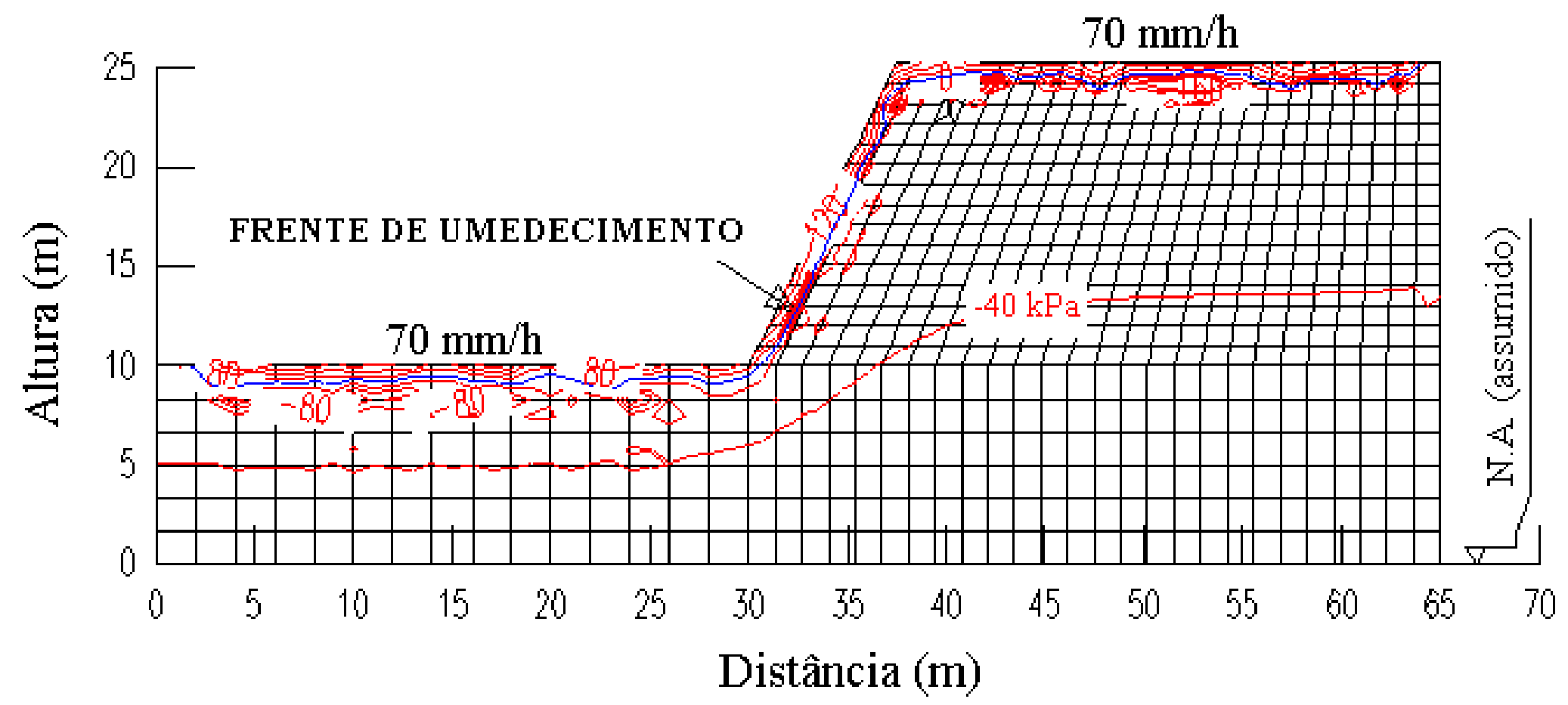

FIGURA 5.8 - Sucção no solo em kPa após 3h de uma precipitação de 70mm/h. 


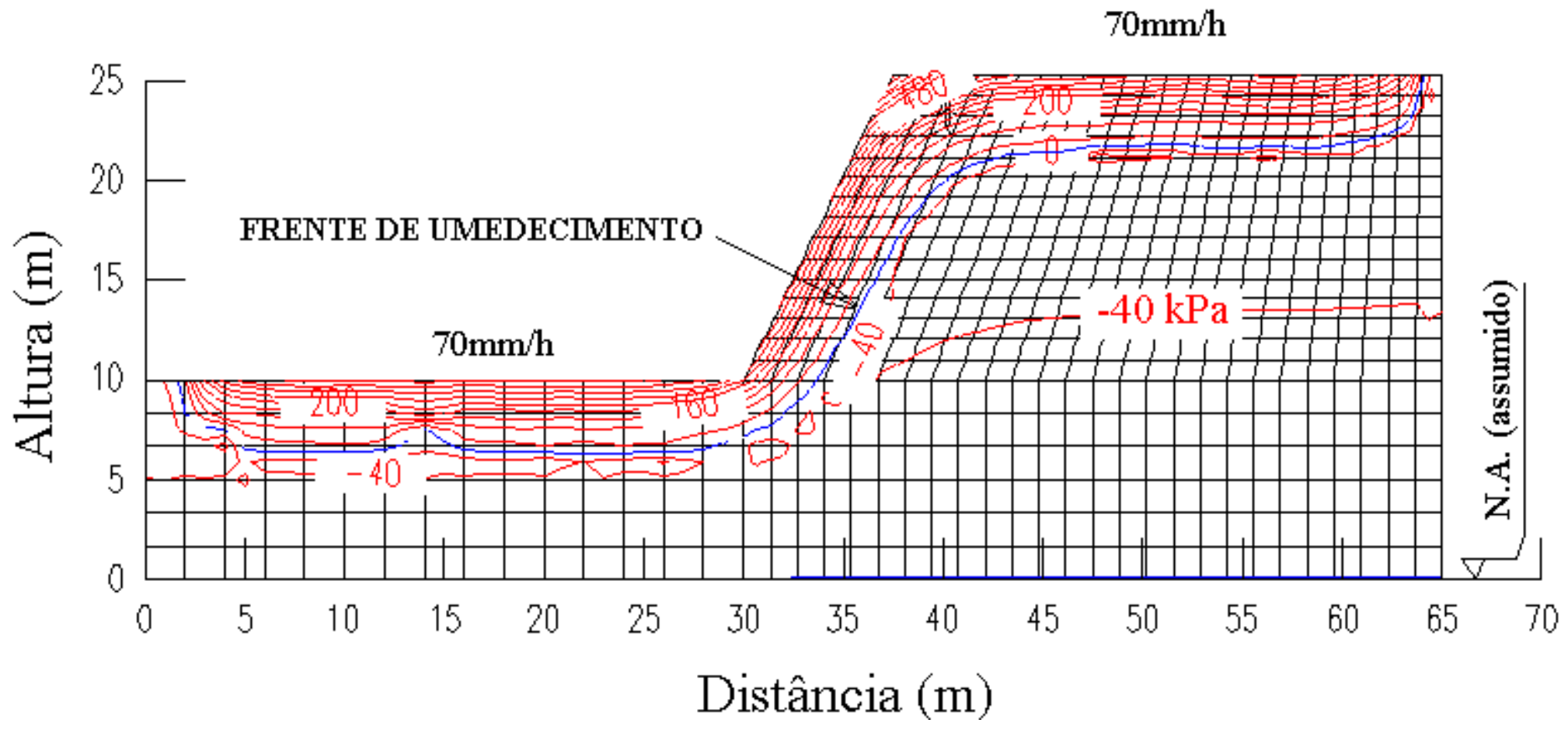

FIGURA 5.9 - Sucção no solo em kPa após $15 \mathrm{~h}$ de uma precipitação de 70mm/h. 


\subsection{FATORES DE SEGURANÇA OBTIDOS COM OS PARÂMETROS DOS ENSAIOS CD E UU.}

Em seguida, fizeram-se várias simulações acerca da estabilidade do talude, com o propósito de comparar 4 casos específicos, os dois primeiros considerando-se um único solo e os dois últimos considerando-se dois tipos de solos. Compararam-se também os fatores de segurança da superfície assumida respeito às superfícies fornecidas pelo programa.

No programa utilizou-se como condições iniciais os perfis de sucção matricial obtidos no ítem 5.4 para determinar o fator de segurança.

\section{a) Análise da superfície de ruptura assumida considerando o talude formado por um solo.}

Neste caso determinaram-se os fatores de segurança para a superfície de ruptura assumida no presente trabalho (Figuras 5.3 e 3.1-b), considerando-se um único solo com características do solo do topo AI1 (Tabela 5.1).

Na Tabela 5.1 apresentam-se, entre colchetes, os centros das superfícies críticas de ruptura, para cada caso analisado correspondentes a um raio de $22,1 \mathrm{~m}$, bem como os FS obtidos.

TABELA 5.1 - Fatores de segurança considerando-se a superfície de ruptura assumida para o talude formado por um solo.

\begin{tabular}{|l|c|c|c|c|c|}
\cline { 2 - 6 } \multicolumn{1}{c|}{} & FS & $\phi^{\prime}$ & $\mathrm{c}^{\prime}$ & $\phi \mathrm{b}$ & Ensaio \\
\hline 1) Solo "in situ" inicial com sucção & $1,07[19.1,29.4]$ & 35 & 0 & 20 & $\mathrm{CD}$ \\
\hline 2) Solo $\ddot{n}$ situ" +Precipitação de 20mm/h $(\mathrm{t}=2 \mathrm{~h})$ & $1,06[19.1,29.4]$ & 35 & 0 & 20 & $\mathrm{CD}$ \\
\hline 3) Solo "in situ"+ Precipitação de 20mm/h $(\mathrm{t}=15 \mathrm{~h})$ & $0,98[19.1,29.4]$ & 35 & 0 & 20 & $\mathrm{CD}$ \\
\hline 4) Solo "in situ"+Precipitação de 70mm/h $(\mathrm{t}=30 \mathrm{~min})$ & $1,05[19.1,29.4]$ & 35 & 0 & 20 & $\mathrm{CD}$ \\
\hline 5) Solo "in situ"+Precipitação de 70mm/h (t=2h) & $1,00[19.1,29.4]$ & 35 & 0 & 20 & $\mathrm{CD}$ \\
\hline 6) Solo saturado & $0,60[19.1,29.4]$ & 35 & 0 & 0 & $\mathrm{CD}$ \\
\hline 7) Situação não drenada & $0,64[19.1,29.4]$ & 22.3 & 11 & 0 & $\mathrm{UU}$ \\
\hline
\end{tabular}

Pode-se verificar na Tabela anterior que o fator de segurança obtido nas condições iniciais, após duas horas de precipitação de $20 \mathrm{~mm} / \mathrm{h}$ não sofreu quase nenhuma alteração, no entanto, depois de 15 horas de precipitação, aproximadamente, o fator de segurança reduziuse para menos que 1,0 . No caso de acontecer uma precipitação de $70 \mathrm{~mm} / \mathrm{h}$ o FS tornou-se inferior a 1,0 em um tempo próximo de 2 horas. 
Pode-se observar também que no caso do solo saturado ou na situação não drenada o fator de segurança é bem menor que 1 , o que sugere que a ruptura do talude se deu em condições não saturadas.

\section{b) Análise da superfície de ruptura fornecida pelo método de Bishop considerando o talude formado por um solo.}

Neste caso calcularam-se os fatores de segurança de acordo com o método de Bishop (1955), onde a superfície de ruptura fornecida correspondeu a superfície mais crítica de várias superfícies testadas pelo método.

O talude em análise nesta face foi considerado composto por um único solo com características do solo do topo (AI1).

Na Tabela 5.2 aparecem, entre colchetes, os centros das superfícies de ruptura e os raios correspondentes para sete casos estudados, bem como os FS obtidos.

TABELA 5.2 - Fatores de segurança considerando-se a superfície de ruptura fornecida para um único solo.

\begin{tabular}{|l|c|c|c|c|c|c|}
\cline { 2 - 6 } \multicolumn{1}{c|}{} & FS & raio $(\mathrm{m})$ & $\phi^{\prime}$ & $\mathrm{c}^{\prime}$ & $\phi \mathrm{b}$ & Ensaio \\
\hline 1) Solo "in situ" inicial com sucção & $1,07[19.1,29.4]$ & 22,1 & 35 & 0 & 20 & $\mathrm{CD}$ \\
\hline 2) Solo $\ddot{n}$ situ" +Precipitação de 20mm/h (t=2h) & $1,06[19.1,29.4]$ & 22 & 35 & 0 & 20 & $\mathrm{CD}$ \\
\hline 3) Solo "in situ"+ Precipitação de 20mm/h (t=15h) & $0,10[22.6,31.6]\left({ }^{1}\right)$ & 17,4 & 35 & 0 & 20 & $\mathrm{CD}$ \\
\hline 4) Solo "in situ"+Precipitação de 70mm/h $(\mathrm{t}=30 \mathrm{~min})$ & $1,00[18.3,33.2]\left({ }^{1}\right)$ & 24,4 & 35 & 0 & 20 & $\mathrm{CD}$ \\
\hline 5) Solo "in situ"+Precipitação de 70mm/h $(\mathrm{t}=2 \mathrm{~h})$ & $0,12[25,31.8]\left({ }^{1}\right)$ & 15 & 35 & 0 & 20 & $\mathrm{CD}$ \\
\hline 6) Solo saturado & $0,26[19.9,35]\left({ }^{1}\right)$ & 20 & 35 & 0 & 0 & $\mathrm{CD}$ \\
\hline 7) Situação não drenada & $0,63[16.8,31.2]$ & 22 & 22.3 & 11 & 0 & $\mathrm{UU}$ \\
\hline
\end{tabular}

( ${ }^{1}$ Superfície de ruptura crítica menor a superfície crítica assumida, ruptura superficial.

Os resultados da Tabela anterior apresentam-se graficamente nas Figuras 5.10 a 5.16.

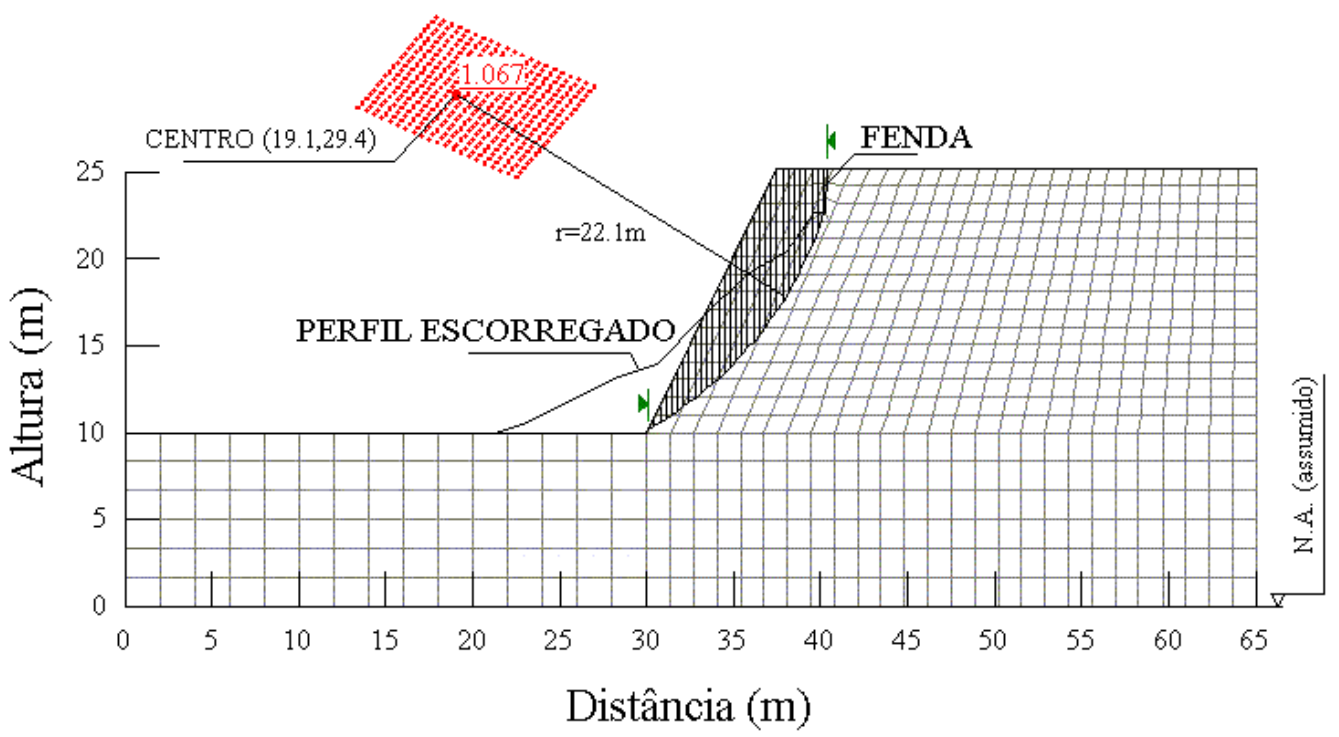

FIGURA 5.10 - Superfície de ruptura para o caso b-1. 


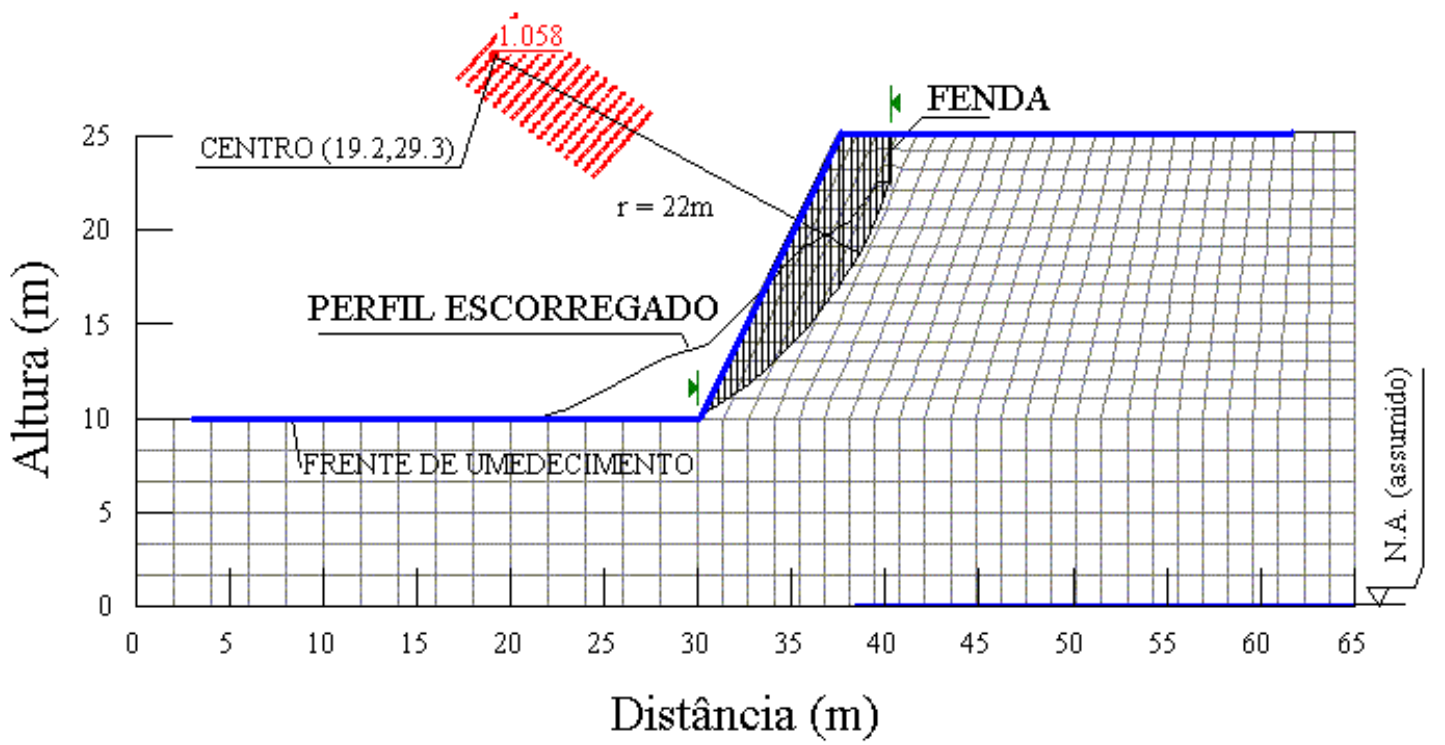

FIGURA 5.11 - Superfície de ruptura para o caso b-2.

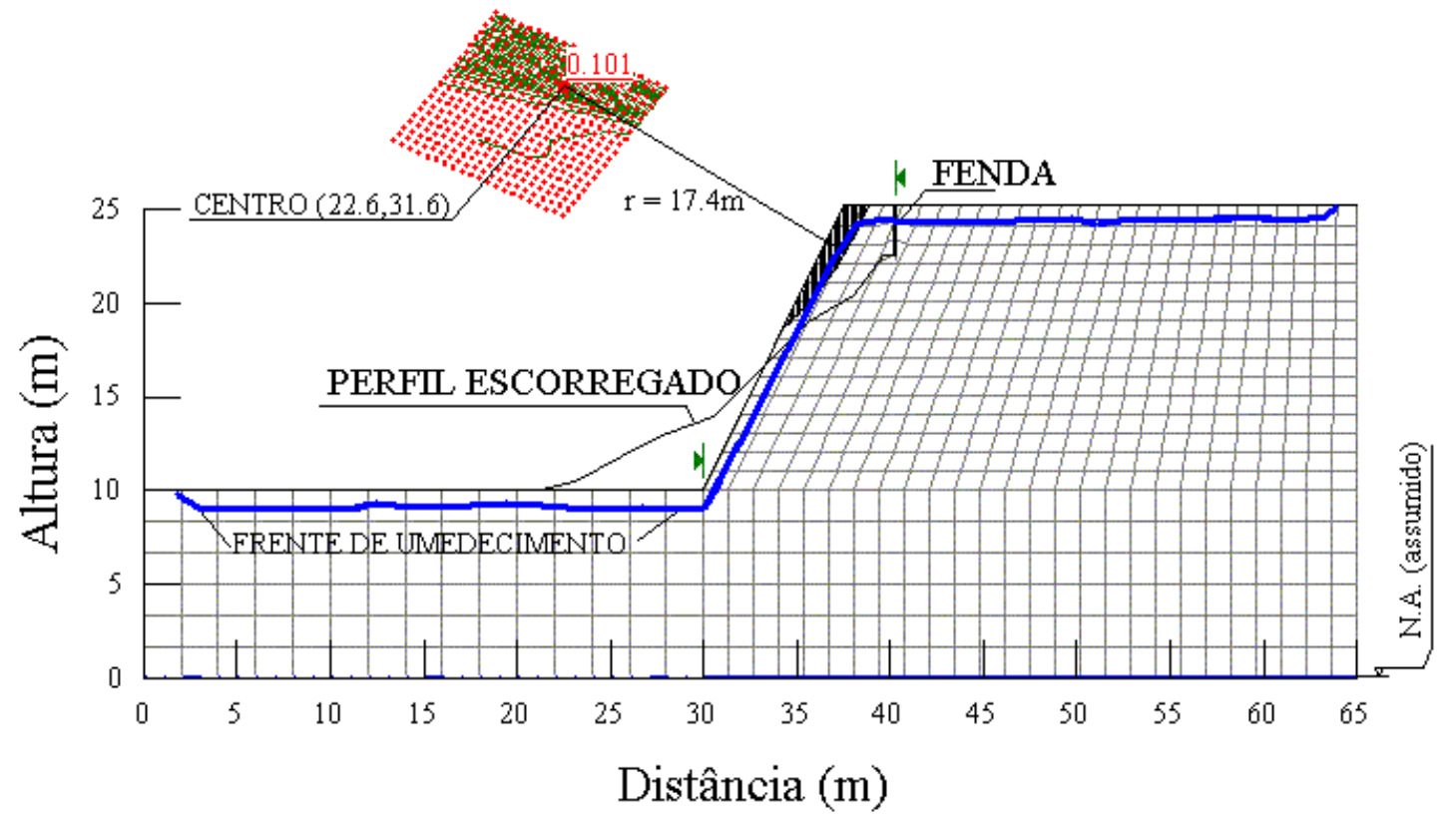

FIGURA 5.12 - Superfície de ruptura para o caso b-3. 


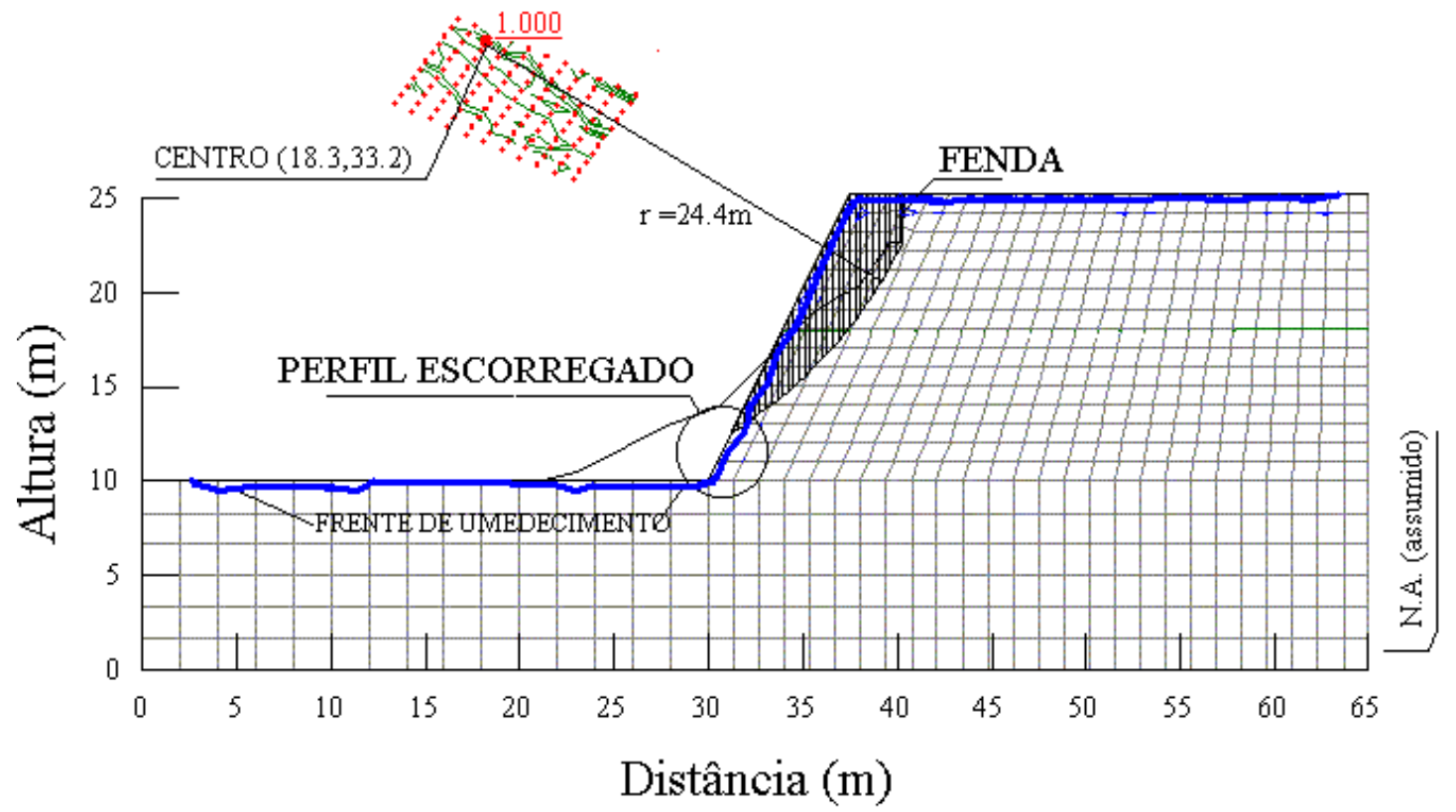

FIGURA 5.13 - Superfície de ruptura para o caso b-4.

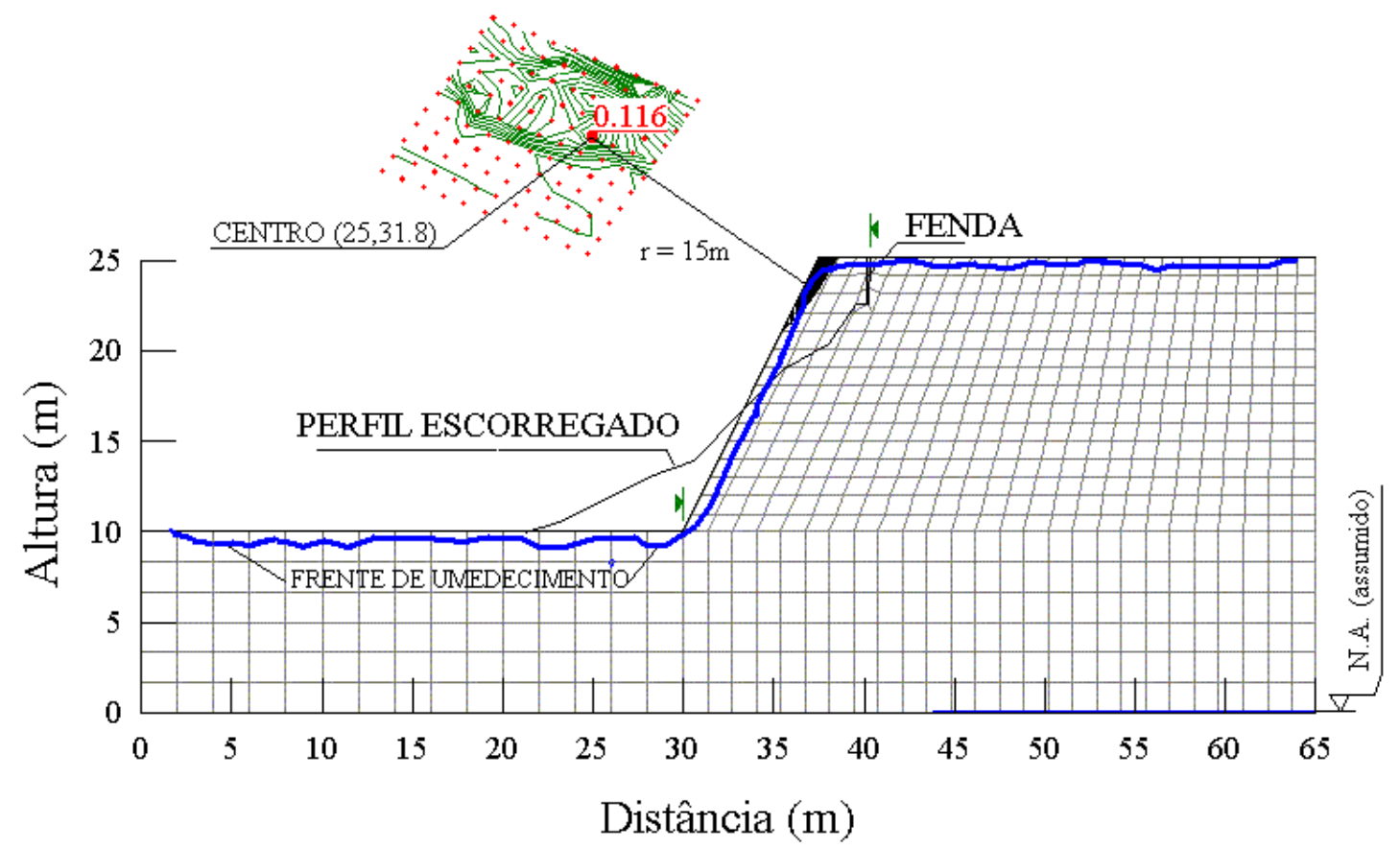

FIGURA 5.14 - Superfície de ruptura para o caso b-5. 


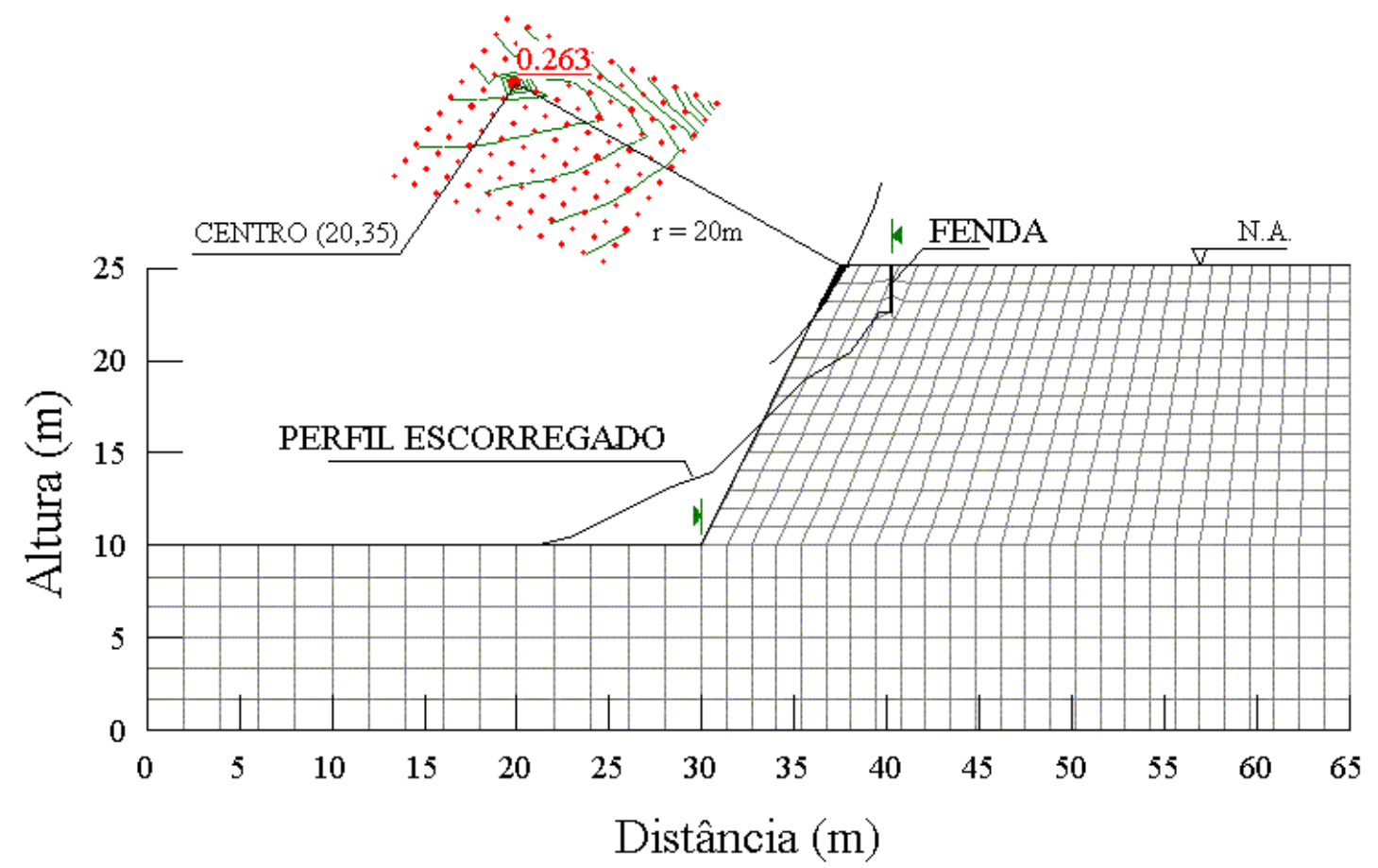

FIGURA 5.15 - Superfície de ruptura para o caso b-6.

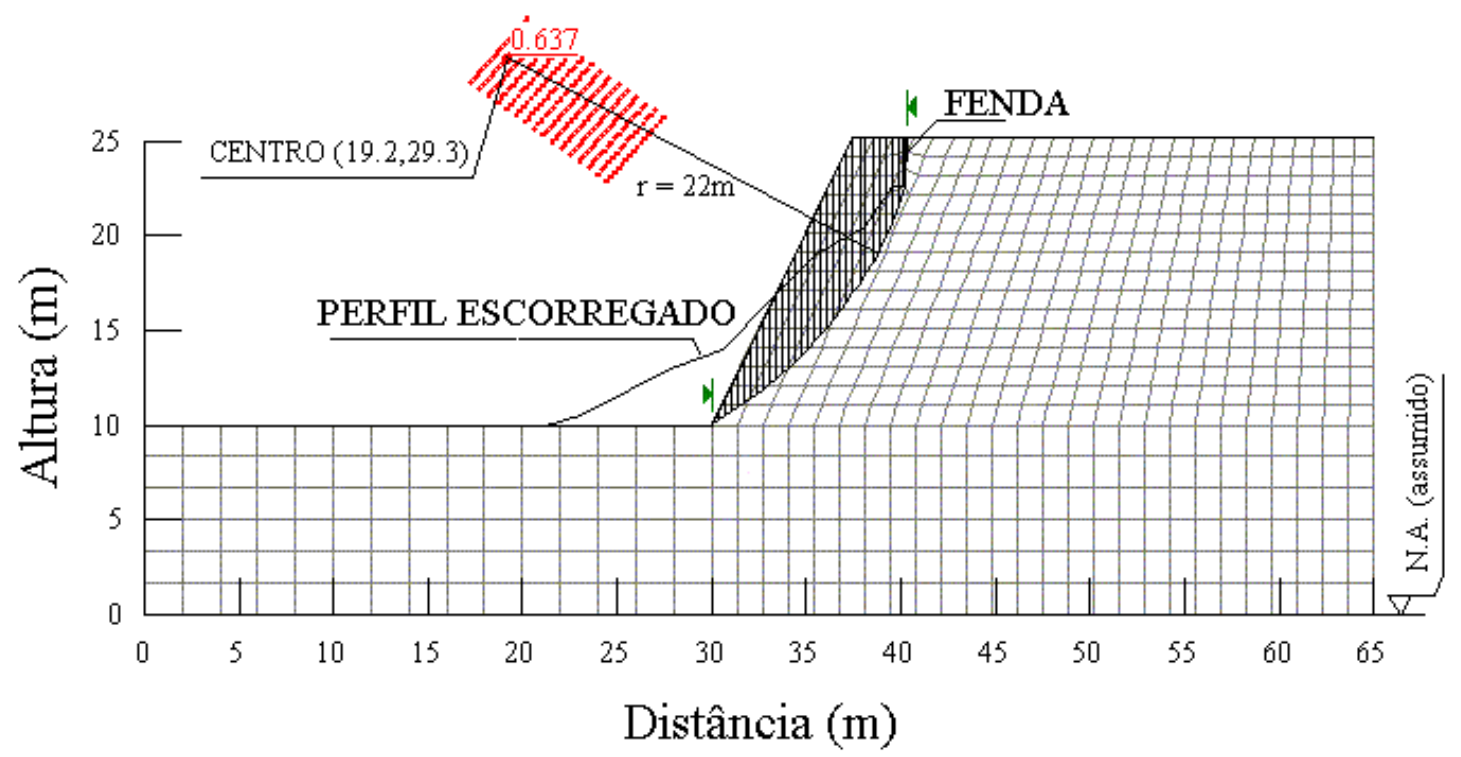

FIGURA 5.16 - Superfície de ruptura para o caso b-7. 
$\mathrm{Na}$ Tabela 5.2 pode-se observar que quando o solo foi considerado em suas condições iniciais (Figura 5.10), ou depois de duas horas de uma precipitação de 20mm/h (Figura 5.11), ou na situação não drenada (Figura 5.16), os resultados do fator de segurança e raios das superfícies de ruptura foram muito próximos aos resultados encontrados quando a superfície de ruptura foi assumida. No caso de uma precipitação de 70mm/h para 30min (Figura 5.13), a superfície de ruptura e raio da mesma não coincidiram com a superfície assumida, apresentando um fator de segurança próximo a 1.

Pode-se verificar, também, que nos casos de $15 \mathrm{~h}$ de precipitação para $20 \mathrm{~mm} / \mathrm{h}, 2 \mathrm{~h}$ de precipitação para $70 \mathrm{~mm} / \mathrm{h}$ e no caso saturado (Figuras 5.12, 5.14 e 5.15), as superfícies de ruptura são superficiais, não atingindo a base da fenda nem a base do talude. Esta é uma constatação interessante que pode explicar os muitos escorregamentos superficiais observados na região. A medida que avança a frente de umedecimento, o solo nela contido satura-se e está sujeito a esses pequenos escorregamentos, anteriormente ao escorregamento geral que envolve uma maior porção de solo.

\section{c) Análise da superfície de ruptura assumida considerando o talude formado por dois solos.}

Neste caso novamente foi analisado o fator de segurança na superfície assumida no ítem 5.3, mas considerando-se o talude composto de dois solos com resistências diferentes. O solo do topo (SOLO 1) estende-se até $12 \mathrm{~m}$ de profundidade, quando principia a ocorrer o solo da base(SOLO 2).

Na Figura 5.17, apresenta-se o perfil do talude, onde o SOLO 1 tem as características do solo da amostragem indeformada do topo (AI1) e o SOLO 2 as características da amostragem indeformada da base (AI2). Mostram-se também o raio e o centro da superfície de ruptura assumida.

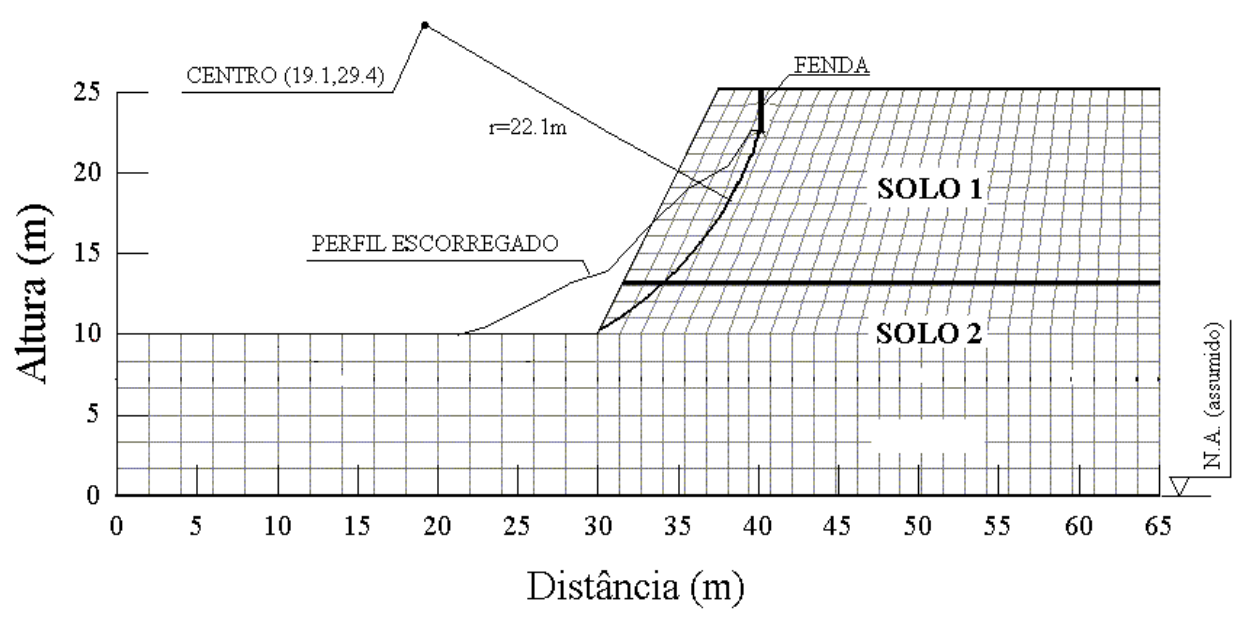

FIGURA 5.17 - Perfil do talude considerando-se os dois solos encontrados na sondagem. 
$\mathrm{Na}$ Tabela 5.3 mostram-se os resultados encontrados para 7 casos analisados considerando-se a superfície de ruptura assumida, de raio $22,1 \mathrm{~m}$ e de centro indicado entre colchetes.

TABELA 5.3 - Fatores de segurança considerando-se a superfície de ruptura assumida para dois solos.

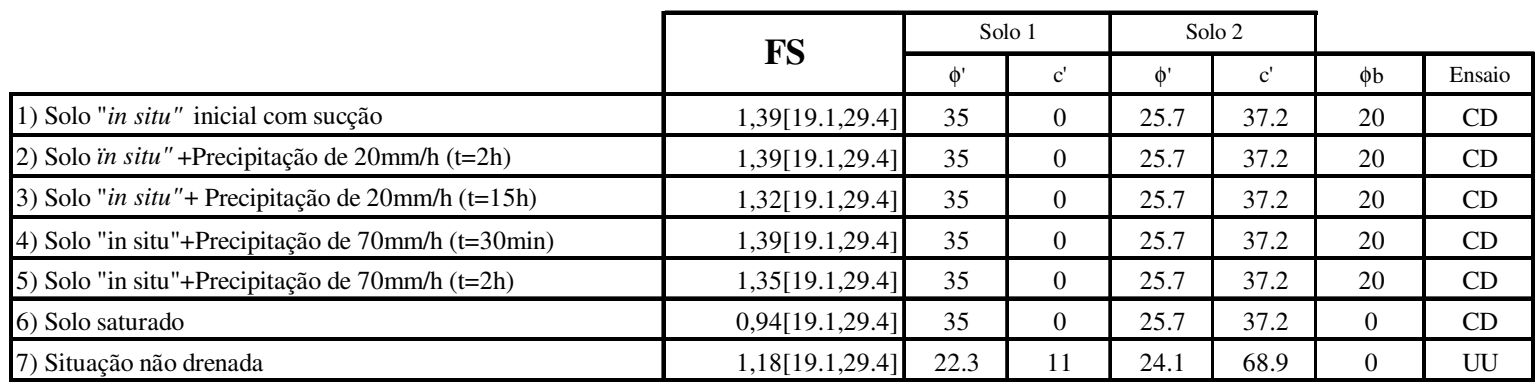

Pode-se verificar que nos casos in situ e nos casos onde foi considerada a precipitação de $20 \mathrm{~mm} / \mathrm{h}$ e $70 \mathrm{~mm} / \mathrm{h}$ os fatores de segurança incrementaram-se aproximadamente em $32 \%$ respeito ao caso onde foi considerado um único solo em todo o talude (ítem a). No caso do solo saturado este incremento foi de $57 \%$ e no caso da situação não drenada o incremento foi de $84 \%$.

\section{d) Análise da superfície de ruptura fornecida pelo método de Bishop considerando o talude formado por dois solos.}

Neste último caso foi estudado o fator de segurança para dois solos considerando-se a superfície de ruptura crítica fornecida pelo método de Bishop. Na Tabela 5.4 mostram-se os resultados encontrados e os raios correspondentes.

Nas Figuras 5.18 a 5.24, mostram-se graficamente os resultados da Tabela 5.4.

TABELA 5.4 - Fatores de segurança considerando-se a superfície de ruptura fornecida para dois solos.

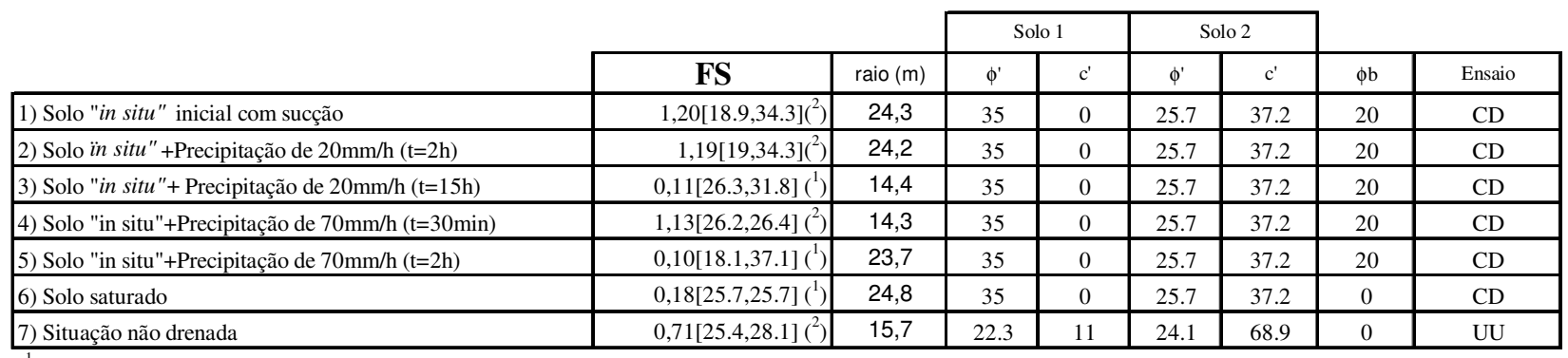

( $\left.{ }^{1}\right)$ Superfície de ruptura crítica menor a superfície crítica assumida, ruptura superficial.

(') Superfície de ruptura pasando acima do solo 2. 


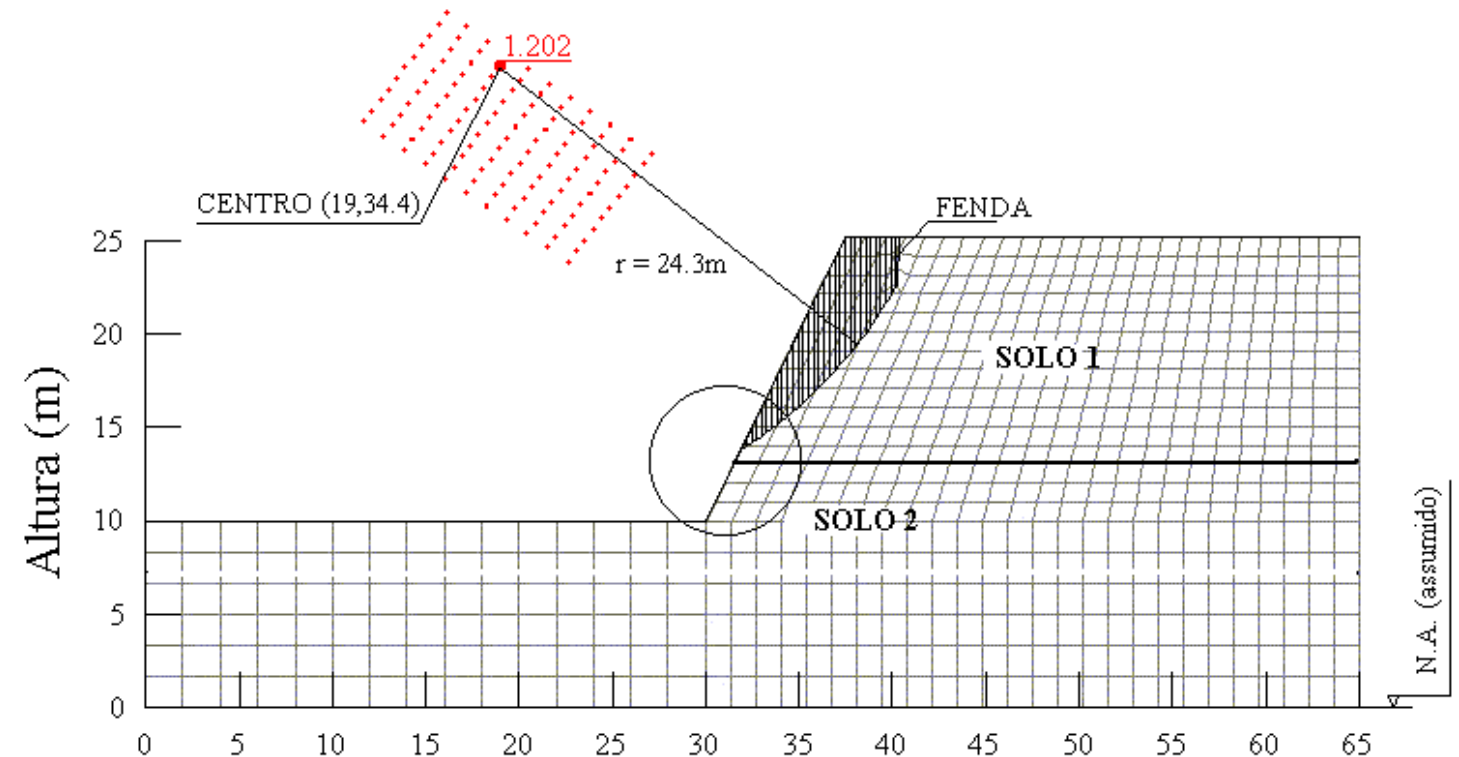

Distância (m)

FIGURA 5.18 - Superfície de ruptura para o caso d-1.

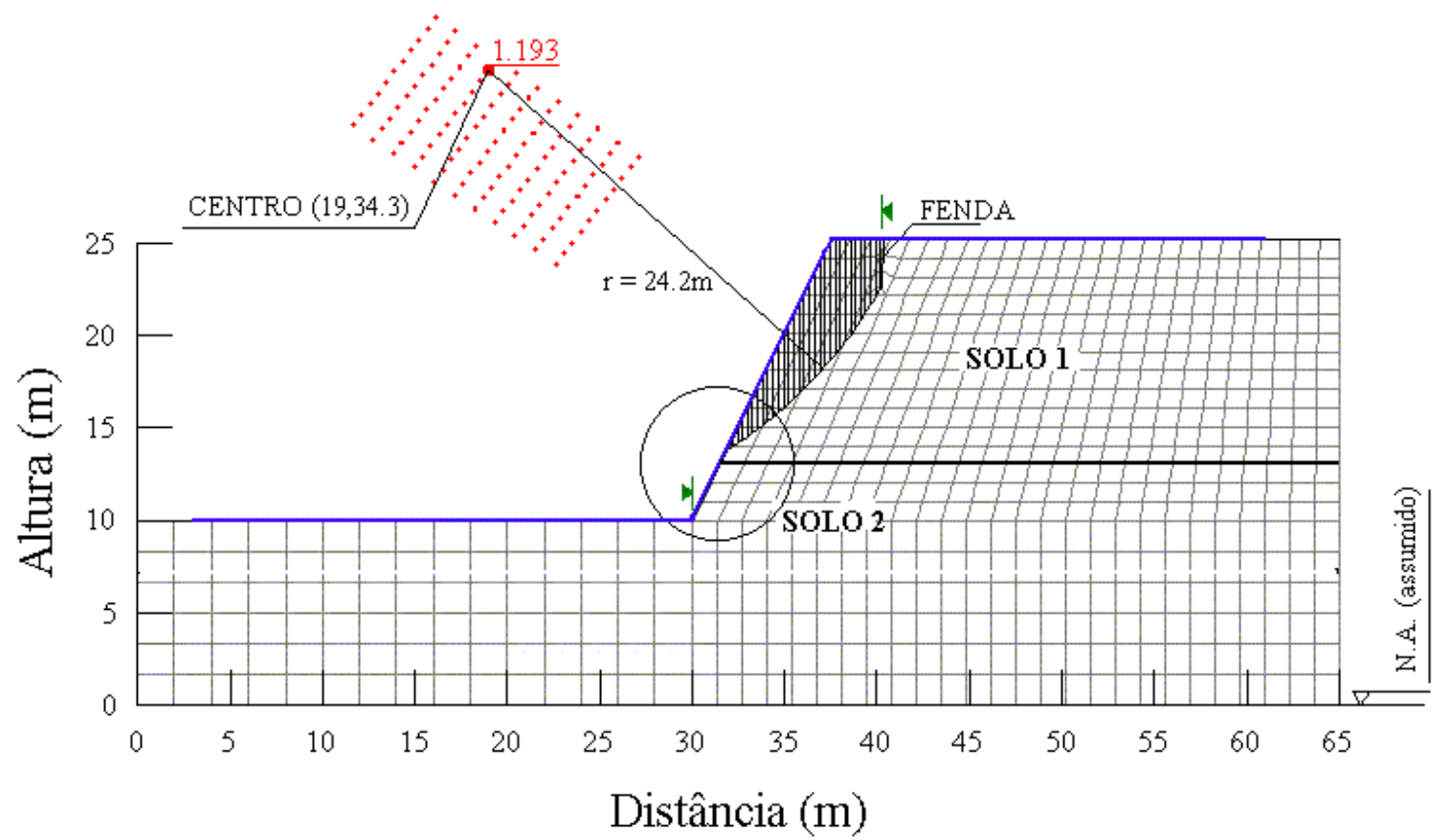

FIGURA 5.19 - Superfície de ruptura para o caso d-2. 


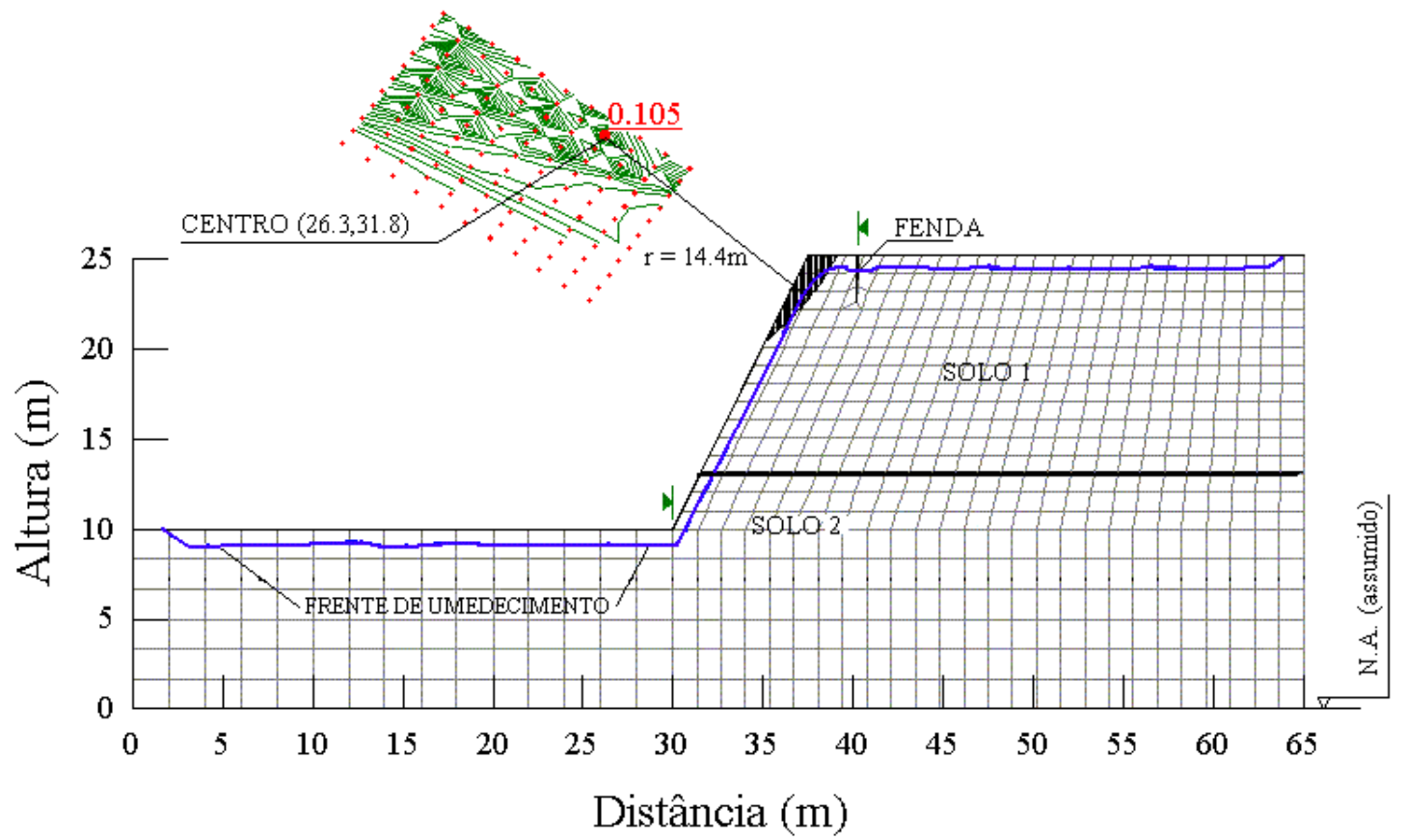

FIGURA 5.20 - Superfície de ruptura para o caso d-3.

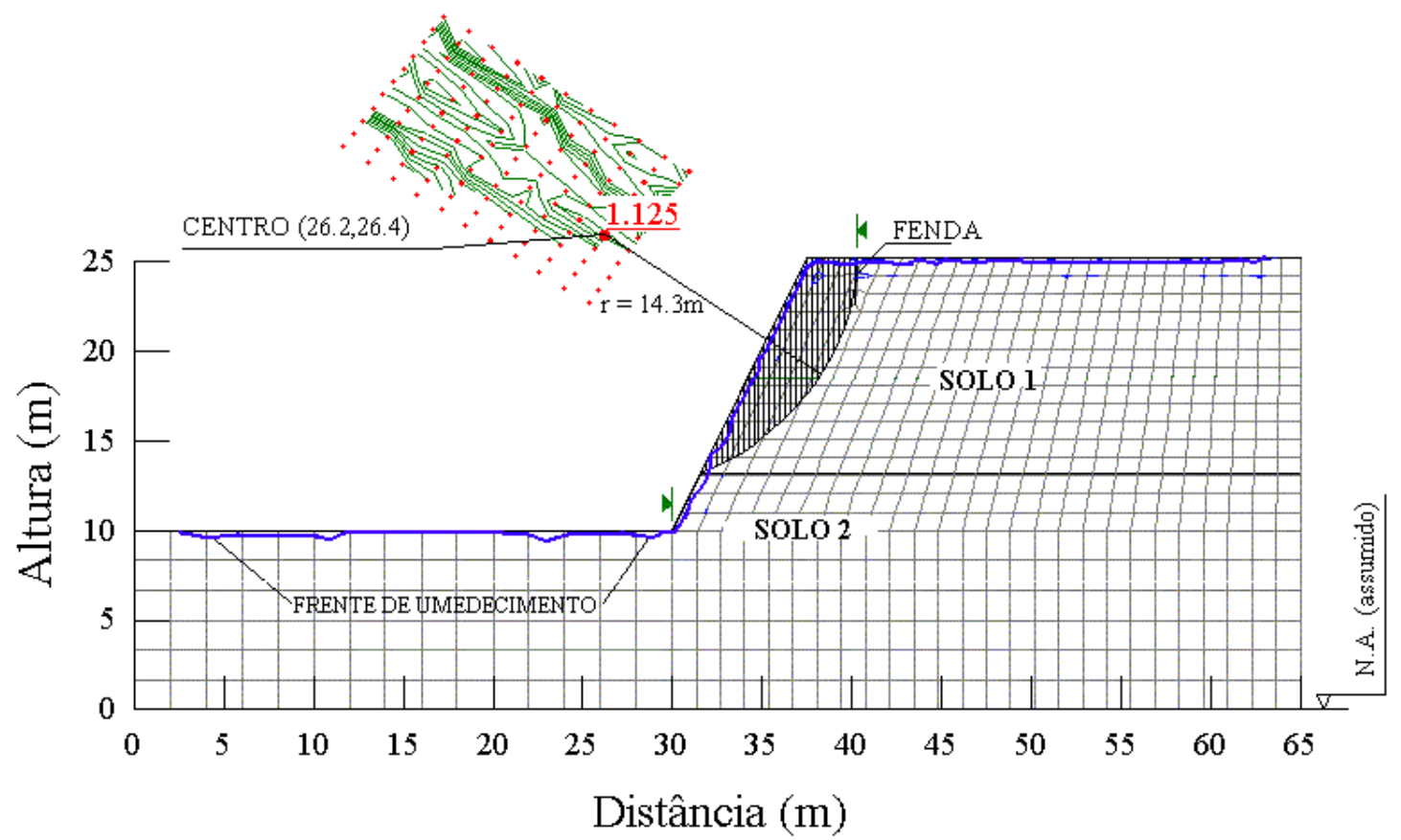

FIGURA 5.21 - Superfície de ruptura para o caso d-4. 


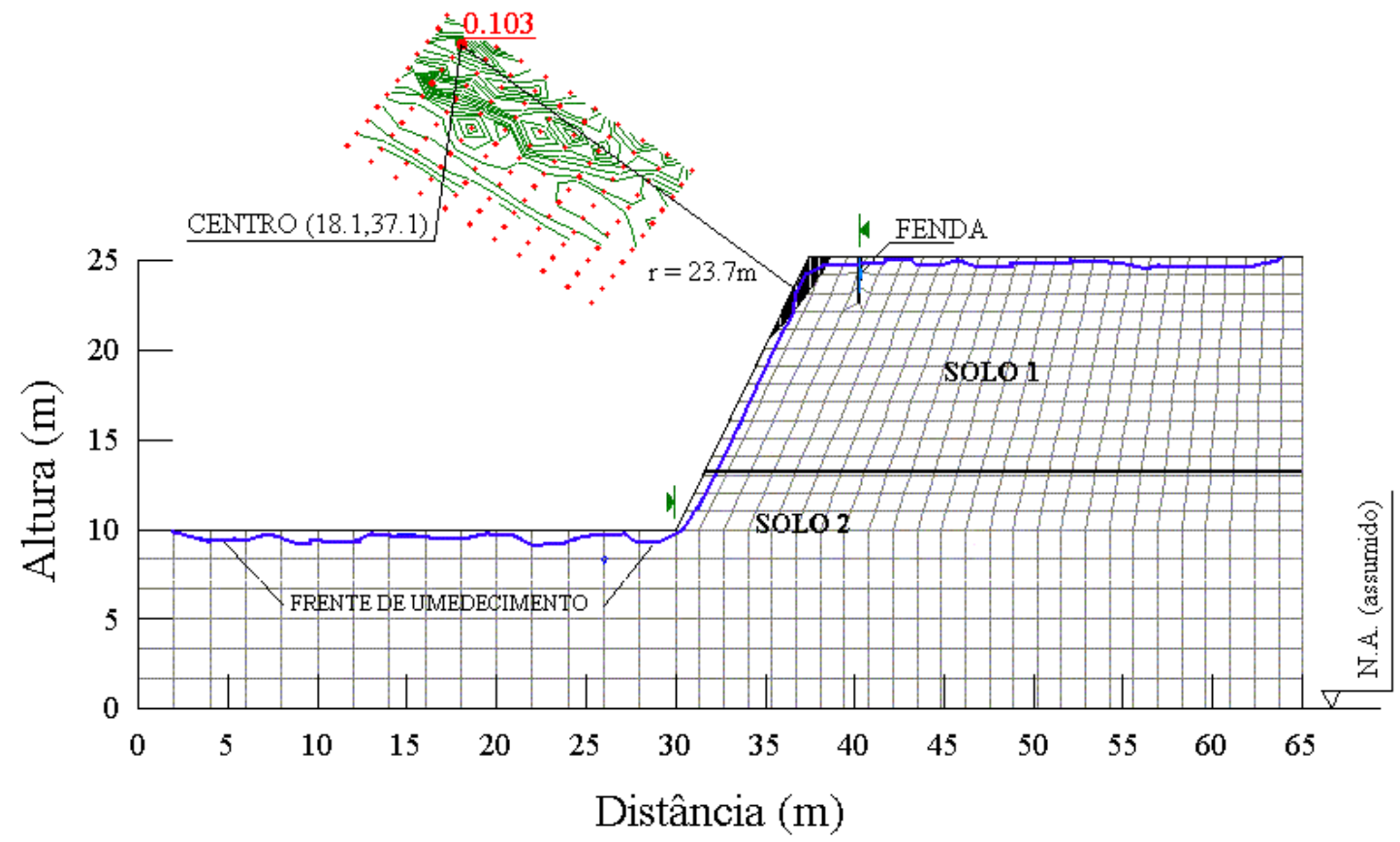

FIGURA 5.22 - Superfície de ruptura para o caso d-5.

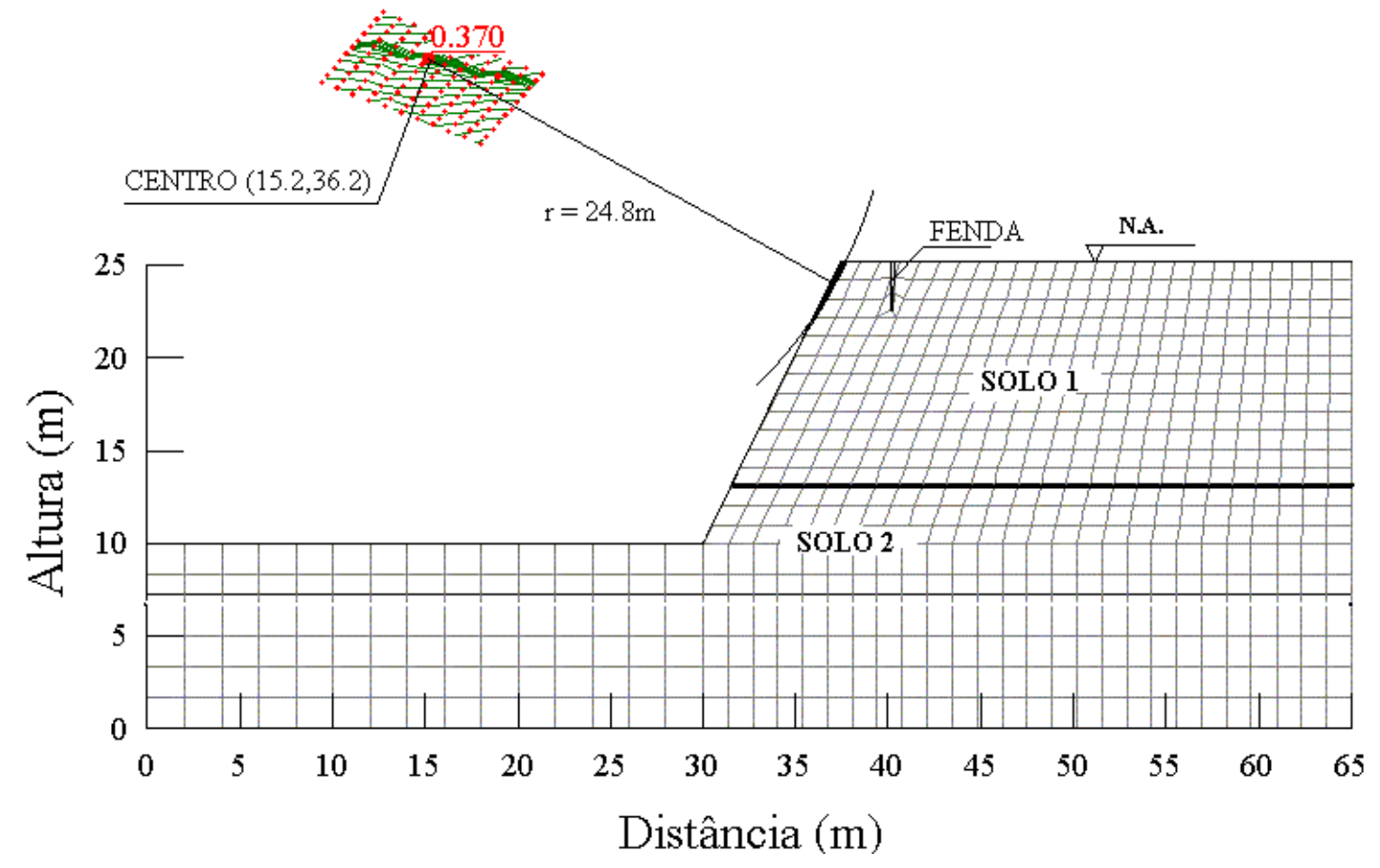

FIGURA 5.23 - Superfície de ruptura para o caso d-6. 


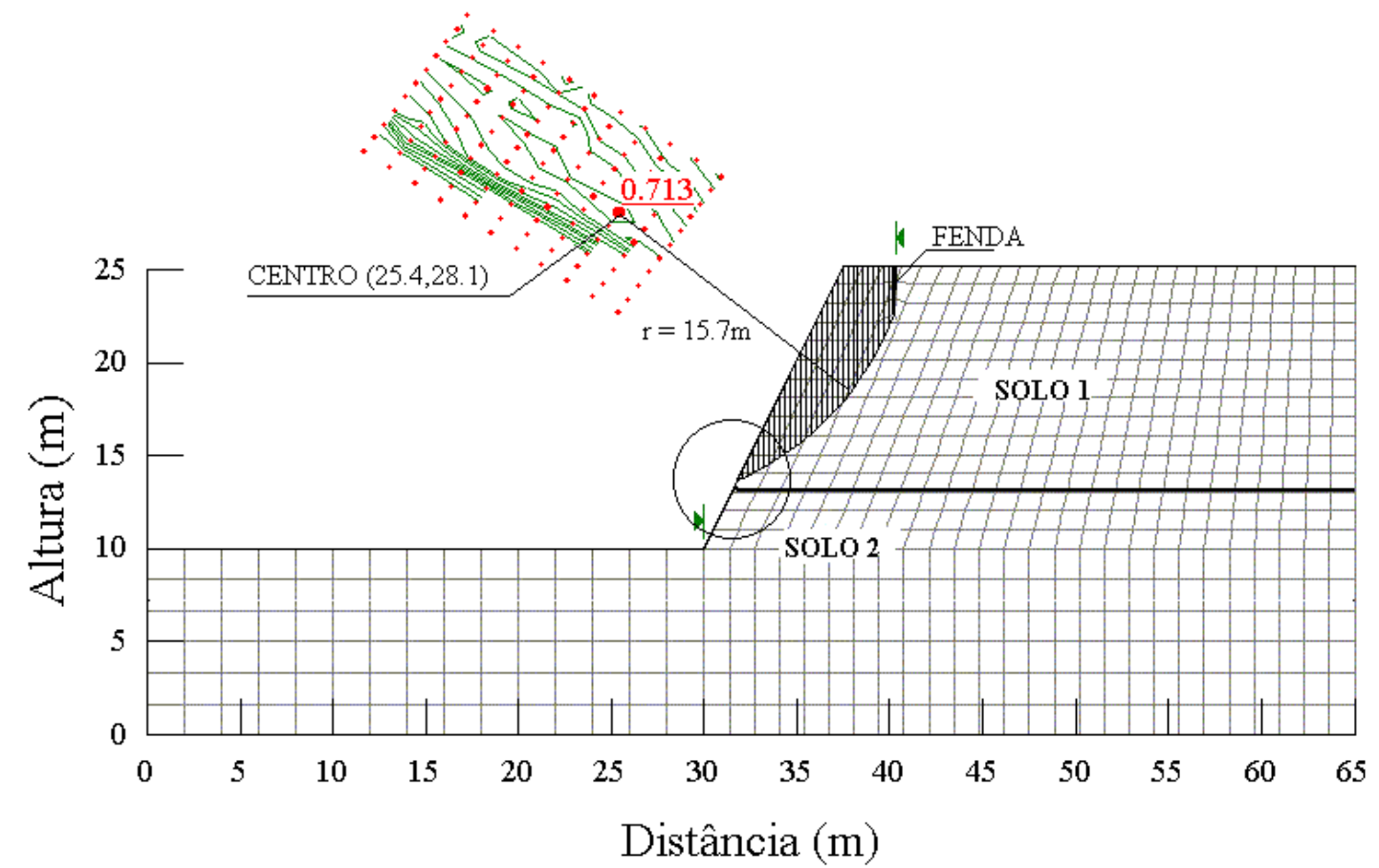

FIGURA 5.24 - Superfície de ruptura para o caso d-7.

Em alguns casos (Figuras 5.18, 5.19, 5.21 e 5.24) a superfície de ruptura localizava-se sobre o solo 2, e apresentaram-se, novamente, rupturas superficiais (Figuras 5.20, 5.22 e $5.23)$.

Quando considerou-se o solo in situ ou $2 \mathrm{~h}$ de uma precipitação de $20 \mathrm{~mm} / \mathrm{h}$, a superfície de ruptura atingiu a base da fenda mas encontrou-se sobre o solo 2 , sendo seu fator de segurança $12 \%$ maior que no caso a) e $16 \%$ menor que no caso c). Quando considerou-se 30min de uma precipitação de $70 \mathrm{~mm} / \mathrm{h}$ o fator de segurança foi $8 \%$ maior que no caso a) e $23 \%$ menor que no caso c) e quando considerou-se a situação não drenada o fator de segurança foi $11 \%$ maior que no caso a) e $60 \%$ menor que no caso c).

Pode-se verificar dos resultados encontrados que a ruptura aconteceu quando o avanço da frente de umedecimento foi menor que $1 \mathrm{~m}$ a contar da superfície, aproximadamente, e que novamente, como viu-se no caso b), apresenta-se rupturas superficiais locais no talude, antes do escorregamento global do mesmo.

\subsection{ANÁLISE DE RUPTURA}

Relembrando-se que a envoltória de resistência utilizada tem a forma seguinte:

$$
\tau=c^{\prime}+\left(\sigma-u_{a}\right) \operatorname{tg} \phi^{\prime}+\left(u_{\mathrm{a}}-u_{w}\right) \operatorname{tg} \phi^{b}
$$


Como o efeito da sucção matricial já está embutida na análise, procurou-se verificar que combinações de coesão efetiva (c') e de ângulo de atrito $\left(\phi^{\prime}\right)$ atendiam a condição do estado crítico de ruptura ( $\mathrm{FS}=1$ ), na superfície de ruptura assumida no ítem 5.3, embora os fatores de segurança sejam próximos de 1.

Para atender a essa condição considerou-se nos cálculos o ângulo $\phi^{\mathrm{b}}=20^{\circ}$, variando-se unicamente os parâmetros c' e $\phi^{\prime}$. No programa SLOPE/W foram ingressadas várias combinações de c' e $\phi^{\prime}$, as características do solo do topo (AI1) e a geometria do talude estudado, considerando-se como condições iniciais de sucção cada envoltória obtida no ítem 5.4, sendo que a pressão de ar $\left(\mathrm{u}_{\mathrm{a}}\right)$ considerou-se nula. Dos fatores de segurança obtidos plotou-se a envoltória do estado crítico de ruptura $(\mathrm{FS}=1)$, para cada condição estudada no ítem 5.4, como pode-se verificar nas Figuras 5.25 e 5.26, onde, as condições iniciais de pressão de água no solo, utilizadas para uma precipitação de $20 \mathrm{~mm} / \mathrm{h}$, foram de 0h (sucção matricial inicial-in situ), 15h, 20h e no estado saturado. No caso da precipitação de $70 \mathrm{~mm} / \mathrm{h}$ estas condições iniciais foram de $0 \mathrm{~h}$ (sucção matricial inicial-in situ), 2h, 3h, 4h e no estado saturado.
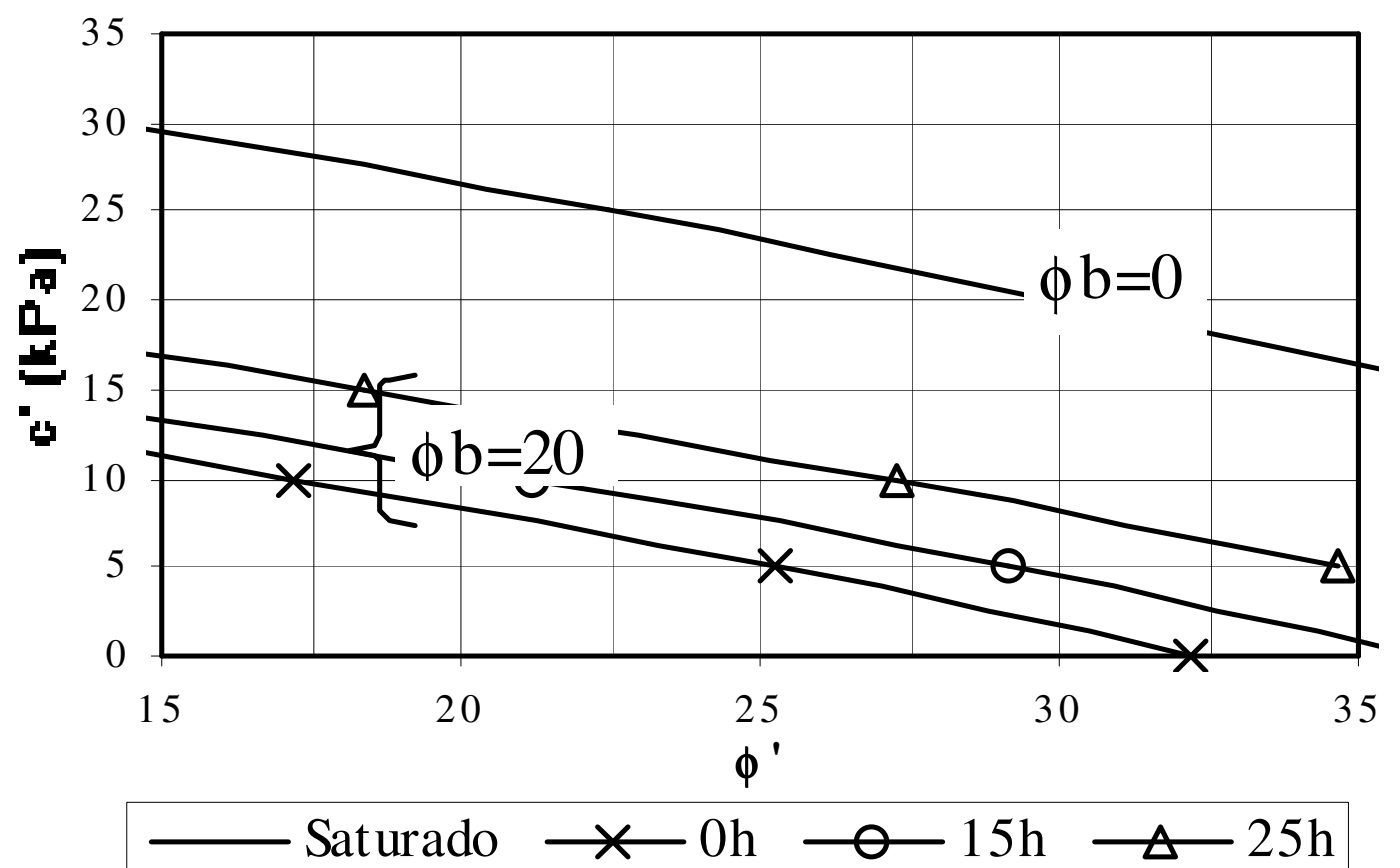

FIGURA 5.25 - Retroanálise considerando-se uma precipitação de 20mm/h e o FS=1, para o talude com $\mathrm{i}=63,9^{\circ}$ e $\mathrm{H}=15,2 \mathrm{~m}$. 


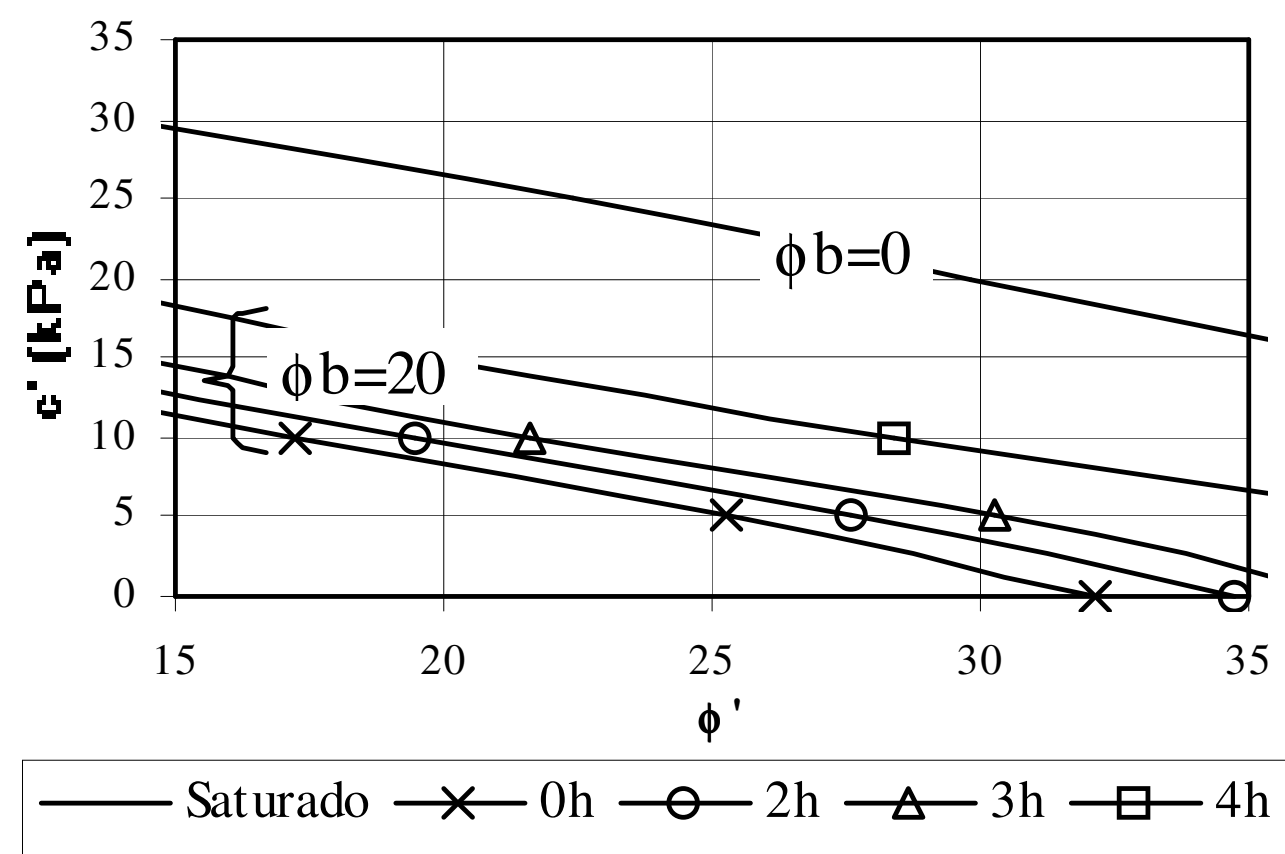

FIGURA 5.26 - Retroanálise considerando-se uma precipitação de 70mm/h e o FS=1, para o talude $\operatorname{com} \mathrm{i}=63,9^{\circ}$ e $\mathrm{H}=15,2 \mathrm{~m}$.

Nas Figuras 5.25 e 5.26 podem-se observar que as curvas críticas (FS=1), considerando-se um tempo de precipitação de $0 \mathrm{~h}$, correspondente ao estado de sucção matricial inicial (in situ), situa-se abaixo da curva correspondente ao solo saturado, e que, conforme aumenta o tempo de precipitação, esta curva de sucção matricial inicial, tende a se aproximar da curva saturada, devido à redução da sucção matricial causada pela infiltração da água de chuva no solo.

\subsection{ANÁLISE DE RUPTURA SEGUNDO OS ÁBACOS DE HOEK (1972)}

Também se efetuou uma análise de ruptura considerando os ábacos de Hoek(1972) e o talude com e sem fenda. Na Figura 5.27 estão as combinações de coesão total (c) e ângulo de atrito $\left(\phi^{\prime}\right)$, que fornecem $\mathrm{FS}=1$, de acordo com o referido método. 


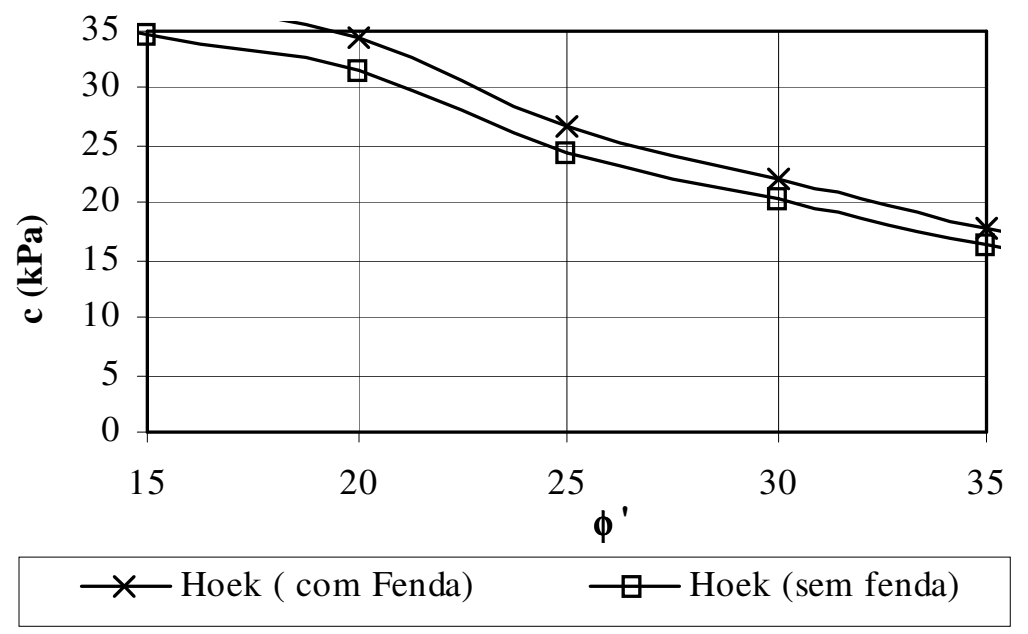

FIGURA 5.27 - Retro-análise segundo ábacos de Hoek(1972).

Observando a Figura 5.1, pode-se assumir uma sucção matricial média de 50kPa ao longo da superfície de ruptura assumida. Com este valor e os parâmetros de resistência do solo encontrados $\left(\phi^{\mathrm{b}}=20^{\circ}, \phi^{\prime}=35\right.$ e $\left.\mathrm{c}^{\prime}=0\right)$, pode-se determinar uma coesão média total de c=18,2kPa. Plotando-se este valor e o ângulo de atrito na Figura 5.27, pode-se verificar que o fator de segurança é próximo de 1 . Se fossem plotados os valores de coesão e ângulo de atrito, considerando o solo saturado ( $c^{\prime}=0$ e $\left.\phi^{\prime}=35\right)$, o fator de segurança no método de Hoek (1972), seria muito menor que 1 , daí a importância da determinação da sucção matricial no campo.

\subsection{VARIAÇÃO DO FATOR DE SEGURANÇA COM O TEMPO DE PRECIPITAÇÃO, VÁlIDO PARA TALUDE HOMOGÊNEO COM i=63,9e $\mathrm{H}=\mathbf{1 5 , 2 2 \mathrm { m }}$}

Em seguida, nas Figuras 5.28 e 5.29, considerando-se a superfície de ruptura assumida no ítem 5.3 e a geometria do talude estudado, procurou-se verificar a variação do fator de segurança, com relação a diferentes tempos de precipitação, com o propósito de fornecer exemplos de ábacos que possam ser construídos em projetos de taludes com características semelhantes. Nesta avaliação, fixou-se $\phi_{b}=20^{\circ}$, variou-se $\phi$ ' e utilizou-se c' $=0 \mathrm{kPa}$ e c' $=20 \mathrm{kPa}$ para precipitações de $20 \mathrm{~mm} / \mathrm{h}$ e $70 \mathrm{~mm} / \mathrm{h}$, respectivamente. 


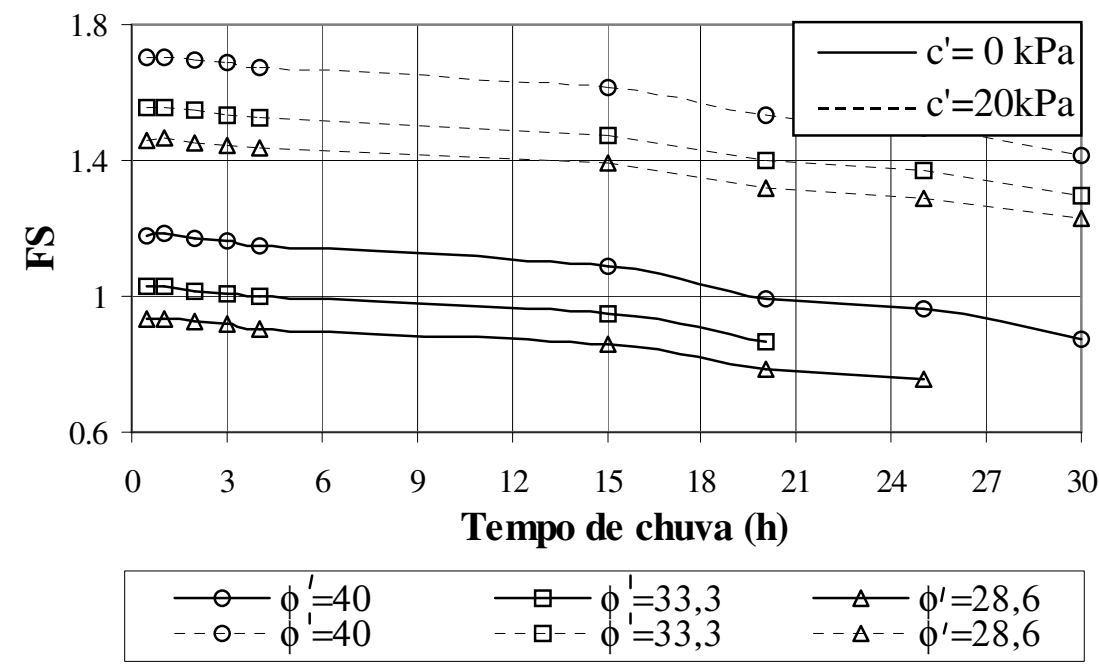

FIGURA 5.28 - Variação do fator de segurança com o tempo de precipitação para $\phi^{\mathrm{b}}=20$ e precipitação de $20 \mathrm{~mm} / \mathrm{h}$.

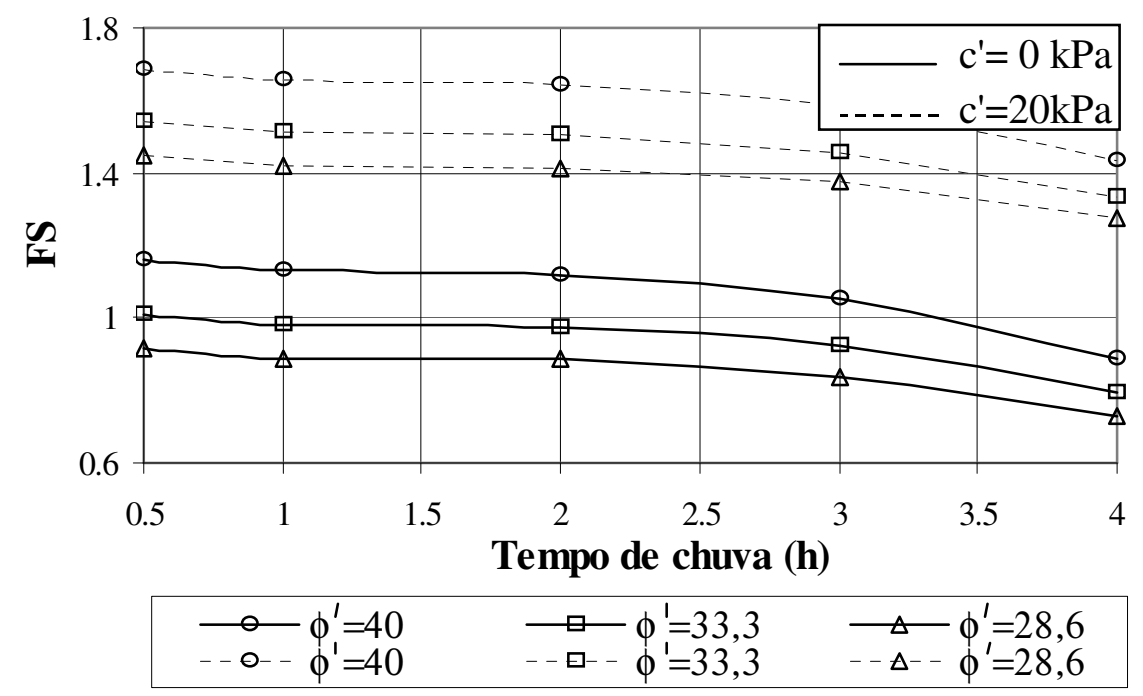

FIGURA 5.29 - Variação do fator de segurança com o tempo de precipitação para $\phi^{\mathrm{b}}=20$ e precipitação de $70 \mathrm{~mm} / \mathrm{h}$.

Como exemplo da utilização dos ábacos 5.26 e 5.29 (para uma precipitação de $70 \mathrm{~mm} / \mathrm{h}$ ), observa-se na Figura 4.15, os resultados de um ensaio triaxial com controle de sucção matricial, onde para uma sucção matricial de $50 \mathrm{kPa}$, obteve-se uma coesão devida a sucção matricial (c) de $17 \mathrm{kPa}$, um ângulo de atrito ( $\left.\phi^{\prime}\right)$ de $34,7^{\circ}$, uma coesão efetiva (c') de $0 \mathrm{kPa}$ (obtida do ensaio $\mathrm{CD}$, saturado por contrapressão) e um ângulo de sucção $\left(\phi^{\mathrm{b}}\right)$ de $20^{\circ}$ (Figura 4.17). Plotando-se agora estes valores na Figura 5.26, verifica-se que o ponto se situa sobre a curva de sucção inicial "in situ" ( $\phi^{\mathrm{b}}=20$ e t=0h), ou seja o fator de segurança é maior que 1. Ademais, verifica-se também na Figura 5.29, que o tempo crítico de ruptura é próximo a $3 \mathrm{~h}$ para uma precipitação de $70 \mathrm{~mm} / \mathrm{h}$. 


\section{CONCLUSÕES}

A partir de um escorregamento de talude em solo não saturado, fizeram-se várias simulações com o intuito de tentar explicar a ruptura sob a ótica da Mecânica dos Solos não saturados.

O talude estudado é composto de uma areia argilo-siltosa marrom de origem residual, relativamente homogêneo e não saturado.

Pode-se verificar que o solo em questão apresenta condutividade hidráulica saturada da ordem de $10^{-4} \mathrm{~cm} / \mathrm{s}$, o que corresponde à permeabilidade de areias finas. A função condutividade hidráulica, determinada a partir de ensaios de campo, também mostrou-se compatível com valores de areia fina, com os valores de condutividade decrescendo significativamente para valores de sucção matricial superiores a $30 \mathrm{kPa}$.

Com relação à resistência ao cisalhamento, observou-se que esta cresce linearmente com a sucção matricial até valores cerca de $100 \mathrm{kPa}$, quando então permanece praticamente constante. A relação $\phi^{\mathrm{b}} / \phi$ ' (ângulo de atrito em relação à sucção matricial / ângulo de atrito drenado) obtida foi de 0,57 .

A partir de medidas de sucção matricial "in situ" e da utilização do programa SEEP/W, buscou-se determinar o perfil de sucção ocorrente no talude. Os máximos valores determinados nessa situação foram considerados como ponto de partida para as análises subsequentes.

Verificou-se que o avanço da frente de infiltração é progressiva. Por exemplo, uma chuva de $20 \mathrm{~mm} / \mathrm{h}$ faz com que a frente de infiltração atinja $0,8 \mathrm{~m}$ a contar da superfície, após 15 horas e 1,42m após $25 \mathrm{~h}$. Já para $70 \mathrm{~mm} / \mathrm{h}$ de precipitação esses valores são $0,75 \mathrm{~m}$ para $3 \mathrm{~h}$ e $0,92 \mathrm{~m}$ para $4 \mathrm{~h}$.

Para o perfil de sucção matricial inicial e os parâmetros de resistência correspondentes ao solo não saturado obtidos em laboratório, verificou-se que o fator de segurança, para a superfície de ruptura delimitada em campo, é ligeiramente maior que a unidade. No entanto, quando se considerou o solo saturado e os parâmetros de resistência correspondentes o fator de segurança foi bem menor que a unidade, o que sugere que o talude deve ter escorregado 
em estado não saturado. $\mathrm{O}$ fator de segurança decresce e se aproxima de 1,0 quando uma precipitação de $20 \mathrm{~mm} / \mathrm{h}$ dura 15 horas ou outra de $70 \mathrm{~mm} / \mathrm{h}$ dura 2,5 horas, aproximadamente, sendo que o avanço da frente de umedecimento nestes casos críticos foi menor que $1 \mathrm{~m}$ de profundidade.

Interessante é notar que o avanço da frente de umedecimento, ao provocar a saturação do solo, pode justificar os pequenos escorregamentos superficiais observados em toda a área como viu-se na Figura 3.5.

Quando consideraram-se dois solos compondo o talude, os fatores de segurança encontrados para a superfície de ruptura assumida no trabalho aumentaram aproximadamente em $30 \%$, em relação ao fator de segurança obtido para o talude composto por um único solo.

Considerando-se a distribuição da sucção matricial do solo, para diversas precipitações e tempos de precipitação, apresentaram-se diversos ábacos de análise de ruptura, onde verificou-se a importância da sucção matricial.

Cabe ressaltar a importância da redução da sucção matricial, causada pela infiltração da água de chuva, na resistência ao cisalhamento dos solos em taludes tropicais, os quais escorregam principalmente por causa dessa redução.

Devido a ausência de um estudo detalhado de vários escorregamentos e de uma análise estatística dos dados coletados, que no caso do projeto foram poucos e correspondentes a um único escorregamento, os ábacos apresentados no presente trabalho são de aplicação unicamente na região estudada. Portanto é importante realizar mais estudos de retro-análise considerando o efeito da sucção matricial. Estes estudos permitirão elaborar ábacos de retro-análise como os apresentados por Hoek (1971), mas considerando-se o efeito da sucção matricial do solo não embutida na retro-análise.

Recomenda-se finalmente, utilizar o presente trabalho só como referência para futuros estudos de retro-análise de ruptura de taludes em solo não saturados, especificamente em taludes de origem residual, típico de climas tropicais, como o Brasil. 


\section{ANEXOS}


ANEXO A - SONDAGENS S1 e S2. 
FOLHA DE SONDAGEM

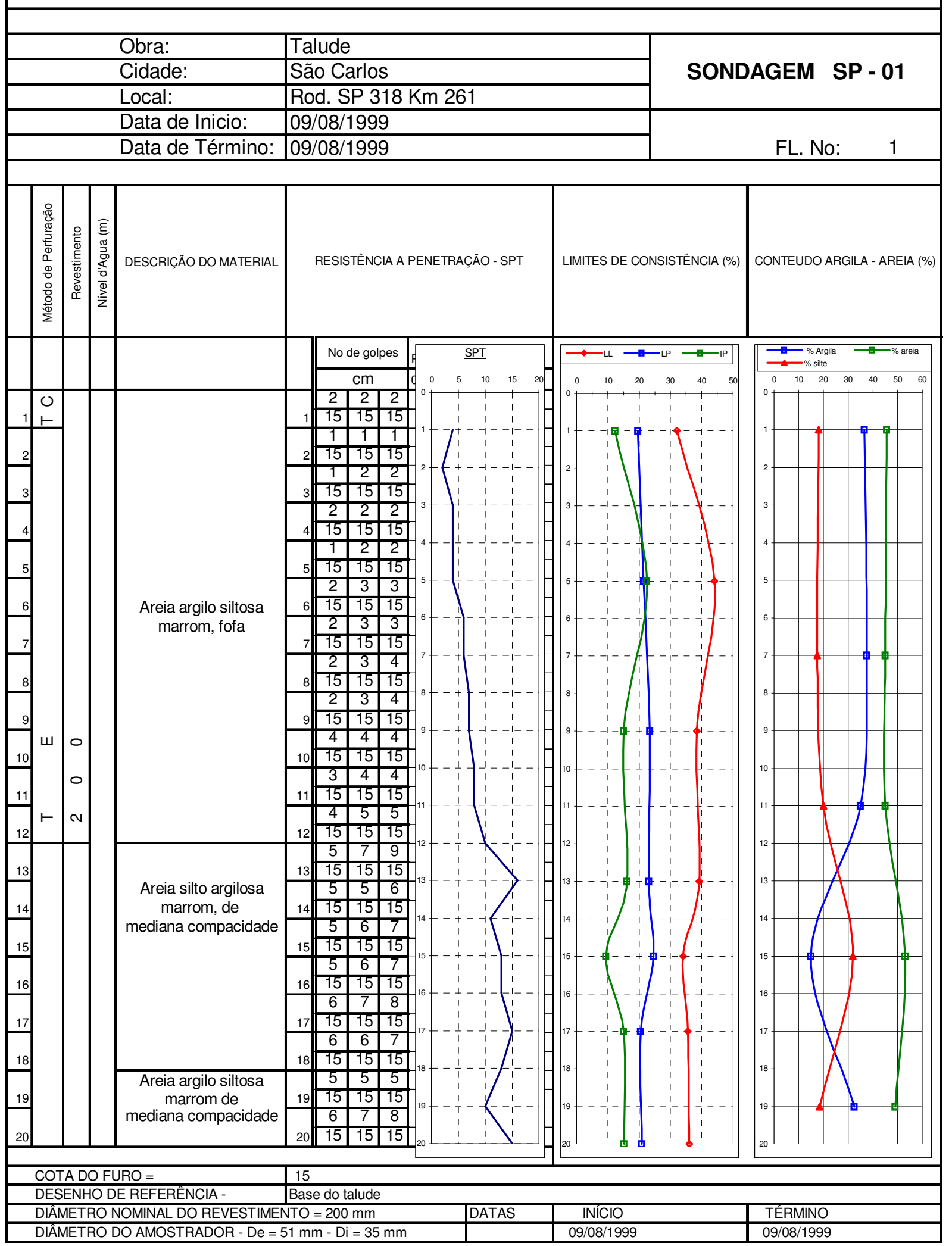




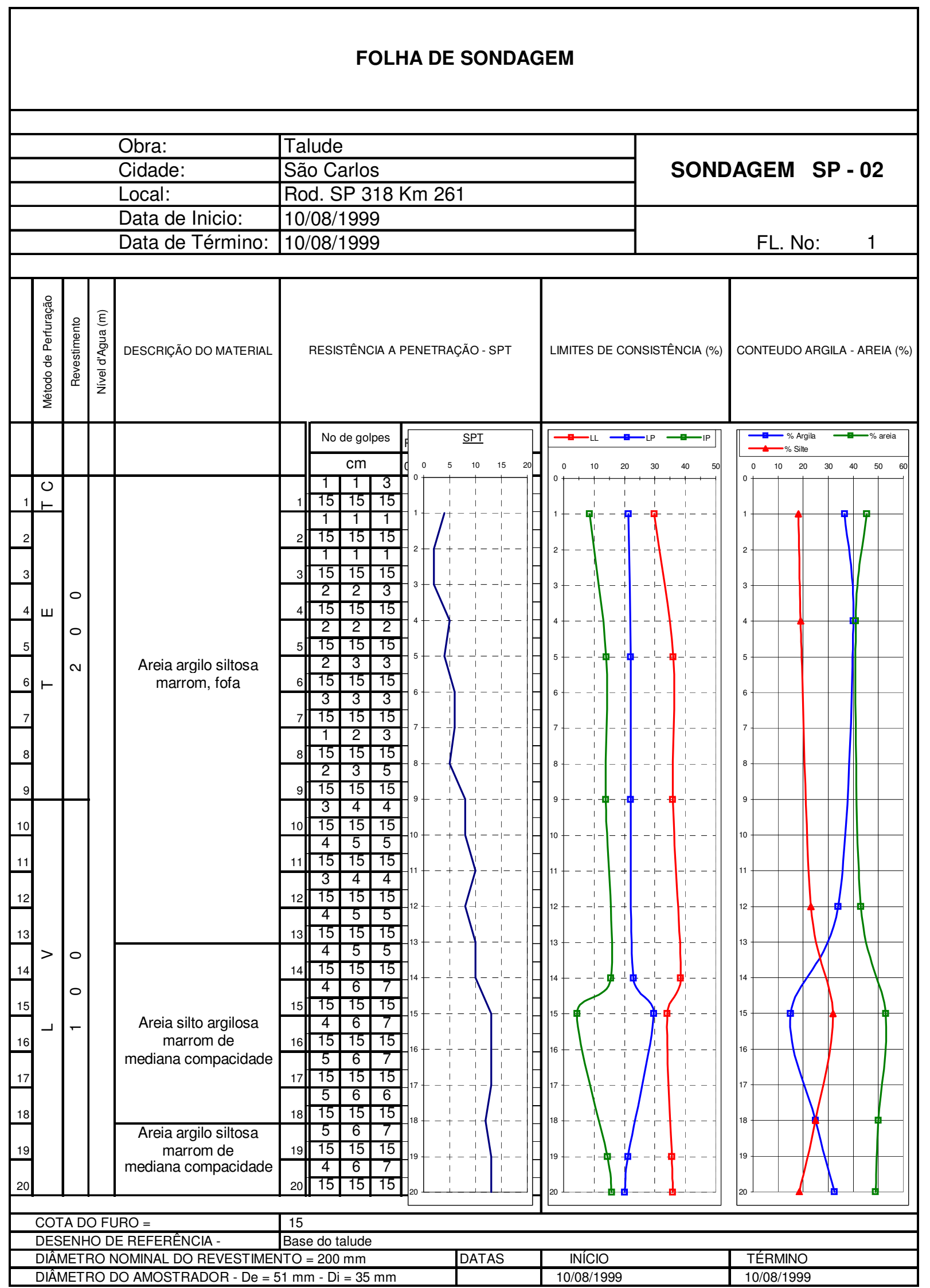


ANEXO B - ENSAIOS COM PAPEL FILTRO. 
TABELA B1 - Ensaio de papel filtro, local AI1.

\begin{tabular}{|c|c|c|c|c|c|}
\hline & \multicolumn{2}{|c|}{ Corpo de prova } & Papel filtro & \multicolumn{2}{c|}{ Sucção obtida } \\
\hline CP & w $(\%)$ & $\phi(\mathrm{cm} 3 / \mathrm{cm} 3)$ & w $(\%)$ & $(\mathrm{cm})$ & $(\mathrm{kPa})$ \\
\hline 1 & 40.31 & 0.534 & 252.74 & 1.00 & 0.10 \\
\hline 2 & 30.50 & 0.404 & 147.53 & 26.32 & 2.63 \\
\hline 3 & 27.93 & 0.370 & 141.77 & 31.49 & 3.15 \\
\hline 4 & 29.37 & 0.389 & 140.79 & 32.46 & 3.25 \\
\hline 5 & 29.37 & 0.389 & 140.26 & 33.00 & 3.30 \\
\hline 6 & 28.38 & 0.376 & 139.38 & 33.91 & 3.39 \\
\hline 7 & 27.93 & 0.370 & 139.10 & 34.21 & 3.42 \\
\hline 8 & 27.64 & 0.366 & 136.16 & 37.48 & 3.75 \\
\hline 9 & 28.38 & 0.376 & 135.58 & 38.17 & 3.82 \\
\hline 10 & 27.64 & 0.366 & 134.76 & 39.15 & 3.92 \\
\hline 11 & 29.12 & 0.386 & 134.72 & 39.20 & 3.92 \\
\hline 12 & 29.12 & 0.386 & 132.94 & 41.43 & 4.14 \\
\hline 13 & 25.24 & 0.334 & 132.38 & 42.16 & 4.22 \\
\hline 14 & 25.55 & 0.338 & 131.74 & 43.00 & 4.30 \\
\hline 15 & 25.55 & 0.338 & 130.57 & 44.60 & 4.46 \\
\hline 16 & 25.24 & 0.334 & 125.32 & 52.50 & 5.25 \\
\hline 17 & 19.24 & 0.255 & 50.65 & 240.59 & 24.06 \\
\hline 18 & 19.24 & 0.255 & 50.00 & 270.59 & 27.06 \\
\hline 19 & 16.82 & 0.223 & 45.45 & 611.57 & 61.16 \\
\hline 20 & 16.82 & 0.223 & 45.39 & 618.19 & 61.82 \\
\hline 21 & 13.01 & 0.172 & 15.34 & 135523.00 & 13552.30 \\
\hline 22 & 13.01 & 0.172 & 15.16 & 139970.00 & 13997.00 \\
\hline
\end{tabular}


TABELA B2 - Ensaio de papel filtro, local AI2.

\begin{tabular}{|c|c|c|c|c|c|}
\hline & \multicolumn{2}{|c|}{ Corpo de prova } & Papel filtro & \multicolumn{2}{c|}{ Sucção obtida } \\
\hline CP & w $(\%)$ & $\phi(\mathrm{cm} 3 / \mathrm{cm} 3)$ & $\mathrm{w}(\%)$ & $(\mathrm{cm})$ & $(\mathrm{kPa})$ \\
\hline 1 & 30.30 & 0.467 & 252.74 & 1.00 & 0.10 \\
\hline 2 & 26.23 & 0.404 & 146.23 & 27.41 & 2.74 \\
\hline 3 & 26.23 & 0.404 & 145.79 & 27.79 & 2.78 \\
\hline 4 & 24.99 & 0.385 & 132.45 & 42.07 & 4.21 \\
\hline 5 & 24.99 & 0.385 & 129.89 & 45.55 & 4.56 \\
\hline 6 & 25.56 & 0.394 & 128.35 & 47.79 & 4.78 \\
\hline 7 & 25.56 & 0.394 & 126.78 & 50.17 & 5.02 \\
\hline 8 & 24.18 & 0.372 & 115.22 & 71.87 & 7.19 \\
\hline 9 & 23.12 & 0.356 & 112.92 & 77.19 & 7.72 \\
\hline 10 & 23.12 & 0.356 & 111.92 & 79.63 & 7.96 \\
\hline 11 & 24.21 & 0.373 & 109.28 & 86.44 & 8.64 \\
\hline 12 & 24.21 & 0.373 & 108.80 & 87.74 & 8.77 \\
\hline 13 & 21.16 & 0.326 & 50.28 & 257.38 & 25.74 \\
\hline 14 & 20.72 & 0.319 & 50.25 & 258.42 & 25.84 \\
\hline 15 & 21.16 & 0.326 & 50.17 & 262.47 & 26.25 \\
\hline 16 & 20.72 & 0.319 & 50.08 & 266.74 & 26.67 \\
\hline 17 & 20.82 & 0.321 & 50.05 & 267.99 & 26.80 \\
\hline 18 & 20.82 & 0.321 & 49.89 & 275.68 & 27.57 \\
\hline 19 & 19.90 & 0.306 & 49.11 & 317.37 & 31.74 \\
\hline 20 & 19.90 & 0.306 & 48.85 & 332.62 & 33.26 \\
\hline 21 & 19.74 & 0.304 & 47.67 & 410.65 & 41.07 \\
\hline 22 & 19.74 & 0.304 & 47.53 & 421.39 & 42.14 \\
\hline 23 & 15.05 & 0.232 & 22.82 & 35425.99 & 3542.60 \\
\hline 24 & 15.05 & 0.232 & 21.75 & 42921.51 & 4292.15 \\
\hline
\end{tabular}


TABELA B3 - Ensaio de papel filtro, local AI3.

\begin{tabular}{|c|c|c|c|c|c|}
\hline & \multicolumn{2}{|c|}{ Corpo de prova } & Papel filtro & \multicolumn{2}{c|}{ Sucção obtida } \\
\hline CP & w $(\%)$ & $\phi(\mathrm{cm} 3 / \mathrm{cm} 3)$ & $\mathrm{w}(\%)$ & $(\mathrm{cm})$ & $(\mathrm{kPa})$ \\
\hline 1 & 39.66 & 0.524 & 252.74 & 1.00 & 0.10 \\
\hline 2 & 30.76 & 0.406 & 156.05 & 20.20 & 2.02 \\
\hline 3 & 28.80 & 0.380 & 154.95 & 20.90 & 2.09 \\
\hline 4 & 25.70 & 0.339 & 151.04 & 23.60 & 2.36 \\
\hline 5 & 28.80 & 0.380 & 146.71 & 27.00 & 2.70 \\
\hline 6 & 25.70 & 0.339 & 146.71 & 27.00 & 2.70 \\
\hline 7 & 30.76 & 0.406 & 146.01 & 27.60 & 2.76 \\
\hline 8 & 25.22 & 0.333 & 145.10 & 28.39 & 2.84 \\
\hline 9 & 26.69 & 0.352 & 144.41 & 29.00 & 2.90 \\
\hline 10 & 23.89 & 0.315 & 142.47 & 30.81 & 3.08 \\
\hline 11 & 23.89 & 0.315 & 142.18 & 31.09 & 3.11 \\
\hline 12 & 26.83 & 0.354 & 141.05 & 32.20 & 3.22 \\
\hline 13 & 26.65 & 0.352 & 141.05 & 32.20 & 3.22 \\
\hline 14 & 23.64 & 0.312 & 140.42 & 32.83 & 3.28 \\
\hline 15 & 26.83 & 0.354 & 138.00 & 35.40 & 3.54 \\
\hline 16 & 26.65 & 0.352 & 136.58 & 37.00 & 3.70 \\
\hline 17 & 25.22 & 0.333 & 135.19 & 38.63 & 3.86 \\
\hline 18 & 26.69 & 0.352 & 134.07 & 40.00 & 4.00 \\
\hline 19 & 23.60 & 0.312 & 131.00 & 44.00 & 4.40 \\
\hline 20 & 23.64 & 0.312 & 130.87 & 44.18 & 4.42 \\
\hline 21 & 23.60 & 0.312 & 128.20 & 48.00 & 4.80 \\
\hline 22 & 23.60 & 0.312 & 126.00 & 51.40 & 5.14 \\
\hline 23 & 23.60 & 0.312 & 125.02 & 53.00 & 5.30 \\
\hline 24 & 23.60 & 0.312 & 123.25 & 56.00 & 5.60 \\
\hline 25 & 22.40 & 0.296 & 121.03 & 60.00 & 6.00 \\
\hline 26 & 22.40 & 0.296 & 118.95 & 64.00 & 6.40 \\
\hline 27 & 22.26 & 0.294 & 117.96 & 66.00 & 6.60 \\
\hline 28 & 22.26 & 0.294 & 116.02 & 70.10 & 7.01 \\
\hline 29 & 17.29 & 0.228 & 45.91 & 563.00 & 56.30 \\
\hline 30 & 17.29 & 0.228 & 45.56 & 600.00 & 60.00 \\
\hline 31 & 11.96 & 0.158 & 16.00 & 120390.00 & 12039.00 \\
\hline 32 & 11.96 & 0.158 & 15.00 & 144040.00 & 14404.00 \\
\hline & & & & & \\
\hline
\end{tabular}


ANEXO C - ENSAIOS COM A CÂMARA DE PRESSÃO. 
a) Local de amostragem AI1

TABELA C1 - Condições iniciais antes do ensaio com a câmara de pressão, local AI1

\begin{tabular}{|c|c|c|c|c|c|c|}
\hline CP & Massa(g) & wo(\%) & $\boldsymbol{\rho}$ & $\boldsymbol{\rho}_{\mathbf{s}}$ & $\boldsymbol{\rho}_{\mathbf{d}}$ & $\mathbf{e}$ \\
\hline $\mathrm{T} 10$ & 34,6 & 21,3 & 1,25 & 2,9 & 1,03 & 1,80 \\
\hline $\mathrm{T} 11$ & 33,9 & 21,3 & 1,53 & 2,9 & 1,26 & 1,28 \\
\hline $\mathrm{T} 12$ & 32,3 & 21,0 & 1,14 & 2,9 & 0,95 & 2,06 \\
\hline
\end{tabular}

TABELA C2 - Resultados obtidos, local AI1.

\begin{tabular}{|c|c|c|c|c|c|c|c|}
\hline $\begin{array}{c}\text { Sucção } \\
{[\mathbf{k P a}]}\end{array}$ & \multicolumn{3}{|c|}{ Massas [g] } & \multicolumn{3}{|c|}{$\mathbf{w}[\%]$} & \multirow{2}{*}{$\mathbf{w}_{\text {media }}$ [\%] } \\
\hline & $\mathbf{T 1 0}$ & $\mathbf{T 1 1}$ & $\mathbf{T 1 2}$ & $\mathbf{T 1 0}$ & $\mathbf{T 1 1}$ & $\mathbf{T 1 2}$ & \\
\hline 5 & 35,70 & 35,20 & 33,19 & 25,14 & 25,87 & 24,35 & 25,12 \\
\hline 10 & 34,90 & 34,38 & 32,15 & 22,33 & 22,94 & 20,46 & 21,91 \\
\hline 50 & 33,63 & 33,08 & 30,85 & 17,88 & 18,28 & 15,56 & 17,24 \\
\hline 100 & 33,27 & 32,73 & 30,58 & 16,62 & 17,02 & 14,55 & 16,06 \\
\hline 300 & 33,07 & 32,52 & 30,42 & 15,94 & 16,28 & 13,95 & 15,39 \\
\hline 400 & 32,84 & 32,29 & 30,21 & 15,11 & 15,44 & 13,17 & 14,57 \\
\hline
\end{tabular}

b) Local de amostragem AI3

TABELA C3 - Condições iniciais antes do ensaio com a câmara de pressão, local AI3

\begin{tabular}{|c|c|c|c|c|}
\hline wo(\%) & $\boldsymbol{\rho}$ & $\boldsymbol{\rho s}$ & $\mathbf{\rho d}$ & $\mathbf{e}$ \\
\hline 21,24 & 1,50 & 2,90 & 1,24 & 1,34 \\
\hline
\end{tabular}

TABELA C4 - Resultados obtidos, local AI3.

\begin{tabular}{|c|c|c|c|c|c|c|c|}
\hline \multirow{2}{*}{$\begin{array}{c}\text { Sucção } \\
{[\mathbf{k P a}]}\end{array}$} & \multicolumn{3}{|c|}{ Massas [g] } & \multicolumn{3}{|c|}{$\mathbf{w}[\%]$} & \multirow{2}{*}{ (\%) } \\
\cline { 2 - 7 } & $\mathbf{T 2}$ & $\mathbf{T 6}$ & $\mathbf{T 1 3}$ & $\mathbf{T 2}$ & $\mathbf{T 6}$ & $\mathbf{T 1 3}$ & \\
\hline 10 & 32,94 & 32,75 & 32,47 & 21,91 & 19,98 & 16,62 & 19,50 \\
\hline 50 & 32,58 & 32,43 & 32,08 & 20,57 & 18,80 & 15,21 & 18,19 \\
\hline 100 & 32,00 & 31,82 & 31,50 & 18,43 & 16,59 & 13,15 & 16,06 \\
\hline 300 & 31,82 & 31,38 & 31,25 & 17,77 & 14,95 & 12,26 & 14,99 \\
\hline 400 & 31,56 & 31,14 & 31,01 & 16,8 & 14,08 & 11,39 & 14,09 \\
\hline
\end{tabular}


ANEXO D - PLANILHAS DO ENSAIO DE CAMPO COM O PERMEÂMETRO DE GUELPH. 


\section{a) Local de amostragem AI1}

Data:

Maio / 1999

\begin{tabular}{|ll|r|}
\hline Ambos reservatórios $(\mathrm{X})$ & $\mathrm{cm}^{2}$ & 35.39 \\
\hline Reservatório interno $(\mathrm{Y})$ & $\mathrm{cm}^{2}$ & 2.14 \\
\hline
\end{tabular}

Leituras para $\circ 1^{\circ}$ estágio $\left(\mathrm{H}_{1}\right)$ de $5 \mathrm{~cm}$.

\begin{tabular}{|c|c|c|c|c|c|c|c|c|}
\hline$\stackrel{\circ}{z}$ & 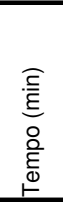 & 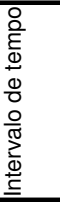 & . & 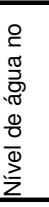 & & 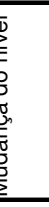 & & 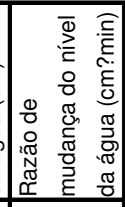 \\
\hline 1 & 0 & $\overline{1}$ & & 4 & & - & & \\
\hline 2 & 1 & $\overline{1}$ & & 6, & & 1,2 & & \\
\hline 3 & 2 & 1 & & 7, & & 1,2 & & \\
\hline 4 & 3 & 1 & & 8, & & 1,1 & & \\
\hline 5 & 4 & 1 & & $\overline{9}$, & & 1,2 & & \\
\hline 6 & 5 & 1 & & 10 & & 1,2 & & \\
\hline 7 & 6 & $\overline{1}$ & & 11 & & 1,1 & & \\
\hline 8 & 7 & $\overline{1}$ & & $\begin{array}{c}13 \\
\end{array}$ & & 1,2 & & \\
\hline 9 & 8 & 1 & & $\begin{array}{l}14 \\
\end{array}$ & & 1,1 & & \\
\hline 10 & 9 & 1 & & 15 & & 1,1 & & \\
\hline 11 & 10 & 1 & & 16 & & 1,1 & & \\
\hline 12 & 11 & 1 & & 17 & & 1,1 & & \\
\hline 13 & 12 & $\overline{1}$ & & $\begin{array}{l}18 \\
\end{array}$ & & 1,1 & & \\
\hline & & & & & & & & \\
\hline & & & & & & & & \\
\hline & & & & & & & & \\
\hline
\end{tabular}

Feito por: $\quad$ Calle J. A. e Alfaro M. A.

\begin{tabular}{|l|c|}
\hline Profundidade do furo $[\mathrm{cm}]:$ & 90 \\
\hline Raio do furo[cm]: & 3 \\
\hline
\end{tabular}

Leituras para o $2^{\circ}$ estágio $\left(\mathrm{H}_{2}\right)$ de $10 \mathrm{~cm}$

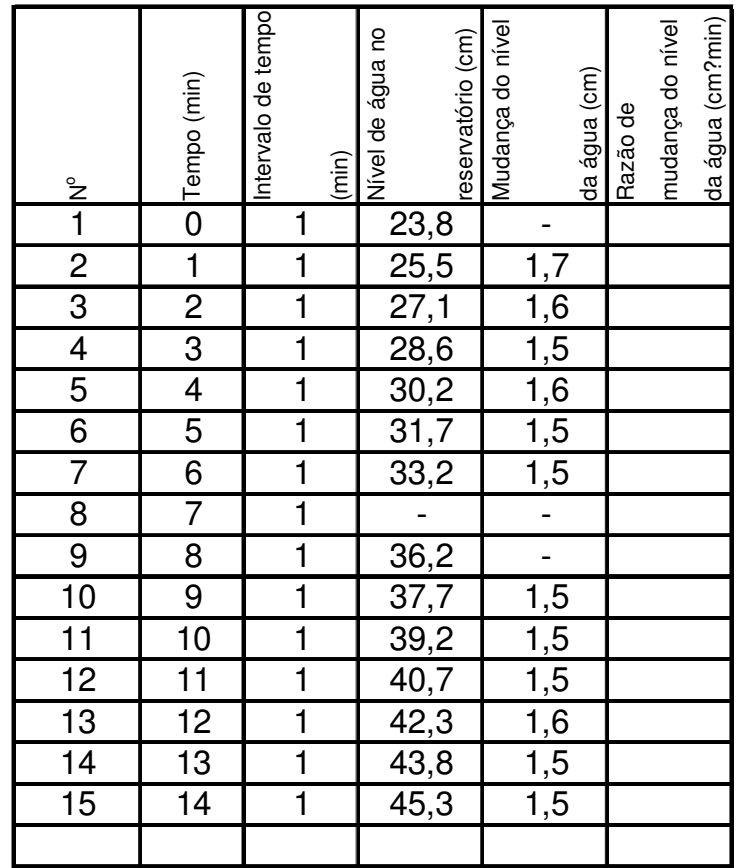

$\mathrm{Ri}$, razão de fluxo a régime constante, apartir de $\mathrm{R}$ em três consecutivos tempos de intervalos iguais.

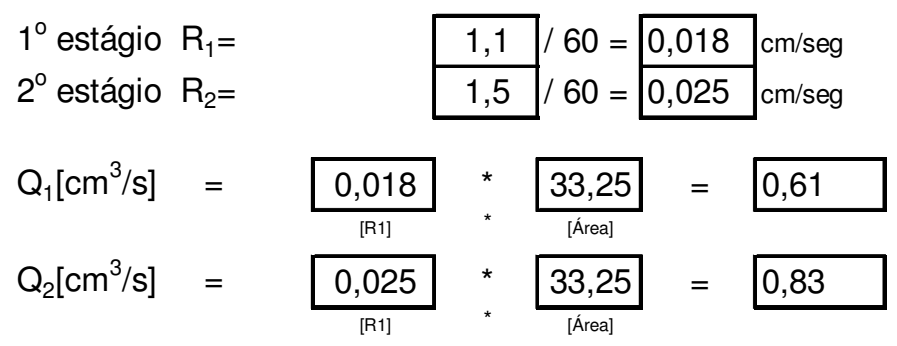

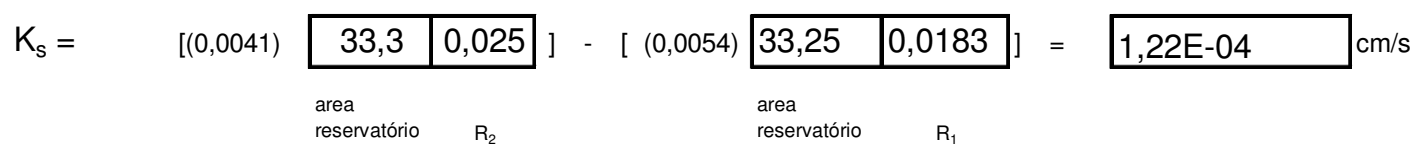

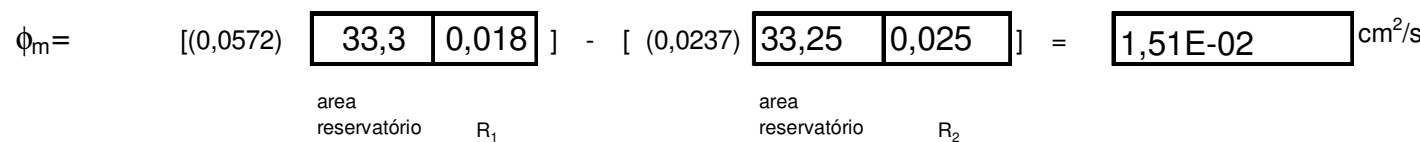

$\alpha=0,00012, \quad 0,015=0,0081 \mathrm{~cm}^{-1}$

NOTA: Os resultados de $K_{\mathrm{fs}}, \phi_{\mathrm{gm}}$ e $\alpha$, foram determinados com as formulas do manual do aparelho. 
b) Local de amostragem AI3

Data Maio / 1999

\begin{tabular}{|ll|l|}
\hline Ambos reservatórios $(\mathrm{X})$ & $\mathrm{cm}^{2}$ & 35,39 \\
\hline Reservatório interno $(\mathrm{Y})$ & $\mathrm{cm}^{2}$ & 2,14 \\
\hline
\end{tabular}

Leituras para o $1^{\circ}$ estágio $\left(\mathrm{H}_{1}\right)$ de $5 \mathrm{~cm}$.

\begin{tabular}{|c|c|c|c|c|c|c|}
\hline z & 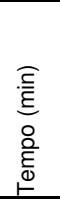 & 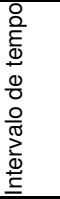 & 를 & 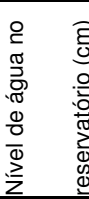 & 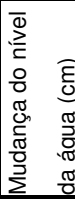 & 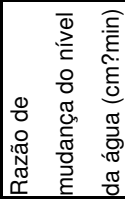 \\
\hline 1 & 0 & & & 4,1 & 0,8 & \\
\hline 2 & 1 & & & 4,9 & - & \\
\hline 3 & 2 & & & 5,5 & 0,6 & \\
\hline$\overline{4}$ & 3 & & & 6,2 & 0,7 & \\
\hline 5 & 4 & & & 6,9 & 0,7 & \\
\hline$\overline{6}$ & 5 & & & 7,6 & \begin{tabular}{|l}
0,7 \\
\end{tabular} & \\
\hline 7 & 6 & & & 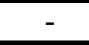 & - & \\
\hline 8 & 7 & & & 9,0 & - & \\
\hline 9 & 8 & & & 9,6 & \begin{tabular}{|l|}
0,6 \\
\end{tabular} & \\
\hline 10 & 9 & & & 10,3 & 0,7 & \\
\hline 11 & 10 & & & 11,0 & \begin{tabular}{|l|}
0,7 \\
\end{tabular} & \\
\hline 12 & 11 & & & 11,7 & 0,7 & \\
\hline 13 & 12 & & & 12,3 & 0,6 & \\
\hline 14 & 13 & & & 13,0 & \begin{tabular}{|l}
0,7 \\
\end{tabular} & \\
\hline 15 & 14 & & & 13,7 & \begin{tabular}{|l|l}
0,7 \\
\end{tabular} & \\
\hline & & & & & & \\
\hline
\end{tabular}

Feito por: Calle J. A. e Alfaro M. A.

\begin{tabular}{|l|r|}
\hline Profundidade do furo $[\mathrm{cm}]:$ & 90 \\
\hline Raio do furo[cm]: & 3 \\
\hline
\end{tabular}

Leituras para o $2^{\circ}$ estágio $\left(\mathrm{H}_{2}\right)$ de $10 \mathrm{~cm}$.

\begin{tabular}{|c|c|c|c|c|c|c|}
\hline iz & 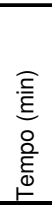 & 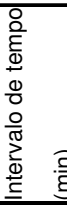 & 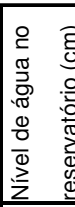 & 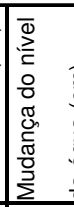 & 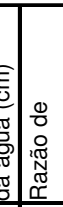 & 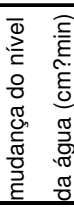 \\
\hline 1 & 0 & 1 & 18,2 & - & & \\
\hline 2 & 1 & 1 & - & - & & \\
\hline 3 & 2 & 1 & 20,1 & - & & \\
\hline 4 & 3 & 1 & 21,1 & - & & \\
\hline 5 & 4 & 1 & 22,1 & 1 & & \\
\hline 6 & 5 & 1 & 23,1 & 1 & & \\
\hline 7 & 6 & 1 & 24,1 & 1 & & \\
\hline 8 & 7 & 1 & 25,1 & 1 & & \\
\hline 9 & 8 & 1 & 26,1 & $\overline{1}$ & & \\
\hline 10 & 9 & 1 & 27,1 & 1 & & \\
\hline 11 & 10 & 1 & 28,1 & 1 & & \\
\hline & & & & & & \\
\hline & & & & & & \\
\hline & & & & & & \\
\hline & & & & & & \\
\hline & & & & & & \\
\hline
\end{tabular}

$\mathrm{Ri}$, razão de fluxo a régime constante, apartir de $\mathrm{R}$ em dois consecutivos tempos de intervalos iguais.

$1^{\circ}$ estágio $R_{1}=$

$2^{\circ}$ estágio $R_{2}=$

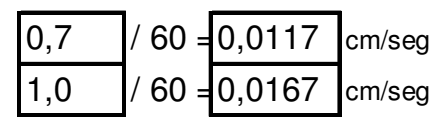

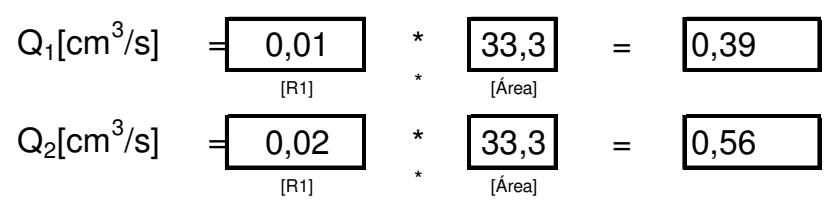

$\mathrm{K}_{\mathrm{s}}=[(0,0041)$

$\left.\begin{array}{|l|l|}\hline 33,3 & 0,017\end{array}\right]-[(0,0054) \quad 33,2$

\begin{tabular}{|l|l|}
\hline 33,25 & 0,0117 \\
\hline
\end{tabular}$=1,76 \mathrm{E}-04 \mathrm{~cm} / \mathrm{s}$

area
reservatório $\quad R_{2}$

reservatório $\quad R_{1}$

$\phi_{\mathrm{m}}=[(0,0572)$

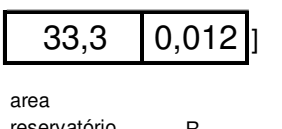

- $[(0,0237)$

\begin{tabular}{|l|l|}
\hline 33,25 & 0,0167 \\
\hline
\end{tabular}

$=9,09 \mathrm{E}-03 \mathrm{~cm}^{2} / \mathrm{s}$

reservatório $\quad R_{1}$

area

reservatório $\quad R_{2}$

$\alpha=\frac{0,0002}{\mathrm{~K}_{\mathrm{fs}}} / \frac{0,009}{\phi_{\mathrm{m}}}=0,0193 \mathrm{~cm}^{-1}$

NOTA: Os resultados de $\mathrm{K}_{\mathrm{fs}}, \phi_{\mathrm{gm}}$ e $\alpha$, foram determinados com as formulas do manual do aparelho. 
ANEXO E - CARACTERÍSTICAS DOS CORPOS DE PROVA DOS ENSAIOS TRIAXIAIS REALIZADOS. 
a) Corpos de prova dos ensaios triaxiais CD, com saturação por contra pressão.

\section{$\underline{\text { Local de amostragem AII }}$}

\begin{tabular}{|c|c|c|c|c|c|c|c|c|c|}
\hline $\mathbf{C P}$ & $\mathbf{w}_{\mathbf{o}}(\boldsymbol{\%})$ & $\boldsymbol{\rho}$ & $\boldsymbol{\rho}_{\mathbf{s}}$ & $\boldsymbol{\rho}_{\mathbf{d}}$ & $\mathbf{e}$ & $\mathbf{S}(\boldsymbol{\%})$ & $\mathbf{w}_{\mathbf{f}}(\boldsymbol{\%})$ & $\mathbf{S}_{\mathbf{f}}(\boldsymbol{\%})$ & File \\
\hline CP1 & 21,24 & 1,51 & 2,84 & 1,25 & 1,28 & 47,12 & 33,8 & 74,98 & a5rup \\
\hline CP2 & 21,00 & 1,58 & 2,84 & 1,31 & 1,17 & 50,76 & 32,9 & 79,52 & a1rt8 \\
\hline CP3 & 21,50 & 1,60 & 2,84 & 1,32 & 1,16 & 52,79 & 30,0 & 73,66 & a1rt1 \\
\hline CP4 & 22,00 & 1,65 & 2,84 & 1,35 & 1,10 & 56,81 & 26,7 & 68,94 & cd50b \\
\hline CP5 & 21,40 & 1,62 & 2,84 & 1,33 & 1,13 & 53,87 & 32,8 & 82,56 & cd100 \\
\hline CP6 & 21,23 & 1,61 & 2,84 & 1,33 & 1,14 & 52,96 & 33,0 & 82,32 & cd150 \\
\hline
\end{tabular}

\section{$\underline{\text { Local de amostragem AI2 }}$}

\begin{tabular}{|c|c|c|c|c|c|c|c|c|c|}
\hline CP & $\mathbf{w}_{\mathbf{o}}(\boldsymbol{\%})$ & $\boldsymbol{\rho}$ & $\boldsymbol{\rho}_{\mathbf{s}}$ & $\boldsymbol{\rho}_{\mathbf{d}}$ & $\mathbf{e}$ & $\mathbf{S}(\boldsymbol{\%})$ & $\mathbf{w}_{\mathbf{f}}(\boldsymbol{\%})$ & $\mathbf{S}_{\mathbf{f}}(\boldsymbol{\%})$ & $\mathbf{F i l e}$ \\
\hline CP7 & 18,13 & 1,82 & 2,89 & 1,54 & 0,88 & 59,83 & 27,1 & 89,43 & a1rt6 \\
\hline CP8 & 18,18 & 1,87 & 2,89 & 1,58 & 0,83 & 63,58 & 26,5 & 92,67 & a6rt4 \\
\hline CP9 & 18,13 & 1,78 & 2,89 & 1,51 & 0,92 & 57,08 & 27,2 & 85,63 & a2rt6 \\
\hline CP10 & 18,13 & 1,71 & 2,89 & 1,45 & 1,00 & 52,58 & 27,1 & 78,65 & a3rt6 \\
\hline CP11 & 18,13 & 1,83 & 2,89 & 1,55 & 0,87 & 60,53 & 31,4 & 104,82 & cdB50 \\
\hline CP12 & 18,14 & 1,77 & 2,89 & 1,50 & 0,93 & 56,43 & 28,2 & 87,73 & cdB100 \\
\hline CP13 & 18,13 & 1,73 & 2,89 & 1,46 & 0,97 & 53,83 & 25,8 & 76,60 & cdB150 \\
\hline
\end{tabular}


b) Corpos de prova dos ensaio triaxiais não drenados (UU), em corpos de prova na umidade natural

$\underline{\text { Local de amostragem AII }}$

\begin{tabular}{|c|c|c|c|c|c|c|c|}
\hline $\mathbf{C P}$ & $\mathbf{w}_{\mathbf{o}}(\boldsymbol{\%})$ & $\boldsymbol{\rho}$ & $\boldsymbol{\rho}_{\mathbf{s}}$ & $\boldsymbol{\rho}_{\mathbf{d}}$ & $\mathbf{e}$ & $\mathbf{S}(\boldsymbol{\%})$ & File \\
\hline CP1 & 21,40 & 1,58 & 2,84 & 1,30 & 1,18 & 51,41 & a1uu \\
\hline CP2 & 21,60 & 1,61 & 2,84 & 1,32 & 1,14 & 53,58 & a2uu \\
\hline CP3 & 21,90 & 1,62 & 2,84 & 1,33 & 1,14 & 54,70 & a3uu \\
\hline CP4 & 21,60 & 1,63 & 2,84 & 1,34 & 1,12 & 54,84 & uu5005 \\
\hline CP5 & 21,70 & 1,57 & 2,84 & 1,29 & 1,20 & 51,29 & auu100 \\
\hline CP6 & 21,64 & 1,61 & 2,84 & 1,32 & 1,15 & 53,64 & uu15005 \\
\hline
\end{tabular}

$\underline{\text { Local de amostragem AI2 }}$

\begin{tabular}{|c|c|c|c|c|c|c|c|}
\hline $\mathbf{C P}$ & $\mathbf{w}_{\mathbf{o}}(\boldsymbol{\%})$ & $\boldsymbol{\rho}$ & $\boldsymbol{\rho}_{\mathbf{s}}$ & $\boldsymbol{\rho}_{\mathbf{d}}$ & $\mathbf{e}$ & $\mathbf{S}(\boldsymbol{\%})$ & File \\
\hline CP7 & 17,60 & 1,84 & 2,89 & 1,56 & 0,85 & 60,05 & auu53 \\
\hline CP8 & 17,82 & 1,84 & 2,89 & 1,56 & 0,85 & 60,55 & au100 \\
\hline CP9 & 18,20 & 1,80 & 2,89 & 1,52 & 0,90 & 58,59 & a6uu7 \\
\hline CP10 & 18,14 & 1,79 & 2,89 & 1,52 & 0,91 & 57,77 & abuu50 \\
\hline CP11 & 18,13 & 1,78 & 2,89 & 1,51 & 0,92 & 57,08 & abuu100 \\
\hline CP12 & 18,15 & 1,77 & 2,89 & 1,50 & 0,93 & 56,46 & abuu150 \\
\hline
\end{tabular}


c) Corpos de prova, ensaio triaxial com controle de sucção.

\section{Local de amostragem AII, Bloco 2}

\begin{tabular}{|c|c|c|c|c|c|c|c|c|c|}
\hline $\mathbf{C P}$ & $\mathbf{w}_{\mathbf{o}} \mathbf{( \% )}$ & $\boldsymbol{\rho}$ & $\boldsymbol{\rho}_{\mathbf{s}}$ & $\boldsymbol{\rho}_{\mathbf{d}}$ & $\mathbf{e}$ & $\mathbf{S}(\boldsymbol{\%})$ & $\mathbf{w}_{\mathbf{f}}(\boldsymbol{\%})$ & $\mathbf{S}_{\mathbf{f}}(\boldsymbol{\%})$ & File \\
\hline 1 & 17,65 & 1,55 & 2,84 & 1,32 & 1,15 & 43,61 & 18,34 & 45,31 & s30 \\
\hline 2 & 17,74 & 1,51 & 2,84 & 1,28 & 1,21 & 41,63 & 18,10 & 42,47 & ai 250 \\
\hline 3 & 17,24 & 1,50 & 2,84 & 1,28 & 1,21 & 40,35 & 18,02 & 42,16 & as3 \\
\hline 4 & 17,71 & 1,52 & 2,84 & 1,29 & 1,20 & 41,81 & 17,81 & 42,04 & s75 \\
\hline 5 & 17,74 & 1,54 & 2,84 & 1,31 & 1,17 & 42,99 & 16,35 & 39,63 & as 100 \\
\hline 6 & 17,54 & 1,49 & 2,84 & 1,27 & 1,24 & 40,25 & 16,53 & 37,93 & as4 \\
\hline 7 & 17,62 & 1,50 & 2,84 & 1,28 & 1,23 & 40,80 & 15,81 & 36,60 & as5 \\
\hline 8 & 17,65 & 1,54 & 2,84 & 1,31 & 1,17 & 42,84 & 15,35 & 37,26 & as6 \\
\hline
\end{tabular}




\section{REFERÊNCIAS BIBLIOGRÁFICAS}

ABRAMENTO, M. (1988) Resistência ao cisalhamento de solos não saturados: Considerações teóricas e estudo experimental sobre solo coluvionar das encostas da serra do mar, dissertação de Mestrado, Escola Politécnica da USP, 1988.

ALONSO, E. E., GENS, A \& HIGHT, D.W. (1987). Special problems soils. General report. In: Europeam Conference on soils mechanics and Foundation Engineering, 9, Dublin, 1987. Proceedings. Rotterdam, A Balkema p. 5.1-5.6

ASAOKA, A., MATSUO, M. 1979. Bayasian approach to inverse problem in consolidation and its application to settlement prediction. Proc. $3^{\text {rd }}$ Int. Conf. On Numerical Methods in Geomechanics, Aachen.

BARATA, F.E. (1969) Landslides in the tropical region of Rio de Janeiro. Procedings, $7^{\text {th }}$ International Conference on Soil Mechanics and Foundation Engineering, México City, Vol. 2, pp. 507-516.

BAVER, L.D., GARDNER, W.H. \& GARDNER, W.R. (1972) Soils Physics. 4 ed. London, Inc., 1972. Cap. 7-9

BELIVEAU, J.G. (1976). Identification of viscous damping in structures from model information. J. Appl. Mech. 98:335-339.

BELL J.M. (1968) General slope stability and analysis. Jnl. Soil Mech. Fdns. Div. Am. Soc. Civ. Engrs. 94, SM6, 1253-1270.

BISHOP A W (1955) The use of the slip circle in the stability analysis of slopes. Geotechnique, 5, pp. 7-17.

BISHOP, A.W. (1959), The principle of effective stress, Tek, Ukebl. 39.

BISHOP, A W., ALPAN, G E \& DONALD B I, (1960). Factors controlling the shear strength of partly satureted cohesive soils. In: Research Conference on Shear strength of cohesive soils, Bouder, 1960. Proceedings. American Society of Civil Engineers, 1960. P 503532.

BISHOP A W \& DONALD I B (1961). The experimental study of partly saturated soil in triaxial apparatus. In: International Conference on Soil Mechanics and Foundation Engineering 5, Paris, 1961 Proceding p13-21.

BISHOP, A W. \& HENKEL, D.J. (1962), The measurement of Soil Properties in The Triaxial Test (2da edition). Edward Arnold, london, 236p. 
BISHOP, A W. \& MORGENSTERN N.E. (1960), Stability coefficient for earth slopes. Geotechnique, 10 No 4, 129-150.

BLIGHT, G.E. BRACKLEY I.J. \& VAN HCESDEM A (1970): Landslides at Amsterdanhock and Bethlehem - an examination of the mechanics of stiff finued clays, The Civil Engineer in South Africa, June pp. 129-140.

BLIGHT, G.E. (1987): Lowering of the groundwater by deep rooted vegetation, Procedings, $9^{\text {th }}$ Europeam Conference on Soil Mechanics and Foundation Engineering, Dublin, Ireland, 1:285-288.

BLIGHT, G.E. (1997): Case histories of shear strength-controlled aspects of residual soils, Mechanical of residual soils, pp. 221-237.

BOONSINSUK P. \& YONG, R.N. SIU, S.K.H. (1982) Analysis of Hong Kong residual soil slopes, Engineering and Constructions in tropical and residual soil, ASCE Geotechnical Engineering Division, Honolulu, Hawai, 1982, pp. 463-482.

BRAND, E.W. (1982) Analysis and design in residual soil, Engineering and Construction in Tropical and Residual soils, ASCE, Geotech. Div. Spec. Conf., Honolulu, Hawai: 89-143.

BRAND, E.W. (1985) Geotechnical Engineering in Tropical Residual soil, $1^{\text {st }}$ International Conference on Geomechanics in tropical Lateritic and Saprolitic Soils, Brasilia, 1985, Vol. 3, pp23-99.

BRAND E.W. PREMCHITT J. \& PHILLIPSON, H.B. (1984). Relationship between rainfall and landslides in Hong Kong. Proc. $4^{\text {th }}$ International Symposium on Landslides, Toronto, Vol. 1, pp. 377-384. (Discussium, Vol. 3 in press).

BRAND, E.W. \& PHILLIPSON, H.B. (1985a): Review of International practice for the sampling and testing of residual soil. Sampling and Testing for Residual Soil: A review for International Practice, edited by E.W. Brand \& H.B. Phillipson, pp7-21. Scorpion Press, Hong Kong.

BRESLER, E. (1978) Analysis of trickle irrigation with application to design problems., Irrig. Sci., v.1, pp. 3-17.

BROOKS, R. H. \& COREY, A T. (1966) Properties of porous media affecting fluid flow. Journal of the Irrigation and Drainage Division. Proceding of the American Society of the Civil Engineers, New York, 92(IR2): 61-88, June 1966.

BRUTSAERT, W. (1968) the permeability of a porous medium determined from certain probability laws for pore size distribution. Water Resources Research, Washington, 4(2): 425-434, April 1968. 
CACHAPUZ, F.G.M. (1978) Estabelecimento de parâmetros geotécnicos para análise de estabilidade de taludes de cortes a serem executados em terrenos virgens. In Anais do 2do Congresso Brasileiro de Geologia de Engenharia, ABGE, Vol.1, São Paulo p.157-172

CAMPBELL, J. D. (1973). Pore Pressure and Volume Changes in Unsatured Soils. $\mathrm{Ph} . \mathrm{D}$. dissertation, Univ. of Illinois at Urbana-Champaign, 144pp.

CAMPBELL, R.H. (1975) Soil Slips, debris flows, and rainstorms in Santa Monica mountains and vicinity, Southern California. US Geological Survey, Proffesional Paper 851, $55 \mathrm{p}$.

CAMPBELL G S \& GEE G W., (1986). Water potencial: miscellaneous methods. In: KLUTE, A ed. Methods of Agronomy, Inc., Soil Science Society of America, Inc., 1986. Cap. 25 p.619-633.

CAMPOS, T.P.M. (1994), Equipamentos e técnicas para determinação da sucção no campo. Anais II Simp. Solos não Saturados, Recife - PE pp. 9-18.

CARLSTRON FILHO, C. \& SALOMÃO F.X. de T. (1976), Experiência acumulada em estudos geológicos-geotécnicos de estabilidade de taludes em dois trechos ferroviários no Rio Grande do Sul. In: ler Congresso de Geologia de Enghenharia, ABGE, vol.1, Rio de Janeiro, pp. 293-305.

CARRARA, A. (1983). Multivariete models for landslide hazard evaluation. Mathematical Geology, Vol. 15, pp. 403-426.

CARSON, M.A (1969) Models of hillslope development under mass failure. Geographical Analysis, Vol. 4, pp. 76-100.

CHANDLER R J CRILLY M.S. \& MONTGOMERY SMITH H G. (1992). A lowcost method of assessing clay desiction of the institution of civil Eng. Vol 92 N0 2.

CHANDLER R J \& GUTIERRES C I (1986). The filter paper method of suction measurement. Geotechnique, London 36(2): 265-268.

CHILDS, E. C., COLLIS-GEORGE, N. (1950) The permeability of porous materials. Procedings of the Royal Society, Ser. A 201:392-405.

CHING, R.K.H. \& FREDLUND D.G. (1983): Some difficulties associated with the limit equilibrium method of slices. Canadian Getechnical Journal, Vol.20, pp661-672.

CHUGAEV, R.R. (1964) Stability analysis of Earth slopes. USSR All Union Scientific Research Institute of Hidraulic Engineering, 1964. (Translated from Russian, Israel Program for Scientific Translation, Jerusalem, Israel, 1966).

COREY, A T. (1957) Measurement of water and air permeability in unsatured soil. Proceding of the Soil Science Society of America, Madison, 21: p. 7-10. 
CRONEY D. \& COLEMAN J.D. (1961) Pore pressure and suction in soil, in Proc. Conf. Porre Pressure and Suction in Soils. London: Butterworths.

DA COSTA NUNES, A J. (1969) Landslides in soils of decomposed rock due to intense rainstorm, $7^{\text {th }}$ International Conference on Soil Mechanics and Foundation Engineering, México 2: 547-554, 1969.

DANIEL, D.E. \& STEPHEN, J.T. (1994) Hidraulic conductivity assesment of unsatured soils. ASTM, STP 1142, Daniel, D.E. \& Trautwein, S.J. Eds., Americam Society for Testing and Material, p. 184-223.

DAVIDSON, J.M., STONE, L.R., NIELSEN, D.R. \& LARUE, M.E. (1969) Field measurement and use of soil-water properties. Water Resources Research, 5: 1312-1321.

DEERE, D.U \& PATTON F.D. (1971) Slope stability in residual soils. Panamericam conference on soil mechanics and Foundation Engineering 4, Proceding. ASCE Vol. 1, pp. 87-170.

DELAGE, P, SURAJ DE SILVA, G P R \& DE LAURE E., (1987), Un noveal appareil triaxial pour les sols nonsaturés. In: Europeam Conference on Soil Mechanics and Foundation Engineering, 9., Dublin, 1987. Procedings. Rotterdam, A A Balkema. p25-28.

DRUMRIGHT E.E. \& NELSON J.D. (1995) The shear strength of unsatured tailing sands. Proc. of $I^{\text {st }}$ Int. Conf. On Unsatured Soils. Paris.

DUNCAN, J.M. (1980): The accuracy of equilibrium methods of slope stability analysis. Engineering Geology, Vol.16, pp5-17.

DUNCAN, J.M. \& WRIGHT, S.G. (1980): the accuracy of equilibrium methods of slopes stability analysis. Proceeding, International Symposium on Landslides, New Delhi, Vol. 1 pp.247-254.

ELRICK, D.E. REYNOLDS, W.D. \& TAN, K.A (1989) Hydraulic conductivity measurements in the unsatured zone using improved well analysis. Groundwater Monitoring Review. Vol.9, pp. 184-193.

ESCARIO V. (1988) Formulaciones para la definición de la resistencia a esfuerzo cortante de los suelos parcialmente saturados. Ingenieria Civil N ${ }^{\circ} 68$, CEDEX.

ESCARIO V. \& JUCA J.F.T. (1989) Strength and deformation of partly saturated soils. XII ICSMFE, Rio de Janeiro.

ESCARIO, V. \& SAEZ J. (1986) The shear strength of partly satured soils. Geotechnique 36 (3).

EYLES, R.J. (1979) Slip triggering rainfalls in Wellington city, New Zeland. New Zeland, Journal of Science, Vol. 22 pp. 117-121 
FAWCETT G. \& COLLIS-GEORGE N. (1967) A Filter-Paper Method for Determinig the Moisture Characteristics of Soil, Australian J. Exp. Agriculture and Animal Husbandry, vol. 7.

FELLENIUS W. (1936) Calculation of the stability of earth dams. Proc. $2^{\text {nd }}$ Congrese on large Dams. 4, pp. 445-463.

FONSECA E.C. (1991) Ensaio de cisalhamento direto com sucção controlada em solos não saturados, Tese de Mestrado, DEC/PUC - Rio.

FREDLUND, D.G. \& KRAHN, J. (1977): Comparison of slope stability methods of analysis. Canadian Geotechnical Journal, Vol.14 pp429-439.

FREDLUND, D. G., MORGERSTERN, N. R. \& WIDGER R A, (1978). The shear strength of Unsatured Soils. Canadian Geotechnical Journal., 15(3): 313-321, August 1978.

FREDLUND D.G., KRAHN J. \& PUFAHL D.E. (1981): The relationship between limit equilibrium slope stability methods. Procedings, $10^{\text {th }}$ International Conference on Soil Mechanics and Foundation Engineering, Stockholm, Vol.3 pp409-416.

FREDLUND D.G., (1984): Analytical methods of slope stability analysis. Procedings, $4^{\text {th }}$ International Symposium on Landslides, Toronto, Vol.1, pp.229-250.

FREDLUND, D. G., RAHARDJO J, H. \& GAN, J. K. M. (1987). Non-linearity of strength envelope for unsatured soils. Proc. Int. Conf. On Exp. Soils. New Dehli, 1987.

FREDLUND, D. G. \& RAHARDJO, H. (1993). Soil Mechanics for unsaturated soils. New York, John Wiley \& Sons, Inc. 1993.

FREDLUND, D. G., XING A, \& HUANG, S. (1994). Prediction the permeability funtions for unsatured soil using the soil water characteristics curve, Canadian Geotechnical Journal, Vol. 31, No 4, pp. 533-546, 1994.

FULFARO V.J. GAMA JÚNIOR E. SOARES P.C. (1980), Revisão estratigráfica da Bacia do Parana, Relatorio Paulipetro Consorcio CESP/IPT - 008180, São Paulo.

GAIOTO, N. \& QUEIROZ, R. (1993). Taludes naturais em solos. Solos do interior de São Paulo. ABMS/EESC/USP. pp. 207-242. 1993.

GAMA C.D. da (1984) Métodos computacionais de projetos de taludes em mineração. Tese apresentada na Escola de Engenharia de São Carlos-USP, para defesa de livre docência, São Carlos-SP, 171p.

GAN J.K. \& FREDLUND D.G. (1995) Shear strength behavior of two saprolitic soils. Proc. of $I^{\text {st }}$ Int. Conf. On Unsatured Soils. Paris.

GARDNER, W. R. (1958). Some steady-state solution of the unsatured moisture flow equation with application to evaporation from a water table, Soil Science, Baltimore, 85:228232. 
GATES, R.H. (1972). Slope analysis for explosive excavation. Proc., $13^{\text {th }}$ Symposium on Rock Mechanics, Urbana, Illinois, pp. 243-267.

GEO-SLOPE INTERNATIONAL, SEEP/W Manual-Version 3, Calgary, Alberta, Canada, 1993.

GEO-SLOPE INTERNATIONAL, SLOPE/W Manual-Version 3, Calgary, Alberta, Canada, 1993.

GIODA G. (1985). Some remarks on Back analysis and characterization problems in geomechanics, 5to International Conference on Numerical Methods in Geomechanics, Nagoya, 1985, Vol. 1, pp47-61.

GRANT, K. (1965) Terrain features of the Mt. Isa-Dajarra region and an assessment of their significance in relation to potential Engineering land use. CSIRO, Austrália, Soil Mechanics Section, Technical paper No 1, 110p \& 2 drgs.

GRANT, K. (1970) Terrain evaluation for Engineering purposes. Procedings, Symposium on Terrain Evaluation for Highway Engineering, Townsville, Austrália, pp. 81102.

GUIDICINI, G. \& NIEBLE C.M. (1976) Estabilidade de taludes naturais e de escavação, Ed. Universidade de São Paulo, 1976.

GUIDICINI, G. \& IWASA, O Y. (1977) Tentative correlation between “rainfall and landslides in a humid tropical environment Procedings, Symposium on Landslides and other Mass Movements, Prague. Bulletin of the International Association of Engineering Geology. No 16.

GULHATI, S.K. \& SATAJA, B.S. (1981) Shear Strength of partially saturated Soils ICSMFE, ID., Stokholm. Procedings, Vol. 1 pp. 609-612.

HAMBLIN, A P. (1981), Filter-paper method for routine measurement of field water potencial. Journal of Hydrology. Amsterdam, 53:355-360.

HILLEL, D. (1971) Soil Water-Physical principles and processes, New York, Academic Press, 1971, cap 1-5.

HO, D. Y. F. \& FREDLUND, D. G. (1982). A multistage triaxial test for unsatured soils. Geotechnique Testing Journal, ASTM, Philadelphia, 5(1/2): 18-25, March/June, 1982.

HOEK, E. (1972) Estimando a estabilidade de taludes escavados em minas a céu aberto. Tradução n 4, A.P.G.A., São Paulo, 58p

HOEK, E. \& BRAY, J. (1977). Rock Slope Engineering, Londo Institute of Mining and Metallurgy, $309 \mathrm{p}$.

IRMAY, S. (1954) On the hidraulic conductivity of unsatured soils. Transactions of the American Geophysical Union, 35(3): 463-467. 
JAMBU, N. (1954): Aplication of composite slip surfaces for stability analysis. Proceedings, Europeam Conference on the Stability of Earth Slopes, Stockholm, Vol. 3, p.4349.

JAMBU, N. (1973): slope Stability Computations. Embankment Dam Engineering (Casagrande Volume), edited by R. C. Hirschfeld \& S. J. Poulos, p.47-107. Wiley, New York.

JUCA, J.F.T. (1990). Comportamento de los suelos parcialmente saturados bajo succión controlada. Madrid, 1990, 346p, Doctorado, Universidad Politecnica de Madrid de España.

KANJI, M.A. INFANTI Jr. N. PINCA R.L. \& RESENDE M.A. (1976), Um exemplo de aplicação de ábacos de projeto no estudo da estabilidade de taludes. In: 1er Congresso Brasileiro de Geologia de Engenharia, ABGE, vol.1, Rio de Janeiro, pp. 281-292.

KENNEY, T.C. (1956) Na examination of the method of calculating the stability of slopes. MSc thesis, University of London.

KLUTE, A. \& DIRKSEN C., (1986). Hydraulic conductivity and diffusivity: laboratory methods. In: KLUTE, A, ed. Methods of soil Analysis. 2 ed. Madison, Americam Society of Agronomy, Inc., 1986. Cap. 26: pp. 635-656 and, Cap. 28, p.687.

KOOREVAAR, MENELIK G., \& DIRKSEN C. (1983) Element of Soil Physics. Amsterdam, The Netherlands: Elsevier.

KOVACS, G. (1981) Seepage Hydraulics. Elsevier. Amsterdam.

LANE, K.S. (1961): Field slope charts for stability studies. Procedings, $5^{\text {th }}$ International Conference on Soil Mechanics and Foundation Engineering, Paris, Vol. 2, pp. 651-655.

LEONG E.C. RAHARDJO H. DEUTSCHER M.S. \& QUAN C.N. (1998). Instrumentation and data acquisition system for the study of a residual soil slope at a remote site. $2^{\text {nd }}$ International Conference on Unsatured Soils, Beijing, China, Vol.1, pp. 383-388.

LIM, T.T. RAHARDJO, H. \& CHANGE M.F. (1996) Climatic Effects on Negative pore water Pressure in a residual Soil slope. $4^{\text {th }}$ Int. Conf. on tropical Soils, Kuala Lumpur, Malaysia 1:568-574.

LUMB, P. (1975). Slope failure in Hong Kong. Quarterly Journal of Engineering Geology. Vol.8 p.31-65.

LUMB, P. (1979) Statistics of natural disasters in Hong Kong, 1884-1976. Procedings, $3^{\text {rd }}$ international Conference on the Applications of Statistics \& Probability in Soil \& Structural Engineering, Sydney, Vol. 1 pp. 9-22.

LUTTON, R.J. (1970) Rock slope chart from empirical slope data. Trans. Society of Minig Engineers, AIME, vol. 247 pp. 160-162. 
MACHADO, S.L. (1998) Aplicação de conceitos de elastoplasticidade a solos não saturados, Tese de Doutoramento apresentada na Escola de Engenharia de São Carlos-USP.

MADEJ, J. (1971). On the accuracy of the simplified methods for the slope stability analysis. Archwm. Hidrotech. 18 No. 4, 581-595.

MARINHO F.A M. (1995). A técnica do papel filtro para medição de sucção, ler Encontro Sobre Solos não Saturados, Rio Grande do Sul, 1995.

MARSHALL, T.S \& HOLMES, J.M. (1981). Soil Physics, Cambridge, Cambridge University Press, 1981 cap. 1-4.

McQUEEN, I.S. \& MILLER, R.F. (1968) Calibration and evaluation of wide range gravimetric method for measuring moisture stress, Soil Science, Vol. 106, No 3, pp. 225-231.

MENCL, U. (1966). Mechanics of landslides with non circular slip surface with special reference to the Vaiont slide. Geotechnique 16(4): 329-337.

MILLER, R.J. \& LOW, P.F. (1963). Threehold gradient for water flow in clay system. Proceding of the Soil Science Society of America, Madison, 27: 605-609.

MORGENSTERN, N.R. \& PRICE, V.E. (1965): The analysis of the stability of general slip surfaces. Geotechnique, Vol. 15, pp79-83.

MORGENSTERN, N.R. \& SANGREY, D.W. (1978): Methods of stability analysis. Landslides: Analysis and Control, edited by R.L. Schuster \& R.J. Krizek, pp155-171. Transportation Research Board, Special Report 176, Washington D.C.

MULLER, L. (1964). The rockslide in the Vaiont Valley. Rock Mechanic and Engineering Geology II (3-4): 148-212.

NILSEN, T. TAYLOR, F.A. \& BRABB E.E. (1976): Recent landslides in Alameda County, California (1940-71): Na estimate of economic losses and correlations with slope, rainfall, and ancient landslide deposits. US Geological Survey, Bulletin 1398, 24p. \& 1 drg.

NONVEILLER, E. (1965) The stability analysis of slopes with a slip surface of general shape. Proc. $6^{\text {th }}$ Int. Conf. Soil Mech. Engin. Found. 2, 522-525.

PECK, R.B. (1969). Advantages and limitations of the observational method in applied soil mechanics, Geotechnique 19: 171-187.

PHILIP, J.R. (1985) Approximate analysis of the borehole permeameter in unsatured soil-water. Resources Research. Vol. 21, nº 7, pp. 1025-1033.

RANA M.H. \& BULLOCK W.D. (1969), The design of open pit mine slopes. Canadian Mining Journal. pp. 58-62.

REICHARDT, K. (1985). Processos de Transferencia no sistema solo-plantaatmosfera. Fund., Cargill, campinas, 466p. 
REYNOLDS, W.D. \& ELRICK, D.E. (1985). In situ measurement of field-saturated hydraulic conductivity, sorptivity and the $\alpha$-parameter using the Guelph permeameter. Soil Science, v.140,n.4,p.292-302, 1985.

REYNOLDS, W.D. \& ELRICK, D.E. (1983). A reexamination of the constant head well permeameter method for measuring satured hydraulic conductivity above the water table. Soil Science, v.136,n.4,p.250-268.

RICHARDS, B.G. (1931) Capillary conduction of liquids through porous medium. Physics, New York, 1, p. 318-333.

RICHARDS, B.G. (1974) Behavior of unsatured soils. In: LEE, I.K., ed. Soil Mechanic. New York, American Elsevier Publishing Company, Inc., cap 4.

RIJTEMA, P.E. (1965) An analysis of actual evapotranspiration. Agricultural Research Reports (Wageningen) No. 659.

ROHM,S.A. (1992). Resistência ao cisalhamento de um solo arenoso laterizado não saturado da região de São Carlos. Tese de Doutoramento, EESC - USP.

SAKURAI, S. (1983). Displacement measurements associated with the design of underground openings. Proc. Int. Symp. On Field Measurements in Geomechanics, Zurich.

SAKURAI, S. (1993). Back Analysis in Rock Engineering, Comprehensive Rock Engineering. Edit. John A Hudson. Imperial College of Science, Technology \& Medicine, London, UK. Vol. 4. pp. 543-570.

SANTOS A.R. dos (1976) Por menos ensaios e instrumentações e por uma maior observação da natureza. In: ler Congresso Brasileiro de Geologia de Engenharia, ABGE, vol.1, Rio de Janeiro, pp. 177-185.

SARMA, S.K. (1973): Stability analysis of embankments and slopes. Geotechnique, Vol23, pp423-433.

SCHUMM, S.A \& MOSELY, M.P. (Editors) (1973) Slope Morphology. (Benchmark Papers in Geology). Dowden, Hutchinson \& Ross Inc., Stroudsburg, Pennsylvania, 464p.

SCOOTER, D.R. CLOTHIER, B.E. \& HARPER, E.R. (1982). Measuring satured hidraulic conductivity and sorptivy using twin rings. Aust. Journal Soil Res. Vol. 20, pp. $295-$ 304.

SCOTT, R.F. (1963) Principles of soil mechanics, Massachusetts: Addison-Wesley.

SHUK T. (1965) Discussion on "some aspects of the safety factor in soil mechanics" by ${ }^{\text {a }}$ Langejan. Procedings, $6^{\text {th }}$ International Conference on Soil Mechanics and Foundation Engineering, Montreal, Vol. 2, pp.576-577.

SHUK. T. (1968). Un método sencillo de diseño para minimizar el costo de taludes en roca. Proc. $1^{\text {st }}$. Columbian Symposium on Eng. Geology, Bogota, Vol. 2, 17p. 
SMILES, D. E. BARNES, C. J. \& GARDNER, W.R. (1985). Water relations of saturated bentonite: some effects of temperature and solution salt concentration. Soil Science Society of America Journal, 49(1).

SOARES P.C. LANDIM P.M.B. FULFARO V.J. SOBREIRO NETO A.F. (1980), Ensaios de caracterização estratigráfica do cretáceo no Estado de São Paulo: Grupo Bauru Rev. Bras. Geoc., 10(3): 177-185 São Paulo.

SOILMOISTURE EQUIPAMENT CORP. (1986) Guelph Permeameter. OperatingInstructions, Soilmoisture manual, Rev. 8, pp. 1-25.

SPENCER, E. (1967): A method of analysis of the stability of embankments assuming parallel interslice forces. Geotechnique, Vol.17, pp11-26.

TAYLOR, D.W. (1937). Stability of earth slopes, Jorn. Boston Soc.. CE.

TAYLOR, D.W. (1948). Fundamentals of Soil Mechanics. New York, Willey, 1948.

TAYLOR D.K., HAWLEY, J.G. \& RIDDOLLS, B.W. (1977) Slope stability in Urban Development. New Zeland Geomechanics Society, and New Zeland Department of Scientific and Industrial Research, Wellington, 71p.

TAVENAS, F. LEBLOND, P. JEAN, P. \& LEROUEIL, S. (1983) The permeability of natural soft clays. Part I: methods of laboratory measurement. Canadian Geotechnical Journal, 20(4).

TEIXEIRA, R. S. (1996) Resistência ao cisalhamento de um solo arenoso compactado não saturado. Dissertação de Mestrado. EESC/UPS São Carlos, 1996.

TOPP, G.C. \& MILLER, E.E. (1966) Hysteretic misture characteristics and hydraulic conductivities for glass-bead media. Procceding of the Soil Science Society of America, Madison, 30:156-162.

VAN GENUCHTEN, M.T. (1980), A closed form equation for predicting the hydraulic conductivity of unsatured soils. Soil Sci. Soc.Am.J.,vol 44,n5, pp892-898

VARNES, D.J. (1978) Slope Movement. Types and Processes, in Lanslide. Analysis and Control, Special report 176, Nacional Academy of Sciences, Washington, D.

VAN LIER Q.J.; NETO D.D. (1991) Programa CURVARET versão 2,16, Departamento de Física e Metereologia, Departamento de Agricultura ESALQ-USP.

VILAR, O.M. (1997) Introdução a mecânica de solos não saturados. Notas de aula.

WHITMAN, R.V. \& BAILEY W.A.. (1967): Use of computer for slope stability analysis. Jnl. Soil Mech. Fdns. Div. Am. Soc. Civ. Engrs. 93, SM4, 475-498.

WHITMAN, R.V. \& MOORE, P.J. (1963): Thoughts concerning the mechanics of slope stability analysis. Proceding, 2da Panamerican Conference on Soil Mechanics and Foundation Engineering, Brazil, Vol. 1 pp.391-411. 
WIND. G.P. (1955) Field Experiment concerning capillary rise of moisture in heavy clay soil. Netherlands Journal of Agricultural Science.. 3: 60-69.

WOOD, D. M., (1979). The behavior of partly saturated soils: A review, CUED/D Soils/TR 691979.

WRIGHT S.G. "A study of slope stability and the undrained shear strength of clay shales" Thesis presented to the University of California, at Berkeley Calif. In 1969, in partial fulfillment of the requirements for the degree of Doctor of Philosophy.

WRIGHT, S.G., KULHAWY, F.H. \& DUNCAN, J.M. (1973): Accuracy of equilibrium slope stability analysis. Journal of the Soil Mechanics and Foundations Division, ASCE, Vol.99, pp.783-791.

YAMAGAMI T, UETA Y. \& JIANG J. C. (1997), A back analysis method for unsatured soil strength parameters, $2^{\text {nd }}$ Pan-American Symposium on Landslides, Vol. 1, Rio de Janeiro, p. 511-519.

YOUNG, S. (1972) Slopes. Longman, London, 295p. 